\title{
Total Synthesis of (+)-Nakadomarin A
}

\author{
Supporting Information
}

\author{
Ian S. Young and Michael A. Kerr* \\ The University of Western Ontario, Department of Chemistry, London, Ontario, Canada N6A 5B7
}

\section{Table of Contents}

General Experimental

Compounds 24 - Nakadomarin A

Spectra

Spectral Comparison of the Natural Product page $\mathrm{S}-2$

page $\mathrm{S}-2-\mathrm{S}-29$

page $\mathrm{S}-30-\mathrm{S}-105$

page $\mathrm{S}-105$ 


\section{Experimental}

\section{General}

Melting points were determined using a Gallenkamp melting point apparatus and are uncorrected. Infrared spectra were obtained as thin films on $\mathrm{NaCl}$ plates using a Bruker Vector 33 FT-IR instrument. NMR experiments were performed on Varian Mercury 400, Varian Inova 600 and Inova 400 instruments and samples were obtained in $\mathrm{CDCl}_{3}$ (referenced to $7.26 \mathrm{ppm}$ for ${ }^{1} \mathrm{H}$ and 77.0 for ${ }^{13} \mathrm{C}$ ) or Methanol- $\mathrm{d}_{4}$ (referenced to 3.30 for ${ }^{1} \mathrm{H}$ ). Coupling constants $(\mathrm{J})$ are in Hz. The multiplicities of the signals are described using the following abbreviations: $\mathrm{s}=$ singlet, $\mathrm{d}=$ doublet, $\mathrm{t}=$ triplet, $\mathrm{q}=$ quartet, $\mathrm{p}=$ pentet, $\mathrm{m}=$ multiplet, $\mathrm{br}=$ broad. High resolution mass spectra (HRMS) were obtained on a Finnigan MAT 8200 spectrometer at $70 \mathrm{eV}$. Optical rotations of the intermediates were recorded in cells of $10 \mathrm{~cm}$ path length using an Atago Polax-2L polarimeter. The optical rotation of Nakadomarin A was measured on a Perkin-Elmer 241 digital polarimeter.

All reactions were performed under an atmosphere of argon unless otherwise indicated. Toluene, tetrahydrofuran (THF), ether, N,N-dimethylformamide (DMF), and methylene chloride were dried and deoxygenated by passing the nitrogen purged solvents through activated alumina columns. All other reagents and solvents were used as purchased from Aldrich, Strem, Caledon or VWR. Reaction progress was followed by thin layer chromatography (TLC) (EM Science, silica gel $60 \mathrm{~F}_{254}$ ) visualizing with UV light, and the plates developed using acidic anisaldehyde, phosphomolybdic acid or basic potassium permanganate. Flash chromatography was performed using silica gel purchased from Silicycle Chemical Division Inc. (230-400 mesh). Preparative TLC was performed on glass backed $0.25 \mathrm{~mm}$ silica plates (Rose Scientific, silica gel $60 \mathrm{~F}_{254}$ ).

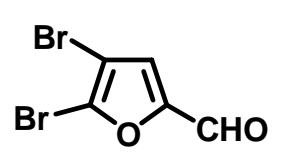

Compound 24a was prepared using the procedure of Chiarello, J.; Joullie, M. M. Tetrahedron 1988, 44, 41-8, with changes made to the purification procedure. Freshly distilled furfural $(20.00 \mathrm{~g}, 208.13 \mathrm{mmol})$ was added dropwise at $0{ }^{\circ} \mathrm{C}$ to Compound 24a aluminum chloride $(61.06 \mathrm{~g}, 457.90 \mathrm{mmol})$ over a two hour period with mechanical stirring. Bromine $(73.17 \mathrm{~g}, 457.90 \mathrm{mmol})$ was then added dropwise at $0{ }^{\circ} \mathrm{C}$ over a two hour period, after which stirring was discontinued and the reaction allowed to stand overnight. The reaction was quenched by carefully pouring the mixture into ice $(800 \mathrm{~mL})$ and then extracting the aqueous layer three times with ether. The combined organics were washed twice with saturated sodium bicarbonate, once with brine, and dried with $\mathrm{MgSO}_{4}$. The solvent was removed under reduced pressure to yield a red oil. In the above reference the product was purified by distillation, but heating led to a black tar and no product being recovered. Purification using column chromatography on silica (hexanes / ethyl acetate as eluent) yielded 24a (24.85 g, $97.81 \mathrm{mmol}, 47 \%, \mathrm{R}_{\mathrm{f}}=0.48,20 \%$ ethyl acetate in hexanes) as an orange oil. Less than $5 \%$ of what might be another bromination isomer is present.

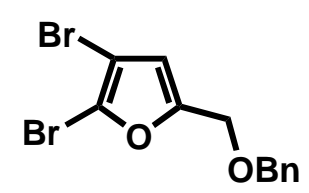

Compound 24b

Dibromoaldehyde 24a (14.50 g, $57.07 \mathrm{mmol})$ was dissolved in methanol (175 $\mathrm{mL}$ ) and cooled to $0{ }^{\circ} \mathrm{C}$. $\mathrm{NaBH}_{4}(2.16 \mathrm{~g}, 57.07 \mathrm{mmol})$ was added in four portions over 15 minutes. After 1 hour, water $(5 \mathrm{~mL})$ was added and the methanol removed under reduced pressure. The residual material was added to water (200 $\mathrm{mL})$ and $5 \% \mathrm{HCl}(20 \mathrm{~mL})$ and the aqueous layer extracted 3 times with ethyl 
acetate. The combined organics were washed with water and dried with $\mathrm{MgSO}_{4}$, and the solvent removed under reduced pressure. The resulting crude dibromoalcohol (13.61 g, 53.14 mmol, 94\%) was recovered as a red oil, and was of sufficient purity to be directly benzylated. THF (200 mL) was added to sodium hydride ( $2.70 \mathrm{~g}, 3.38 \mathrm{~g}$ of $80 \%, 112.50 \mathrm{mmol})$ that was washed with hexanes, and the resulting slurry cooled to $0{ }^{\circ} \mathrm{C}$. The crude dibromoalcohol from above $(13.61 \mathrm{~g}, 53.14 \mathrm{mmol})$ was added as a solution in THF (100 mL) via a dropping funnel, and once the addition was complete, the mixture was stirred for 30 minutes. Benzyl bromide (8.18 g, $51.51 \mathrm{mmol})$ dissolved in THF (100 mL) was added via cannula, and the mixture warmed to room temperature and stirred for 13 hours. Water (50 mL) was added and the THF removed under reduced pressure. Water (200 mL) was added and the aqueous phase extracted 3 times with ethyl acetate. The combined organics were washed with water, brine and then dried with $\mathrm{MgSO}_{4}$. Removal of the solvent under reduced pressure produced benzylated product $\mathbf{2 4 b}$ (15.53 g, $44.87 \mathrm{mmol}$, 84\%) as an orange oil which was not purified.

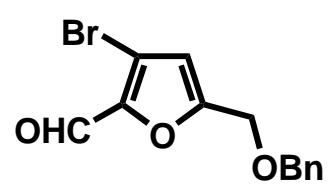

The procedure used is an adaptation from Zaluski, M-C., Robba, M., Bonhomme, M. Bull. Soc. Chim. Fr. 1970, 1838 for the preparation of a similar compound. $\mathrm{n}-\mathrm{BuLi}$ (21.70 $\mathrm{mL}$ of $1.6 \mathrm{M}$ in hexanes, $34.72 \mathrm{mmol})$ was added to anhydrous ether $(150 \mathrm{~mL})$ and the solution was cooled to $-78{ }^{\circ} \mathrm{C}$. A solution of Compound $24 \quad$ 24b (7.77 g, $22.45 \mathrm{mmol})$ in ether $(100 \mathrm{~mL})$ was added dropwise to the $\mathrm{n}-\mathrm{BuLi}$, and after addition was complete the mixture was stirred for 30 minutes at $-78{ }^{\circ} \mathrm{C}$. DMF $(1.98 \mathrm{~g}, 31.43$ $\mathrm{mmol})$ in ether $(100 \mathrm{~mL})$ was then added dropwise, and after addition was complete the reaction was warmed to room temperature over two hours, and then refluxed for 30 minutes. The reaction was quenched by the addition of water $(5 \mathrm{~mL})$, and then $5 \% \mathrm{HCl}(300 \mathrm{~mL})$ was added. The layers were separated and the aqueous extracted 3 times with ether. The combined organics were washed with water, dried with $\mathrm{MgSO}_{4}$ and the solvent removed under reduced pressure. Flash column chromatography on silica gel (hexanes / ethyl acetate as eluent) afforded 24 (3.41 g, $11.55 \mathrm{mmol}$, $51 \%)$ as a pale yellow oil. $\mathrm{R}_{\mathrm{f}}=0.42,20 \%$ ethyl acetate in hexanes; ${ }^{1} \mathrm{H}-\mathrm{NMR}\left(400 \mathrm{MHz}, \mathrm{CDCl}_{3}\right): \delta=$ 9.69 (s, 1H), 7.39-7.30 (m, 5H), 6.62 (s, 1H), 4.60 (s, 2H), 4.55 (s, 2H); ${ }^{13} \mathrm{C}$ NMR (100 MHz, $\left.\mathrm{CDCl}_{3}\right)$ : $\delta=176.0,158.4,147.6,136.9,128.5,128.0,127.8,114.7,113.3,73.0,63.9 ; \quad$ IR (thin film): 3119, 3032, 2856, 1679, 1575, 1520, 1454, 1352, 1274, 1209, 1094, 1033, 973, 794, 739, $699 \mathrm{~cm}^{-1}$; HRMS calc'd for $\mathrm{C}_{13} \mathrm{H}_{11} \mathrm{BrO}_{3}=293.9892$, found $=293.9887$.

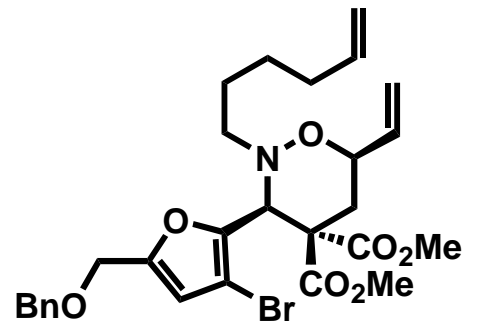

Compound 25

Aldehyde 24 (1.13 g, $3.81 \mathrm{mmol})$ and hydroxylamine 22 (0.44 g, 3.81 mmol) were added to toluene (30 mL) containing 4A molecular sieves. $\mathrm{Yb}(\mathrm{OTf})_{3} \bullet \mathrm{xH}_{2} \mathrm{O}(0.197 \mathrm{~g}, 0.318 \mathrm{mmol})$ was added and the mixture stirred for three hours, after which cyclopropane 23 (0.585 g, 3.17 $\mathrm{mmol}$ ) was added. The reaction was stirred at room temperature, and after 24 hours a small amount of cyclopropane remained, so additional hydroxylamine 22 (35 mg, $0.304 \mathrm{mmol}$ ) was added and the reaction stirred for 24 more hours. The reaction was then filtered through celite, and the filter cake washed with ether. The excess aldehyde $\mathbf{2 4}$ had a $\mathrm{R}_{\mathrm{f}}$ similar to the product, so the solvent was removed under reduced pressure and the residual material dissolved in methanol (30mL). $\mathrm{NaBH}_{4}$ (100 mg, $2.65 \mathrm{mmol}$ ) was added and after 30 minutes water (25 mL) was added and the methanol removed under reduced pressure. Ethyl acetate $(25 \mathrm{~mL})$ was added and the layers separated. The aqueous layer was extracted once with ethyl acetate and then twice with ether. The combine organics were washed with water, brine, dried with $\mathrm{MgSO}_{4}$ and the solvent removed under reduced 
pressure. The resulting crude material was purified by flash column chromatography on silica (hexanes / ethyl acetate as eluent) to yield cycloadduct 25 (1.52 g, $2.63 \mathrm{mmol}, 82 \%)$ as a colorless oil. Proton NMR indicates that there was approximately $8 \%$ of what might be the other diastereomer. This impurity is removed upon formation of 27. $\mathrm{R}_{\mathrm{f}}=0.48,25 \%$ ethyl acetate in hexanes; ${ }^{1} \mathrm{H}-\mathrm{NMR}$ (600 MHz, $\left.\mathrm{CDCl}_{3}\right): \delta=7.36-7.33(\mathrm{~m}, 4 \mathrm{H}), 7.31-7.28(\mathrm{~m}, 1 \mathrm{H}), 6.38$ (s, $\left.1 \mathrm{H}\right), 5.88$ (ddd, J = 16.8, 10.8, $6.0 \mathrm{~Hz}, 1 \mathrm{H}$ ), 5.83-5.76 (m, 1H), 5.35 (ddd, J = 18.0, 1.8, 1.2 Hz, 1H), 5.20 (ddd, J = 10.8, 2.4, $1.8 \mathrm{~Hz}$, 1H), 5.01 (s, 1H), 5.01-4.97 (m, 1H), 4.93 (ddd, J = 10.8, 1.8, 0.6 Hz, 1H), 4.52-4.38 (m, 5H), 3.84 (s, $3 \mathrm{H}), 3.54$ (s, 3H), 2.60-2.50 (m, 4H), 2.06-2.02 (m, 2H), 1.63-1.55 (m, 2H), 1.54-1.48 (m, 1H), 1.431.37 (m, 2H); ${ }^{13} \mathrm{C}$ NMR (150 MHz, $\left.\mathrm{CDCl}_{3}\right): \delta=169.2,168.1,153.2,147.0,138.8,137.7,136.5$, 128.3, 127.8, 127.7, 117.1, 114.3, 112.3, 103.1, 76.6, 71.7, 63.7, 58.0, 57.7, 54.8, 53.2, 52.7, 33.4, 31.4, 26.4, 26.1; IR (thin film): 2951, 2927, 2856, 1743, 1641, 1436, 1358, 1257, 1208, 1173, 1114, 1074, 1032, 990, 912, 828, 816, 739, $698 \mathrm{~cm}^{-1}$; HRMS calc'd for $\mathrm{C}_{28} \mathrm{H}_{34} \mathrm{BrNO}_{7}=575.1519$, found = 575.1511.

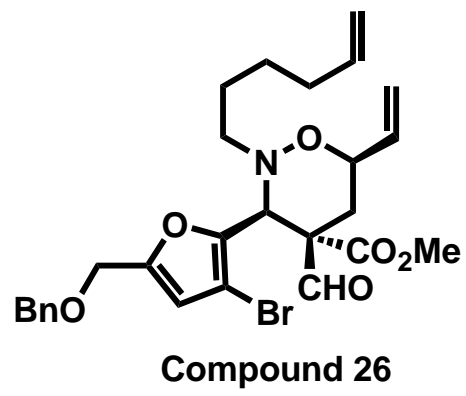

Cycloadduct 25 (300 mg, $0.521 \mathrm{mmol}$ ) was dissolved in methylene chloride $(60 \mathrm{~mL})$ and then cooled to $-78{ }^{\circ} \mathrm{C}$. DIBAL $(2.1 \mathrm{~mL}$ of $1.5 \mathrm{M}$ solution in toluene, $3.15 \mathrm{mmol}$ ) was added dropwise and the reaction stirred for 15 minutes, after which multiply eluted TLC showed complete consumption of the starting material. Methanol $(5 \mathrm{~mL})$ was then added slowly to quench the excess DIBAL, and the mixture stirred at $-78{ }^{\circ} \mathrm{C}$ for 20 minutes, after which it was removed from the dry ice bath and allowed to warm to room temperature. The reaction was then poured into $5 \% \mathrm{HCl}(20 \mathrm{~mL})$ and the layers separated. The aqueous layer was extracted 3 times with methylene chloride, and the combined organics washed with $5 \% \mathrm{HCl}$. The organic layer was dried with $\mathrm{MgSO}_{4}$, and the solvent removed under reduced pressure. The residual material was purified by flash column chromatography on silica gel (hexanes / ethyl acetate as eluent) to yield aldehyde 26 (276 mg, $0.505 \mathrm{mmol}, 97 \%$ ) as a yellow oil. $\mathrm{R}_{\mathrm{f}}=0.50,25 \%$ ethyl acetate in hexanes; ${ }^{1} \mathrm{H}-\mathrm{NMR}\left(400 \mathrm{MHz}, \mathrm{CDCl}_{3}\right): \delta=9.26(\mathrm{~s}, 1 \mathrm{H}), 7.35-7.31(\mathrm{~m}, 5 \mathrm{H}), 6.38(\mathrm{~s}, 1 \mathrm{H}), 5.93-5.84$ (m, 1H), 5.82-5.74 (m, 1H), 5.36 (d, J = 17.6 Hz, 1H), 5.21 (d, J = 10.8 Hz, 1H), 5.08 (s, 1H), 4.98 (dd, $\mathrm{J}=17.2$, $1.2 \mathrm{~Hz}, 1 \mathrm{H}), 4.93$ (d, J = 10.4 Hz, 1H), 4.53-4.43 (m, 5H), 3.87 (s, 3H), 2.60-2.48 (m, 2H), 2.38-2.33 (m, 2H), 2.06-2.01 (m, 2H), 1.62-1.48 (m, 3H), 1.43-1.36 (m, 2H); ${ }^{13} \mathrm{C}-\mathrm{NMR}$ (100 MHz, $\left.\mathrm{CDCl}_{3}\right): \delta=195.0,168.8,154.1,146.0,138.8,137.5,136.5,128.4,127.9,127.8,117.2,114.4,112.3$, 103.9, 76.6, 71.9, 63.7, 63.1, 57.3, 54.7, 53.3, 33.4, 28.4, 26.3, 26.0; IR (thin film): 3076, 3032, 2947, 2935, 2857, 1752, 1722, 1641, 1452, 1438, 1358, 1239, 1220, 1114, 1073, 1031, 996, 909, 809, 743, $698 \mathrm{~cm}^{-1}$; HRMS calc'd for $\mathrm{C}_{27} \mathrm{H}_{32} \mathrm{BrNO}_{6}=545.1413$, found $=545.1403$.

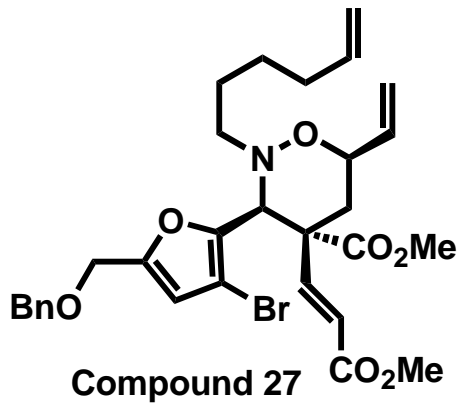

Trimethyl phosphonoacetate $(1.04 \mathrm{~g}, 5.69 \mathrm{mmol})$ was dissolved in THF (75 mL) and cooled in an ice bath. t-BuOK (0.638 g, $5.69 \mathrm{mmol})$ was added and the slurry was stirred for 10 minutes. Aldehyde 26 (2.07 g, $3.79 \mathrm{mmol})$ in THF (75 mL) was then added slowly via cannula, and TLC indicated complete consumption of the starting material after 13 hours. Water $(20 \mathrm{~mL})$ was added, and the THF removed under reduced pressure. To the resulting residue was added water $(50 \mathrm{~mL}), 5 \% \mathrm{HCl}$ $(10 \mathrm{~mL})$ and ethyl acetate $(50 \mathrm{~mL})$. The layers were separated, and the 
aqueous washed 3 times with ethyl acetate. The combined organics were washed with water, brine and dried with $\mathrm{MgSO}_{4}$. The solvent was removed under reduced pressure and the residual material purified by column chromatography on silica gel (hexanes / ethyl acetate as eluent) to yield enoate 27 (1.82 g, $3.02 \mathrm{mmol}, 80 \%)$ as a pale yellow oil. $\mathrm{R}_{\mathrm{f}}=0.33,25 \%$ ethyl acetate in hexanes; ${ }^{1} \mathrm{H}-\mathrm{NMR}(600 \mathrm{MHz}$, $\left.\mathrm{CDCl}_{3}\right): \delta=7.35-7.28(\mathrm{~m}, 5 \mathrm{H}), 6.63(\mathrm{~d}, \mathrm{~J}=16.2 \mathrm{~Hz}, 1 \mathrm{H}), 6.36(\mathrm{~s}, 1 \mathrm{H}), 5.91-5.85(\mathrm{~m}, 1 \mathrm{H}), 5.83(\mathrm{~d}, \mathrm{~J}=$ $16.2 \mathrm{~Hz}, 1 \mathrm{H}), 5.82-5.76$ (m, 1H), 5.35 (dt, J = 16.2, $1.8 \mathrm{~Hz}, 1 \mathrm{H}), 5.20$ (dt, J = 10.2, $1.8 \mathrm{~Hz}, 1 \mathrm{H}), 4.99$ (ddd, $\mathrm{J}=16.8,3.6,1.8 \mathrm{~Hz}, 1 \mathrm{H}), 4.94-4.92(\mathrm{~m}, 1 \mathrm{H}), 4.86(\mathrm{~s}, 1 \mathrm{H}), 4.53-4.47$ (m, 3H), 4.42 (d, J = 4.2 Hz, 1H), 4.40 (d, J = 6.0 Hz, 1H), 3.81 (s, 3H), 3.61 (s, 3H), 2.57-2.48 (m, 2H), 2.38 (dd, J = 13.2, 2.1 Hz, 1H), 2.24 (dd, J = 13.2, 11.4 Hz, 1H), 2.05-2.01 (m, 2H), 1.61-1.54 (m, 1H), 1.52-1.46 (m, 1H), 1.45-1.35 (m, 2H); ${ }^{13} \mathrm{C}-\mathrm{NMR}\left(100 \mathrm{MHz}, \mathrm{CDCl}_{3}\right): \delta=171.9,166.0,153.2,146.9,145.7,138.9,137.6$, 136.7, 128.4, 127.8 (2 signals), 122.4, 117.1, 114.3, 112.4, 103.9, 71.7, 63.8, 60.0, 54.9, 53.0, 52.9, 51.7, 33.4, 32.9, 26.4, 26.1 ( $1 \mathrm{sp}^{3}$ signal missing); IR (thin film): 2950, 2854, 1733, 1648, 1436, 1318, 1280, 1213, 1173, 1070, 1032, 985, 915, 828, 741, $687 \mathrm{~cm}^{-1}$; HRMS calc'd for $\mathrm{C}_{30} \mathrm{H}_{36} \mathrm{BrNO}_{7}=$ 601.1675, found $=601.1681$.

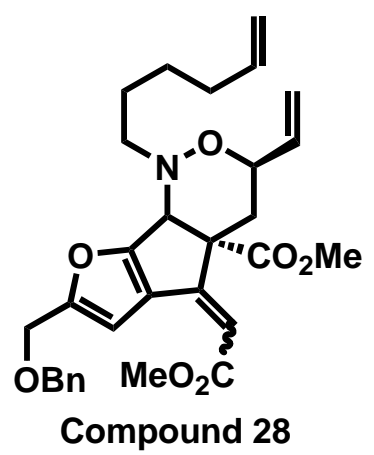
since the double bond would be reduced at a later stage. $\mathrm{R}_{\mathrm{f}}=0.32,25 \%$ ethyl acetate in hexanes; ${ }^{1} \mathrm{H}$ NMR (600 MHz, $\left.\mathrm{CDCl}_{3}\right): \delta=7.37-7.36(\mathrm{~m}, 4 \mathrm{H}), 7.32-7.31(\mathrm{~m}, 1 \mathrm{H}), 6.40(\mathrm{~s}, 1 \mathrm{H}), 5.98-5.92(\mathrm{~m}, 1 \mathrm{H})$, 5.84-5.77 (m, 2H), 5.20 (d, J = 17.4 Hz, 1H), 5.09 (d, J = 10.2 Hz, 1H), 5.01 (d, J = 17.4 Hz, 1H), 4.94 (d, J = 10.2 Hz, 1H), 4.86-4.82 (m, 1H), 4.59 (s, 2H), 4.49 (d, J = 13.2 Hz, 1H), 4.45 (d, J = 13.2 Hz, $1 \mathrm{H}$ ), 4.11 (s, 1H), 3.73 (s, 3H), 3.70 (s, 3H), 3.19-3.14 (m, 1H), 2.90 (dd, J = 7.8, $6.0 \mathrm{~Hz}, 1 \mathrm{H})$, 2.732.69 (m, 1H), 2.09-2.05 (m, 2H), 1.69-1.58 (m, 3H), 1.51-1.42 (m, 2H); ${ }^{13} \mathrm{C}-\mathrm{NMR}\left(100 \mathrm{MHz}, \mathrm{CDCl}_{3}\right)$ : $\delta=172.8,166.5$, 164.0, 159.7, 154.0, 139.0, 138.8, 137.4, 131.5, 128.5, 127.9 (2 signals), 116.0, 114.4, 107.2, 104.5, 76.0, 72.3, 68.7, 64.2, 61.1, 56.2, 52.3, 51.2, 33.5, 32.1, 26.6, 26.3; IR (thin film): 3075, 2950, 2855, 1750, 1713, 1638, 1497, 1435, 1344, 1266, 1230, 1195, 1156, 1072, 994, 921, 855, 806, 771, 740, $699 \mathrm{~cm}^{-1}$; HRMS calc'd for $\mathrm{C}_{30} \mathrm{H}_{35} \mathrm{NO}_{7}=521.2414$, found $=521.2427$.

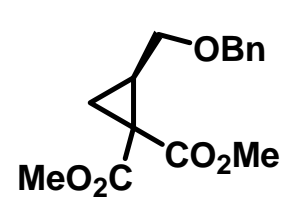

Compound 30

Cyclopropane 30 was prepared using the literature procedure Burgess, K., and Ke, C-Y. Synthesis 1996, 12, 1463, except that dimethyl malonate (15.47 g, 117.09 $\mathrm{mmol}$ ) was used instead of diethyl malonate to yield cyclopropane 11 (25.10 g, $90.23 \mathrm{mmol}, 77 \%)$ as a colorless oil. Also, the compound was purified by chromatography on silica gel (hexanes / ethyl acetate as eluent) instead of distillation. $\mathrm{R}_{\mathrm{f}}=0.46,30 \%$ ethyl acetate in hexanes; ${ }^{1} \mathrm{H}-\mathrm{NMR}\left(600 \mathrm{MHz}, \mathrm{CDCl}_{3}\right)$ : $\delta=7.35-7.26$ (m, 5H), 4.51 (d, J = 12.0 Hz, 1H), 4.43 (d, J = 12.0 Hz, 1H), 3.72 (s, 3H), 3.68 (s, 3H), 3.59 (dd, J = 10.5, 5.4 Hz, 1H), 3.46 (dd, J = 10.5, 7.2 Hz, 1H), 2.29-2.25 (m, 1H), 1.59 (dd, J = 7.8, 
$4.8 \mathrm{~Hz}, 1 \mathrm{H}), 1.46$ (dd, $\mathrm{J}=9.6,4.8 \mathrm{~Hz}, 1 \mathrm{H}) ;{ }^{13} \mathrm{C}-\mathrm{NMR}\left(150 \mathrm{MHz}, \mathrm{CDCl}_{3}\right): \delta=170.2,168.0,137.8$, 128.2, 127.5 (two signals), 72.7, 67.6, 52.5, 52.4, 32.6, 27.2, 18.7; IR (thin film): 3032, 2954, 2923, 2855, 1734, 1456, 1437, 1334, 1291, 1213, 1130, 927, $740 \mathrm{~cm}^{-1}$; HRMS [M+H] calc'd for $\mathrm{C}_{15} \mathrm{H}_{19} \mathrm{O}_{5}=$ 279.1232, found $=279.1236 ;[\alpha]_{D}=-30\left(c=3.9, \mathrm{CHCl}_{3}\right)$

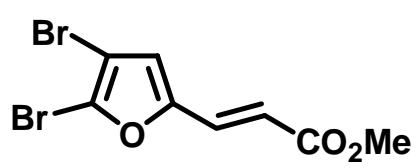

Compound 31b

The procedure is taken from Rathke, M.W.; Nowak, M. J. Org. Chem. 1985, 50, 2624. Lithium bromide (14.50 g, $167.55 \mathrm{mmol})$ was added to THF $(350 \mathrm{~mL})$ and cooled to $0{ }^{\circ} \mathrm{C}$. Trimethylphosphonoacetate $(27.84 \mathrm{~g}$, $152.87 \mathrm{mmol}$ ) was added and the mixture stirred for 5 minutes. Triethylamine (15.47 g, $152.88 \mathrm{mmol}$ ) was added and the mixtures stirred for 10 minutes. 24a (35.28 g, $138.85 \mathrm{mmol}$ ) was added as a solution in THF (50 mL) via cannula, and the reaction stirred for 2 hours at $0{ }^{\circ} \mathrm{C}$, after which TLC indicated complete consumption of the starting material. Water $(100 \mathrm{~mL})$ was added, and the THF removed under reduced pressure. To the remaining aqueous layer was added water $(300 \mathrm{~mL})$ and ethyl acetate $(300 \mathrm{~mL})$ and the layers separated. The aqueous layer was washed three times with ethyl acetate and the combined organic layers were washed twice with $1 \mathrm{M}$ sodium hydroxide, twice with water and once with brine. The organic layer was dried with $\mathrm{MgSO}_{4}$, and concentrated under reduce pressure to yield $\mathbf{3 1 b}$ (41.21 g, $132.88 \mathrm{mmol}, 96 \%$ ) as a brown solid which was of sufficient purity to be used directly in the next step Approximately 5-10\% of an unidentifiable and inseparable isomer was present. If KOtBu was used as the base in this reaction a larger proportion (10-30\%) of this byproduct resulted. $\mathrm{R}_{\mathrm{f}}=0.52$ (20\% ethyl acetate in hexanes) $\quad{ }^{1} \mathrm{H}-\mathrm{NMR}\left(400 \mathrm{MHz}, \mathrm{CDCl}_{3}\right): \delta=7.28(\mathrm{~d}, \mathrm{~J}=15.6 \mathrm{~Hz}, 1 \mathrm{H}), 6.63(\mathrm{~s}, 1 \mathrm{H}), 6.34$ (d, J = $15.6 \mathrm{~Hz}, 1 \mathrm{H}), 3.80$ (s, 3H); ${ }^{13} \mathrm{C}-\mathrm{NMR}\left(150 \mathrm{MHz}, \mathrm{CDCl}_{3}\right): \delta=166.6,152.5,129.1,126.0$, 118.3, 117.4, 104.1, 51.8; IR (thin film): 1718, 1645, 1559, 1431, 1305, 1249, 1188, 1167, 1156, 981, 963, $817 \mathrm{~cm}^{-1}$; HRMS calc'd for $\mathrm{C}_{8} \mathrm{H}_{6} \mathrm{Br}_{2} \mathrm{O}_{3}=307.8684$, found $=307.8690$.

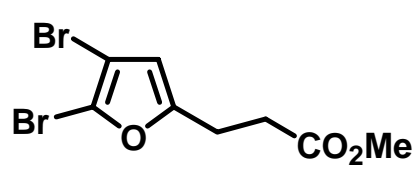

Compound 31c

Sodium acetate (39.68 g, $483.73 \mathrm{mmol})$, p-toluenesulfonhydrazide (63.04 g, $338.51 \mathrm{mmol}$ ) and $\mathbf{3 1 b}$ (30.00 g, $97.64 \mathrm{mmol}$ ) were added to water (500 $\mathrm{mL})$ and THF (500 mL) and the mixture was refluxed for $14 \mathrm{hrs}$, after which TLC indicated a small amount of starting material remained. Sodium acetate (6.00 g, $73.14 \mathrm{mmol})$ and p-toluenesulfonhydrazide (9.00 g, $48.33 \mathrm{mmol}$ ) were added and after refluxing for 4 more hours, TLC indicated complete consumption of the starting material. The reaction was cooled to room temperature and the THF was removed under reduced pressure. The resulting slurry was extracted three times with ether, and the combined organics washed with water then brine and dried with $\mathrm{MgSO}_{4}$. The solvent was removed under reduced pressure and the resulting material was purified by flash column chromatography on silica gel (ethyl acetate / hexanes as eluent) to yield 31c (28.92 g, $92.65 \mathrm{mmol}, 96 \%)$ as a yellow oil. $\mathrm{R}_{\mathrm{f}}=0.49,15 \%$ ethyl acetate in hexanes; ${ }^{1} \mathrm{H}-\mathrm{NMR}$ (400 MHz, $\left.\mathrm{CDCl}_{3}\right): \delta=6.13(\mathrm{~s}, 1 \mathrm{H}), 3.70(\mathrm{~s}, 3 \mathrm{H})$, 2.94 (t, J = 8.0 Hz, 2H), 2.63 (t, J = 8.0 Hz, 2H); ${ }^{13} \mathrm{C}$ NMR (100 MHz, $\left.\mathrm{CDCl}_{3}\right): \delta=172.1,156.4$, 120.6, 111.2, 101.7, 51.7, 31.7, 23.5; IR (thin film): 3121, 2998, 2953, 2847, 1741, 1597, 1524, 1438, 1371, 1336, 1294, 1260, 1200, 1175, 1155, 975, $802 \mathrm{~cm}^{-1}$; HRMS calc'd for $\mathrm{C}_{8} \mathrm{H}_{8} \mathrm{Br}_{2} \mathrm{O}_{3}=309.8840$, found $=309.8845$. 


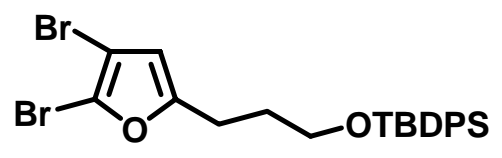

Compound 31d

Dibromoester 31c (27.65 g, $88.55 \mathrm{mmol}$ ) was dissolved in $\mathrm{CH}_{2} \mathrm{Cl}_{2}$ $(800 \mathrm{~mL})$ and cooled to $0{ }^{\circ} \mathrm{C}$. DIBAL $(135 \mathrm{~mL}$ of $1.5 \mathrm{M}$ solution in toluene, $202.50 \mathrm{mmol}$ ) was added dropwise over 30 minutes, and after the addition was complete the reaction was stirred for 30 minutes at 0 ${ }^{\circ} \mathrm{C}$. Water $(20 \mathrm{~mL})$ was added to quench the excess DIBAL (cautiously at first) and the mixture was stirred at $0{ }^{\circ} \mathrm{C}$ for 20 minutes, and then at room temperature for 40 minutes. The reaction was then filtered through celite to remove the gelatinous aluminum precipitate and the filter cake washed with $\mathrm{CH}_{2} \mathrm{Cl}_{2}$. The filtrate was dried with $\mathrm{MgSO}_{4}$, and the solvent removed under reduced pressure to yield the crude alcohol as a yellow oil. Selected data for alcohol : $\mathrm{R}_{\mathrm{f}}=0.10,20 \%$ ethyl acetate in hexanes; ${ }^{1} \mathrm{H}-\mathrm{NMR}\left(600 \mathrm{MHz}, \mathrm{CDCl}_{3}\right): \delta=6.12(\mathrm{~s}, 1 \mathrm{H}), 3.69$ (t, J = 6.3 Hz, 2H), 2.72 (t, J = 7.5 Hz, 2H), 1.90-1.85 (m, 2H); IR (thin film): $v_{\max }=3346$ (broad), 3123, 2944, 2879, 1595, 1523, 1446, 1433, 1298, 1215, 1154, 1058, 995, 977, 949, 933, 795; HRMS calc'd for $\mathrm{C}_{7} \mathrm{H}_{8} \mathrm{Br}_{2} \mathrm{O}_{2}=281.8891$, found $=281.8884$. The alcohol would decompose over a few days at room temperature, and was immediately dissolved in DMF (200 mL). Imidazole $(6.32 \mathrm{~g}, 92.95$ mmol) and N,N-dimethylaminopyridine (a few crystals) were added and the mixture cooled to $0{ }^{\circ} \mathrm{C}$ and stirred for 15 minutes. TBDPSCl (24.32 g, $88.55 \mathrm{mmol}$ ) was added and the reaction allowed to warm to room temperature and stirred for 14 hours. The reaction was poured into water $(1 \mathrm{~L})$ and extracted 3 times with ether $(250 \mathrm{~mL})$. The combined organics were washed with water, dried with $\mathrm{MgSO}_{4}$ and the solvent removed under reduced pressure. The resulting crude oil was purified by flash column chromatography on silica gel (ethyl acetate / hexanes as eluent) to yield 31d (41.76 g, 80.54 mmol, $91 \%$ for two steps) as a pale yellow oil. $\mathrm{R}_{\mathrm{f}}=0.71,10 \%$ ethyl acetate in hexanes; ${ }^{1} \mathrm{H}-\mathrm{NMR}$ (400 $\left.\mathrm{MHz}, \mathrm{CDCl}_{3}\right): \delta=7.71-7.68(\mathrm{~m}, 4 \mathrm{H}), 7.49-7.40(\mathrm{~m}, 6 \mathrm{H}), 6.04(\mathrm{t}, \mathrm{J}=0.8 \mathrm{~Hz}, 1 \mathrm{H}), 3.72$ (t, J = 6.2 Hz, 2H), 2.77 (dt, J = 7.2, $0.8 \mathrm{~Hz}, 2 \mathrm{H}$ ), 1.89 (app p, J = 7.0 Hz, 2H), 1.10 (s, 9H); ${ }^{13} \mathrm{C}-\mathrm{NMR}(100 \mathrm{MHz}$, $\left.\mathrm{CDCl}_{3}\right): \delta=158.3,135.5,133.6,129.7,127.7,120.0,110.8,101.6,62.3$, 30.2, 26.8, 24.7, 19.2; ; IR (thin film): 3071, 3049, 2931, 2894, 2857, 1591, 1472, 1428, 1390, 1361, 1154, 1112, 979, 823, 794, $738 \mathrm{~cm}^{-1}$; HRMS calc'd for $[\mathrm{M}+\mathrm{H}] \mathrm{C}_{23} \mathrm{H}_{27} \mathrm{Br}_{2} \mathrm{O}_{2} \mathrm{Si}=521.0147$, found = 521.0152.

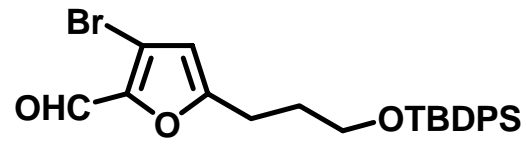

Compound 31

The procedure used is an adaptation from Zaluski, M-C., Robba, M., and Bonhomme, M. Bull. Soc. Chim. Fr. 1970, 1838 for the preparation of a similar compound. n-BuLi (13.3 mL of $1.6 \mathrm{M}$ in hexanes, $21.28 \mathrm{mmol})$ was added to anhydrous ether $(150 \mathrm{~mL})$ and the solution was cooled to $-78{ }^{\circ} \mathrm{C}$. A solution of the dibromofuran 31d (10.00 g, $19.28 \mathrm{mmol})$ in ether $(75 \mathrm{~mL})$ was added dropwise to the $\mathrm{n}$-BuLi, and after addition was complete the mixture was stirred for 30 minutes at $-78{ }^{\circ} \mathrm{C}$. DMF (1.70 g, $\left.26.98 \mathrm{mmol}\right)$ in ether (75 $\mathrm{mL}$ ) was then added dropwise, and after addition was complete the reaction was warmed to room temperature over two hours, and then refluxed for 30 minutes. Water $(5 \mathrm{ml})$ was added to quench the reaction, followed by $5 \% \mathrm{HCl}(300 \mathrm{~mL})$. The layers were separated and the aqueous extracted 3 times with ether. The combined organics were washed with water and dried with $\mathrm{MgSO}_{4}$ and the solvent removed under reduced pressure. Flash column chromatography on silica gel (hexanes / ethyl acetate as eluent) afforded 31 (5.82 g, $12.45 \mathrm{mmol}, 65 \%)$ as a pale yellow oil. $\mathrm{R}_{\mathrm{f}}=0.45,10 \%$ ethyl acetate in hexanes; ${ }^{1} \mathrm{H}-\mathrm{NMR}\left(400 \mathrm{MHz}, \mathrm{CDCl}_{3}\right): \delta=9.60$ (s, 1H), 7.66-7.63 (m, 4H), 7.46-7.36 (m, 6H), 6.22 (s, 1H), 3.69 (t, J = 5.8 Hz, 2H), 2.85 (t, J = 7.6 Hz, 2H), 1.96-1.89 (m, 2H), 1.05 (s, 9H); ${ }^{13} \mathrm{C}-\mathrm{NMR}(100$ $\left.\mathrm{MHz}, \mathrm{CDCl}_{3}\right): \delta=175.2$, 163.2, 146.9, 135.4, 133.4, 129.6, 127.6, 112.5, 62.2, 29.8, 26.7, 24.9, 19.1; 
IR (thin film): 3071, 3049, 2931, 2857, 1677, 1571, 1519, 1472, 1463, 1428, 1384, 1361, 1279, 1112 , 1020, 974, 823, 787, $741 \mathrm{~cm}^{-1}$; HRMS - calc'd for $[\mathrm{M}+\mathrm{H}] \mathrm{C}_{24} \mathrm{H}_{28 \mathrm{Br}} \mathrm{O}_{3} \mathrm{Si}=471.0991$, found = 471.0998 .

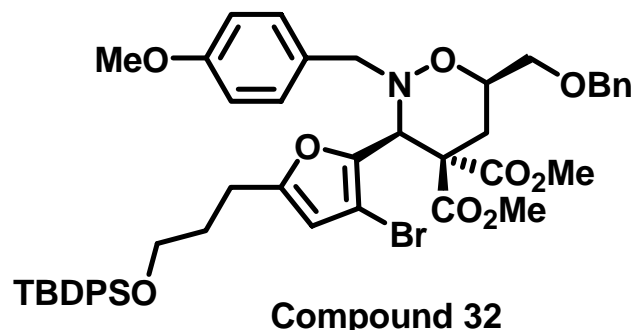

p-Methoxybenzylhydroxylamine 29 (1.73 g, $11.32 \mathrm{mmol})$, aldehyde 31 (5.29 g, $11.32 \mathrm{mmol}), \mathrm{Yb}(\mathrm{OTf})_{3} \cdot \mathrm{xH}_{2} \mathrm{O}(0.88 \mathrm{~g}$, $1.41 \mathrm{mmol})$ and molecular sieves were added to toluene (100 $\mathrm{mL}$ ) and the reaction stirred at room temperature for 3 hours. Cyclopropane 30 ( $2.62 \mathrm{~g}, 9.43 \mathrm{mmol})$ was then added and the reaction heated to $100{ }^{\circ} \mathrm{C}$ for $20 \mathrm{hrs}$, after which NMR analysis of the crude reaction mixture indicated that the cyclopropane had been consumed. The reaction mixture was then cooled to room temperature and filtered through celite. The filter cake was washed with ethyl acetate and the solvent was removed under reduced pressure. The resulting crude residue was purified by flash column chromatography on silca gel (ethyl acetate/hexanes as eluent) to yield cycloadduct $32(7.22 \mathrm{~g}, 8.20 \mathrm{mmol}, 87 \%)$ as a viscous orange oil. $\mathrm{R}_{\mathrm{f}}=0.50,40 \%$ ethyl acetate in hexanes; ${ }^{1} \mathrm{H}-\mathrm{NMR}\left(600 \mathrm{MHz}, \mathrm{CDCl}_{3}\right): \delta=7.66-$ 7.65 (m, 4H), 7.43-7.36 (m, 6H), 7.26-7.24 (m, 2H), 7.21-7.17 (m, 5H), 6.79 (d, J = 8.4 Hz, 2H), 6.01 (s, 1H), 4.98 (s, 1H), 4.38 (s, 2H), 4.21-4.19 (m, 1H), 3.80 (s, 3H), 3.76 (s, 3H), 3.71 (d, J = $13.8 \mathrm{~Hz}$, $1 \mathrm{H})$, 3.66-3.60 (m, 3H), 3.53 (d, J = 5.4 Hz, 2H), $3.46(\mathrm{~s}, 3 \mathrm{H}), 2.72(\mathrm{t}, \mathrm{J}=7.8 \mathrm{~Hz}, 2 \mathrm{H}), 2.47$ (dd, J = 13.8, $12.0 \mathrm{~Hz}, 1 \mathrm{H}), 2.35$ (dd, J = 13.8, $2.4 \mathrm{~Hz}, 1 \mathrm{H}), 1.90-1.79$ (m, 2H), 1.06 (s, 9H); ${ }^{13} \mathrm{C}-\mathrm{NMR}(150$ $\left.\mathrm{MHz}, \mathrm{CDCl}_{3}\right): \delta=169.2$, 168.1, 158.6, 157.0, 144.8, 138.2, 135.4, 133.6, 129.8, 129.5, 128.9, 128.0, 127.6, 127.4, 127.2, 113.2, 108.8, 103.0, 76.1, 72.9, 71.8, 62.4, 58.4, 57.7, 57.5, 55.0, 53.0, 52.5, 30.1, 28.1, 26.8, 24.5, 19.1; IR (thin film): 3000, 2953, 2858, 1743, 1613, 1589, 1514, 1430, 1362, 1303, 1250, 1179, 1112, 1038, 1008, 965, 824, 739, $703 \mathrm{~cm}^{-1}$; HRMS calc'd for $\mathrm{C}_{47} \mathrm{H}_{54} \mathrm{BrNO}_{9} \mathrm{Si}=883.2751$, found $=883.2730 ;[\alpha]_{\mathrm{D}}=+35.9\left(c=11.52, \mathrm{CHCl}_{3}\right)$

The enantiomeric excess of $\mathbf{3 2}$ could not be determined due to the -TBDPS making it difficult to separate the enantiomers of a racemic sample of 32 using chiral HPLC. As a result, HPLC Compound 1 was prepared from 32.

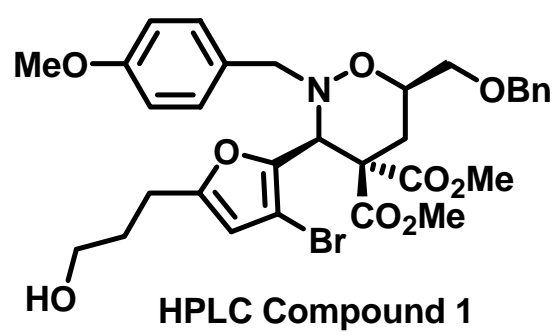

of the solvent under reduced pressure produced an oil that was purified by column chromatography on silica gel (ethyl acetate / hexanes as eluent) to yield HPLC Compound 1 (108 mg, 0.167 mmol, 92 $\%)$ as a pale yellow oil. $\mathrm{R}_{\mathrm{f}}=0.30,60 \%$ ethyl acetate in hexanes; ${ }^{1} \mathrm{H}-\mathrm{NMR}\left(600 \mathrm{MHz}, \mathrm{CDCl}_{3}\right): \delta=$ 7.31 (t, 7.5 Hz, 2H), 7.27-7.21 (m, 5H), 6.81 (d, J = 6.6 Hz, 2H), 6.08 (s, 1H), 4.99 (s, 1H), 4.48-4.42 (m, 2H), 4.19-4.17 (m, 1H), 3.81 (s, 3H), 3.76 (s, 3H), 3.73 (d, J = 13.8 Hz, 1H), 3.64 (d, J = 13.8 Hz, 1H), 3.60-3.55 (m, 4 H), 3.53 (s, 3H), 2.73-2.65 (m, 2H), 2.56 (dd, J = 13.8, 12.0 Hz, 1H), 2.35 (dd, J 
$=13.8,1.8 \mathrm{~Hz}, 1 \mathrm{H}), 1.88-1.79(\mathrm{~m}, 2 \mathrm{H}), 1.63(\mathrm{br} \mathrm{s}, 1 \mathrm{H}) ;{ }^{13} \mathrm{C}-\mathrm{NMR}\left(100 \mathrm{MHz}, \mathrm{CDCl}_{3}\right): \delta=169.3$, 168.4, 158.6, 157.1, 144.8, 138.2, 130.0, 128.8, 128.2, 127.6, 127.4, 113.3, 108.9, 103.3, 76.1, 73.1, 71.6, 61.4, 58.5, 57.8, 57.4, 55.1, 53.2, 52.7, 30.6, 28.0, 24.6; IR (thin film): 3448, 3032, 3002, 2953, $1741,1616,1514,1465,1457,1437,1302,1250,1176,1102,1036,1006,969,918,825,739, \mathrm{~cm}^{-1}$; HRMS calc'd for $\mathrm{C}_{31} \mathrm{H}_{36} \mathrm{BrNO}_{9}=645.1574$, found $=645.1578 ;[\alpha]_{\mathrm{D}}=+46.5\left(c=1.80, \mathrm{CHCl}_{3}\right)$.

The enantiomeric excess was determined to be $>95 \%$ by chiral HPLC (Chiralcel OD-H, $250 \times 4.6$ $\mathrm{mm}^{2}$, Diacel Chemical Industries; 93:7 Hexanes / $i-\mathrm{PrOH}$ at $1.5 \mathrm{~mL} / \mathrm{min} ; 220 \mathrm{~nm}$; The retention time for the enantiomers of the racemic sample were $\mathrm{r}_{1}(+)=13.5 \mathrm{~min}, \mathrm{r}_{\mathrm{l}}(-)=15.7 \mathrm{~min}$.
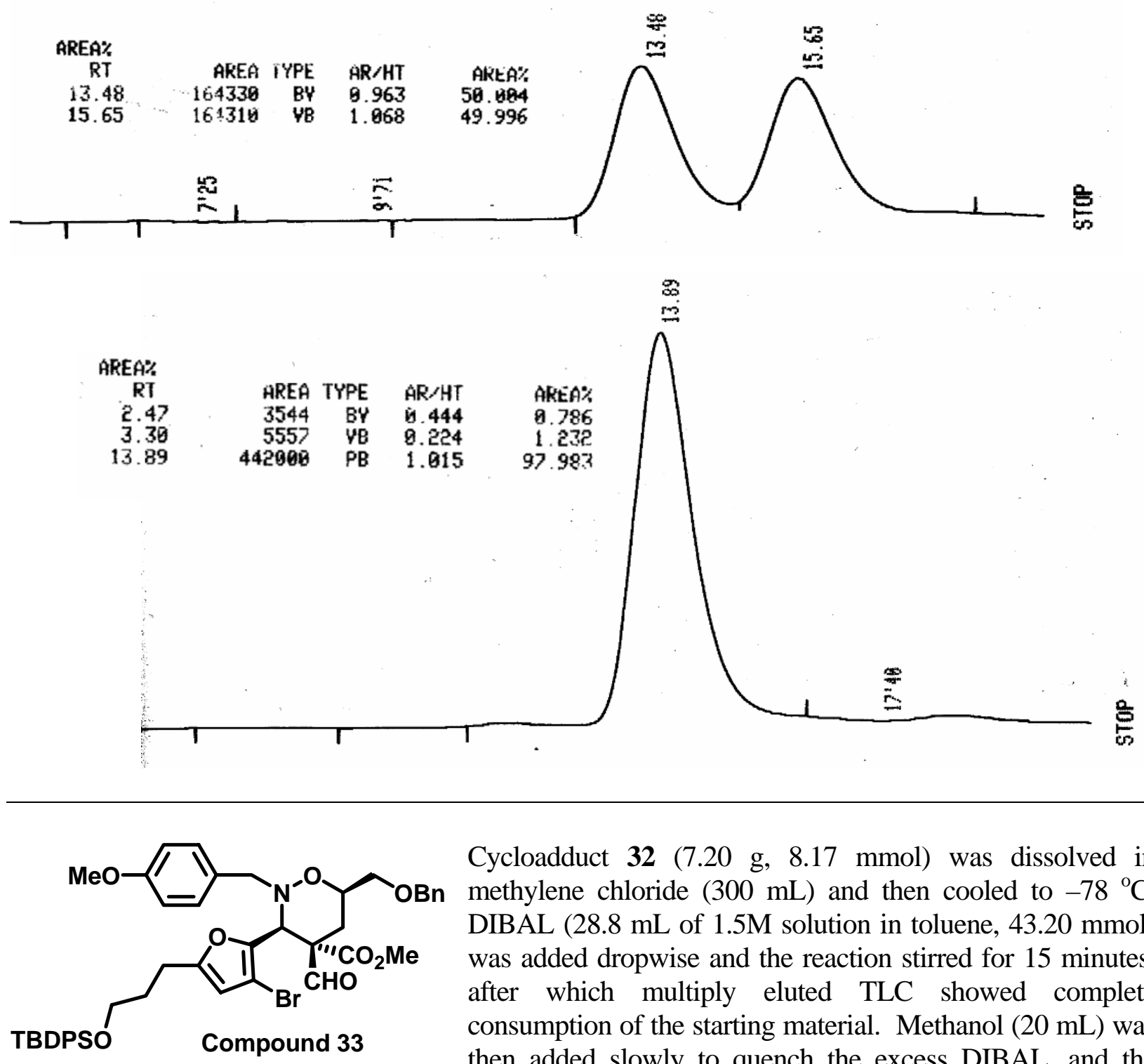

Cycloadduct 32 (7.20 g, $8.17 \mathrm{mmol})$ was dissolved in methylene chloride $(300 \mathrm{~mL})$ and then cooled to $-78{ }^{\circ} \mathrm{C}$. DIBAL (28.8 mL of $1.5 \mathrm{M}$ solution in toluene, $43.20 \mathrm{mmol}$ ) was added dropwise and the reaction stirred for 15 minutes, after which multiply eluted TLC showed complete consumption of the starting material. Methanol $(20 \mathrm{~mL})$ was then added slowly to quench the excess DIBAL, and the mixture stirred at $-78{ }^{\circ} \mathrm{C}$ for 20 minutes, after which it was removed from the dry ice bath and allowed to warm to room temperature. The reaction was then poured into $5 \% \mathrm{HCl}(300 \mathrm{~mL})$ and the layers separated. The aqueous layer was extracted 3 times with methylene chloride, and the combined organics washed with $5 \% \mathrm{HCl}$. The organic layer was dried with $\mathrm{MgSO}_{4}$, and the solvent removed 
under reduced pressure. The residual material was purified by flash column chromatography on silica gel (hexanes / ethyl acetate as eluent) to yield aldehyde 33 (6.08 g, $7.15 \mathrm{mmol}, 87 \%)$ as viscous yellow oil. $\mathrm{R}_{\mathrm{f}}=0.50,40 \%$ ethyl acetate in hexanes; ${ }^{1} \mathrm{H}-\mathrm{NMR}\left(400 \mathrm{MHz}, \mathrm{CDCl}_{3}\right): \delta=9.17(\mathrm{~s}, 1 \mathrm{H}), 7.66-7.64$ (m, 4H), 7.44-7.36 (m, 6H), 7.28-7.24 (m, 2H), 7.22-7.17 (m, 5H), 6.88 (d, J = 8.4 Hz, 2H), 6.01 (s, 1H), 5.05 (s, 1H), 4.40 (s, 2H), 4.40-4.34 (m, 1H), 3.83 (s, 3H), 3.76 (s, 3H), 3.75 (d, J = 13.6 Hz, 1H), 3.65-3.60 (m 3H), 3.55-3.54 (m, 2H), 2.70 (t, J = 7.4 Hz, 2H), 2.26 (dd, J = 13.8, 11.4 Hz, 1H), 2.18 (dd, J = 13.8, $2.8 \mathrm{~Hz}, 1 \mathrm{H}), 1.86-1.78$ (m, 2H), 1.06 (s, 9H); ${ }^{13} \mathrm{C}-\mathrm{NMR}\left(100 \mathrm{MHz}, \mathrm{CDCl}_{3}\right): \delta=194.8$, 168.7, 158.6, 158.0, 143.7, 138.1, 135.4, 133.5, 129.8, 129.5, 128.5, 128.1, 127.6, 127.4, 127.3, 113.2, 108.8, 103.8, 75.9, 72.9, 71.7, 62.8, 62.4, 58.1, 56.7, 55.0, 53.1, 30.1, 26.7, 24.9, 24.5, 19.1; IR (thin film): 3071, 3048, 3032, 3012, 3000, 2954, 2932, 2906, 2897, 2858, 1751, 1722, 1613, 1514, 1429, 1389, 1362, 1303, 1248, 1174, 1111, 1107, 1035, 1009, 999, 970, 823, 806, 740, $701 \mathrm{~cm}^{-1}$; HRMS calc'd for $\mathrm{C}_{46} \mathrm{H}_{52} \mathrm{BrNO}_{8} \mathrm{Si}=853.2646$, found $=853.2619 ; \quad[\alpha]_{\mathrm{D}}=+34.4\left(c=1.67 \mathrm{CHCl}_{3}\right)$

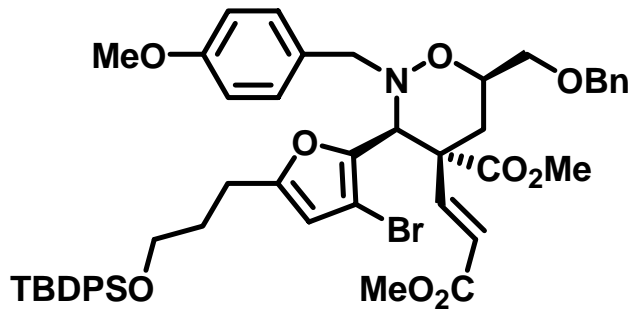

Compound 34

Trimethyl phosphonoacetate (2.96 g, $16.28 \mathrm{mmol}$ ) was dissolved in THF (400 mL) and cooled in an ice bath. $\mathrm{KOtBu}$ (1.83 g, $16.28 \mathrm{mmol}$ ) was added in small portions and after addition was complete, the slurry was stirred for 10 minutes. Aldehyde 33 (11.54 g, $13.57 \mathrm{mmol}$ ) in THF (100 $\mathrm{mL}$ ) was then added slowly via cannula, and TLC indicated complete consumption of the starting material after 11 hours. Water $(50 \mathrm{~mL})$ was added, and the THF removed under reduced pressure. To the resulting residue was added water $(500 \mathrm{~mL}), 5 \% \mathrm{HCl}(20 \mathrm{~mL})$ and ethyl acetate $(200 \mathrm{~mL})$. The layers were separated, and the aqueous washed 3 times with ethyl acetate. The combined organics were washed once with $1 \mathrm{M} \mathrm{NaOH}$ and twice with water, followed by brine. The combined organics were dried with $\mathrm{MgSO}_{4}$, the solvent removed under reduced pressure, and the residual material purified by column chromatography on silica gel (hexanes / ethyl acetate as eluent) to yield enoate 34 (11.40 g, $12.54 \mathrm{mmol}, 93 \%$ ) as a viscous yellow oil. In most cases this compound was of high purity and did not need to be purified by column. $\mathrm{R}_{\mathrm{f}}=0.50,40 \%$ ethyl acetate in hexanes; ${ }^{1} \mathrm{H}$ NMR (400 MHz, $\left.\mathrm{CDCl}_{3}\right): \delta=7.66-7.64(\mathrm{~m}, 4 \mathrm{H}), 7.45-7.36(\mathrm{~m}, 6 \mathrm{H}), 7.28-7.24(\mathrm{~m}, 2 \mathrm{H}), 7.22-7.15(\mathrm{~m}$, 5H), 6.79 (d, J = 8.8 Hz, 2H), 6.58 (d, J = 16.0 Hz, 1H), 5.99 (s, 1H), 5.75 (d, J = 16.0 Hz, 1H), 4.81 (s, $1 \mathrm{H}), 4.40$ (s, 2H), 4.40-4.32 (m, 1H), 3.77 (s, 3H), 3.76 (s, 3H), 3.71 (d, J = 13.6 Hz, 1H), 3.64-3.60 (m, 3H), 3.58 (s, 3H), 3.53 (d, J = 4.8 Hz, 2H), 2.69 (t, J = 7.4 Hz, 2H), 2.23 (dd, J = 13.8, 2.4 Hz, 1H), 2.14 (dd, J = 13.8, $13.4 \mathrm{~Hz}, 1 \mathrm{H}), 1.89-1.84(\mathrm{~m}, 2 \mathrm{H}), 1.05$ (s, 9H); ${ }^{13} \mathrm{C}-\mathrm{NMR}\left(100 \mathrm{MHz}, \mathrm{CDCl}_{3}\right): \delta=$ 171.7, 165.7, 158.5, 157.1, 145.8, 144.6, 138.1, 135.3, 133.5, 129.7, 129.5, 128.8, 128.0, 127.5, 127.4, 127.3, 121.9, 113.1, 108.7, 103.7, 76.1, 72.8, 71.6, 62.2, 59.2, 58.3, 54.9, 52.7 (2 signals), 51.4, 30.2, 29.1, 26.7, 24.4, 19.0; IR (thin film): 3071, 3047, 3030, 3011, 2999, 2952, 2933, 2898, 2858, 1734, 1653, 1613, 1589, 1514, 1429, 1317, 1247, 1173, 1111, 1106, 1037, 976, 912, 824, 739, $702 \mathrm{~cm}^{-1}$; HRMS calc'd for $\mathrm{C}_{49} \mathrm{H}_{56} \mathrm{BrNO}{ }_{9} \mathrm{Si}=909.2908$, found $=909.2873 ;[\alpha]_{\mathrm{D}}=+45.2\left(c=3.07, \mathrm{CHCl}_{3}\right)$ 


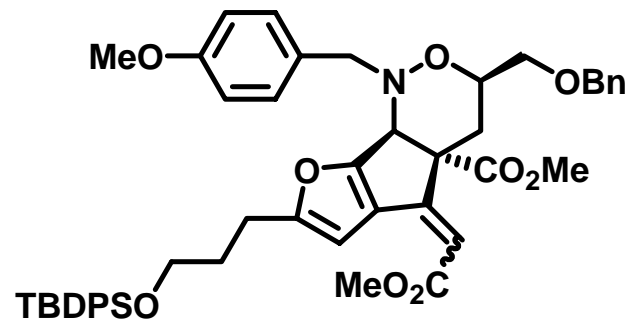

Compound 35

Enoate 34 (11.44 g, $12.62 \mathrm{mmol}$ ) was dissolved in DMF (300 $\mathrm{mL}$ ) and $\mathrm{Ag}_{2} \mathrm{SO}_{4}$ (3.92 g, $12.62 \mathrm{mmol}$ ), $\mathrm{NEt}_{3}$ (5.10 g, 50.46 $\mathrm{mmol})$, and $\mathrm{Pd}\left(\mathrm{PPh}_{3}\right)_{4}(1.46 \mathrm{~g}, 1.26 \mathrm{mmol})$ added. The mixture was refluxed for 1 hour, after which TLC indicated complete consumption of the starting material. The reaction mixture was poured into water (1200 mL) and 5\% $\mathrm{HCl}(200$ $\mathrm{mL}$ ) and extracted 4 times with ether. The combined organics were washed with water, and dried with $\mathrm{MgSO}_{4}$. The solvent was removed under reduced pressure and the residue purified by column chromatography on silica (hexanes/ethyl acetate as eluent) to produce 35 (8.56 g, 10.37 $\mathrm{mmol}, 82 \%)$ as an orange foam. Only one double bond isomer was produced but the configuration was not determined since the double bond would be reduced at a later stage. $\mathrm{R}_{\mathrm{f}}=0.39$, $40 \%$ ethyl acetate in hexanes; ${ }^{1} \mathrm{H}-\mathrm{NMR}\left(600 \mathrm{MHz}, \mathrm{CDCl}_{3}\right)$ : $\delta=7.67-7.66(\mathrm{~m}, 4 \mathrm{H}), 7.44-7.42(\mathrm{~m}, 2 \mathrm{H}), 7.40-7.37$ (m, 4H), 7.30-7.27 (m, 4H), 7.23-7.21 (m, 1H), 7.16-7.14 (m, 2H), 6.80-6.78 (m, 2H), 6.02 (s, 1H), 5.78 (s, 1H), 4.64-4.59 (m, 1H), 4.26 (d, J = 12.6 Hz, 1H), 4.20 (s, 1H), 4.13 (d, J = 12.6 Hz, 1H), 3.91 (d, J = 12.0 Hz, 1H), 3.76-3.74 (m, 6H), 3.70 (s, 3H), 3.68 (s, 3H), 3.18-3.11 (m, 2H), 2.82-2.77 (m, 3H), 1.92 (p, J = 7.2 Hz, 2H), 1.44 (dd, J = 13.2, $10.2 \mathrm{~Hz}, 1 \mathrm{H}), 1.06$ (s, 9H); ${ }^{13} \mathrm{C}-\mathrm{NMR}(150 \mathrm{MHz}$, $\left.\mathrm{CDCl}_{3}\right): \delta=172.5,166.2$, 164.4, 162.1, 158.6, 154.3, 138.4, 135.2, 133.4, 130.7, 129.4, 128.9, 127.8, 127.5, 127.1, 126.9, 113.1, 106.3, 100.3, 74.3, 72.5, 71.9, 68.2, 62.3, 60.7, 59.5, 54.7, 51.8, 50.8, 30.1, 28.7, 26.6, 24.9, 18.9; IR (thin film): 3070, 3031, 299, 2951, 2857, 1751, 1717, 1635, 1513, 1457, 1430, 1341, 1250, 1195, 1155, 1107, 1030, 982, 925, 855, 822, 804, 738, $702 \mathrm{~cm}^{-1}$; HRMS calc'd for $\mathrm{C}_{49} \mathrm{H}_{55} \mathrm{NO}_{9} \mathrm{Si}=829.3646$, found $=829.3662 ;[\alpha]_{\mathrm{D}}=-65.5\left(c=2.50, \mathrm{CHCl}_{3}\right)$.

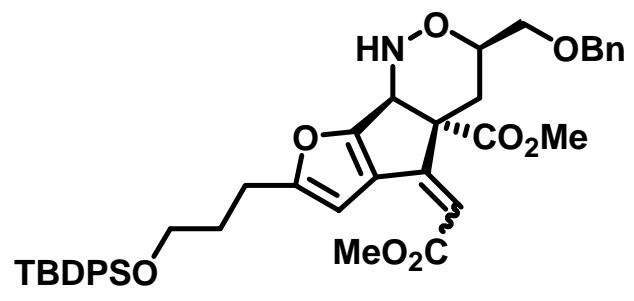

Compound 36

Heck product 35 (25.20 g, $30.51 \mathrm{mmol}$ ) was dissolved in $\mathrm{CH}_{2} \mathrm{Cl}_{2}(450 \mathrm{~mL})$ and water $(45 \mathrm{~mL})$ was added. The reaction was stirred vigorously and cooled to $0{ }^{\circ} \mathrm{C}$, and $2,3-$ dichloro-5,6-dicyano-1,4-benzoquinone (DDQ) (7.43 g, 32.73 mmol) was added. The reaction was kept at $0{ }^{\circ} \mathrm{C}$ for 20 minutes, and then allowed to stir at room temperature for 5 hours. TLC analysis of the reaction mixture showed that starting material still remained, but the reaction was stopped due to the formation of imine by-product. Ethyl acetate was added (1.2 litres) and the reaction mixture poured into $500 \mathrm{~mL}$ of saturated $\mathrm{NaHCO}_{3}$ solution. The layers were separated, and the aqueous layer was extracted 3 times with ethyl acetate, and the combined organic layers were washed with saturated $\mathrm{NaHCO}_{3}$ and brine and dried with $\mathrm{MgSO}_{4}$. The solvent was removed under reduced pressure to yield a residue that was purified by column chromatography on silica gel (hexanes / ethyl acetate as eluent) to yield the product 36 (9.66 g, $13.71 \mathrm{mmol}, 45 \%$ ) as an off white foam. $8.32 \mathrm{~g}$ of a 3:1 mix of starting material to imine by-product was also recovered and was resubjected to the reaction above using $4.01 \mathrm{~g}$ (17.68 mmol) of DDQ, $135 \mathrm{~mL}$ of $\mathrm{CH}_{2} \mathrm{Cl}_{2}$ and $15 \mathrm{~mL}$ of water. After 2 hours the reaction was worked up and purified as above to yield an additional $2.88 \mathrm{~g}$ (4.09 mmol) of product, bringing the overall yield after one recycle to $12.54 \mathrm{~g}, 17.79 \mathrm{mmol}, 58 \%$. $\mathrm{R}_{\mathrm{f}}=0.30,40 \%$ ethyl acetate in hexanes; ${ }^{1} \mathrm{H}-\mathrm{NMR}\left(600 \mathrm{MHz}, \mathrm{CDCl}_{3}\right): \delta=7.66-7.65(\mathrm{~m}, 4 \mathrm{H}), 7.44-7.41(\mathrm{~m}, 2 \mathrm{H})$, 7.39-7.37 (m, 4H), 7.33-7.24 (m, 5H), 5.99 (s, 1H), 5.79 (s, 1H), 5.40 (d, J = 4.5 Hz, 1H), 4.56 (d, J = $12.3 \mathrm{~Hz}, 1 \mathrm{H})$, 4.50 (d, J = 12.3 Hz, 1H), 4.47 (d, J = 4.5 Hz, 1H), 4.34-4.31 (m, 1H), 3.72-3.70 (m, 5H), 3.69 (s, 3H), 3.48 (dd, $\mathrm{J}=11.1,3.0 \mathrm{~Hz}, 1 \mathrm{H}$ ), 3.41 (dd, $\mathrm{J}=11.1,6.0 \mathrm{~Hz}, 1 \mathrm{H}$ ), 2.84 (dd, $\mathrm{J}=14.4,3.0 \mathrm{~Hz}, 1 \mathrm{H}$ ), 2.79 (t, 
$\mathrm{J}=7.5 \mathrm{~Hz}, 2 \mathrm{H}), 1.91$ (p, J = 7.5 Hz, 2H), 1.63 (dd, J = 14.4, $11.4 \mathrm{~Hz}, 1 \mathrm{H}), 1.06$ (s, 9H); ${ }^{13} \mathrm{C}-\mathrm{NMR}$ $\left(100 \mathrm{MHz}, \mathrm{CDCl}_{3}\right): \delta=172.7,166.8,164.8,161.8,154.5,137.9,135.5,133.7,130.2,129.6,128.3$ 127.7, 127.6 (2 signals), 106.5, 100.5, 76.0, 73.4, 72.1, 62.6, 61.1, 55.9, 52.3, 51.2, 30.3, 30.0, 26.8, 25.2, 19.2; IR (thin film): 3256, 3089, 3071, 3051, 3030, 2999, 2951, 2931, 2896, 2858, 1737, 1710, 1638, 1429, 1343, 1231, 1197, 1168, 1155, 1111, 1029, 824, 738, $702 \mathrm{~cm}^{-1}$; HRMS calc'd for $\mathrm{C}_{41} \mathrm{H}_{47} \mathrm{NO}_{8} \mathrm{Si}=709.3071$, found $=709.3076 ;[\alpha]_{\mathrm{D}}=-38.6\left(c=2.33, \mathrm{CHCl}_{3}\right)$.

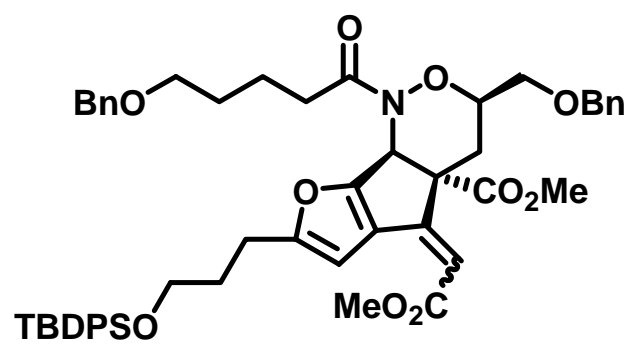

Compound 37

Oxazine 36 (12.54 g, $17.79 \mathrm{mmol}$ ) and triethylamine (5.40 g, $53.36 \mathrm{mmol})$ were dissolved in $\mathrm{CH}_{2} \mathrm{Cl}_{2}(160 \mathrm{~mL})$ and cooled to $0{ }^{\circ} \mathrm{C}$. A solution of acid chloride (5.70 g, $24.92 \mathrm{mmol}$, see preparation below) in $\mathrm{CH}_{2} \mathrm{Cl}_{2}(80 \mathrm{~mL})$ was added dropwise and the reaction stirred at room temperature for 18 hours. The reaction was poured into water $(200 \mathrm{~mL})$ and the layers separated. The aqueous layer was extracted three times with $\mathrm{CH}_{2} \mathrm{Cl}_{2}$ and the combined organics were washed with $5 \%$ $\mathrm{HCl}, 1 \mathrm{M} \mathrm{NaOH}$, and brine, and then dried with $\mathrm{MgSO}_{4}$. The solvent was removed under reduced pressure to yield a residue that was purified by column chromatography on silica gel (hexanes / ethyl acetate as eluent) to yield the product 37 (14.27 g, 15.91 mmol, $89 \%)$ as a viscous yellow oil. A small amount of starting material 36 (0.43 g, $0.61 \mathrm{mmol})$ was also recovered. $\mathrm{R}_{\mathrm{f}}=0.40,40 \%$ ethyl acetate in hexanes; ${ }^{1} \mathrm{H}-\mathrm{NMR}\left(600 \mathrm{MHz}, \mathrm{CDCl}_{3}\right): \delta=7.66-7.65$ (m, 4H), 7.44-7.41 (m, 2H), 7.38 (t, J = 7.4 Hz, 4H), 7.33-7.25 (m, 10H), 6.08 (s, 1H), 5.98 (s, 1H), 5.79 (s, 1H), 4.52 (s, 2H), 4.48 (s, 2H), 4.44-4.40 (m, 1H), 3.71-3.69 (m, 8H), 3.51 (dd, J = 11.4, 2.4 Hz, 2H), 3.48 (t, J = 6.3 Hz, 2H), 3.41 (dd, J = 11.4, 7.2 Hz, 1H), 2.83 (dd, J = 13.8, 2.4 Hz, 1H), 2.77 (t, J = 7.8 Hz, 2H), 2.73-2.67 (m, 1H), 2.61-2.56 (m, 1H), 1.91-1.86 (m, 2H), 1.80-1.75 (m, 2H), 1.67 (p, J = 7.8 Hz, 2H), 1.61 (dd, J = 13.8, $11.7 \mathrm{~Hz}, 1 \mathrm{H}), 1.06$ (s, 9H); ${ }^{13} \mathrm{C}-\mathrm{NMR}\left(100 \mathrm{MHz}, \mathrm{CDCl}_{3}\right): \delta=$ 173.7, 171.3, 166.5, 164.7, 160.3, 153.1, 138.4, 137.5, 135.3, 133.3 (2 signals), 129.9, 129.4, 128.1, 128.0, 127.4, 127.3, 127.1, 109.4, 106.6, 100.4, 79.1, 73.0, 72.5, 70.8, 69.7, 62.3, 55.8, 53.0, 52.2, 51.0, 31.6, 31.0, 30.0, 29.0, 26.6, 24.9, 20.9, 18.9; IR (thin film): 3069, 3031, 2931, 2857, 1741, 1707, 1676, 1636, 1560, 1473, 1457, 1430, 1395, 1344, 1201, 1152, 1106, 1017, 965, 923, 852, 823, 739, $702 \mathrm{~cm}^{-1}$; HRMS calc'd for $\mathrm{C}_{53} \mathrm{H}_{61} \mathrm{NO}_{10} \mathrm{Si}=899.4065$, found $=899.4045 ;[\alpha]_{\mathrm{D}}=-77.7(c=3.24$, $\left.\mathrm{CHCl}_{3}\right)$.

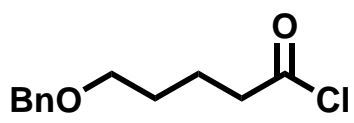

5-benzyloxy-n-pentanoic acid was prepared by modifying the procedure of Borjesson, L.; Corsegh, I.; and Welch, C.A. J. Org. Chem. 1995, 60, 2989. For a reference that contains full data for the acid, as well as scans of the proton and carbon spectra, see Jacobi, P.A.; Li, Y.; Org. Lett. 2003, 5, 701. A solution of 1,5-pentanediol (98.91 g, $949.68 \mathrm{mmol})$ in THF (200 mL) was added via an addition funnel over 30 minutes to a slurry of $\mathrm{NaH}$ (3.91 g, $6.51 \mathrm{~g}$ of $60 \%$ suspension in mineral oil, $162.84 \mathrm{mmol})$ in THF $(400 \mathrm{~mL})$ at $0{ }^{\circ} \mathrm{C}$. After stirring for 30 minutes at this temperature, a solution of benzyl bromide (23.20 g, $135.64 \mathrm{mmol})$ in THF (200 mL) was added over 30 minutes via an addition funnel. The reaction was warmed to room temperature, and stirred for 20 hours. Water $(20 \mathrm{~mL})$ was then added, and the THF removed under reduced pressure to yield an oil that was partitioned between water (1 L) and ethyl acetate (250 $\mathrm{mL}$ ). The layers were separated, and the aqueous layer washed 3 times with EtOAc. The combined organic layers were washed 6 times with water (150 mL each wash), and then dried with $\mathrm{MgSO}_{4}$. Removal of the solvent under reduced pressure produced a colorless oil (24.60 g, $126.62 \mathrm{mmol}, 98 \%)$ 
that was of high purity and could be used without further purification. 5-benzyloxy-1-pentanol (14.32 g, $73.71 \mathrm{mmol})$ was dissolved in acetone $(400 \mathrm{~mL})$ and the solution cooled to $0{ }^{\circ} \mathrm{C}$. Jones Reagent (184.25 mmol, $275 \mathrm{~mL}$ of an $\sim 0.67 \mathrm{M}$ solution) was added dropwise over 20 minutes, and the reaction was kept at $0{ }^{\circ} \mathrm{C}$ for one hour. Isopropanol $(20 \mathrm{~mL})$ was then added, and stirring at $0{ }^{\circ} \mathrm{C}$ continued for 30 minutes. Solid sodium bicarbonate was added cautiously until the solution was neutral, and the chromium precipitate was removed by filtration through celite with the filter cake being washed with acetone and ether. The acetone and ether were removed under reduced pressure, and the solution was made basic $(\mathrm{pH}>12)$ with solid $\mathrm{NaOH}$. The aqueous layer was extracted 3 times with ether, and then made acidic $(\mathrm{pH}<1)$ with concentrated $\mathrm{HCl}$. The aqueous layer was extracted 3 times with ether, and the combined organics dried with $\mathrm{MgSO}_{4}$ and the solvent removed under reduced pressure to produce the acid as a dark green oil, which was of high purity by NMR. Purification by a small silica column (hexanes / ethyl acetate as eluent, $R_{f}=0.50,50 \%$ ethyl acetate/hexanes) yielded the desired acid (8.81 g, $41.90 \mathrm{mmol}, 57 \%)$ as a white, low melting solid. Spectroscopic data was consistent with the literature references The desired acid chloride was prepared according to the following procedure; 5benzyloxy-n-pentanoic acid (5.52 g, $26.22 \mathrm{mmol}$ ) was dissolved in $80 \mathrm{~mL}$ of toluene, and 8 drops of DMF was added. Oxalyl chloride (4.66 g, $36.74 \mathrm{mmol})$ was then added dropwise, and the reaction stirred at room temperature for 30 minutes. The reaction was then heated to $60{ }^{\circ} \mathrm{C}$ for 1.5 hours. After cooling to room temperature, the toluene was removed under reduced pressure to produce the acid chloride as an orange oil. This acid chloride was dissolved in $\mathrm{CH}_{2} \mathrm{Cl}_{2}(80 \mathrm{~mL})$ and used directly in the reaction above.

Compounds 39 were prepared in three steps from 37 without full characterization of the intermediates. The aminoalcohols resulting from $\mathrm{N}-\mathrm{O}$ bond cleavage were susceptible to lactonization, and as a result were immediately mesylated after rapid column chromatography. The mesylates were also unstable, with decomposition products visible 30 minutes after rapid chromatography. As a result $\mathbf{3 7}$ was quickly converted into the appropriate pyrrolidines $\mathbf{3 9}$ over three successive steps.

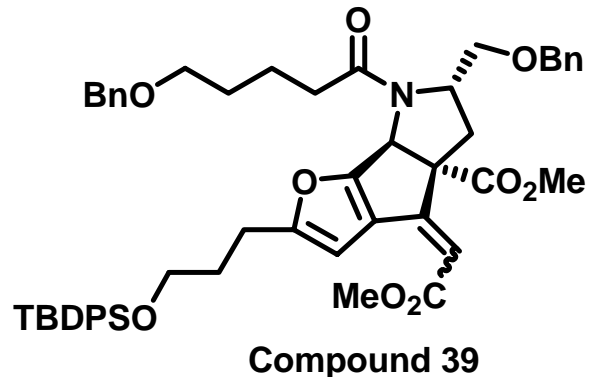

Compound 37 (1.97 g, $2.20 \mathrm{mmol}$ ) was dissolved in THF (30 $\mathrm{mL}$ ) and cooled to $0{ }^{\circ} \mathrm{C}$. A $0.1 \mathrm{M}$ solution of $\mathrm{SmI}_{2}$ (prepared by refluxing $3.43 \mathrm{~g}$ (13.50 mmol) of iodine and $2.23 \mathrm{~g}(14.81 \mathrm{mmol})$ of Sm metal ( 40 mesh) in THF (135 mL) for three hours (the deep blue color should be present after $\sim 20 \mathrm{~min})$ ) cooled to $0{ }^{\circ} \mathrm{C}$ was added rapidly via cannula, and after 30 minutes the deep blue color had faded. Saturated $\mathrm{NaHCO}_{3}(30 \mathrm{~mL})$ was added, and the mixture stirred for 5 minutes. The resulting precipitate was removed by filtration through celite, the filter cake was washed with EtOAc, and the THF and EtOAc was removed under reduce pressure, with a rotory evaporator bath at less than $30{ }^{\circ} \mathrm{C}$. Water was added $(100 \mathrm{~mL})$ and the aqueous layer extracted 3 times with EtOAc. The combined organics were dried with $\mathrm{MgSO}_{4}$, and concentrated under reduced pressure with a bath temp of less than $30{ }^{\circ} \mathrm{C}$. TLC analysis of the worked up reaction mixture indicated that lactonization was starting to occur, so the resulting orange oil was subjected to rapid flash column chromatography on silica (ethyl acetate / hexanes as eluent) to yield the non-isomerized amidoalcohol $\left(1.36 \mathrm{~g}, 1.51 \mathrm{mmol}, \mathrm{R}_{\mathrm{f}}=0.18,50 \%\right.$ ethyl acetate in hexanes) and an amidoalcohol in which the double bond had isomerised (0.273 $\mathrm{g}, 0.306$ mmol, $R_{\mathrm{f}}=0.36,50 \%$ ethyl acetate in hexanes) as yellow oils. Each amidoalcohol was independently 
subjected to the following procedure. The amidoalcohol (non-isomerized, $1.36 \mathrm{~g}, 1.51 \mathrm{mmol}$; isomerized, $0.273 \mathrm{~g}, 0.306 \mathrm{mmol}$ ) was dissolved in $\mathrm{CH}_{2} \mathrm{Cl}_{2}$ (non-isomerized $50 \mathrm{~mL}$; isomerized 20 $\mathrm{mL}$ ). Triethylamine (non-isomerized, $0.460 \mathrm{~g}, 4.55 \mathrm{mmol}$; isomerized, $0.092 \mathrm{~g}, 0.909 \mathrm{mmol}$ ) and a few crystals of DMAP were added. The reaction was cooled to $0{ }^{\circ} \mathrm{C}$, and methanesulfonyl chloride (non-isomerized, $0.347 \mathrm{~g}, 3.03 \mathrm{mmol}$; isomerized, $0.069 \mathrm{~g}, 0.606 \mathrm{mmol}$ ) was added dropwise. TLC indicated the reaction was complete within 20 minutes, and the reaction mixture was directly absorbed onto silica gel in preparation for column chromatography. Rapid column chromatography on silica gel (hexanes / ethyl acetate as eluent) yielded the amidomesylate (non-isomerized, $1.34 \mathrm{~g}, 1.37 \mathrm{mmol}, \mathrm{R}_{\mathrm{f}}=$ 0.42 , $50 \%$ ethyl acetate in hexanes; isomerized, $0.230 \mathrm{~g}, 0.235 \mathrm{mmol}, \mathrm{Rf}=0.55,50 \%$ ethyl acetate in hexanes) as yellow oils. Each amidomesylate was independently subjected to the following procedure to form the stable pyrrolidine. The amidomesylate (non-isomerized, $1.34 \mathrm{~g}, 1.37 \mathrm{mmol}$; isomerized, $0.230 \mathrm{~g}, 0.235 \mathrm{mmol}$ ) was dissolved in THF (non-isomerized, $50 \mathrm{~mL}$; isomerized, $20 \mathrm{~mL}$ ) and the solution cooled to -20 to $-30{ }^{\circ} \mathrm{C}$. This temperature is crucial because lower temperatures lead to slower reaction and decomposition, while higher temperatures lead to rapid formation of side products in some instances. KOtBu was added (non-isomerized, $0.269 \mathrm{~g}, 2.40 \mathrm{mmol}$; isomerized, $0.053 \mathrm{~g}, 0.47$ $\mathrm{mmol}$ ) and after 20 minutes TLC indicated that a small quantity of starting material remained, so 20 $\mathrm{mg}$ of KOtBu was added to each reaction, and the reactions were complete by TLC after 15 additional minutes. Saturated ammonium chloride solution was added, and the reaction was warmed to room temperature. The THF was removed under reduced pressure, and the resulting residue was partitioned between water and ethyl acetate, and the layers were separated. The aqueous layer was washed 3 times with ethyl acetate, and the combined organics dried with $\mathrm{MgSO}_{4}$. The solvent was removed under reduced pressure, and the resulting residue purified by column chromatography on silica gel (ethyl acetate / hexanes as eluent to yield 39 (non-isomerized) (1.10 g, $1.24 \mathrm{mmol}, 56 \%$ overall for 3 steps) and 39 (isomerized) $(0.180 \mathrm{~g}, 0.204 \mathrm{mmol}, 9 \%$ overall for 3 steps) for an overall yield of $65 \%$. The non-isomerized pyrrolidine was always the major product, but more of the isomerized product could be obtained if a larger excess of $\mathrm{SmI}_{2}$ was used.

39 (non-isomerized) was formed in a 50:43 mixture of rotamers. A single proton of the major rotamer was set to one for proton integration. $\mathrm{R}_{\mathrm{f}}=0.70,50 \%$ ethyl acetate in hexanes; ${ }^{1} \mathrm{H}-\mathrm{NMR}$ (600 MHz, $\left.\mathrm{CDCl}_{3}\right): \delta=7.66-7.65(\mathrm{~m}, 7.9 \mathrm{H}), 7.44-7.41(\mathrm{~m}, 4.1 \mathrm{H}), 7.39-7.24(\mathrm{~m}, 25.9 \mathrm{H}), 5.95$ (s, 0.9H), 5.91 (s,1.0H), 5.80 (s, 0.9H), 5.76 (s, 1.0H), 5.32 (s, 1.0H), 5.17 (s, 0.9H), 4.64 (d, J = 12.0 Hz, 1.1H), 4.56 (m, 1.9H), 4.50 (d, J = 12.0 Hz, 1.2H), 4.47 (s, 1.9H), 4.43 (s, 2.2H), 4.30-4.23 (m, 2.0H), 4.10 (dd, J = 8.4, 3.0 Hz, 0.9H), 3.86 (m, 1.2H), 3.76 (t, J = 9.0 Hz, 1.0H), 3.71-3.65 (m, 16.9H), 3.49 (t, J = 6.3 Hz, 2.0H), 3.39 (t, J = 6.3 Hz, 2.0H), 3.36- $3.29(\mathrm{~m}, 2.1 \mathrm{H}), 2.80-2.68(\mathrm{~m}, 5.0 \mathrm{H}), 2.51-2.46(\mathrm{~m}, 0.9 \mathrm{H})$, 2.44-2.39 (m, 1.1H), 2.35-2.30 (m, 1.1H), 2.22-2.17 (m, 2.0H), 1.91-1.83 (4.1H), 1.80-1.52 (10.2H), 1.06 (s, 8.0H), 1.05 (s, 9.0H) ; ${ }^{13} \mathrm{C}-\mathrm{NMR}\left(100 \mathrm{MHz}, \mathrm{CDCl}_{3}\right): \delta=172.8,172.4,172.3,171.9,166.5$, 166.2, 164.7, 163.8, 161.6, 153.4, 152.3, 138.4, 138.3, 135.3, 133.4, 133.3, 130.2, 129.4, 130.2, 129.4 (2 signals), 128.1, 128.0 (2signals), 127.6, 127.4, 127.3, 127.2, 127.1, 106.9, 105.9, 100.1, 99.4, 73.2, 73.0, 69.8, 69.5, 68.5, 66.5, 65.1, 62.4, 62.2, 60.0, 59.0, 52.4, 52.3, 51.0, 50.9, 35.8, 34.6, 33.6, 30.0, 29.1, 28.9, 26.6, 25.0, 24.9, 21.9, 21.7, 18.9; IR (thin film): 3069, 3055, 3049, 2950, 2932, 2857, $1745,1708,1654,1641,1473,1454,1429,1400,1362,1344,1231,1195,1167,1154,1111,1028$, 823, 812, 738, $702 \mathrm{~cm}^{-1}$; HRMS calc'd for $\mathrm{C}_{53} \mathrm{H}_{61} \mathrm{NO}_{9} \mathrm{Si}=883.4116$, found $=883.4125 ;[\alpha]_{\mathrm{D}}=-96.2$ $\left(c=2.35, \mathrm{CHCl}_{3}\right)$. 
39 (isomerized) was formed in a 100:37 mixture of rotamers. A single proton of the major rotamer was set to one for proton integration. $\mathrm{R}_{\mathrm{f}}=0.56,40 \%$ ethyl acetate in hexanes; ${ }^{1} \mathrm{H}-\mathrm{NMR}(600 \mathrm{MHz}$, $\left.\mathrm{CDCl}_{3}\right): \delta=7.66-7.64(\mathrm{~m}, 6.0 \mathrm{H}), 7.43-7.36(\mathrm{~m}, 9.2 \mathrm{H}), 7.37-7.24(\mathrm{~m}, 12.3 \mathrm{H}), 6.70(\mathrm{~s}, 1.0 \mathrm{H}), 6.67$ (s, $0.4 \mathrm{H}), 5.74(\mathrm{~s}, 1.0 \mathrm{H}), 5.74(\mathrm{~s}, 0.3 \mathrm{H}), 5.66(\mathrm{~s}, 1.0 \mathrm{H}), 5.62(\mathrm{~s}, 0.3 \mathrm{H}), 4.49$ (s, 2.1H), 4.43-4.42 (m, 1.6H), 4.40-4.38 (m, 3.2H), 4.12-4.09 (m, 0.4H), 3.82 (dd, J = 8.7, 3.9 Hz, 1.1H), 3.73 (s, 4.3H), 3.70 (app. t, $\mathrm{J}=6.0 \mathrm{~Hz}, 3.0 \mathrm{H}), 3.52$ (t, J = 6.6 Hz, 2.2H), 3.46 (s, 4.2H), 3.43-3.73 (m, 2.4H), 3.33 (dd, J = 9.3, 3.3 $\mathrm{Hz}, 0.4 \mathrm{~Hz}$ ), 3.04 (d, J = 13.8 Hz, 0.4H), 2.97 (dd, J = 14.4 Hz, 1.1H), 2.84-2.79 (m, 1.9H), $2.76(\mathrm{t}, \mathrm{J}=$ 8.1 Hz, 2.2H), 2.61-2.56 (m, 1.1H), 2.31-2.28 (m, 0.8H), 2.20-2.12 (m, 1.5H), 1.95-1.87 (m, 3.2H), 1.84-1.68 (m, 5.2H), 1.05-1.04 (m, 13.2H); ${ }^{13} \mathrm{C}-\mathrm{NMR}\left(100 \mathrm{MHz}, \mathrm{CDCl}_{3}\right): \delta=172.2,172.1,171.4$, 170.6, 166.7, 166.6, 165.8, 163.9, 163.1, 162.9, 152.3, 151.3, 138.3, 137.7, 137.1, 135.3, 133.5, 133.4, 129.4, 129.3, 128.3, 128.1 (2 signals), 127.6 (2 signals), 127.4, 127.3, 127.2, 126.2, 126.1, 106.9, 106.0, 105.6, 104.7, 73.1, 72.7, 72.6, 71.8, 70.6, 69.9, 69.7, 67.5, 65.6, 62.7, 62.5, 61.8, 61.4, 59.1, 58.9, 57.8, 52.5, 50.9 (2 signals), 38.1, 37.4, 34.3, 33.4, 30.3, 30.2, 29.2, 28.9, 26.6, 25.1, 25.0, 22.0, 21.8, 18.9; IR (thin film): 3070, 3031, 2951, 2932, 2858, 1738, 1723, 1638, 1460, 1454, 1429, 1407, 1384, 1361, 1289, 1241, 1221, 1196, 1111, 1061, 1028, 1010, 857, 824, 739, $702 \mathrm{~cm}^{-1}$; HRMS calc'd for $\mathrm{C}_{53} \mathrm{H}_{61} \mathrm{NO}_{9} \mathrm{Si}=883.4116$, found $=883.4125 ;[\alpha]_{\mathrm{D}}=-108.8\left(c=1.47, \mathrm{CHCl}_{3}\right)$.

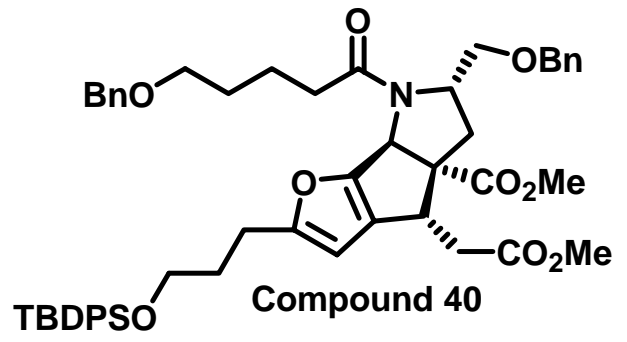

Both 39 (non-isomerized) and 39 (isomerized) yielded 20 in approximately the same yield, so a representative experimental procedure will be given using 39 (non-isomerized). Compound 39 (0.970 g, $1.10 \mathrm{mmol})$ and $\mathrm{NiCl}_{2} \bullet 6 \mathrm{H}_{2} \mathrm{O}(0.104 \mathrm{~g}$, $0.439 \mathrm{mmol})$ were dissolved in a mixture of methanol (100 $\mathrm{mL})$ and THF $(15 \mathrm{~mL}) . \mathrm{Na}_{2} \mathrm{CO}_{3}(0.600 \mathrm{~g})$ was added, and the reaction mixture cooled to $-50{ }^{\circ} \mathrm{C}$. $\mathrm{NaBH}_{4}(0.414 \mathrm{~g}, 10.97$ mmol, 10eq) was added, and after 20 minutes another 10 eq of $\mathrm{NaBH}_{4}$ was added. The reaction was stirred for another 30 minutes after which it turned black and hydrogen evolution started to occur. In some instances, it took more than an hour to initiate so it was warmed to $-40{ }^{\circ} \mathrm{C}$. Once the reaction initiated, the reaction was kept between -50 and $-55{ }^{\circ} \mathrm{C}$ and 40 more equivalents of $\mathrm{NaBH}_{4}(10$ eq every 20 minutes) was added (the isomerized sample needed 100 more equivalents). Stirring occurred for an additional two hours at $-50{ }^{\circ} \mathrm{C}$, after which the cold solution was rapidly filtered through a pad of celite to remove the black precipitate. The filter cake was washed with EtOAc, and $20 \mathrm{~mL}$ of water was added to the filtrate. The organic solvent was removed under reduced pressure, and to the resulting aqueous phase was added $30 \mathrm{~mL}$ of water and $50 \mathrm{~mL}$ of ethyl acetate. $20 \mathrm{~mL}$ of $5 \% \mathrm{HCl}$ was also added to destroy the emulsion. The layers were separated, and the aqueous layer extracted three times with EtOAc. The combined organics were washed with water then brine, and dried with $\mathrm{MgSO}_{4}$ The solvent was removed under reduced pressure to yield a crude oil that was purified by column chromatography on silica gel (ethyl acetate / hexanes as eluent) to yield $\mathbf{4 0}$ (0.642 g, 0.722 mmol, 67 $\%)$ as a yellow oil. The NMR shows that there may be $\sim 7 \%$ of what might be the diastereomer resulting from hydrogen delivery from the opposite face. The isomerized compound produces a slightly higher percentage (13\%) of the undesired diastereomer. Product formed as a 9:1 mixture of rotamers. A single proton of the major rotamer was set to one for proton integration. $\mathrm{R}_{\mathrm{f}}=0.70,50 \%$ ethyl acetate in hexanes; ${ }^{1} \mathrm{H}-\mathrm{NMR}\left(600 \mathrm{MHz} \mathrm{CDCl}_{3}\right)$ : $\delta=7.65-7.63(\mathrm{~m}, 5.1 \mathrm{H}), 7.43-7.40(\mathrm{~m}, 2.4 \mathrm{H})$, 7.33-7.22 (m, 13.2H), 5.84 (s, 0.1H), 5.75 (s, 1.0H), 5.71 (s, 0.1H), 5.67 (s, 1.0H), 4.49-4.48 (m, 2.4H), 4.47-4.43 (m, 1.6H), 4.40-4.38 (m, 1.4H), 4.27-4.24 (m, 1.1H), 3.69-3.65 (m, 6.3H), $3.56(\mathrm{~d}, \mathrm{~J}=$ 6.0Hz, 0.9H), 3.54-3.51 (m, 6.8H), 3.46-3.42 (m, 1.7H), 3.31-3.28 (m, 1.3H), 3.02 (d, J = $13.2 \mathrm{~Hz}$, 
0.1H), 2.96 (d, J = 13.8 Hz, 1.0H), 2.84 (dd, J = 15.9, 2.9 Hz, 0.2H), 2.79-2.74 (m, 1.3H), 2.70-2.65 (m, 2.4H), 2.59-2.54 (m, 1.4H), 2.46-2.41 (m, 1.3H), 2.20-2.15 (m, 2.4H), 1.85-1.78 (m, 5.0H), 1.751.70 (m, 2.9H), 1.04-1.03 (m, 12.0H); ${ }^{13} \mathrm{C}-\mathrm{NMR}\left(100 \mathrm{MHz}, \mathrm{CDCl}_{3}\right): \delta=172.5,172.2,171.6,161.5$, 153.3, 138.4, 137.9, 135.3, 133.6, 129.4, 128.2, 128.1, 127.6, 127.5, 127.4 (2 signals), 127.2 (2 signals), 103.7, 73.1, 72.7, 70.1, 69.0, 68.3, 62.7, 61.5, 57.0, 52.0, 51.5, 42.4, 38.7, 37.0, 34.3, 30.4, 29.6, 26.7, 25.1, 21.6, 19.0; IR (thin film): 3068, 3029, 2951, 2930, 2857, 1737, 1655, 1471, 1461, 1454, 1446, 1439, 1360, 1291, 1214, 1111, 1095, 1074, 883, 740, $701 \mathrm{~cm}^{-1}$; HRMS calc'd for $\mathrm{C}_{53} \mathrm{H}_{63} \mathrm{NO}_{9} \mathrm{Si}=885.4272$, found $=885.4286 ;[\alpha]_{\mathrm{D}}=-87.1\left(c=2.34, \mathrm{CHCl}_{3}\right)$.

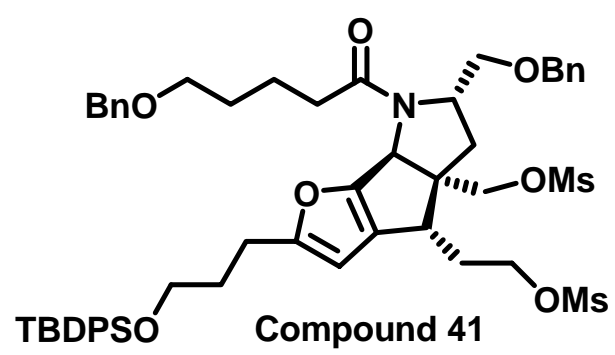

The preparation of bis-mesylate $\mathbf{4 1}$ was accomplished in two steps from $\mathbf{4 0}$ without purification of the intermediate diol. Compound 40 (1.31 g, $1.48 \mathrm{mmol})$ was dissolved in THF (100 $\mathrm{mL})$ and cooled to $0{ }^{\circ} \mathrm{C}$. Lithium aluminum hydride $(4.44$ mmol, $4.44 \mathrm{~mL}$ of a $1 \mathrm{M}$ solution in ether) was added dropwise and after 15 minutes TLC indicated complete consumption of the starting material $\left(\mathrm{R}_{\mathrm{f}}\right.$ of diol $=0.15$, $70 \%$ ethyl acetate in hexanes). Water ( $2 \mathrm{~mL}$ ) was cautiously added dropwise, and the reaction was stirred at $0{ }^{\circ} \mathrm{C}$ for 30 minutes, and then room temperature for 30 minutes. After this time a gelatinous precipitate formed, and this was removed by filtration through celite. The filter cake was washed with ethyl acetate, and the filtrate was dried with $\mathrm{MgSO}_{4}$. Removal of the solvent under reduced pressure yielded diol of sufficient purity $(1.19 \mathrm{~g})$ to be used in the next step. The crude diol from above was dissolved in $50 \mathrm{~mL}$ of $\mathrm{CH}_{2} \mathrm{Cl}_{2}$ and triethylamine (599 $\mathrm{mg}, 5.92 \mathrm{mmol}$ ) and DMAP (a few crystals) were added and the solution cooled to $0{ }^{\circ} \mathrm{C}$. Methanesulfonyl chloride (508 mg, 4.44 mmol) was added dropwise and after 1 hour TLC indicated complete conversion to the product with no evidence of the intermediate mono-mesylate. The reaction mixture was directly absorbed onto silica gel, and purified by column chromatography on silica (hexanes / ethyl acetate as eluent) to yield the bis-mesylate 41 (1.232 g, $1.35 \mathrm{mmol}, 85 \%$ for two steps) as a thick, yellow foam. There are some minor impurities present, one of which might be the other rotamer. A single proton of the major rotamer was set to one for proton integration. The impurities are removed in the next step. $R_{\mathrm{f}}=0.67$, 70\% ethyl acetate in hexanes;. ${ }^{1} \mathrm{H}-\mathrm{NMR}\left(600 \mathrm{MHz}, \mathrm{CDCl}_{3}\right)$ : $\delta=7.66-7.65$ (m, 4H), 7.44-7.37 (m, 6H), 7.35-7.24 (m, 10H), 5.92 (s, 1H), 4.94 (s, 1H), 4.57 (d, J = 11.4 Hz, 1H), 4.53-4.47 (m, 5H), 4.324.23 (m, 2H), 4.19-4.17 (m, 1H), 4.05 (dd, J = 10.2, 4.8 Hz, 1H), 3.70-3.66 (m, 2H), 3.61 (dd, J = 9.6, $2.4 \mathrm{~Hz}, 1 \mathrm{H}), 3.53$ (t, J = 6.3 Hz, 2H), 3.03 (s, 3H), 2.85 (dd, J = 12.0, 3.0 Hz, 1H), 2.69 (m, 6H), 2.582.53 (m, 1H), 2.41-2.31 (m, 2H), 2.06 (dd, J = 11.1, 5.7 Hz, 1H), 1.88-1.80 (m, 4H), 1.74-1.70 (m, 2H), 1.58-1.52 (m, 1H), 1.05 (s, 9H); ${ }^{13} \mathrm{C}-\mathrm{NMR}\left(100 \mathrm{MHz}, \mathrm{CDCl}_{3}\right): \delta=173.1,161.6,152.7,138.3$, 137.7, 135.1, 133.4, 129.3, 128.1, 127.9, 127.8, 127.7, 127.6, 127.5, 127.3, 127.2, 127.1, 103.9, 73.1, 72.5, 69.9, 69.6, 68.8, 67.6, 62.6, 61.5, 60.4, 56.8, 41.4, 37.2, 36.2, 34.3, 31.1, 30.3, 28.9, 26.5, 25.0, 21.6, 18.8; IR (thin film): 3029, 2932, 2857, 1653, 1428, 1409, 1357, 1176, 1111, 959, 917, 824, 740, $702 \mathrm{~cm}^{-1}$; HRMS calc'd for $\mathrm{C}_{53} \mathrm{H}_{67} \mathrm{NO}_{11} \mathrm{~S}_{2} \mathrm{Si}=985.3925$, found $=985.3898 ;[\alpha]_{\mathrm{D}}=-55.5(c=3.04$, $\left.\mathrm{CHCl}_{3}\right)$. 


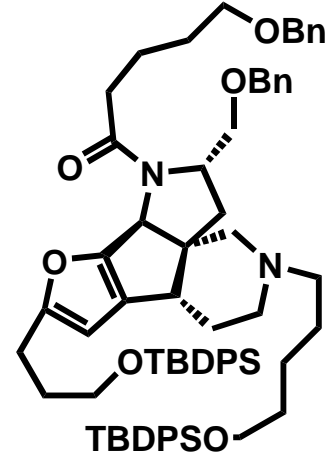

Compound 42

Bis-mesylate 41 (0.644 g, $0.662 \mathrm{mmol}$ ) was dissolved in THF (5 mL) and then absolute ethanol $(60 \mathrm{~mL})$ was added. 5-tert-butyldiphenylsiloxy-n-pentylamine ( $2.02 \mathrm{~g}, 5.98 \mathrm{mmol}$, see preparation below) was added, and the solution was refluxed for 32 hours, after which TLC indicated that some starting material remained. Additional amine $(0.250 \mathrm{~g}, 0.736 \mathrm{mmol})$ was added and the solution was refluxed an additional 22 hours, after which TLC indicated complete consumption of the starting mesylate. The solution was cooled to room temperature, and the solvent removed under reduced pressure. The residue was dissolved in EtOAc $(50 \mathrm{~mL})$, and $1 \mathrm{M} \mathrm{NaOH}(50 \mathrm{~mL})$ was added. The layers were separated, and the aqueous layer was washed two times with EtOAc, and the combined organics washed with brine and dried with $\mathrm{MgSO}_{4}$. Removal of the solvent under reduced pressure produced an oil that was purified by flash column chromatography on silica (ethyl acetate / hexanes as eluent) to yield 42 (0.600 g, $0.530 \mathrm{mmol}, 80 \%)$ as a colorless oil. $\mathrm{R}_{\mathrm{f}}=0.50$, 40\% ethyl acetate in hexanes; ${ }^{1} \mathrm{H}-\mathrm{NMR}\left(600 \mathrm{MHz}, \mathrm{CDCl}_{3}\right): \delta=7.67-7.64(\mathrm{~m}, 8 \mathrm{H})$, 7.427.35 (m, 12H), 7.32-7.28 (m, 8H), 7.25-7.22 (m, 2H), 5.76 (s, 1H), 4.89 (s, 1H), 4.58 (d, J = 11.7 Hz, 1H), 4.47 (s, 2H), 4.40 (d, J = 11.7 Hz, 1H), 4.20-4.17 (m, 1H), 3.91 (dd, J = 9.0, 3.6 Hz, 1H), 3.67 (t, J $=6.6 \mathrm{~Hz}, 2 \mathrm{H}), 3.64(\mathrm{t}, \mathrm{J}=6.6 \mathrm{~Hz}, 2 \mathrm{H}), 3.49$ (ddd, $\mathrm{J}=7.6,7.6,1.8 \mathrm{~Hz}, 2 \mathrm{H}), 3.44(\mathrm{t}, \mathrm{J}=8.7 \mathrm{~Hz}, 1 \mathrm{H})$, 3.00 (d, J = 12.0 Hz, 1H), 2.74-2.63 (m, 4H), 2.53-2.48 (m, 1H), 2.43 (dd, J = 9.6, 6.6 Hz, 1H), 2.272.16 (m, 2H), 2.11 (dd, J = 13.2, $9.6 \mathrm{~Hz}, 1 \mathrm{H}), 2.03-2.01(\mathrm{~m}, 2 \mathrm{H}), 1.94-1.90$ (m, 2H), 1.83 (p, J = 7.6 Hz, 2H), 1.78 (p, J = 7.6 Hz, 2H), 1.69 (p, J = 7.6 Hz, 2H), 1.54 (p, J = 7.6 Hz, 2H), 1.37-1.27 (m, 6H), 1.05 (s, 9H), 1.04 (s, 9H); ${ }^{13} \mathrm{C}-\mathrm{NMR}\left(100 \mathrm{MHz}, \mathrm{CDCl}_{3}\right): \delta=173.8,160.6,153.9,138.6,138.4,135.5$, 134.0, 133.8, 132.0, 129.5 (2 signals), 128.2, 127.8, 127.6, 127.5, 127.3, 102.9, 73.0, 72.8, 70.6, 70.3, 63.9, 63.4, 62.8, 61.8, 58.7, 58.6, 56.9, 51.8, 39.6, 39.0, 34.6, 32.6, 32.4, 30.7, 29.4, 26.8, 26.7, 25.3, 23.8, 21.7, 19.2 (2 signals) (one $\mathrm{sp}^{3}$ and four $\mathrm{sp}^{2}$ carbons are missing, presumably due to overlap); IR (thin film): 2930, 2901, 2896, 2857, 1651, 1472, 1462, 1454, 1428, 1408, 1112, 824, 738, $701 \mathrm{~cm}^{-1}$; HRMS calc'd for $\mathrm{C}_{72} \mathrm{H}_{90} \mathrm{~N}_{2} \mathrm{O}_{6} \mathrm{Si}_{2}=1134.6347$, found $=1134.6337$

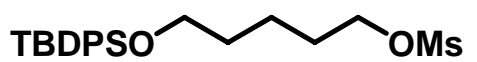

Amine Precursor 1
Mono-TBDPS protected 1,5-pentanediol (16.50 g, $48.17 \mathrm{mmol})$ and triethylamine ( $6.33 \mathrm{~g}, 62.62 \mathrm{mmol}$ ) were added to $\mathrm{CH}_{2} \mathrm{Cl}_{2}$ and cooled to $0{ }^{\circ} \mathrm{C}$. Methanesulfonyl chloride (6.62 g, $\left.57.80 \mathrm{mmol}\right)$ was added dropwise, and the reaction stirred for 1 hour at $0{ }^{\circ} \mathrm{C}$. The reaction was warmed to room temperature and washed with $5 \% \mathrm{HCl}(100 \mathrm{~mL})$, water and then brine. The organic layer was dried with $\mathrm{MgSO}_{4}$ and the solvent removed under reduced pressure. The resulting oil was purified by flash column chromatography on silica gel (ethyl acetate / hexanes as eluent) to yield Amine Precursor 1 (17.10 g, $40.65 \mathrm{mmol}, 84 \%)$ as a colorless oil. $\mathrm{R}_{\mathrm{f}}=0.66,40 \%$ ethyl acetate in hexanes; ${ }^{1} \mathrm{H}-\mathrm{NMR}(600 \mathrm{MHz}$, $\left.\mathrm{CDCl}_{3}\right): \delta=7.76-7.65(\mathrm{~m}, 4 \mathrm{H}), 7.43(\mathrm{tt}, \mathrm{J}=7.2,1.8 \mathrm{~Hz}, 2 \mathrm{H}), 7.40-7.37(\mathrm{~m}, 4 \mathrm{H}), 4.21(\mathrm{t}, \mathrm{J}=7.6 \mathrm{~Hz}$, 2H), 3.67 (t, J = 7.6 Hz, 2 H), 2.98 (s, 3H), 1.76-1.72 (m, 2H), 1.61-1.56 (m, 2H), 1.52-1.47 (m, 2H), 1.05 (s, 9H); ${ }^{13} \mathrm{C}-\mathrm{NMR}\left(100 \mathrm{MHz}, \mathrm{CDCl}_{3}\right): \delta=135.5,133.8,129.5,127.6,69.9,63.3,37.2,31.7,28.7$, 26.8, 21.7, 19.1; IR (thin film): 3072, 2932, 2858, 1473, 1428, 1390, 1357, 1112, 952, 823, 742, 703 $\mathrm{cm}^{-1}$; HRMS [M+H] calc'd for $\mathrm{C}_{22} \mathrm{H}_{23} \mathrm{O}_{4} \mathrm{SSi}=421.1869$, found $=421.1873$. 


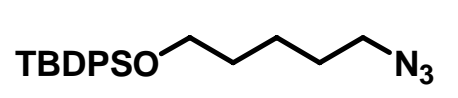

Amine Precursor 2

Mesylate Amine Precursor 1 (17.10 g, $40.65 \mathrm{mmol})$ and sodium azide (6.61 g, $101.62 \mathrm{mmol}$ ) were added to DMF $(171 \mathrm{~mL})$ and water $(22 \mathrm{~mL})$ and the resulting mixture heated to $50{ }^{\circ} \mathrm{C}$ for 15 hours. After cooling to room temperature, the reaction mixture was poured into water $(500 \mathrm{~mL})$ and the aqueous layer extracted 3 times with ether. The combined organic layers were washed with water and brine and then dried with $\mathrm{MgSO}_{4}$. Removal of the solvent under reduced pressure yielded pure Amine Precursor 2 (13.99 g, $38.05 \mathrm{mmol}, 94 \%)$ as a colorless oil. $\mathrm{R}_{\mathrm{f}}=0.86,30 \%$ ethyl acetate in hexanes; ${ }^{1} \mathrm{H}-\mathrm{NMR}$ (600 $\left.\mathrm{MHz}, \mathrm{CDCl}_{3}\right): \delta=7.67-7.66(\mathrm{~m}, 4 \mathrm{H}), 7.44-7.41(\mathrm{~m}, 2 \mathrm{H}), 7.40-7.37(\mathrm{~m}, 4 \mathrm{H}), 3.67(\mathrm{t}, 7.6 \mathrm{~Hz}, 2 \mathrm{H}), 3.24$ (t, J = 7.6 Hz, 2H), 1.61-1.55 (m, 4H), 1.48-1.43 (m, 2H), 1.05 (s, 9H); ${ }^{13} \mathrm{C}-\mathrm{NMR}\left(150 \mathrm{MHz}, \mathrm{CDCl}_{3}\right)$ : $\delta=135.5,133.9,129.5,127.6,63.5,51.3,31.9,28.5,26.8,23.0,19.2$; IR (thin film): 3072, 2933, 2859, 2096, 1472, 1428, 1390, 1362, 1265, 1112, 998, 824, 741, $701 \mathrm{~cm}^{-1}$; HRMS [M+H] calc'd for $\mathrm{C}_{21} \mathrm{H}_{30} \mathrm{~N}_{3} \mathrm{OSi}=368.2158$, found $=368.2162$.

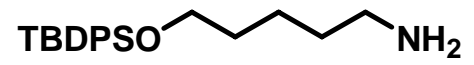

5-tert-butyldiphenylsiloxy-n-pentylamine
Azide Amine Precursor 2 (13.80 g, 37.54 mmol) was dissolved in ether $(450 \mathrm{~mL})$ and placed in a water bath. Lithium aluminum hydride powder (1.43 g, $37.54 \mathrm{mmol})$ was added in three portions over 15 minutes, and the reaction was stirred at room temperature for 1.5 hours. The reaction was cooled in an ice bath and quenched with water $(20 \mathrm{~mL}$, cautiously at first) and stirred at room temperature for 20 minutes. $1 \mathrm{M}$ sodium hydroxide solution $(300 \mathrm{~mL})$ was added and the layers separated. The aqueous layer was washed 2 more times with ether, and the organic washes combined. The organic washes had a significant amount of gelatinous precipitate/water present, so it was filtered through celite, and then the layers were separated. The organic layer was dried with $\mathrm{MgSO}_{4}$ and concentrated under reduced pressure to yield the desired amine (12.35 g, $36.4 \mathrm{mmol}$, 97\%) as a colorless oil. $\mathrm{R}_{\mathrm{f}}=$ baseline, $30 \%$ ethyl acetate in hexanes; ${ }^{1} \mathrm{H}-\mathrm{NMR}\left(600 \mathrm{MHz}, \mathrm{CDCl}_{3}\right): \delta=$ 7.68-7.66 (m, 4H), 7.43-7.41 (m, 2H), 7.39-7.36 (m, 4H), 3.66 (t, J = 6.6 Hz, 2H), 2.66 (t, J = 6.6 Hz, $2 \mathrm{H}), 1.57$ (p, J = 6.6 Hz, 2H), 1.43-1.36 (m, 4H), 1.05 (s, 9H); ${ }^{13} \mathrm{C}-\mathrm{NMR}\left(150 \mathrm{MHz}, \mathrm{CDCl}_{3}\right.$ ): $\delta=$ 135.4, 134.0, 129.4, 127.5, 63.7, 42.1, 33.4, 32.3, 26.8, 22.9, 19.1; IR (thin film): 3071, 2931, 2858, 1589, 1473, 1428, 1389, 1307, 1112, 823, 739, $701 \mathrm{~cm}^{-1}$; HRMS - calc'd for $\mathrm{C}_{21} \mathrm{H}_{31} \mathrm{NOSi}=341.2175$, found $=341.2179$

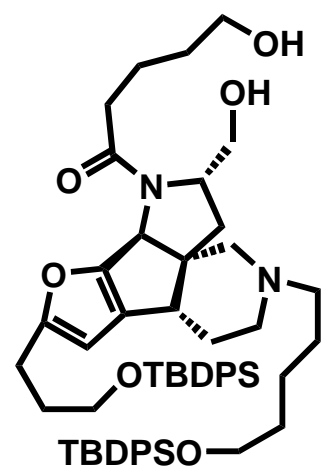

Compound 43

Compound 42 (885 mg, $0.781 \mathrm{mmol}$ ) was dissolved in methylene chloride (90 $\mathrm{mL}$ ) and the solution cooled to $-78{ }^{\circ} \mathrm{C}$. Boron trichloride $(6.0 \mathrm{~mL}$ of a $1 \mathrm{M}$ solution in methylene chloride, $6.0 \mathrm{mmol}$ ) was added dropwise and the reaction stirred for 3.5 hours at $-78{ }^{\circ} \mathrm{C}$. Saturated aqueous $\mathrm{NaHCO}_{3}(10 \mathrm{~mL})$ was added (slowly at first) and the reaction stirred at $-78{ }^{\circ} \mathrm{C}$ for 20 minutes, then removed from the cold bath and allowed to warm to room temperature. The reaction mixture was added to $1 \mathrm{M} \mathrm{NaOH}(30 \mathrm{~mL})$ and the layers separated. The aqueous layer was washed 3 times with methylene chloride and the combined organics washed with brine and dried with $\mathrm{MgSO}_{4}$. The solvent was removed under reduced pressure and the resulting residue purified by flash column chromatography on silica gel (hexanes /ethyl acetate to methanol / ethyl acetate) to yield diol 43 (343 $\mathrm{mg}, 0.360 \mathrm{mmol}, 45 \%$ ) as a yellow oil along with a mixture of products $(302 \mathrm{mg}$ ) that was mostly the mono-debenzylated compound. This mixture was 
resubjected to the above condition using $30 \mathrm{~mL}$ of methylene chloride and $2.0 \mathrm{~mL}$ of $\mathrm{BCl}_{3}$ solution to yield an additional $102 \mathrm{mg}$ of $\mathbf{4 3}$ to bring the total yield after 1 recycle to $445 \mathrm{mg}, 0.467 \mathrm{mmol}, 60 \%$. $\mathrm{R}_{\mathrm{f}}=0.47$, 8\% methanol in ethyl acetate; ${ }^{1} \mathrm{H}-\mathrm{NMR}\left(600 \mathrm{MHz}, \mathrm{CDCl}_{3}\right): \delta=7.66-7.65(\mathrm{~m}, 8 \mathrm{H}), 7.42-$ 7.36 (m, 12H), 5.80 (s, 1H), 5.57 (d, J = 9.0 Hz, 1H), 4.91 (s, 1H), 4.18-4.12 (m, 1H), 3.72-3.59 (m, $8 \mathrm{H}$ ), 2.82 (d, J = 12.0 Hz, 1H), 2.80-2.75 (m, 1H), 2.70 (dd, J = 7.8, $7.2 \mathrm{~Hz}, 2 \mathrm{H}), 2.60-2.50$ (m, 3H), 2.32-2.29 (m, 3H), 2.04-2.00 (m, 3H), 1.88-1.76 (m, 5H), 1.67-1.51 (m, 6H), 1.47-1.42 (m, 2H), 1.401.34 (m, 3H), 1.06 (s, 9H), 1.04 (s, 9H); IR (thin film): 3500-3100 broad, 3075, 2937, 2859, 1646, $1624,1420,1105,823 \mathrm{~cm}^{-1}$; HRMS - calc'd for $\mathrm{C}_{58} \mathrm{H}_{78} \mathrm{~N}_{2} \mathrm{O}_{6} \mathrm{Si}_{2}=954.5398$, found $=954.5351$.

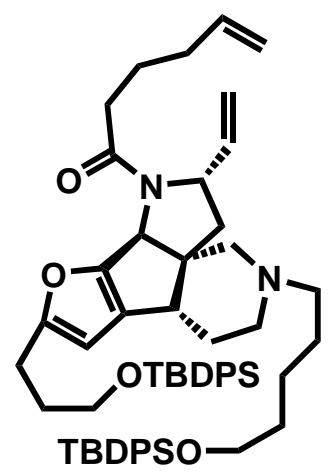

Compound 45

Bis-alkene $\mathbf{4 5}$ was prepared in two steps from diol $\mathbf{4 3}$ without purification of the intermediate bis-aldehyde. Diol 43 (210 $\mathrm{mg}, 0.22 \mathrm{mmol})$ was dissolved in DMSO (25 mL) and IBX (566 mg, $1.98 \mathrm{mmol}$ ) was added. The reaction was stirred under argon for 2.5 hours after which TLC indicated complete consumption of the starting material and no mono-alcohol. The reaction mixture was poured into $200 \mathrm{~mL}$ of saturated $\mathrm{NaHCO}_{3}$, and the aqueous layer was extracted four times with ether. The combined organics were washed once with water and dried with $\mathrm{MgSO}_{4}$. The solvent was removed under reduced pressure to yield a yellow oil $\left(215 \mathrm{mg}\right.$ ) that was used directly in the next step. $\mathrm{MePPh}_{3} \mathrm{I}$ $(1.07 \mathrm{~g}, 2.64 \mathrm{mmol})$ was added to THF $(40 \mathrm{~mL})$ and the slurry cooled to $0{ }^{\circ} \mathrm{C}$. KOtBu $(0.247 \mathrm{~g}, 2.20 \mathrm{mmol})$ was added and the mixture stirred at $0{ }^{\circ} \mathrm{C}$ for 15 minutes. A THF solution of the bis-aldehyde generated above $(10 \mathrm{~mL})$ was added rapidly via cannula and the mixture stirred for 15 minutes, after which TLC indicated complete consumption of the starting material. Water $(5 \mathrm{~mL})$ was then added and the THF was removed under reduced pressure. To the resulting residue was added water $(30 \mathrm{~mL}), 1 \mathrm{M} \mathrm{NaOH}(5 \mathrm{~mL})$, and EtOAc $(20 \mathrm{~mL})$. The layers were separated, and the aqueous layer was extracted 3 times with EtOAc. The combined organics were dried with $\mathrm{MgSO}_{4}$, and the solvent was removed under reduced pressure to yield a crude residue that was purified by column chromatography on silica gel (hexanes / ethyl acetate as eluent) to yield bis-alkene 45 (110 mg, $0.116 \mathrm{mmol}, 52 \%$ for two steps) as a pale yellow oil. $\mathrm{R}_{\mathrm{f}}=0.61,50 \%$ ethyl acetate in hexanes; Proton NMR showed that the product was a 10:3 mixture of rotational isomers. A single proton of the major rotamer was set to one for proton integration. ${ }^{1} \mathrm{H}-\mathrm{NMR}$ (600 $\mathrm{MHz}, \mathrm{CDCl}_{3}$ ): $\delta=7.67-7.66(\mathrm{~m}, 12.0 \mathrm{H}), 7-44-7.36$ (m, $\left.18.6 \mathrm{H}\right), 5.89-5.75(\mathrm{~m}, 4.3 \mathrm{H}), 5.25(\mathrm{~s}, 0.3 \mathrm{H})$, 5.14-5.02 (m, 5.3H), 4.98-4.89 (m, 2.0H), 4.59-4.56 (m, 1.0H), 4.37-4.34 (m, 0.3H), 3.70-3.65 (m, 6.5H), 3.11 (d, J = 12.6 Hz, 1H), 2.95 (d, J = 12.0 Hz, 0.3H), 2.79-2.67 (m, 5.7H), 2.59-2.52 (m, 1.7H), 2.44-2.27 (m, 6.8H), 2.18-2.11 (m, 2.6H), 2.09-2.03 (m, 3.0H), 1.98-1.92 (m, 3.2H), 1.89-1.82 (m, 6.3H), 1.78-1.74 (m, 1.9H), 1.60-1.55 (m, 4.1H), 1.46-1.21 (m, 17.3H, includes grease), 1.06-1.05 (m, 28.7H); ${ }^{13} \mathrm{C}-\mathrm{NMR}$ (100 MHz, $\mathrm{CDCl}_{3}$ ): $\delta=173.1$ (2 signals), 160.5, 154.0, 140.0, 138.4, 135.5, 134.0, 133.8, 131.7, 129.5 (2 signals), 127.5 (2 signals), 114.8, 113.7, 102.9, 102.2, 63.8, 63.0, 62.9, 59.4, 59.0, 58.5, 54.0, 42.3, 38.4, 33.9, 33.7, 33.3, 33.1, 32.4, 30.7, 29.6, 26.8, 25.4, 24.3, 24.2, 23.7, 19.2 (2 signals); IR (thin film): 3069, 3048, 2933, 2857, 2804, 2769, 1652, 1464, 1430, 1406, 1110, 910, 823, $740 \mathrm{~cm}^{-1}$; HRMS calc'd for $\mathrm{C}_{68} \mathrm{H}_{78} \mathrm{~N}_{2} \mathrm{O}_{4} \mathrm{Si}_{2}=946.5500$, found $=946.5462$. 


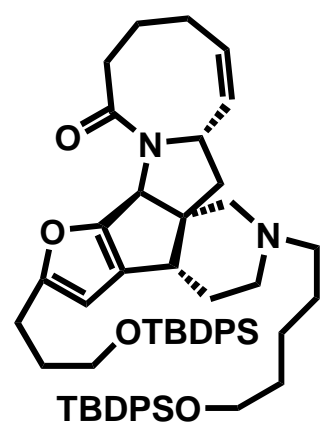

Compound 46

Compound 45 (61 mg, $0.064 \mathrm{mmol}$ ) was dissolved in $\mathrm{CH}_{2} \mathrm{Cl}_{2}$ and Grubbs1 $1^{\text {st }}$ generation catalyst (6 mg, $0.00707 \mathrm{mmol}, 11 \mathrm{~mol} \%$ ) was added. The reaction was evacuated and backfilled with argon five times, and then refluxed for 2 hours, after which TLC indicated complete consumption of the starting material. The reaction mixture was directly absorbed onto silica, and purified by column chromatography on silica gel (hexanes / ethyl acetate as eluent) to yield 46 (44 $\mathrm{mg}, 0.048 \mathrm{mmol}, 75 \%$ ) as an orange film. $\mathrm{R}_{\mathrm{f}}=0.26,40 \%$ ethyl acetate in hexanes; ${ }^{1} \mathrm{H}-\mathrm{NMR}\left(600 \mathrm{MHz}, \mathrm{CDCl}_{3}\right)$ : $\delta=7.67-766(\mathrm{~m}, 8 \mathrm{H}), 7.43-7.36(\mathrm{~m}$, 12H), 5.76 (s, 1H), 5.62-5.58 (m, 1H), 5.41 (d, J = $12.6 \mathrm{~Hz}, 1 \mathrm{H}), 5.18$ (s, 1H), 4.50 (d, J = 9.6 Hz, 1H), 3.69 (t, J = 6.6 Hz, 2H), 3.65 (t, J = 6.6 Hz, 2H), 3.02 (d, J = 12.0 Hz, 1H), 2.75 (t, J = 7.8 Hz, 2H), 2.66-2.59 (m, 2H), 2.43-2.40 (m, 2H), 2.37-2.28 (m, 3H), 2.19-2.16 (m, 1H), 2.05-1.87 (m, 8H), 1.78 (d, J = 12.7 Hz, 1H), 1.71-1.66 (m, 1H), 1.58 (p, J = 6.6 Hz, 2H), 1.40-1.32 (m, 6H), 1.049 (s, 9H), 1.046 (s, 9H); ${ }^{13} \mathrm{C}-\mathrm{NMR}$ (150 MHz, $\mathrm{CDCl}_{3}$ ): $\delta=173.1,160.5,155.1,135.4,134.7,134.0,133.8,131.2,129.4$ (2 signals), 127.5 (2 signals), 125.8, 102.4, 63.7, 63.2, 63.0, 59.8, 58.2, 56.2, 52.1, 43.9, 38.2, 32.4, 32.3, 30.6, 29.5, 26.8, 26.7, 26.1, 25.3, 23.4, 22.6, 19.1, 19.09 (one $\mathrm{sp}^{2}$ and two $\mathrm{sp}^{3}$ signals missing, presumably due to overlap); IR (thin film): 3071, 2931, 2902, 2857, 1653, 1647, 1472, 1462, 1458, 1427, 1406, 1399, 1110, 823, 740; HRMS calc'd for $\mathrm{C}_{58} \mathrm{H}_{74} \mathrm{~N}_{2} \mathrm{O}_{4} \mathrm{Si}_{2}=918.5187$, found $=918.5154$.

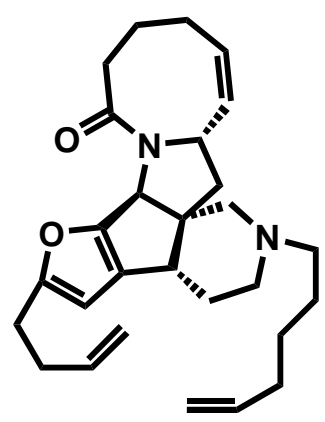

Compound 49

Since the Nakadomarin A produced by this route could not be separated from the E-isomer, the following procedure was not optimized. Diene $\mathbf{4 9}$ was prepared in 3 steps from 46. Data is not given for the intermediate diol or dial because the TBAF used for silyl removal co-elutes with the product and a pure sample could not be obtained. The low yield for this sequence may be attributed to the residual TBAF contamination. For the bis-amide $\mathbf{5 7}$ it was found that acidic methanol deprotection lead to a higher overall yield for the desilylation, oxidation, Wittig sequence. Compound 46 (147 mg, $0.160 \mathrm{mmol}$ ) was dissolved in THF (25 mL) and TBAF (0.64 mL of a 1M solution in THF, $0.64 \mathrm{mmol})$ added. After 7 hours the starting material was consumed and there was no indication of the mono-TBDPS compound remaining by TLC, so the THF was removed under reduced pressure and the residue dissolved in methylene chloride. The material was pre-absorbed on silica and subjected to chromatography on silica gel (methanol / ethyl acetate as eluent) to yield the TBAF contaminated diol (71 mg for mixture, $\sim 20-25 \%$ by weight TBAF), $\mathrm{R}_{\mathrm{f}}=0.15$ (25\% methanol in ethyl acetate). Half of this mixture (35 mg) was dissolved in methylene chloride (10 $\mathrm{mL})$ and cooled to $0{ }^{\circ} \mathrm{C}$. Dess-Martin periodinane $(168 \mathrm{mg}, 0.395 \mathrm{mmol})$ was added and the reaction stirred at $0{ }^{\circ} \mathrm{C}$ for 1 hour and then room temperature for 2 hours $\left(\mathrm{R}_{\mathrm{f}}\right.$ of dial $=0.42(25 \%$ methanol in ethyl acetate)$)$. Saturated aqueous $\mathrm{NaHCO}_{3}(3 \mathrm{~mL})$ and $\mathrm{Na}_{2} \mathrm{~S}_{2} \mathrm{O}_{3}(3 \mathrm{~mL})$ were added and the mixture stirred vigorously for 30 minutes. The layers were separated, and the aqueous layer extracted 2 times with methylene chloride. The combined organics were dried and the solvent removed under reduced pressure to yield $35 \mathrm{mg}$ of crude product. Crude NMR analysis indicated that the correct product was formed, but the ratio of TBAF to product has increased slightly. A solution of the crude oxidation product in THF (3 mL) was added to a slurry of Wittig ylide (prepared by stirring t-BuOK (89 mg, $0.793 \mathrm{mmol}$ ) and $\mathrm{MePPh}_{3} \mathrm{I}$ (383 mg, $0.948 \mathrm{mmol}$ ) in THF (8 mL) for 30 minutes) via cannula at $0{ }^{\circ} \mathrm{C}$. After 10 minutes TLC indicated complete consumption of the starting material, and water $(2 \mathrm{~mL})$ was 
added. The THF was removed under reduced pressure, and water (3 mL) and ethyl acetate (5 mL) were added. The layers were separated and the aqueous layer was extracted 3 times with ethyl acetate and the combined organics washed with water and then dried with $\mathrm{MgSO}_{4}$. Removal of the solvent under reduced pressure and purification of the residue by flash column chromatography on silica gel (hexanes / ethyl acetate as eluent) yielded diene 49 (8 $\mathrm{mg}, 0.0184 \mathrm{mmol}, 23 \%$ for $3 \mathrm{steps}$ ) as a yellow oil. The yields for this sequence were variable and range from $20-30 \% . R_{\mathrm{f}}=0.33,100 \%$ ethyl acetate; ${ }^{1} \mathrm{H}-\mathrm{NMR}\left(600 \mathrm{MHz}, \mathrm{CDCl}_{3}\right): \delta=5.87-5.74(\mathrm{~m}, 3 \mathrm{H}), 5.66-5.62(\mathrm{~m}, 1 \mathrm{H}), 5.42(\mathrm{~d}, \mathrm{~J}=12.0 \mathrm{~Hz}, 1 \mathrm{H})$, 5.20 (s, 1H), 5.03 (dd, J = 17.1, 1.5 Hz, 1H), 4.99-4.96 (m, 2H), 4.92 (d, J = $10.2 \mathrm{~Hz}, 1 \mathrm{H}), 4.51$ (d, $\mathrm{J}=$ $10.2 \mathrm{~Hz}, 1 \mathrm{H}$ ), 3.05 (d, J = 12.6 Hz, 1H), 2.74-2.60 (m, 4H), 2.44-2.32 (m, 7H), 2.20-2.18 (m, 1H), 2.06-1.95 (m, 6H), 1.89 (d, J = 12.0 Hz, 1H), 1.79 (d, J = 12.0 Hz, 1H), 1.74-1.69 (m, 2H), 1.39-1.35 (m, 5H).

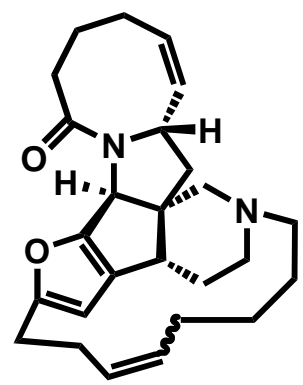

Mixture 50

Diene 49 (18 mg, $0.0414 \mathrm{mmol}$ ) was dissolved in $\mathrm{CH}_{2} \mathrm{Cl}_{2}$ (200 mL) and to this solution was added Grubbs First Generation Catalyst (13 mg, 0.0164 mmol, 40 mol\%). The reaction flask was evacuated and back filled with argon five times, and then refluxed for 20 hours. The solvent was removed under reduced pressure, and a crude NMR indicated that the reaction had gone to completion and that the ratio of $E: Z$ isomers was approximately 5:3. The reaction mixture was then subjected to column chromatography on silica gel, (hexanes / ethyl acetate to methanol / ethyl acetate as eluent) to yield a mixture of the E-and Z-isomers (12 $\mathrm{mg}, 0.0295 \mathrm{mmol}, 71 \%$ combined) as a brown film in a ratio that was similar to the crude. Attempted separation of the isomers by chromatography on silica, silver impregnated preparative TLC, and HPLC on both standard and reversed phase columns failed in our hands, so the mixture would be subjected to Red-Al reduction in hopes that the final product could be separated. $\mathrm{R}_{\mathrm{f}}$ of mixture $\mathbf{5 0}=0.20$ ( $20 \%$ methanol in ethyl acetate).

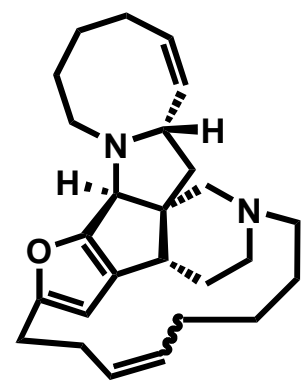

(+)-Nakadomarin A and $E$-isomer

Mixture 50 was subjected to the procedure of Nishida (Angew. Chem. Int. Ed. 2004, 43, 2020). A solution of Mixture 50 (8.0 mg, $0.0197 \mathrm{mmol}$ ) in toluene (5 $\mathrm{mL}$ ) was cooled to $0{ }^{\circ} \mathrm{C}$. Red-Al (80 $\mu \mathrm{L}$ of a $65 \%$ solution in toluene) was added and stirring continued for 10 minutes at this temperature. The reaction was then heated to reflux for 3 hours, then quenched at $-30{ }^{\circ} \mathrm{C}$ with saturated aqueous Rochelle's salt ( $3 \mathrm{~mL}$ ). After warming to room temperature, the mixture was stirred vigorously for 1 hour, then ethyl acetate ( $5 \mathrm{~mL}$ ) was added, and vigorous stirring continued for an additional hour. The layers were separated, and the aqueous layer extracted 4 times with ethyl acetate. The combined organics were washed with saturated aqueous Rochelle's salt, twice with brine and the solvent removed under reduced pressure. The residue was subjected to column chromatography on silica gel (methanol / ethyl acetate as eluent) to produce a mixture of nakadomarin A and the $\boldsymbol{E}$-isomer (6.0 mg, $0.0153 \mathrm{mmol}, 75 \%$ combined) as a pale brown film. The ratio of the compounds was 5:4 E-isomer:Nakadomarin A after the reduction. As with mixture 50, we were unable to successfully separate the two compounds. $\mathrm{R}_{\mathrm{f}}$ of mixture $=0.16$ (80 \% methanol in ethyl acetate). A ${ }^{1} \mathrm{H}-\mathrm{NMR}$ of the mixture is included in the spectral section. 


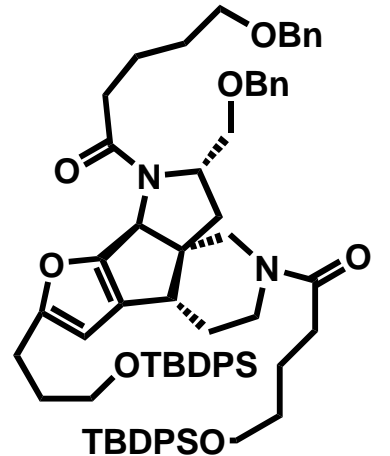

Compound 53

Compound 53 was prepared in two steps from bis-mesylate 41, without purification of the intermediate secondary amine. Bis-mesylate 41 (0.950 g, $0.992 \mathrm{mmol}$ ) was dissolved in a minimum volume of tetrahydrofuran ( 3 $\mathrm{mL}$ ) and transferred to a pressure tube. A solution of ammonia in absolute ethanol (20 $\mathrm{mL}$ of an approximately 2.8 M solution) was then added, the head space purged with argon, and the tube heated to $85{ }^{\circ} \mathrm{C}$ for 13 hours. The solution was then cooled to room temperature, and the solvent removed under reduced pressure to yield a crude yellow residue. To this residue was added water $(50 \mathrm{~mL}), 1$ molar $\mathrm{NaOH}(50 \mathrm{~mL})$ and ethyl acetate $(100 \mathrm{~mL})$ and the layers separated. The aqueous layer was washed twice with ethyl acetate and the combined organics washed with water and brine and dried with $\mathrm{MgSO}_{4}$. Removal of the solvent under reduce pressure produced a yellow oil that was of high enough purity to be used directly in the next step. NMR showed approximately $8 \%$ of the other diastereomer still present from the double bond reduction. $\mathrm{R}_{\mathrm{f}}$ of intermediate secondary amine $=0.51,50 \%$ methanol in ethyl acetate. The crude amine (750 mg of mixture) was dissolved in methylene chloride (30 mL) and triethylamine (388 mg, $3.83 \mathrm{mmol}$ ) was added. The solution was cooled to $0{ }^{\circ} \mathrm{C}$, and 5-tertbutyldiphenylsiloxy-n-pentanoyl chloride (953 mg, $2.39 \mathrm{mmol}$, see preparation below) was added dropwise as a solution in methylene chloride $(15 \mathrm{~mL})$, and the reaction kept at $0{ }^{\circ} \mathrm{C}$ for 2 hours before being stirred at room temperature for 16 hours. The solvent was then removed under reduced pressure, and the residue dissolved in ether $(100 \mathrm{~mL})$. Water $(100 \mathrm{~mL})$ was added and the layers separated. The aqueous layer was washed 2 times with ether and the combined organics washed once with $5 \% \mathrm{HCl}, 1$ $\mathrm{M} \mathrm{NaOH}$, water and then brine and dried with $\mathrm{MgSO}_{4}$. The solvent was removed under reduced pressure and the resulting residue purified by column chromatography on silica gel (hexanes / ethyl acetate as eluent) to yield bis-amide 53 (847 mg, $0.739 \mathrm{mmol}$, 77\% over two steps) as a yellow viscous oil. Compound was formed in what appears to be a 5:3:1 mixture of rotamers. A single proton of the major rotamer was set to one for proton integration $\mathrm{R}_{\mathrm{f}}=0.54,50 \%$ ethyl acetate in hexanes; ${ }^{1} \mathrm{H}-\mathrm{NMR}$ (600 MHz, $\left.\mathrm{CDCl}_{3}\right): \delta=7.66-7.64(\mathrm{~m}, 14.5 \mathrm{H}), 7.43-7.28(\mathrm{~m}, 34.5 \mathrm{H}), 7.26-7.22(\mathrm{~m}, 6.0 \mathrm{H}), 5.75$ (s, 1.4H), 5.72 (s, 0.2H), 4.71 (s, 1H), 4.70 (s, 0.5H), 4.58 (d, J = 11.4 Hz, 0.2H), 4.54 (s, 1.4H), 4.50-4.44 (m, 6.0H), 4.34-4.26 (m, 2.3H), 3.99-3.95 (m, 1.8H), 3.85 (d, J = 13.8Hz, 1H), 3.68-3.66 (m, 5.9H), 3.61 (dd, J = 6.0, 6.6 Hz, 2H), 3.54-3.40 (m, 7.9H), 3.35-3.27 (m, 1.6H), 3.18-3.10 (m, 1.9H), 2.83 (d, $\mathrm{J}=10.8 \mathrm{~Hz}, 0.2 \mathrm{H}), 2.80-2.67(\mathrm{~m}, 7.4 \mathrm{H}), 2.51-2.44(\mathrm{~m}, 1.8 \mathrm{H}), 2.31-2.00$ (m, 10.2H), 1.86-1.57 (m, 24.2H), 1.47 (p, J = 7.2 Hz, 2.4H), 1.05-1.03 (m, 32.7H), 0.89-0.84 (m, 1.8H); ${ }^{13} \mathrm{C}-\mathrm{NMR}(100 \mathrm{MHz}$, $\left.\mathrm{CDCl}_{3}\right): \delta=172.9,172.8,172.7,172.5,161.8,161.7,153.8,153.3,138.4,138.3,138.1,137.6,135.2$, 133.6, 133.5, 133.4, 129.3 (2 signals), 128.1, 128.0, 127.5 (2 signals), 127.3 (2 signals), 127.2 (2 signals), 127.1, 127.0, 102.6, 102.5, 73.1, 72.9, 72.5 (2 signals), 69.9 (2 signals), 69.6, 63.4. 63.3 (3 signals), 62.5 (2 signals), 60.5, 59.9, 57.5, 57.2, 47.2, 44.7, 41.7, 40.8, 40.7, 39.3, 39.1, 38.9, 36.8, 35.0, 34.3, 34.2, 33.4, 32.7, 32.0, 31.9, 31.8, 31.7, 30.4 (2 signals), 29.1, 26.6, 25.9, 25.0 (2 signals), 21.7, 21.5, 21.2, 21.1, 21.0, 18.9; IR (thin film): 3070, 3048, 3030, 2931, 2893, 2857, 1647, 1472, 1462, 1454, 1428, 1414, 1392, 1111, 823, 740, $702 \mathrm{~cm}^{-1}$; HRMS calc'd for $\mathrm{C}_{72} \mathrm{H}_{88} \mathrm{~N}_{2} \mathrm{O}_{7} \mathrm{Si}_{2}=$ 1148.6130, found $=1148.6178$. Attempts to determine the optical rotation of 22 were unsuccessful, as solutions with concentrations as high as 1.70 in $\mathrm{CHCl}_{3}$, did not produce appreciable readings.

5-tert-butyldiphenylsiloxy-n-pentanoic acid was prepared in three steps according to the following procedure: 1,5-pentanediol (18.94 g, $180.55 \mathrm{mmol}$ ) was dissolved in N,N-dimethylformamide (100 $\mathrm{mL}$ ) and imidazole (0.248 $\mathrm{g}, 3.64 \mathrm{mmol})$ and DMAP (a few crystals) were added. Tertbutyldiphenylsilylchloride (4.97 g, $18.10 \mathrm{mmol}$ ) was added via syringe and the reaction stirred at room 
temperature for 18 hours. The reaction was poured into water $(500 \mathrm{~mL})$ and extracted 5 times with ether. The combined organics were washed 5 times with water ( $50 \mathrm{~mL}$ portions), then once with brine and dried with $\mathrm{MgSO}_{4}$. Removal of the solvent under reduced pressure produced the mono-silylated alcohol (5.26 g, $15.36 \mathrm{mmol}$, 84\% crude yield) as a yellow oil. This material was of sufficient purity to be used without directly in the next step. The TBDPS-protected monoalcohol (5.00 g, $14.60 \mathrm{mmol})$ from above was dissolved in DMSO (50 mL) under argon, and to this was added IBX (6.10 g, 21.35 mmol). After 2 hours the reaction was complete by TLC, and the reaction was added to water (500 $\mathrm{mL}$ ) and extracted 5 times with ether. The combined organics were washed 3 times with water, once with brine, and dried with $\mathrm{MgSO}_{4}$. Removal of the solvent under reduced pressure produced the aldehyde (4.84 g, $14.21 \mathrm{mmol}, 97 \%$ crude yield) as a yellow oil. The material was of sufficient purity to be used in the next step without further purification. The crude aldehyde (4.84 g, $14.21 \mathrm{mmol}$ ) was dissolved in tert-butanol $(90 \mathrm{~mL})$ and water $(30 \mathrm{~mL})$, cooled to $0{ }^{\circ} \mathrm{C}$ and 2-methyl-2-butene $(5.98 \mathrm{~g}$, $85.26 \mathrm{mmol}$ ) added. A solution of sodium chlorite (2.57 g, $3.21 \mathrm{~g}$ of $80 \%$ reagent, $28.42 \mathrm{mmol}$ ) and sodium dihydrogen phosphate $(7.84 \mathrm{~g}, 56.82 \mathrm{mmol})$ in water $(60 \mathrm{~mL})$ was then added dropwise. After 1 hour the reaction was complete by TLC, and water $(150 \mathrm{~mL})$ was added. Acetic acid was added to adjust the $\mathrm{pH}$ to 5 . The reaction mixture was then washed 3 times with ether and dried with $\mathrm{MgSO}_{4}$. The solvent was removed under reduced pressure to produce an oil that was purified by flash column chromatography (hexanes / ethyl acetate as eluent) to yield the acid (4.28 g, $12.02 \mathrm{mmol}$, 84\% over 2 steps) as a yellow solid. This material was identical spectroscopically with that reported by Jacobi, P.A.; Li, Y.; Org. Lett. 2003, 5, 701.

5-tert-butyldiphenylsiloxy-n-pentanoyl chloride - 5-tert-butyldiphenylsiloxy-n-pentanoic acid (0.909 g, $2.39 \mathrm{mmol}$ ) was dissolved in $20 \mathrm{~mL}$ of toluene, and 3 drops of DMF was added. Oxalyl chloride $(0.425 \mathrm{~g}, 3.35 \mathrm{mmol})$ was then added dropwise, and the reaction stirred at room temperature for 30 minutes. The reaction was then heated to $50{ }^{\circ} \mathrm{C}$ for 1 hour. After cooling to room temperature, the toluene was removed under reduced pressure to produce the acid chloride as an orange oil. This acid chloride was dissolved in $\mathrm{CH}_{2} \mathrm{Cl}_{2}(15 \mathrm{~mL})$ and used directly in the reaction above.

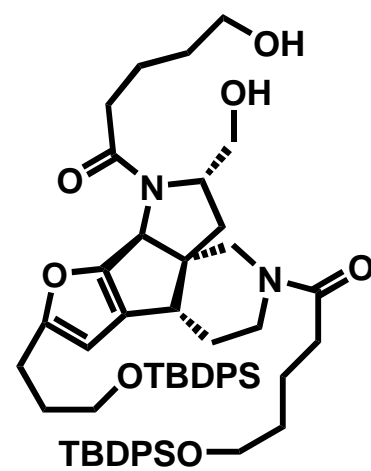

Compound 54

Bis-amide 53 (700 mg, $0.610 \mathrm{mmol}$ ) was dissolved in methylene chloride (70 $\mathrm{mL}$ ) and the solution cooled to $-78{ }^{\circ} \mathrm{C}$. Boron trichloride (3.66 mmol, 3.66 $\mathrm{mL}$ of a $1 \mathrm{M}$ solution in methylene chloride) was added dropwise, and the reaction was allowed to warm slowly to $-50{ }^{\circ} \mathrm{C}$ (about 1.5 hours). The reaction was maintained at $-50{ }^{\circ} \mathrm{C}$ for two hours, and then cooled to $-78{ }^{\circ} \mathrm{C}$. A saturated solution of sodium bicarbonate $(4 \mathrm{~mL})$ was then cautiously added, and the reaction stirred at $-78{ }^{\circ} \mathrm{C}$ for 20 minutes, after which it was removed from the cooling bath, and allowed to warm to room temperature. The reaction mixture was added to water $(20 \mathrm{~mL})$ and $1 \mathrm{M} \mathrm{NaOH}(20 \mathrm{~mL})$ and layers were separated. The aqueous layer was extracted twice with methylene chloride, and the combined organics washed twice with brine and dried with $\mathrm{MgSO}_{4}$. The solvent was removed under reduced pressure to yield a crude residue that was purified by column chromatography on silica gel (hexane / ethyl acetate to methanol / ethyl aceate as eluent) to yield diol 54 (420 mg, $0.434 \mathrm{mmol}, 71 \%)$ as a yellow oil/foam. Diol 54 was formed as a 5:2 ratio of rotamers. A single proton of the major rotamer was set to one for proton integration. $\mathrm{R}_{\mathrm{f}}=0.17,100 \%$ ethyl acetate; ${ }^{1} \mathrm{H}-\mathrm{NMR}\left(600 \mathrm{MHz}, \mathrm{CDCl}_{3}\right)$ : $\delta=7.67-7.64(\mathrm{~m}$, 12H). 7.44-7.35 (m, 18H), 5.78 (s, 1.4 H), 5.46 (br. s, 1H), 4.84 (s, 1H), 4.75 (s, 0.4H), 4.19 (d, J = 
13.2 Hz, 1H), 4.06-4.04 (m, 0.4H), 3.83 (d, J = 11.4 Hz, 0.4H), 3.72-3.59 (m, 13.2H), 3.53 (dd, $\mathrm{J}=$ 10.2, $10.2 \mathrm{~Hz}, 0.4 \mathrm{~Hz}), 3.49-3.42$ (m, 1.4H), 3.33-3.29 (m, 2.1H), 3.26-3.19 (m, 1.4H), 2.88-2.84 (m, 1.4H), 2.80-2.61 (m, 6.6H), 2.57-2.52 (m, 0.7H), 2.42-2.29 (m, 1.6H), 2.24-2.08 (m, 4.6H), 1.99 (dd, J $=7.2,13.2 \mathrm{~Hz}, 1 \mathrm{H}), 1.87-1.55(\mathrm{~m}, 19.2 \mathrm{H}), 1.41-1.35(\mathrm{~m}, 0.5 \mathrm{H}), 1.06-1.04(\mathrm{~m}, 26.3 \mathrm{H}), 0.98-0.86(\mathrm{~m}$, $1.8 \mathrm{H})$; ${ }^{13} \mathrm{C}-\mathrm{NMR}\left(100 \mathrm{MHz}, \mathrm{CDCl}_{3}\right): \delta=174.7,173.3,162.4,153.0,135.0,133.7,133.6,129.8$, 129.5 (2 signals), 127.5 (2 signals), 102.5, 65.1, 64.8, 63.4, 62.7, 62.2, 61.8, 58.4, 48.5, 44.7, 41.2, 40.7, 40.1, 34.3, 33.4, 32.9, 32.1, 32.0, 31.9, 31.8, 30.5, 26.8, 25.8, 25.3, 21.5, 21.2, 20.8, 19.11, 19.07; IR (thin film): 3415 (broad), 3071, 2953, 2950, 2932, 2895, 2859, 1635, 1628, 1473, 1428, 1112, 1070, 823, 741, 703, $688 \mathrm{~cm}^{-1}$; HRMS [M+H] calc'd for $\mathrm{C}_{58} \mathrm{H}_{77} \mathrm{~N}_{2} \mathrm{O}_{7} \mathrm{Si}_{2}=969.5260$, found = 969.5238. Attempts to determine the optical rotation of $\mathbf{2 3}$ were unsuccessful, as solutions with concentrations as high as 2.1 in $\mathrm{CHCl}_{3}$, did not produce appreciable readings.

Compound 56 was prepared in two steps from the diol without purification of the intermediate bisaldehyde, as the crude aldehyde was of high purity. Subsequent purification of the aldehyde did not lead to increased yields over the two step sequence.

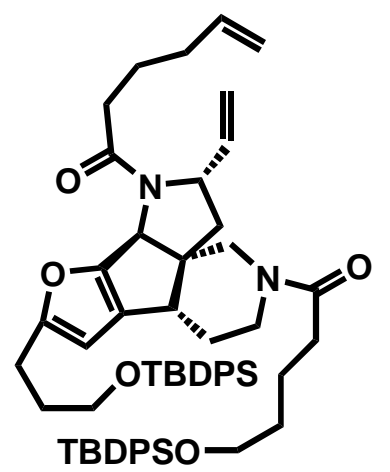

Compound 56

Diol 54 (378 mg, $0.391 \mathrm{mmol}$ ) was dissolved in dimethyl sulfoxide (20 mL) and o-Iodoxybenzoic Acid (IBX) (1.33 g, $4.69 \mathrm{mmol}$ ) was added and the reaction stirred for 13 hours. TLC indicated the presence of the intermediate mono-aldehyde, so more IBX was added (200 mg, $0.701 \mathrm{mmol}$ ) and the reaction stirred for an additional 4 hours. TLC indicated complete conversion to the bis-aldehyde $\left(\mathrm{R}_{\mathrm{f}}=0.61,100 \%\right.$ ethyl acetate), and the reaction mixture was poured into saturated sodium bicarbonate $(120 \mathrm{~mL})$ and extracted 5 times with ether. The combined organics were washed twice with water and once with brine, dried with $\mathrm{MgSO}_{4}$ and the solvent removed under reduced pressure to produce crude aldehyde (347 mg) as a yellow oil. The resulting crude product was divided into three equivalent portions ( 115 mg each) for the Wittig, because on rare occasions the reaction can lead to decomposition. In this instance all three reactions were successful, so they were combined afterwards for work up and column. The procedure will be given for one of the three portions. The crude bis-aldehyde from above was dissolved in THF (4 mL). The ylide solution in toluene (4 mL) (prepared by stirring $\mathrm{MePPh}_{3} \mathrm{Br}$ (488 mg, $1.38 \mathrm{mmol}$ ) and $\mathrm{KOtBu}$ (127 mg, $1.14 \mathrm{mmol}$ ) in toluene ( $4 \mathrm{~mL}$ ) for 1.5 hours) was added quickly via a large bore cannula, and after 10 minutes TLC indicated consumption of the starting material. Water (2 mL) was added, and at this point all three reactions were combined. The THF/toluene was removed under reduced pressure, and water $(10 \mathrm{~mL})$ and ethyl acetate $(10 \mathrm{~mL})$ were added to the residue. The layers were separated, and the aqueous layer was washed 3 times with ethyl acetate. The combined organics were washed once with water, then with brine, and dried with $\mathrm{MgSO}_{4}$. The solvent was then removed under reduced pressure, yielding a residue that was purified by chromatography on silica gel (hexanes / ethyl acetate as eluent) to yield diene 56 (124 mg, $0.129 \mathrm{mmol}, 36 \%$ ) as a yellow oil. Diene 56 was formed as a 5:4:3 mixture of identifiable rotamers. A single proton of the major rotamer was set to one for proton integration. $\mathrm{R}_{\mathrm{f}}=0.68,60 \%$ ethyl acetate in hexanes; ${ }^{1} \mathrm{H}-\mathrm{NMR}\left(600 \mathrm{MHz}, \mathrm{CDCl}_{3}\right): \delta=$ 7.67-7.65 (m, 24.4H), 7.43-7.36 (m, 36.7H), 5.98-5.72 (m, 9.4H), 5.28 (d, J = 10.2 Hz, 1H), 5.20-4.90 (m, 13.3H), 4.81 (s, 0.8H), 4.80-4.78 (m, 1.4H), 4.68-4.64 (m, 0.8H), 4.52-4.48 (m, 0.6H), 4.47-4.45 (m, 1H), 4.23 (d, J = 13.2 Hz, 0.8H), 4.00 (d, J = 13.8 Hz, 1H), 3.74-3.67 (m, 13.4H), 3.58-3.50 (m, 3.6H), 3.43 (d, J = 13.8 Hz, 1H), 3.37-3.31 (m, 2.6H), 3.24-3.12 (m, 3.1H), 2.87-2.68 (m, 10.6H), 
2.64-2.62 (m, 0.7H), 2.55-2.48 (m, 1.7H), 2.31-2.04 (m, 23.9H), 1.97-1.57 (m, 33.8H), 1.06-1.04 (m, $54.0 \mathrm{H}$ ); Due to the number or rotamers present, the carbon spectrum was not resolved well. Only the peaks that were clearly identifiable will be reported. ${ }^{13} \mathrm{C}-\mathrm{NMR}\left(100 \mathrm{MHz}, \mathrm{CDCl}_{3}\right): \delta=172.9,172.8$, 172.7, 172.6, 172.5, 172.4, 172.3, 172.1, 162.1, 162.0, 161.8, 155.2, 154.4, 153.9, 153.3, 138.2, 138.1, 138.0, 135.7, 135.4, 135.4, 135.0, 129.6, 129.4, 129.3, 127.7, 127.4, 127.2, 114.9, 114.7 (2 signals), 102.8, 102.7, 102.6, 102.5, 102.0, 101.8, 63.6, 63.4, 63.1, 62.8, 62.7, 62.6, 61.3, 60.7, 60.1, 59.9, 59.3, 58.3, 57.9, 33.4, 33.2, 33.1, 33.0, 32.9, 32.8, 32.2, 32.0, 31.9, 30.5 (2 signals), 29.5, 26.7, 24.1, 23.9, 19.1; IR (thin film): 3072, 2953, 2931, 2898, 2858, 1653, 1648, 1473, 1462, 1443, 1427, 1419, 1274, 1185, 1112, 998, 913, 823, 741, 702, $688 \mathrm{~cm}^{-1}$; HRMS [M+H] calc'd for $\mathrm{C}_{60} \mathrm{H}_{77} \mathrm{~N}_{2} \mathrm{O}_{5} \mathrm{Si}_{2}=961.5371$, found $=961.5388$.

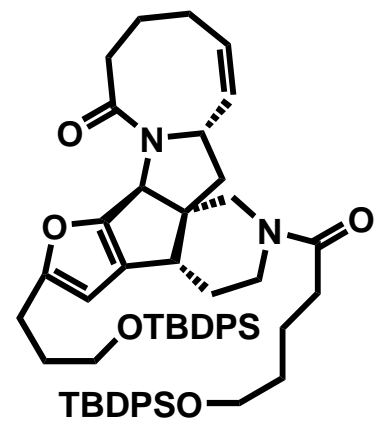

Compound 57

Alkene 56 (80 mg, $0.0834 \mathrm{mmol}$ ) was dissolved in methylene chloride (120 $\mathrm{mL}$ ) and to this solution was added Grubbs $2^{\text {nd }}$ generation catalyst (14 mg, $0.0167 \mathrm{mmol}, 20 \mathrm{~mol} \%$ ). The reaction flask was evacuated and backfilled with argon four times and then refluxed for 2.5 hours, after which TLC indicated complete consumption of the starting material. The solvent was removed under reduced pressure, and the residue purified by flash column chromatography (hexanes / ethyl acetate as eluent) to yield azocine 57 (65 $\mathrm{mg}, 0.0696 \mathrm{mmol}, 84 \%$ ) as a beige foam. The compound was produced as a 5:3 mixture of rotamers. A single proton of the major rotamer was set to one for proton integration. $\mathrm{R}_{\mathrm{f}}=0.26,50 \%$ ethyl acetate in hexanes; ${ }^{1} \mathrm{H}-\mathrm{NMR}$ $\left(600 \mathrm{MHz}, \mathrm{CDCl}_{3}\right): \delta=7.66-7.65(\mathrm{~m}, 13.4 \mathrm{H}), 7.43-7.35(\mathrm{~m}, 20.1 \mathrm{H})$, 5.82$5.76(\mathrm{~m}, 2.6 \mathrm{H}), 5.70-5.65(\mathrm{~m}, 0.6 \mathrm{H}), 5.49-5.44(\mathrm{~m}, 1.6 \mathrm{H}), 4.96(\mathrm{~s}, 0.6 \mathrm{H}), 4.89(\mathrm{~s}, 1 \mathrm{H}), 4.61-4.57$ (m, $1.6 \mathrm{H}), 4.13$ (d, J = 14.4 Hz, 1H), 3.73-3.64 (m, 8.1H), 3.51-3.48 (m, 1H), 3.43 (d, J = 14.4 Hz, 0.6H), 3.37 (d, J = 13.8 Hz, 1H), 3.32-3.25 (m, 1.6H), 3.21-3.17 (m, 1H), 2.78-2.59 (m, 7.3H), 2.40-1.87 (m, 21.5H), 1.74-1.60 (m, 11.8H), 1.05-1.04 (m, 30.0H); ${ }^{13} \mathrm{C}-\mathrm{NMR}$ (150 MHz, $\left.\mathrm{CDCl}_{3}\right): \delta=173.4,173.1$, 172.6, 171.8, 162.0, 161.9, 155.0, 154.3, 135.3, 134.1, 133.7, 133.6, 133.3, 129.3 (2 signals), 128.3, 127.8, 127.6, 127.4, 127.2, 102.2, 102.1, 63.4, 63.3, 62.8, 62.7, 59.5, 57.3, 57.1, 47.7, 43.6, 43.2, 42.7, 40.8, 40.1, 39.7, 39.4, 33.2, 32.9, 32.5, 32.2, 32.0, 30.4, 29.4, 27.1 26.6, 26.5, 26.4, 25.3, 22.8, 22.6, 21.3, 21.0, 18.98, 18.96; IR (thin film): 3071, 3049, 3014, 2999, 2953, 2931, 2895, 2858, 1656, 1650, 1645, 1471, 1461, 1428, 1409, 1270, 1112, 823, 741, $703 \mathrm{~cm}^{-1}$; HRMS [M+H] calc'd for $\mathrm{C}_{58} \mathrm{H}_{73} \mathrm{~N}_{2} \mathrm{O}_{5} \mathrm{Si}_{2}=933.5058$, found $=933.5393$.

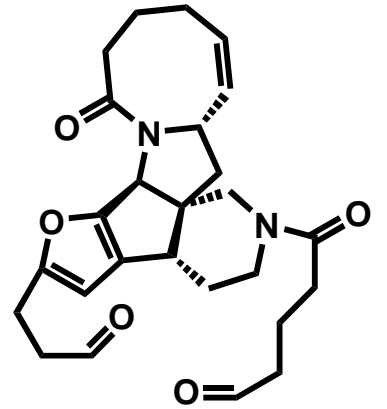

Compound 59

Compound 57 (40 mg, $0.0428 \mathrm{mmol}$ ) was divided into four approximately equal portions $(10 \mathrm{mg})$ for the next two reactions, due to the Dess-Martin producing an unidentifiable and inseparable by-product on rare occasions. The procedure will be given for one of these four equivalent reactions, and all operations were performed independently. To 57 was added methanol (3 $\mathrm{mL}$ ). Acidic methanol (10 drops, prepared by adding 20 drops of acetyl chloride to $5 \mathrm{~mL}$ of methanol) was added, and the reaction monitored by TLC $\left(\mathrm{R}_{\mathrm{f}}=0.25\right.$, 20\% methanol in ethyl acetate for desired diol). More $\mathrm{HCl}$ solution was added as follows, after 45 minutes 5 drops, after 2 hours 5 drops, after 3 hours 7 drops. After 4.5 hours TLC indicated complete consumption of the starting material and no evidence of the mono-silylated compound. Solid sodium bicarbonate 
was added to neutralize the acid, and the solution was filtered through a plug of cotton wool. The salt remaining in the flask was washed with methanol and methylene chloride. Removal of the solvent under reduced pressure yielded a solid film that was the result of a minor amount of salt being soluble in the methanol, so to this was added methylene chloride and then it was filtered again through a plug of cotton. Removal of the solvent under reduced pressure yielded a yellow oil, (approximately $10 \mathrm{mg}$ ), that was of very high purity by NMR, except for the presence of the cleaved silyl groups.

Again, the oxidation with Dess-Martin periodinane was performed in four separate batches, and the procedure for one will be given. To the crude diol (10 mg, (5 mg, $0.0107 \mathrm{mmol}$ of which is diol)) was added methylene chloride $(4 \mathrm{~mL})$. The solution was cooled to $0{ }^{\circ} \mathrm{C}$, and to this was added DessMartin periodinane (23 $\mathrm{mg}, 0.0535 \mathrm{mmol}$ ) and the reaction maintained at this temperature for 30 minutes. The reaction was then stirred at room temperature for 2.5 hours, after which TLC indicated complete consumption of the starting material and no evidence of the unknown by-product $\left(\mathrm{R}_{\mathrm{f}}=0.43\right.$, $35 \%$ methanol in ethyl acetate). Saturated sodium bicarbonate (1 mL) and saturated sodium thiosulfate $(1 \mathrm{~mL})$ was then added and the reaction stirred for one hour. At this point, since there was no evidence of by-product formation in any of the four reactions, they were combined for work up and purification. The layers were separated, and the aqueous layer washed 3 times with methylene chloride. The combined organics were washed with saturated sodium thiosulfate and brine, dried with $\mathrm{MgSO}_{4}$ and concentrated under reduced pressure. The compound was then purified by column chromatography (ethyl acetate / hexanes to methanol / ethyl acetate as eluent) to yield bis-aldehyde 59 (14 mg, $0.0316 \mathrm{mmol}, 70 \%$ for 2 steps) as a yellow oil. Bis-aldehyde 59 was formed as a 5:3 mixture of rotamers. A single proton of the major rotamer was set to one for proton integration. $R_{f}=0.43$, 35\% methanol in ethyl acetate; ${ }^{1} \mathrm{H}-\mathrm{NMR}\left(600 \mathrm{MHz}, \mathrm{CDCl}_{3}\right): \delta=9.78(\mathrm{~s}, 1.4 \mathrm{H}), 9.75(\mathrm{~s}, 1.4 \mathrm{H}), 5.84-5.83$ (m, 1.4H), 5.80-5.75 (m, 1.7H), 5.51-5.46 (m, 1.6H), 4.95 (s, 0.6H), $4.86(\mathrm{~s}, 1.0 \mathrm{H}), 4.65-4.58(\mathrm{~m}$, 1.6H), 4.19 (d, J = 13.2 Hz, 1H), 3.66 (d, J = 13.2 Hz, 0.6H), 3.50-3.46 (m, 0.6H), 3.42 (d, J = 13.8 Hz, 1H), 3.35-3.26 (m, 2.2H), 3.23-3.17 (m, 1.6H), 2.97-2.95 (m, 3.3H), 2.82-2.70 (m, 5.0H), 2.66-2.48 $(\mathrm{m}, 5.7 \mathrm{H}), 2.39-1.89(\mathrm{~m}, 21.0 \mathrm{H}), 1.80-1.60(\mathrm{~m}, 5.5 \mathrm{H}), 0.88-0.83(\mathrm{~m}, 1 \mathrm{H}) ;{ }^{13} \mathrm{C}-\mathrm{NMR}(100 \mathrm{MHz}$, $\left.\mathrm{CDCl}_{3}\right): \delta=202.3$, 202.1, 201.1, 201.0, 173.7, 173.5, 172.0, 171.1, 159.9, 159.8, 155.7, 155.0, 134.1, 133.3, 128.6, 128.1, 127.9, 127.6, 103.3, 63.4, 59.7, 59.6, 57.5, 57.3, 47.7, 43.8, 43.4, 43.2, 43.0, 41.8 (2 signals), 40.9, 40.4, 39.9, 39.5, 32.6, 32.4, 32.2, 32.1, 29.6, 27.0, 26.6, 26.5, 23.0, 22.8, 21.5, 17.3, 17.2; IR (thin film): 2928, 2893, 2872, 2728, 1718, 1646, 1642, 1457, 1437, 1420, 1277, 1270, 1158, 1075, 1054, 1031, 936, 933, 798, $732 \mathrm{~cm}^{-1}$; HRMS calc'd for $\mathrm{C}_{26} \mathrm{H}_{32} \mathrm{~N}_{2} \mathrm{O}_{5}=452.2311$, found $=$ 452.2303.

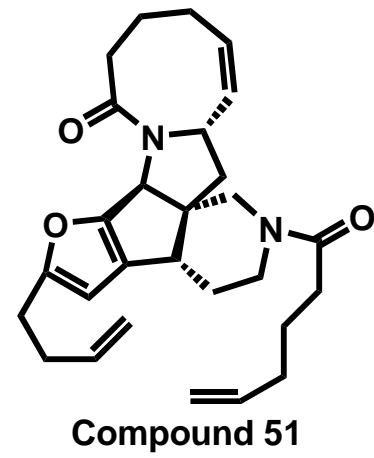

Compound 59 was divided into three equivalent portions ( 4 mg each) for the Wittig, and they were combined for work up and column after each reaction was determined to be successful. The procedure for one of these $4 \mathrm{mg}$ samples will be given. Compound 59 was dissolved in THF $(0.5 \mathrm{~mL})$. A solution of the Wittig ylide (prepared by stirring $\mathrm{MePPh}_{3} \mathrm{Br}$ (330 mg, 0.923 $\mathrm{mmol})$ and $\mathrm{KOtBu}(80 \mathrm{mg}, 0.713 \mathrm{mmol})$ for 1.5 hours in toluene $(3 \mathrm{~mL})$ ) was added via cannula until the reaction was yellow/brown $(\sim 2 \mathrm{~mL})$. Upon initial addition of the ylide solution, the reaction turns bright red/purple, and if addition is stopped at this stage, little to no product can be isolated. After 10 minutes, water $(2 \mathrm{~mL})$ was added to the reaction. At this stage all three reactions were combined, and the organic solvent removed under reduced pressure. Ethyl acetate (10 $\mathrm{mL}$ ) and water ( $5 \mathrm{~mL}$ ) was added to the residue and the layers were separated. The aqueous layer was 
extracted three times with ethyl acetate, and the combined organics were washed with water, brine, dried with $\mathrm{MgSO}_{4}$, and concentrated under reduced pressure. The residue was purified by column chromatography on silica gel (hexanes/ethyl acetate as eluent) to yield the desired bis-alkene $\mathbf{5 1}$ which was contaminated with triphenylphosphine oxide (23 mg total mass of mixture). The triphenylphosphine oxide did not affect the following metathesis step, but a small portion ( 1 mg) of 51 was purified by preparative TLC (4\% methanol in $\mathrm{CH}_{2} \mathrm{Cl}_{2}$, eluted 4 times) for characterization by ${ }^{1} \mathrm{H}-\mathrm{NMR}$, IR and HRMS. A ${ }^{13} \mathrm{C}-\mathrm{NMR}$ was run with the triphenylphosphine oxide present. Due to the limited material, not all peaks were observed. A comparison of the peaks observed for ${ }^{13} \mathrm{C}-\mathrm{NMR}$ with those reported by Nishida is presented in the following table. A visual comparison of the ${ }^{1} \mathrm{H}$ - and ${ }^{13} \mathrm{C}$ spectra is in the spectral section of the supporting information. Bis-alkene $\mathbf{5 1}$ was formed as a 5:3 mixture of rotamers. A single proton of the major rotamer was set to one for proton integration. $\mathrm{R}_{\mathrm{f}}=$ 0.38, 100\% ethyl acetate; ${ }^{1} \mathrm{H}-\mathrm{NMR}\left(600 \mathrm{MHz}, \mathrm{CDCl}_{3}\right): \delta=5.86-5.74(\mathrm{~m}, 5.9 \mathrm{H}$, contains furan singlets at $5.83(0.6 \mathrm{H})$ and $5.82(1 \mathrm{H})), 5.50(\mathrm{dd}, \mathrm{J}=12.0,9.6 \mathrm{~Hz}, 1.6 \mathrm{H}), 5.07-4.95(\mathrm{~m}, 6.7 \mathrm{H}), 4.90(\mathrm{~s}, 1 \mathrm{H}), 4.64$ (d, J = 9.6 Hz, 0.6H), 4.59 (d, J = 9.0 Hz, 1H), 4.17 (d, J = 14.4 Hz, 1H), 3.68 (d, J = $13.8 \mathrm{~Hz}, 0.6 \mathrm{H})$, 3.52-3.46 (m, 0.6H), 3.46 (d, J = 13.8 Hz, 0.6H), 3.37-3.34 (m, 2H), 3.29-3.21 (m, 1.6H), 2.74-2.62 (m, 6.5H), 2.40-1.99 (m, 24.5H), 1.80-1.56 (m, 8.6H), 0.89-0.81 (m, 4.1H); ${ }^{13} \mathrm{C}-\mathrm{NMR}(100 \mathrm{MHz}$, $\left.\mathrm{CDCl}_{3}\right): \delta=173.6,172.8,161.9,155.4,154.6,138.2$, 137.54, 137.49, 134.4, 133.5, 128.0, 127.9, 127.5, 115.16, 115.1, 102.5, 102.4, 63.57, 59.7, 57.6, 57.4, 43.9, 43.5, 43.1, 41.1, 40.1, 33.4, 33.3, 32.9, 32.7, 32.6, 32.5, 31.9, 28.4, 27.3, 26.6, 24.1, 23.9, 23.1, 22.9 (see following table for not observed signals); IR (thin film): 3005, 2953, 2924, 2851, 2242, 1651, 1646, 1637, 1464, 1419, 1269, 1157, 993, $912 \mathrm{~cm}^{-1}$; HRMS calc'd for $\mathrm{C}_{28} \mathrm{H}_{36} \mathrm{~N}_{2} \mathrm{O}_{3}=448.2726$, found = 448.2728. Compound 51 is spectroscopically identical to that reported by Nishida (J. Am. Chem. Soc. 2003, 125, 7484 and Angew. Chem. Int. Ed. 2004, 43, 2020).

Comparison of observed ${ }^{13} \mathrm{C}$-NMR signals with those reported by Nishida (Angew. Chem. Int. Ed. 2004, 43, 2020)

\begin{tabular}{|c|c|}
\hline Nishida & $\begin{array}{c}\text { Kerr } \\
\text { (Observed) }\end{array}$ \\
\hline 173.7 & 173.6 \\
173.4 & \\
172.9 & 172.8 \\
172.1 & \\
161.9 & 161.9 \\
161.8 & \\
155.3 & 155.4 \\
154.6 & 154.6 \\
138.2 & 138.2 \\
138.1 & \\
137.54 & 137.54 \\
137.49 & 137.49 \\
134.4 & 134.4 \\
133.5 & 133.5 \\
128.6 & \\
128.0 & 128.0 \\
127.9 & 127.9 \\
127.6 & 127.5 \\
\hline
\end{tabular}

\begin{tabular}{|c|c|}
\hline Nishida & $\begin{array}{c}\text { Kerr } \\
\text { (Observed) }\end{array}$ \\
\hline 115.20 & \\
115.19 & 115.16 \\
115.17 & 115.1 \\
115.1 & 102.5 \\
102.5 & 102.4 \\
102.4 & \\
63.61 & 63.57 \\
63.57 & 59.7 \\
$59.7(2 C)$ & 57.6 \\
57.6 & 57.4 \\
57.4 & \\
48.0 & 43.9 \\
43.9 & 43.5 \\
43.5 & 43.1 \\
43.1 & 41.1 \\
41.1 & \\
40.6 & 40.1 \\
40.1 & \\
\hline
\end{tabular}

\begin{tabular}{|c|c|}
\hline Nishida & $\begin{array}{c}\text { Kerr } \\
\text { (Observed) }\end{array}$ \\
\hline 39.8 & \\
33.4 & 33.4 \\
33.3 & 33.3 \\
32.9 & 32.9 \\
32.7 & 32.7 \\
32.6 & 32.6 \\
32.5 & 32.5 \\
$31.9(2 C)$ & 31.9 \\
$28.4(2 C)$ & 28.4 \\
27.3 & 27.3 \\
26.9 & \\
26.7 & \\
26.6 & 26.6 \\
24.1 & 24.1 \\
23.9 & 23.9 \\
23.1 & 23.1 \\
22.9 & 22.9 \\
\hline
\end{tabular}




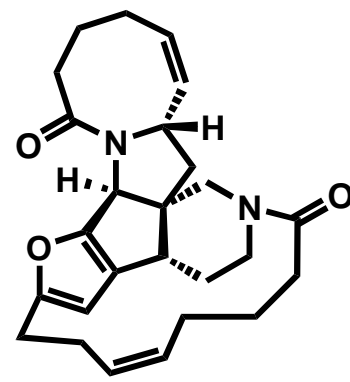

Compound $52-Z$

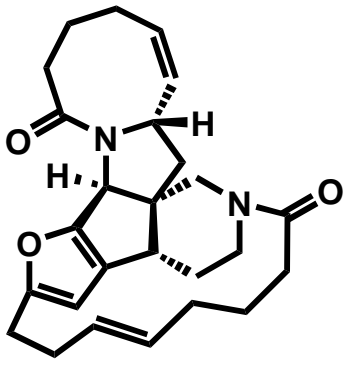

Compound 52-E

The mixture of $\mathbf{5 1}$ and triphenylphosphine oxide (23 mg) was dissolved in $\mathrm{CH}_{2} \mathrm{Cl}_{2}(70 \mathrm{~mL})$ and to this solution was added Grubbs First Generation Catalyst (3.6 mg, $0.0044 \mathrm{mmol}$, 30 mol\%). The reaction flask was evacuated and back filled with argon five times, and then refluxed for 23 hours. The solvent was removed under reduced pressure, and a crude NMR indicated that the reaction had gone to completion and that the ratio of mixture was then purified by column chromatography on silica gel, (hexanes / ethyl acetate as eluent) to yield the undesired $\mathbf{5 2 - E}(6.2 \mathrm{mg})$ and $\mathbf{5 2 - Z}(4.0 \mathrm{mg})$. Due to the small scale and similarity in $\mathrm{R}_{\mathrm{f}}$, a

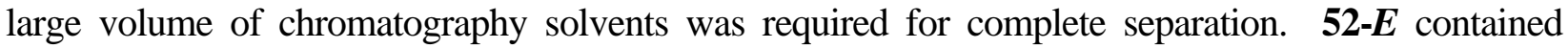
substantial solvent derived impurities so it was resubjected to chromatography to yield $\mathbf{5 2 - \boldsymbol { E }}$ (3.2 $\mathrm{mg}$, $0.0077 \mathrm{mmol}$, 28\% over 2 steps). Compound $52-Z$ had a lesser degree of chromatography solvent derived impurities, so it was used directly in the next step, and the yield will be given over a three step sequence. A visual comparison of the proton spectra to Nishida's is included for $\mathbf{5 2 - E}$ and crude $\mathbf{5 2 - Z}$ in the spectral section.

Compound 52- $E$ (undesired isomer) $-\mathrm{R}_{\mathrm{f}}=0.28,100 \%$ ethyl acetate; ${ }^{1} \mathrm{H}-\mathrm{NMR}\left(600 \mathrm{MHz}, \mathrm{CDCl}_{3}\right): \delta$ $=5.81(\mathrm{~s}, 1 \mathrm{H}), 5.60(\mathrm{dd}, \mathrm{J}=2.7,12.3 \mathrm{~Hz}, 1 \mathrm{H}), 5.56-5.51(\mathrm{~m}, 1 \mathrm{H}), 5.30-5.19(\mathrm{~m}, 2 \mathrm{H}), 4.99(\mathrm{~s}, 1 \mathrm{H})$, 4.60 (d, J = 13.8 Hz, 1H), 4.48-4.45 (m, 1H), 3.36-3.30 (m, 1H), 3.23 (dd, J = 11.4, 6.6 Hz, 1H), 3.04 (s, 1H), 2.88-2.84 (m, 2H), 2.65-2.57 (m, 3H), 2.42-2.36 (m, 1H), 2.24-2.17 (m, 5H), 2.07-2.01 (m, 3H), 1.97-1.80 (m, 5H), 1.74-1.60 (m, 4H), 1.52-1.41 (m, 3H), 0.96-0.80 (m, 4H). Accurate integration of the protons from 1.7-0.8 ppm was difficult due to grease contamination; HRMS calc'd for $\mathrm{C}_{26} \mathrm{H}_{32} \mathrm{~N}_{2} \mathrm{O}_{3}=420.2413$, found $=420.2422$

Compound $52-Z-R_{f}=0.13,100 \%$ ethyl acetate; $\mathbf{5 2 - Z}$ contained chromatography solvent impurities and was used directly in the next step.

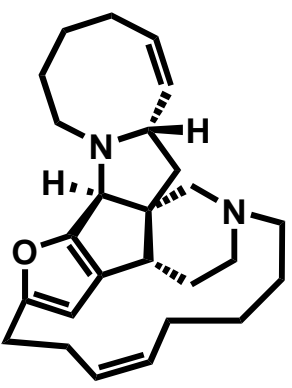

(+)-ent-Nakadomarin A

(+)-Nakadomarin $\mathbf{A}$ is prepared from $52-Z$ using the procedure of Nishida (Angew. Chem. Int. Ed. 2004, 43, 2020). A solution of the bis-amide 52-Z (4.0 mg with impurities) in toluene $(4 \mathrm{~mL})$ was cooled to $0{ }^{\circ} \mathrm{C}$. Red-Al (80 $\mu \mathrm{L}$ of a $65 \%$ solution in toluene) was added and stirring continued for 10 minutes at this temperature. The reaction was then heated to reflux for 3 hours, then quenched at $-30{ }^{\circ} \mathrm{C}$ with saturated aqueous Rochelle's salt (3 $\mathrm{mL}$ ). After warming to room temperature, the mixture was stirred vigorously for 1 hour, then ethyl acetate ( $3 \mathrm{~mL}$ ) was added, and vigorous stirring continued for an additional hour. The layers were separated, and the aqueous layer extracted 4 times with ethyl acetate. The combined organics were washed with saturated aqueous Rochelle's salt, twice with brine and the solvent removed under reduced pressure. The residue was purified by column chromatography on silica (methanol / ethyl acetate as eluent) to yield (+)-ent-Nakadomarin A (2.1 mg, $0.00535 \mathrm{mmol}, 20 \%$ over 3 steps) as pale yellow film. The chemical shifts of the protons next to the amines showed some variance with respect to those reported by Nishida, and Nishida attributed this to trace acid in his initial publication, J. Am. 
Chem. Soc. 2003, 125, 7484. $\mathrm{MeOH}-d_{4}(1 \mathrm{~mL})$ filtered through basic alumina was added to the sample and then removed under reduced pressure (running this sample directly led to a large water peak). Fresh $\mathrm{MeOH}-d_{4}$ was added to yield a spectrum that was identical to that published by Nishida. A comparison of the proton spectra (both the initial and neutralized) to Nishida's is included in the spectral section.

(+)-Nakadomarin A - $\mathrm{R}_{\mathrm{f}}=0.18$, 75\% methanol in ethyl acetate; ${ }^{1} \mathrm{H}-\mathrm{NMR}\left(600 \mathrm{MHz}, \mathrm{MeOH}-d_{4}\right): \delta=$ 5.87 (s, $1 \mathrm{H}), 5.83-5.79(\mathrm{~m}, 1 \mathrm{H}), 5.50$ (dd, $\mathrm{J}=9.0,8.7 \mathrm{~Hz}, 1 \mathrm{H}), 5.46-5.42(\mathrm{~m}, 1 \mathrm{H}), 5.28-5.24(\mathrm{~m}, 1 \mathrm{H})$, 3.94 (s, 1H), 3.75-3.71 (m, 1H), 3.04 (d, J = 12.6 Hz, 1H), 3.04-3.00 (m, 1H), 2.84 (br. s, 1H), 2.822.75 (m, 1H), 2.71 (dd, J = 6.0, $12.0 \mathrm{~Hz}, 1 \mathrm{H}$ ), 2.64-2.59 (m, 2H), 2.51-2.46 (m, 1H), 2.40 (ddd, J = 3.6, 3.0, $11.4 \mathrm{~Hz}, 1 \mathrm{H}), 2.36-2.29$ (m, 2H), 2.30 (d, J = 12.6 Hz, 1H), 2.19-1.97 (m, 5H), 1.94-1.89 (m, 2H), 1.82 (ddd, $\mathrm{J}=3.0,7.2,14.0 \mathrm{~Hz}, 1 \mathrm{H}), 1.74-1.59$ (m, 4H), 1.49 (dd, J = 9.9, $12.3 \mathrm{~Hz}, 1 \mathrm{H}), 1.42-1.23$ (m, $2 \mathrm{H}), 1.09-1.04(\mathrm{~m}, 1 \mathrm{H}), 0.91-0.84(\mathrm{~m}, 2 \mathrm{H})$. Accurate integration of the protons from 1.7-0.8 ppm was difficult due to grease contamination; IR (thin film): 3006, 2926, 2857, 2793, 1457, 1132, 1081, 954 $\mathrm{cm}^{-1}$; HRMS calc'd for $\mathrm{C}_{26} \mathrm{H}_{36} \mathrm{~N}_{2} \mathrm{O}=392.2828$, found $=392.2815 ;[\alpha]_{\mathrm{D}}=+60.7(c=0.27, \mathrm{MeOH})$, literature $[\alpha]_{\mathrm{D}}=-73.0(c=0.08, \mathrm{MeOH})($ Angew. Chem. Int. Ed. 2004, 43, 2020). 


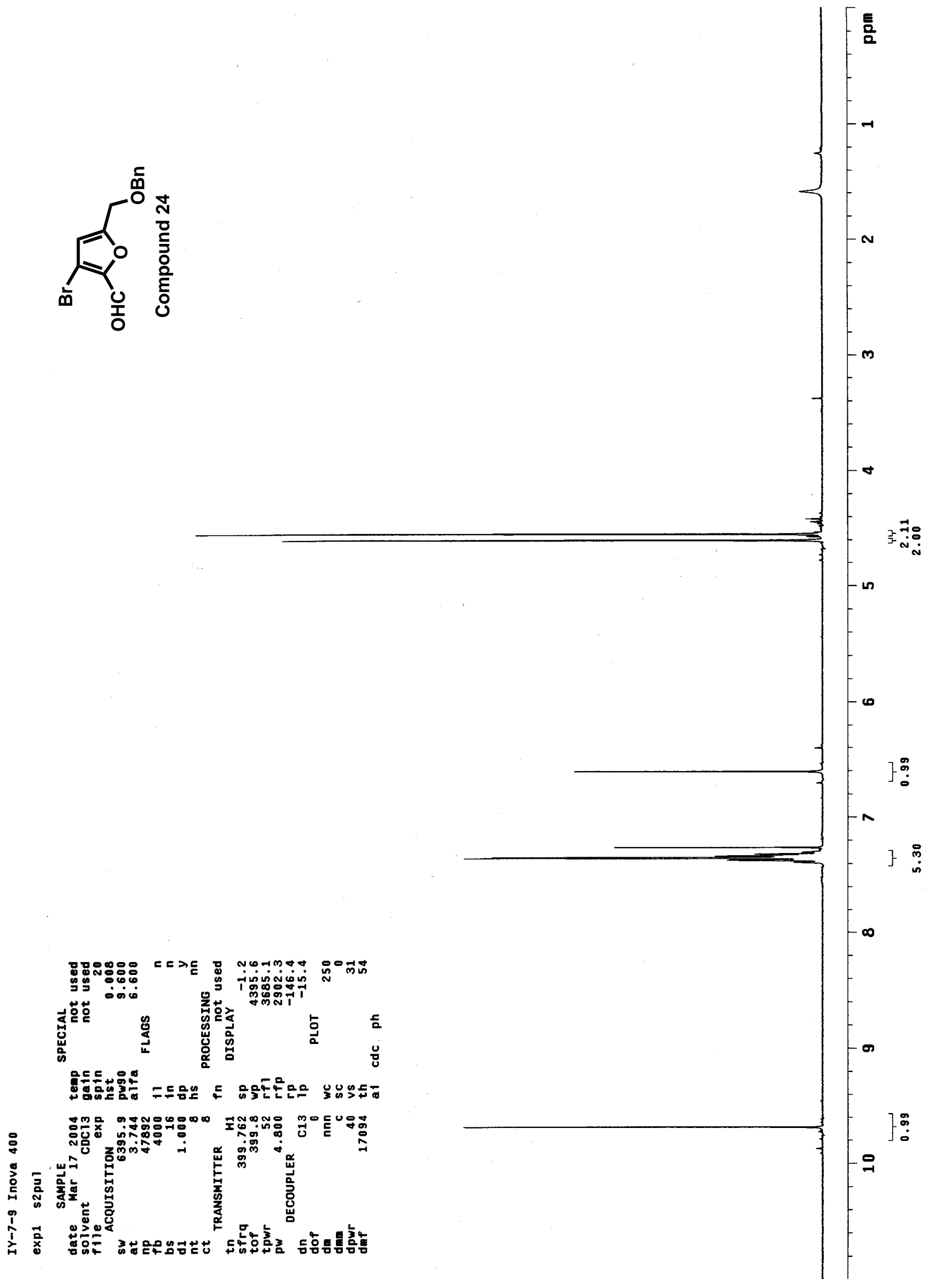



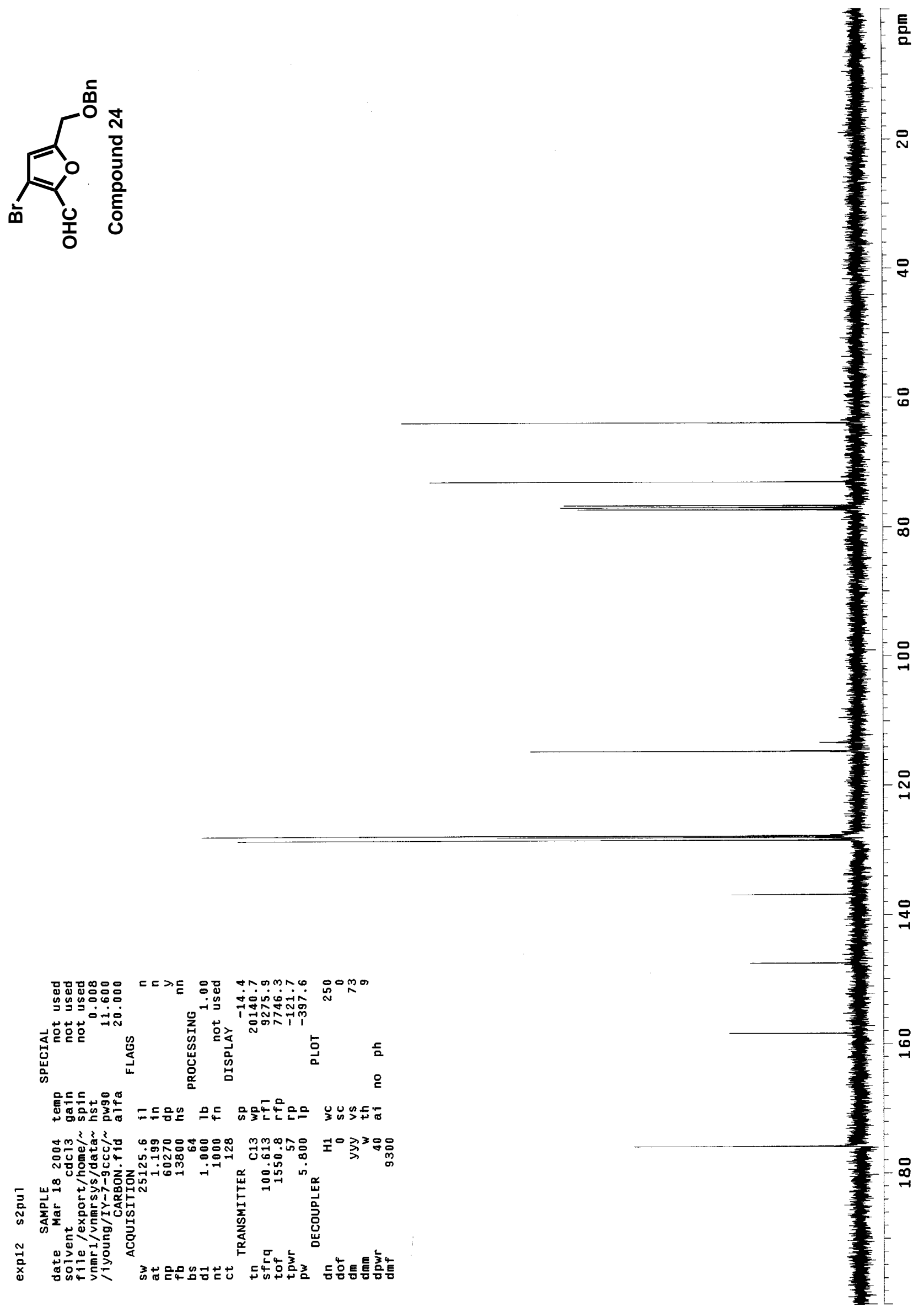


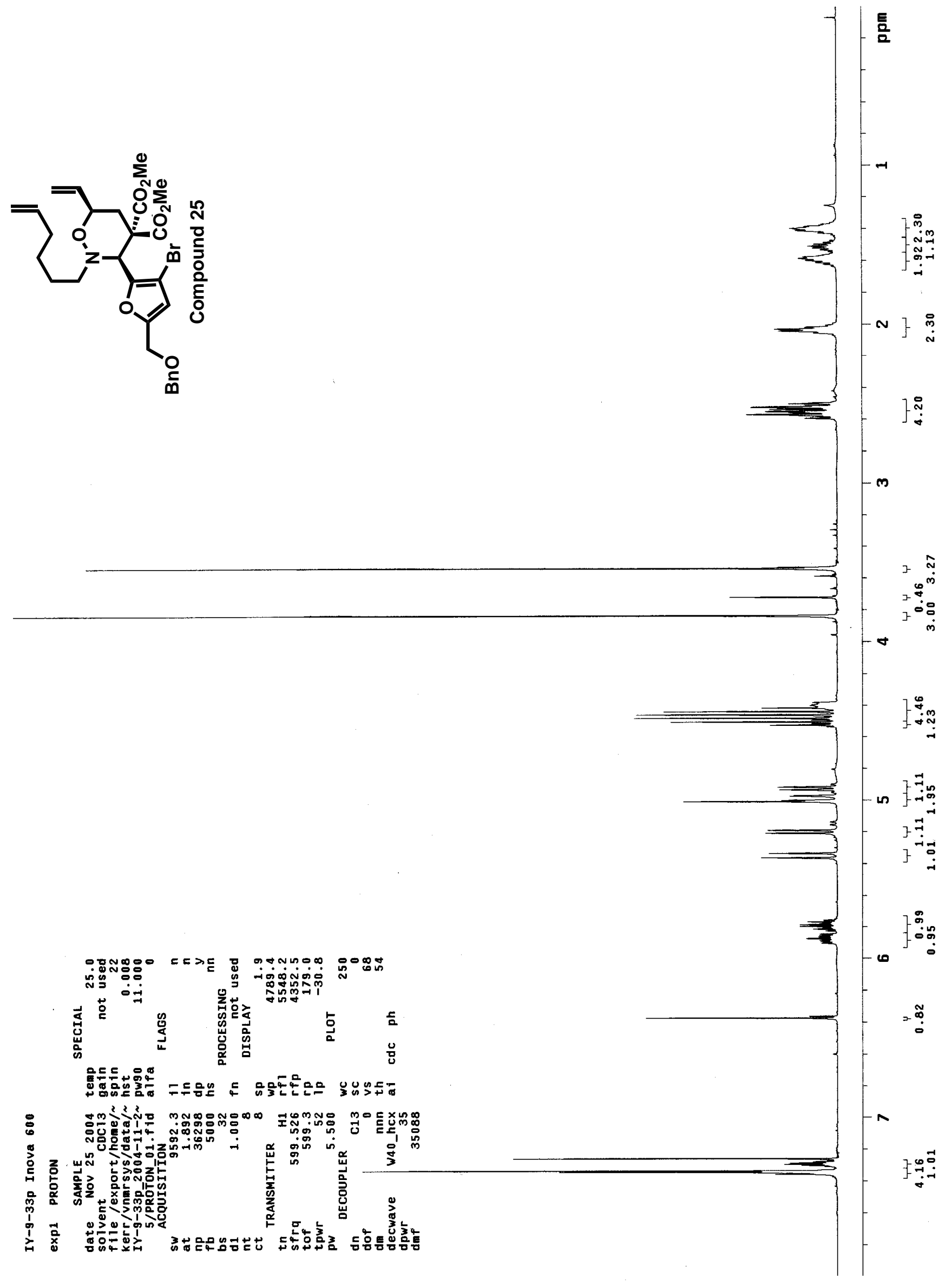




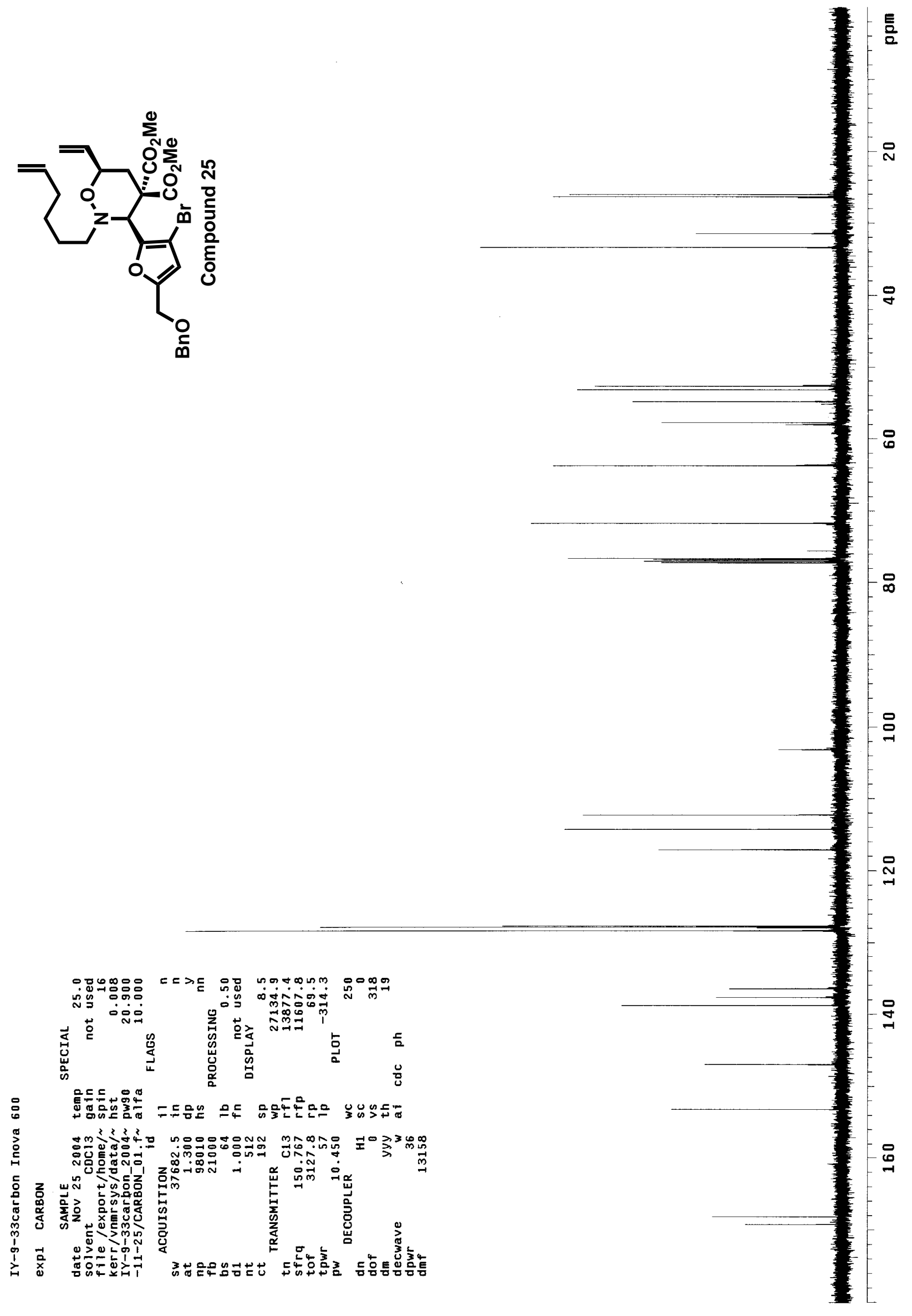




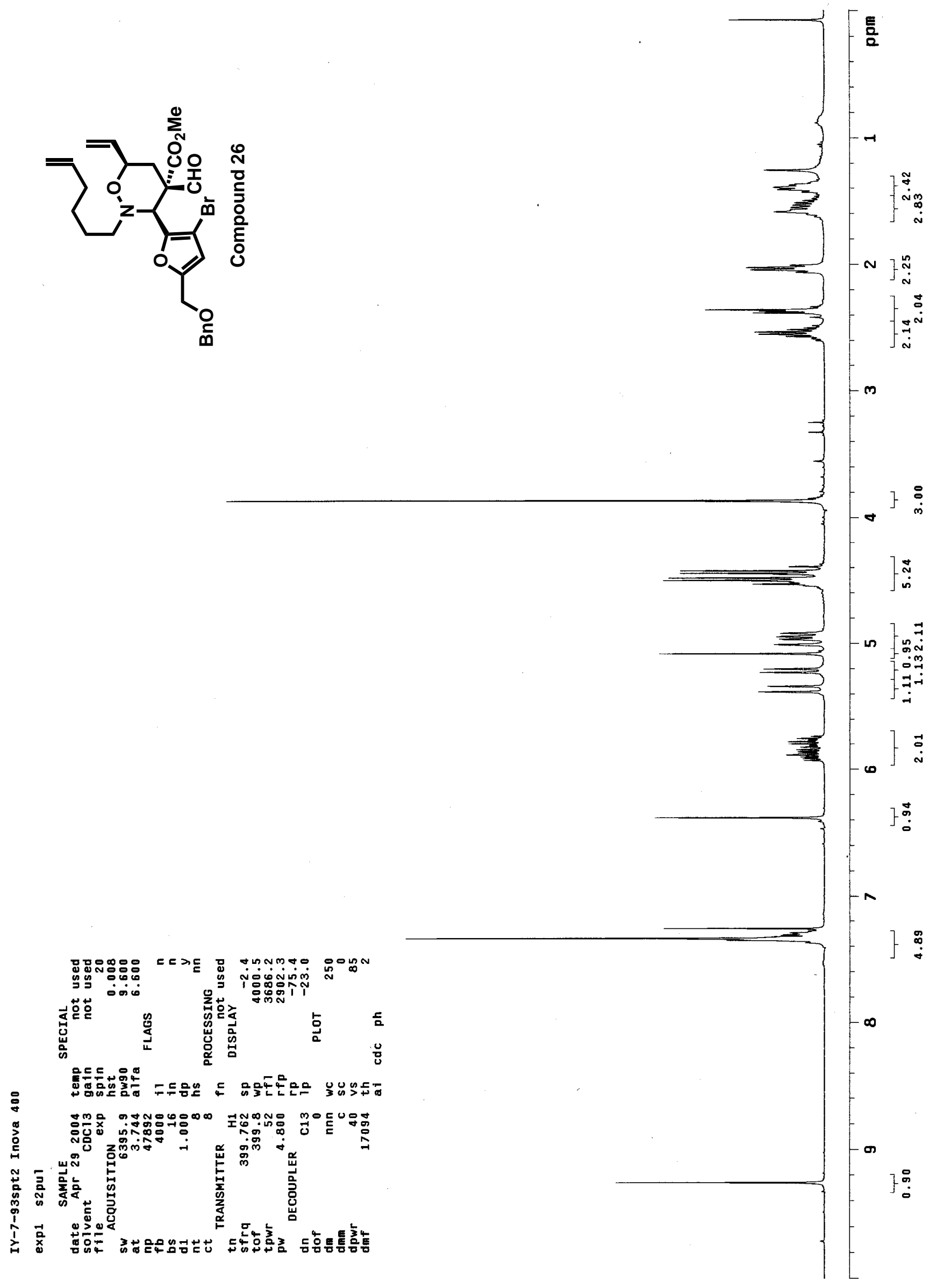



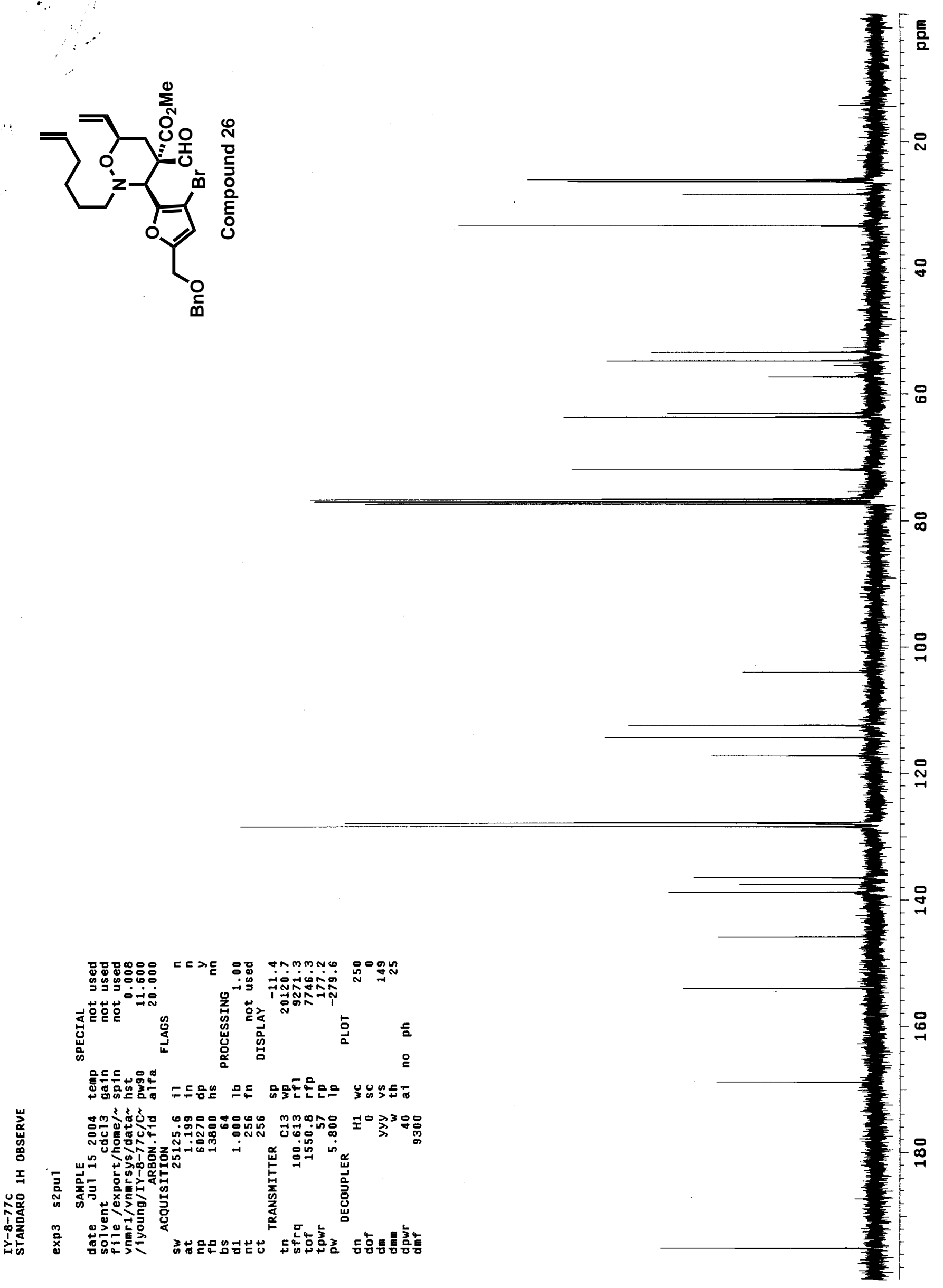


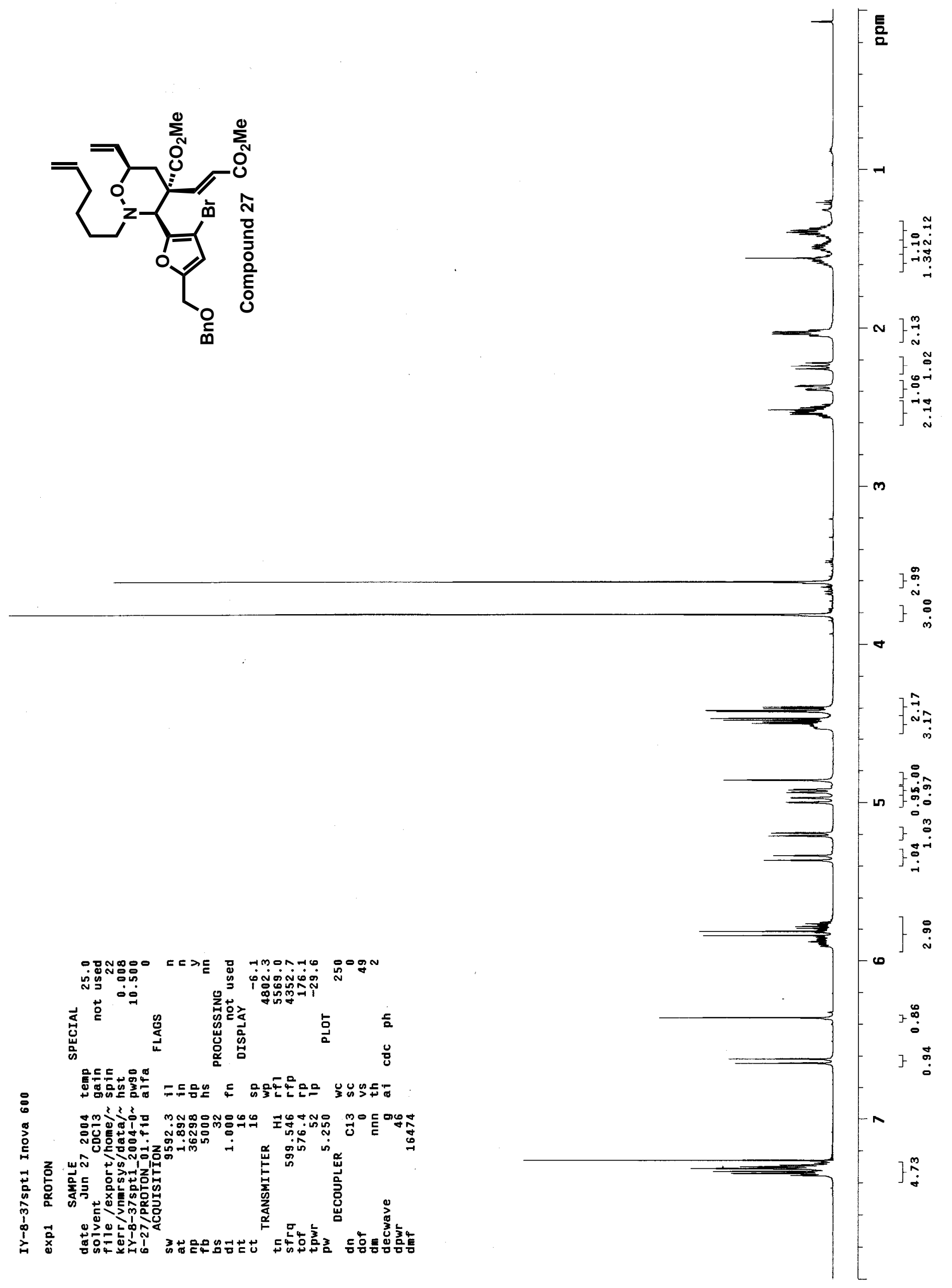




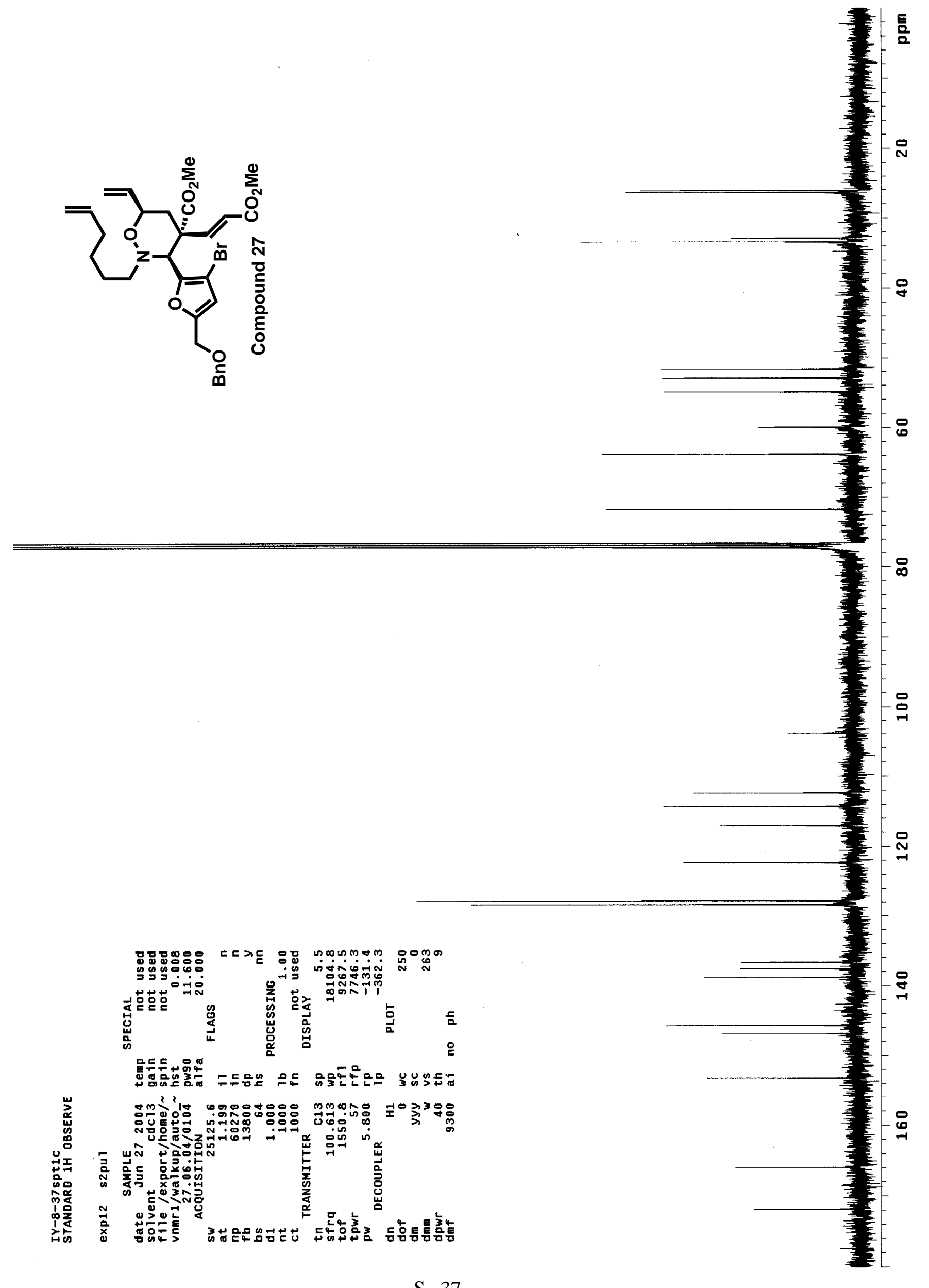




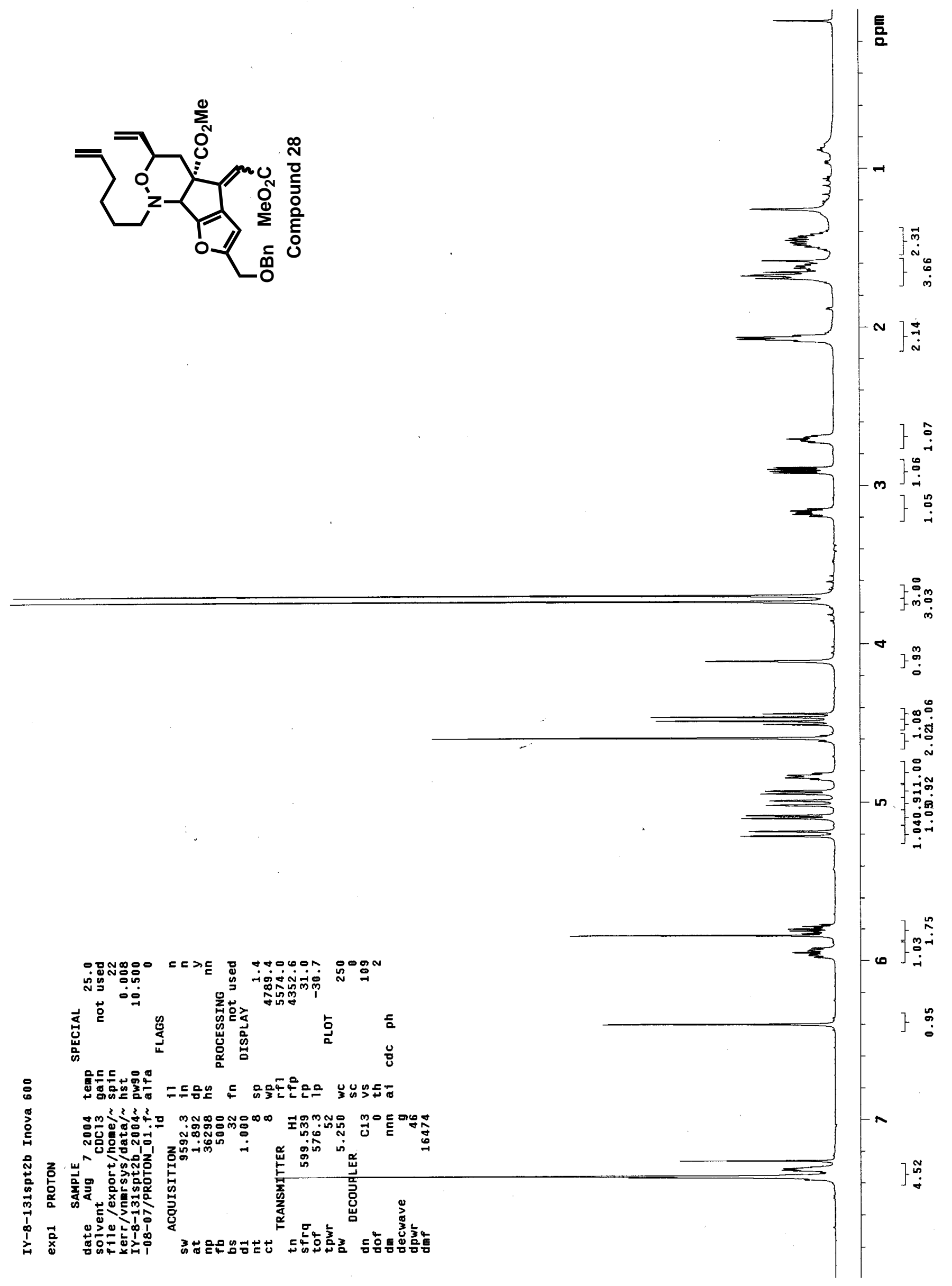



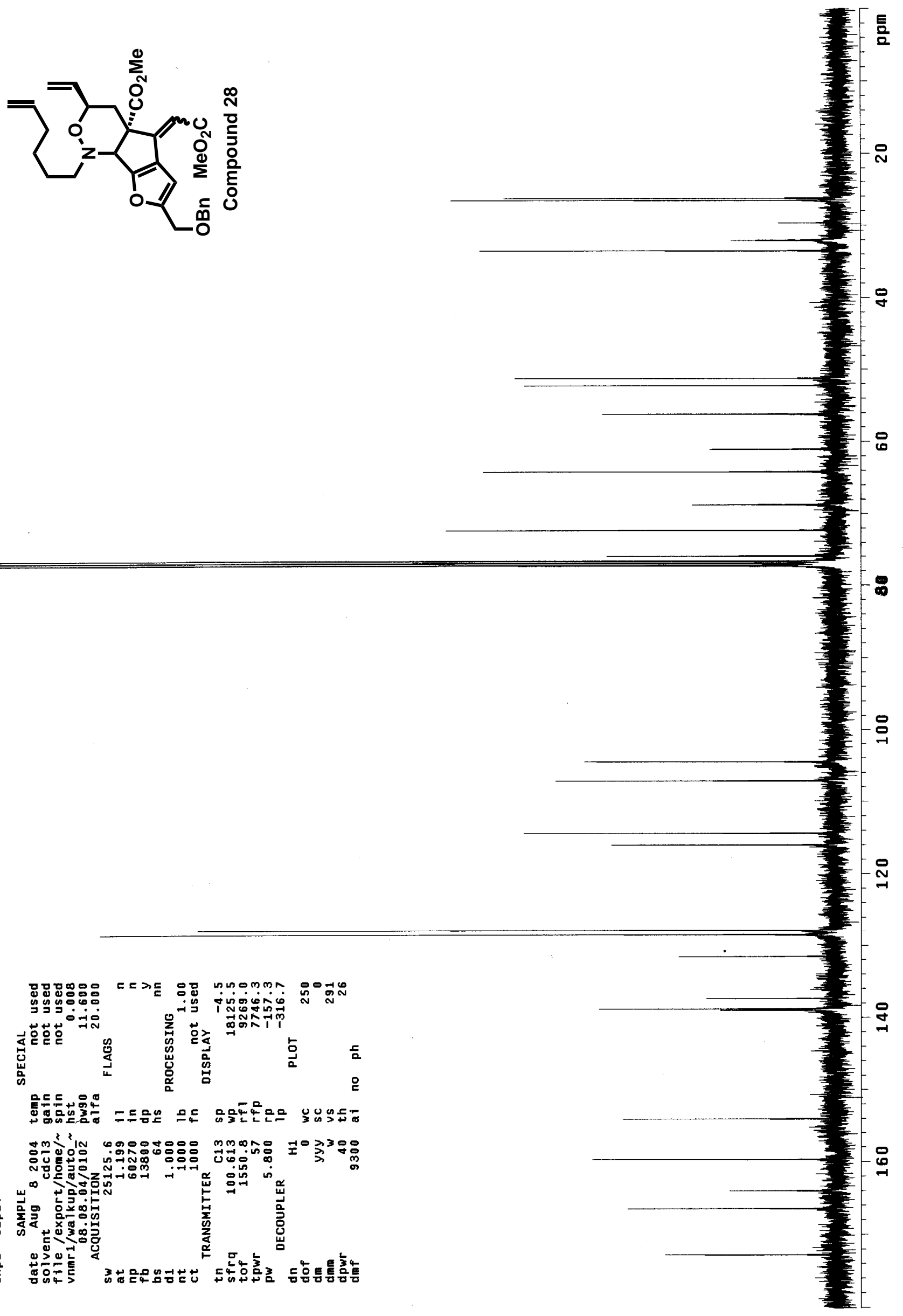

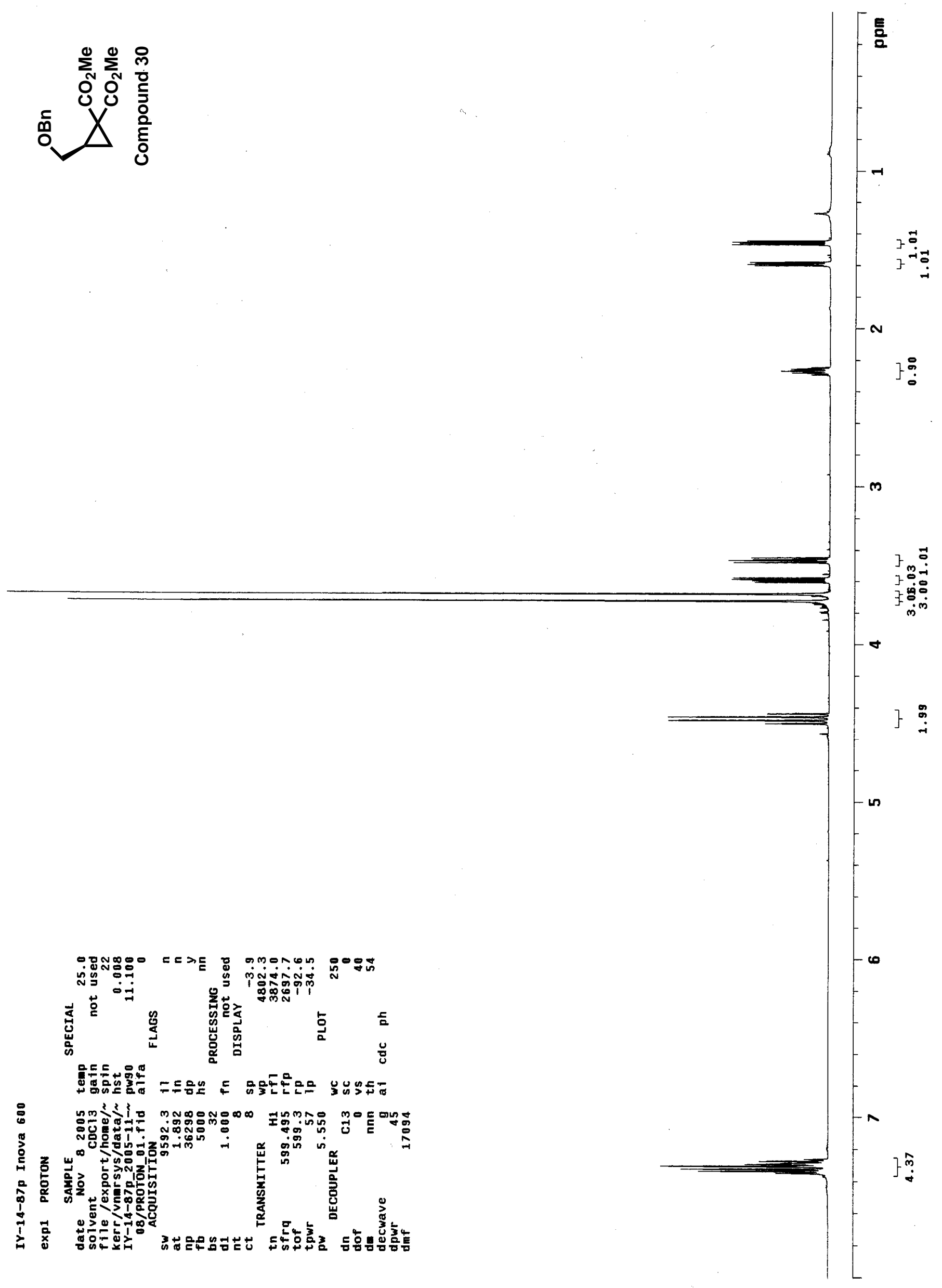

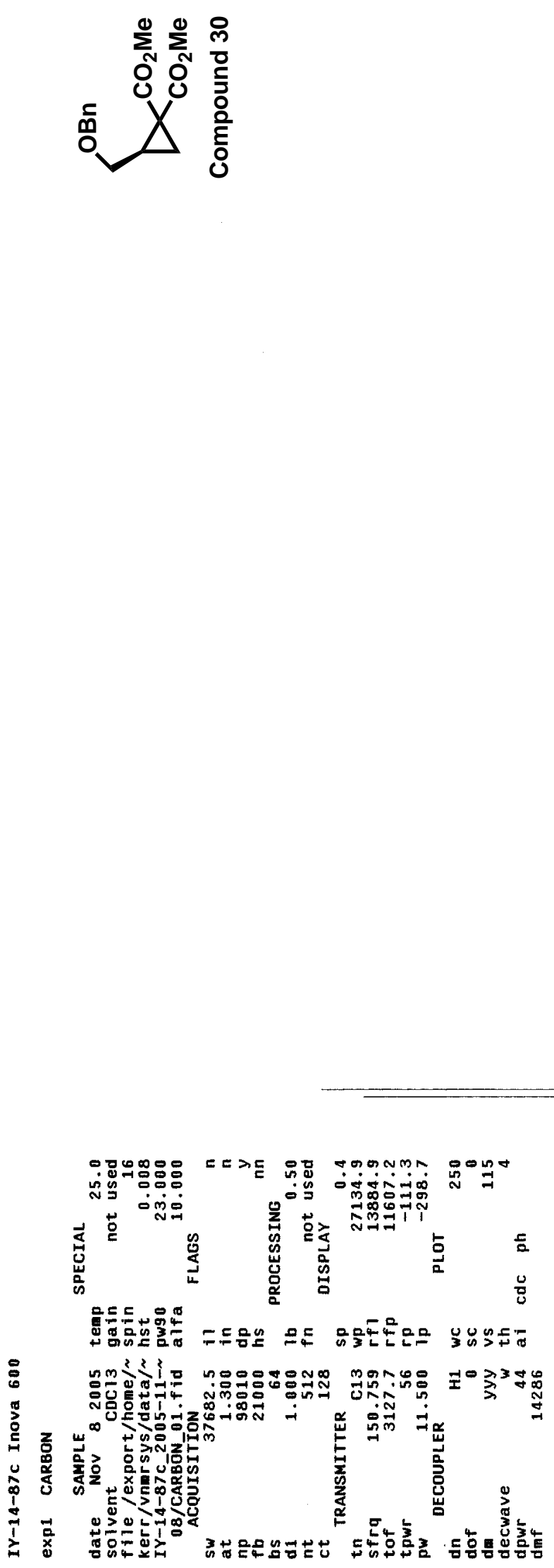

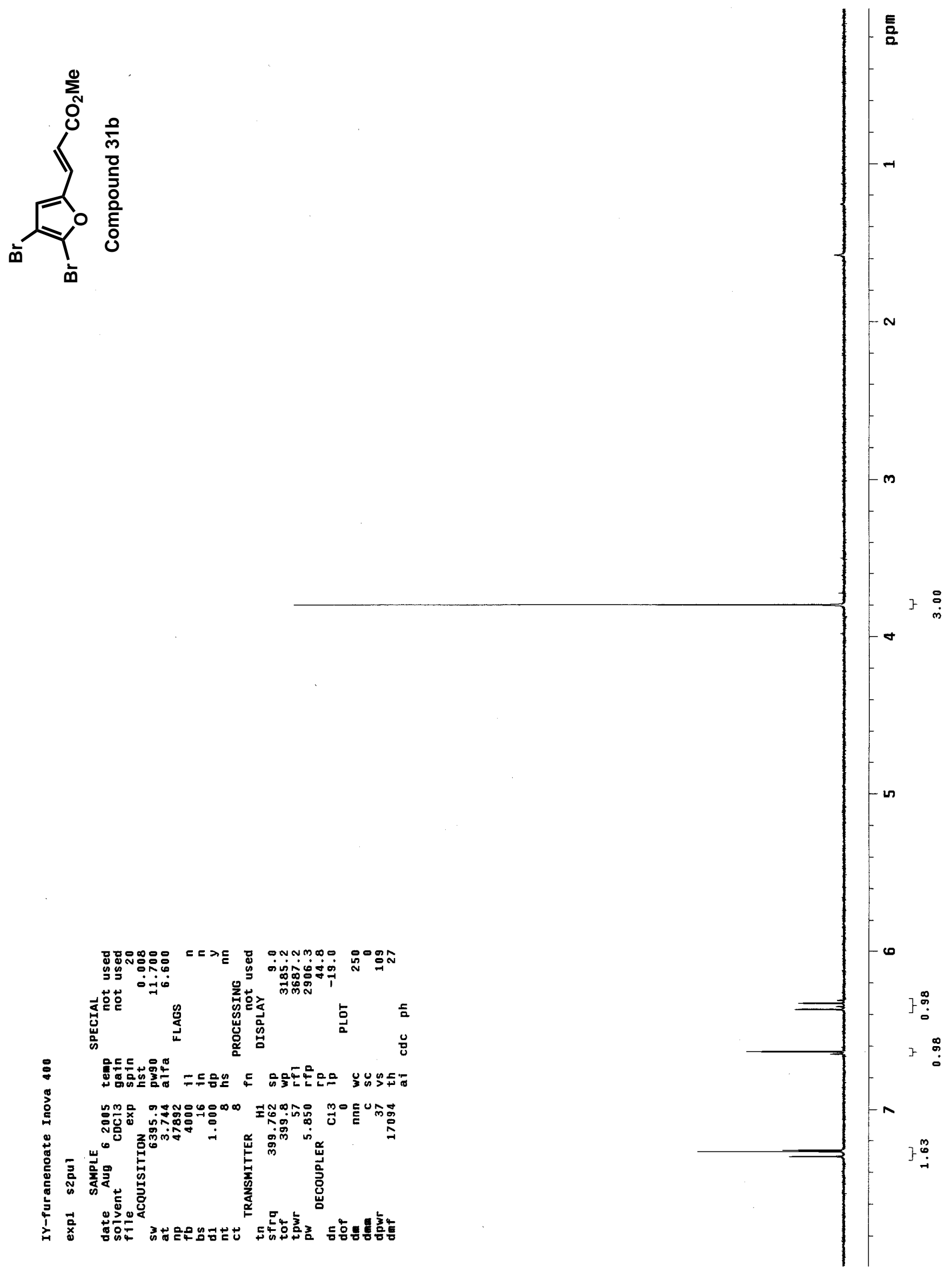

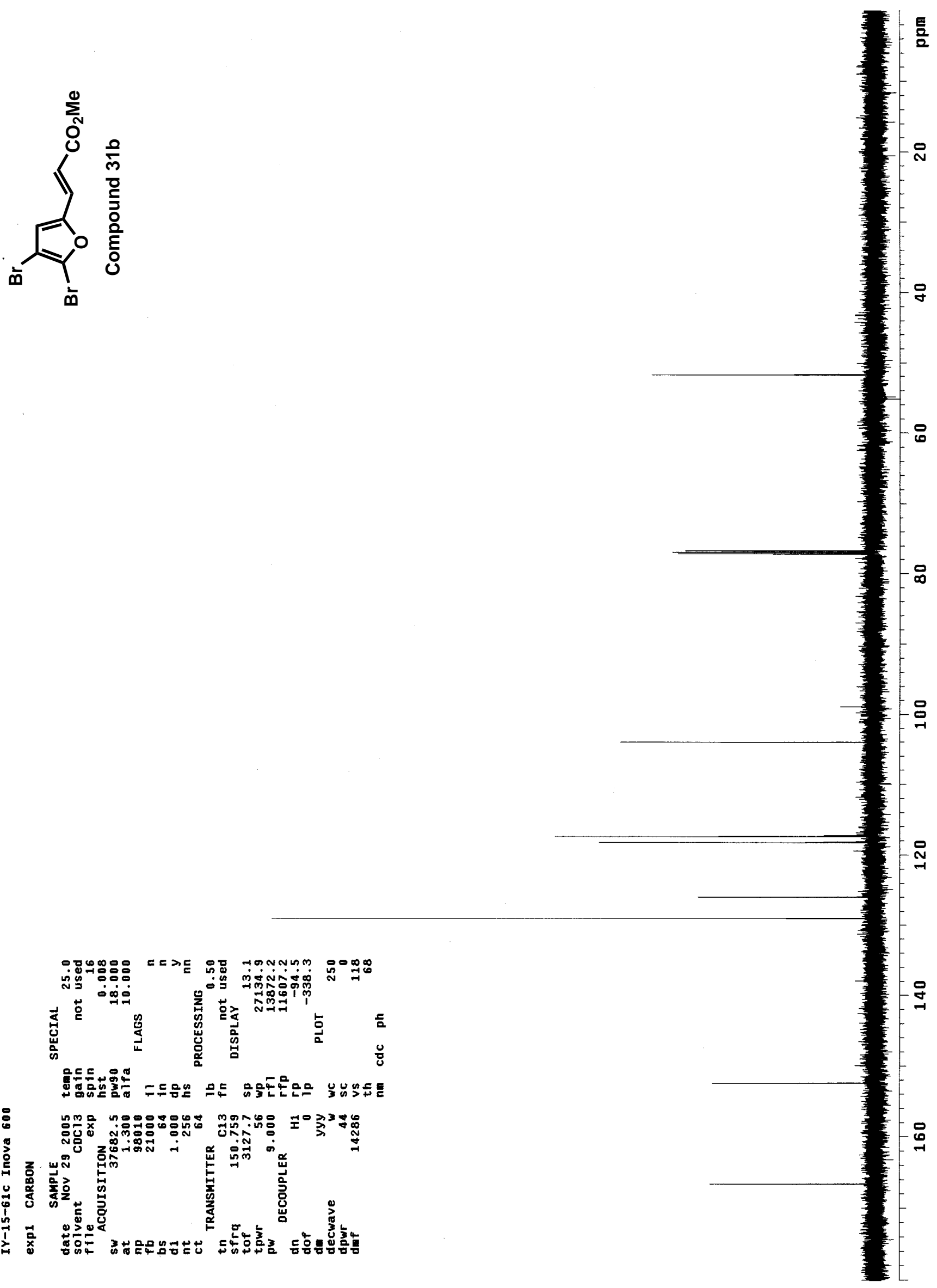

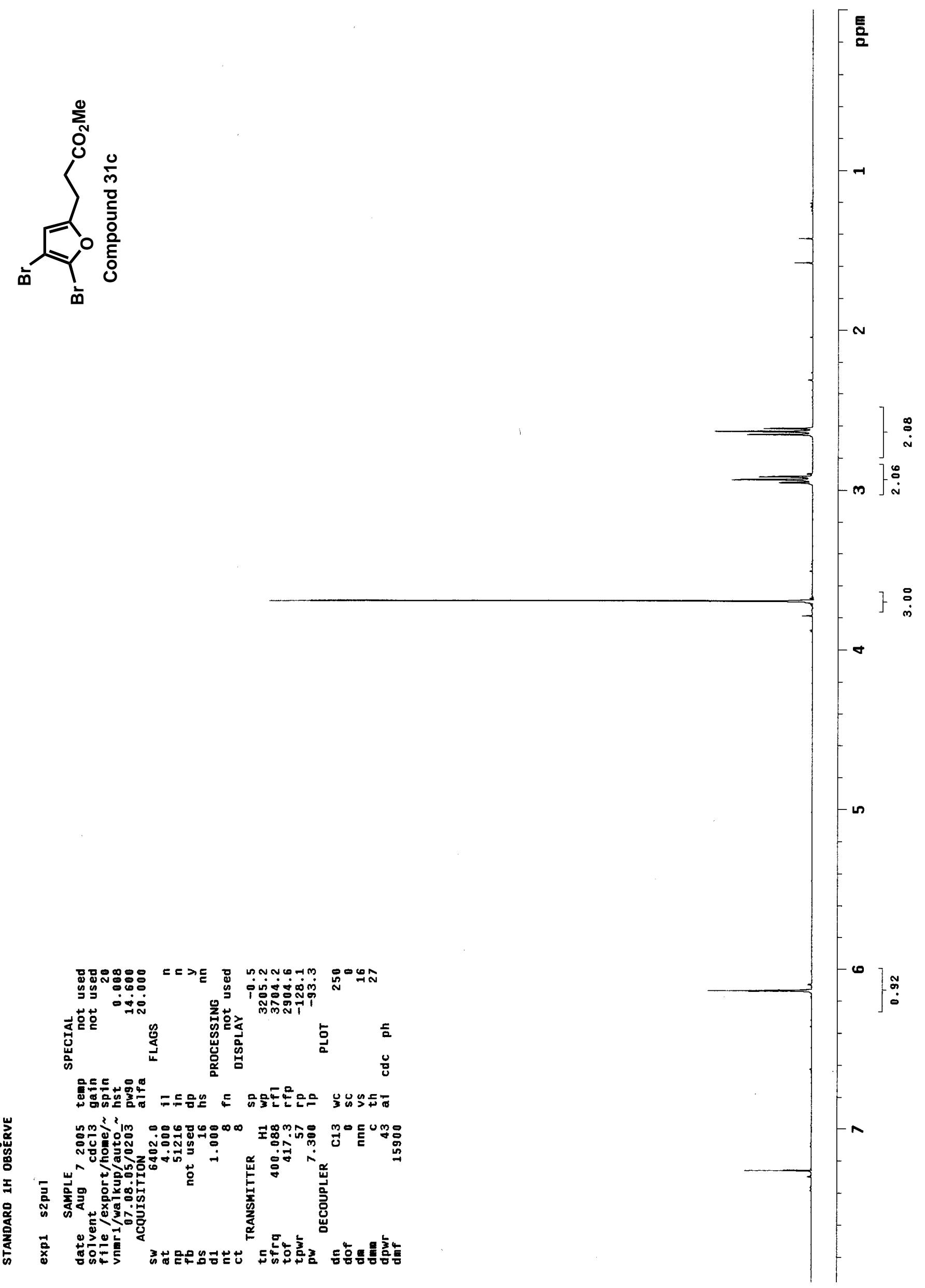

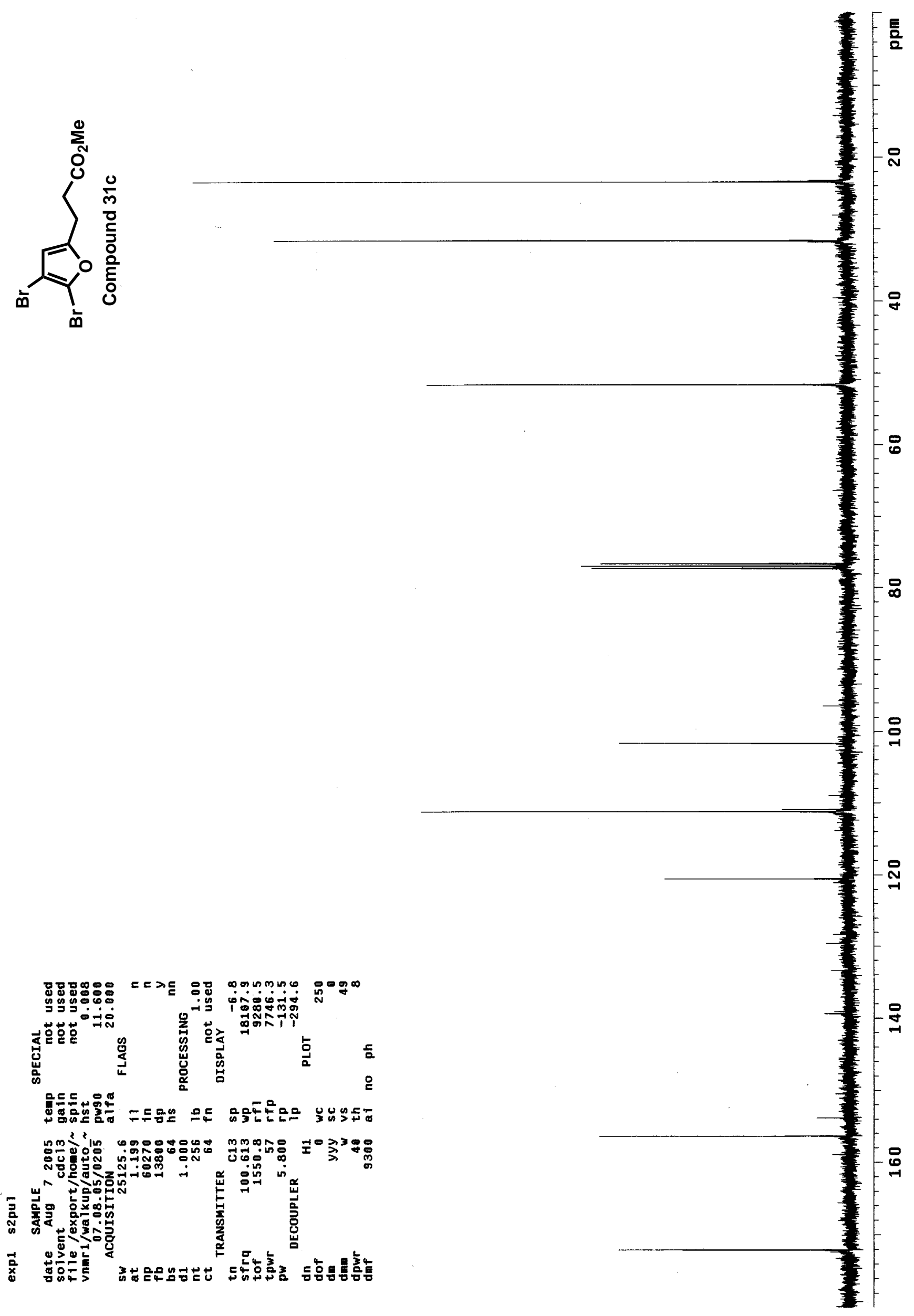


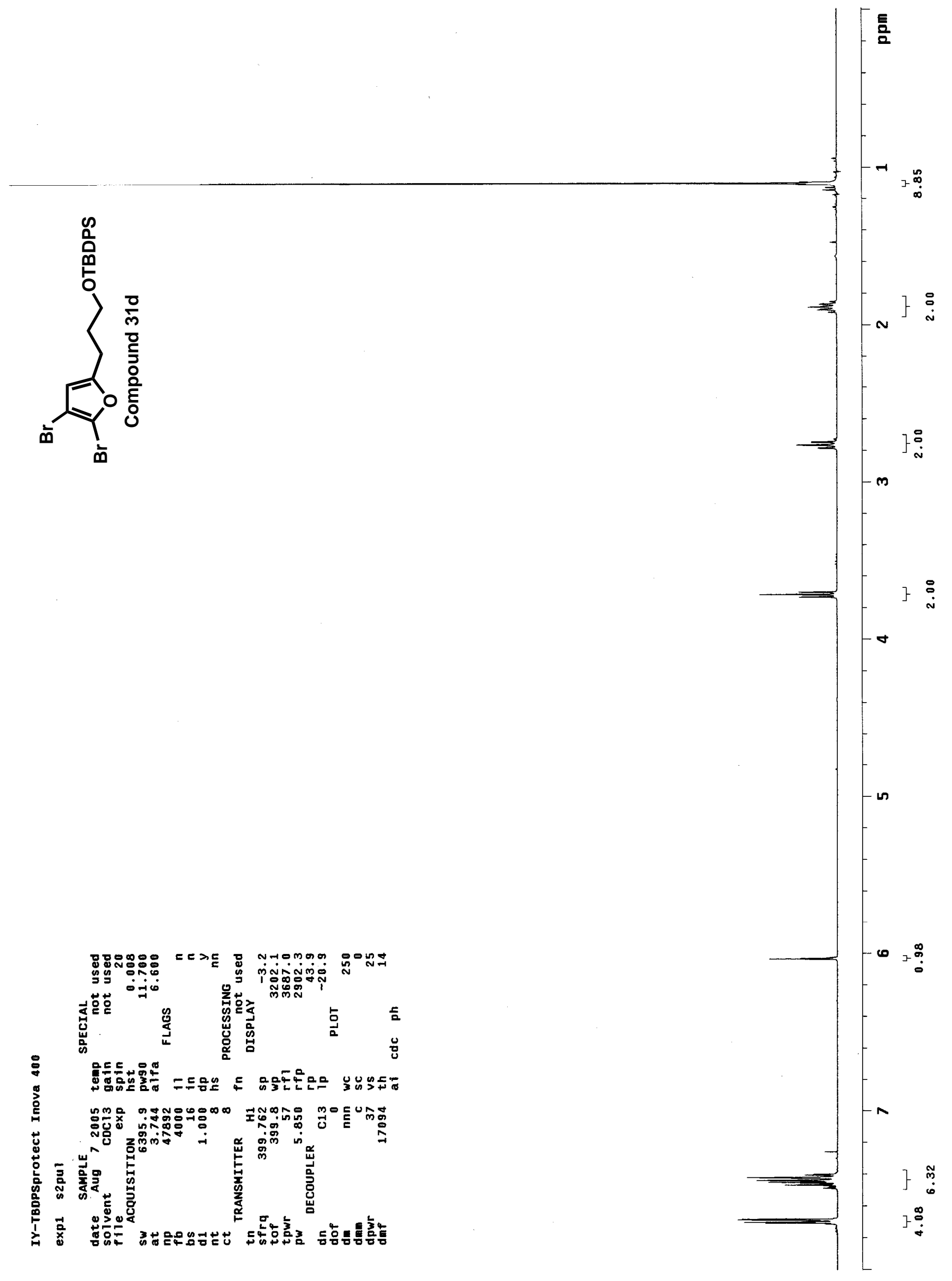




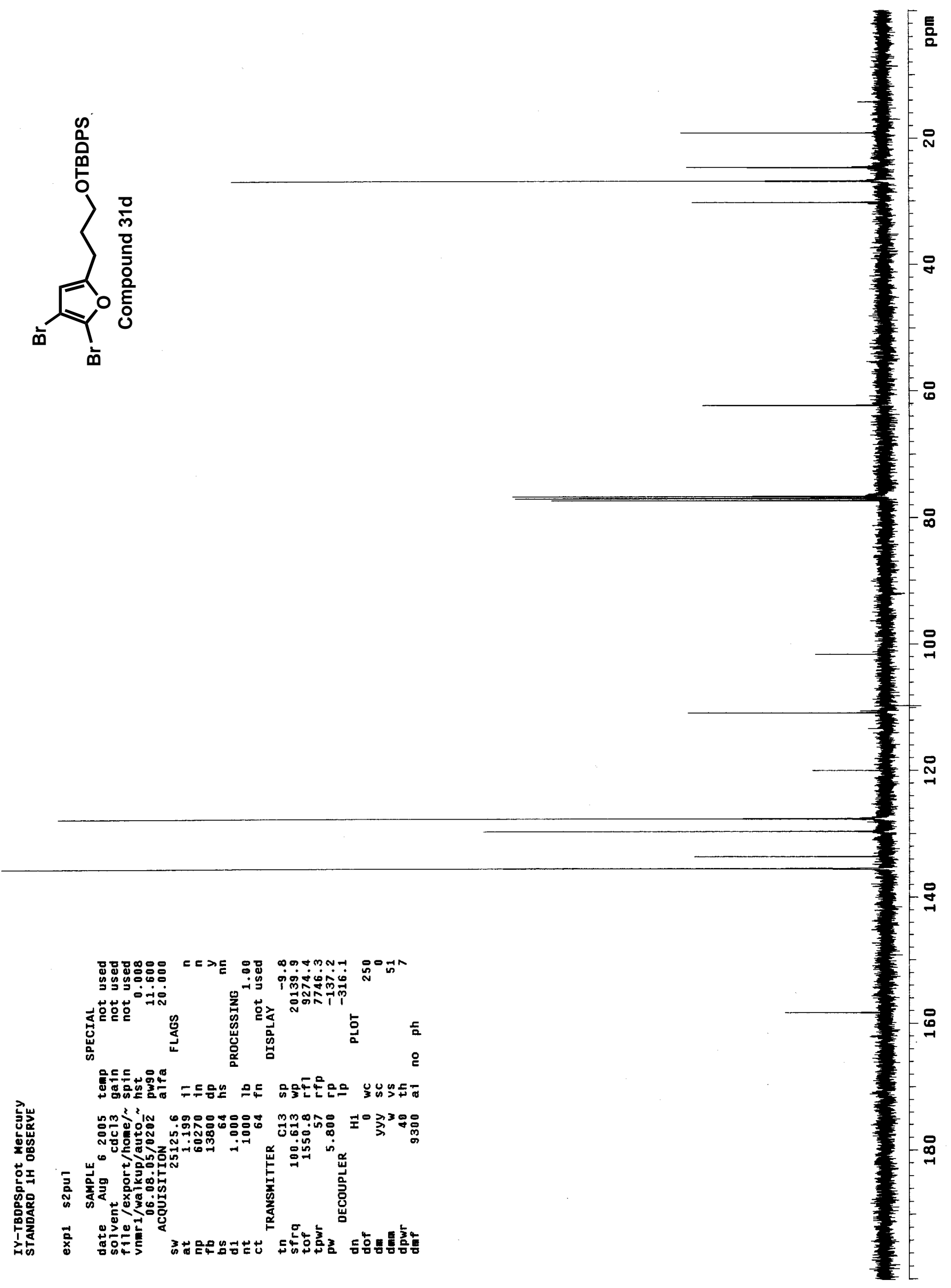




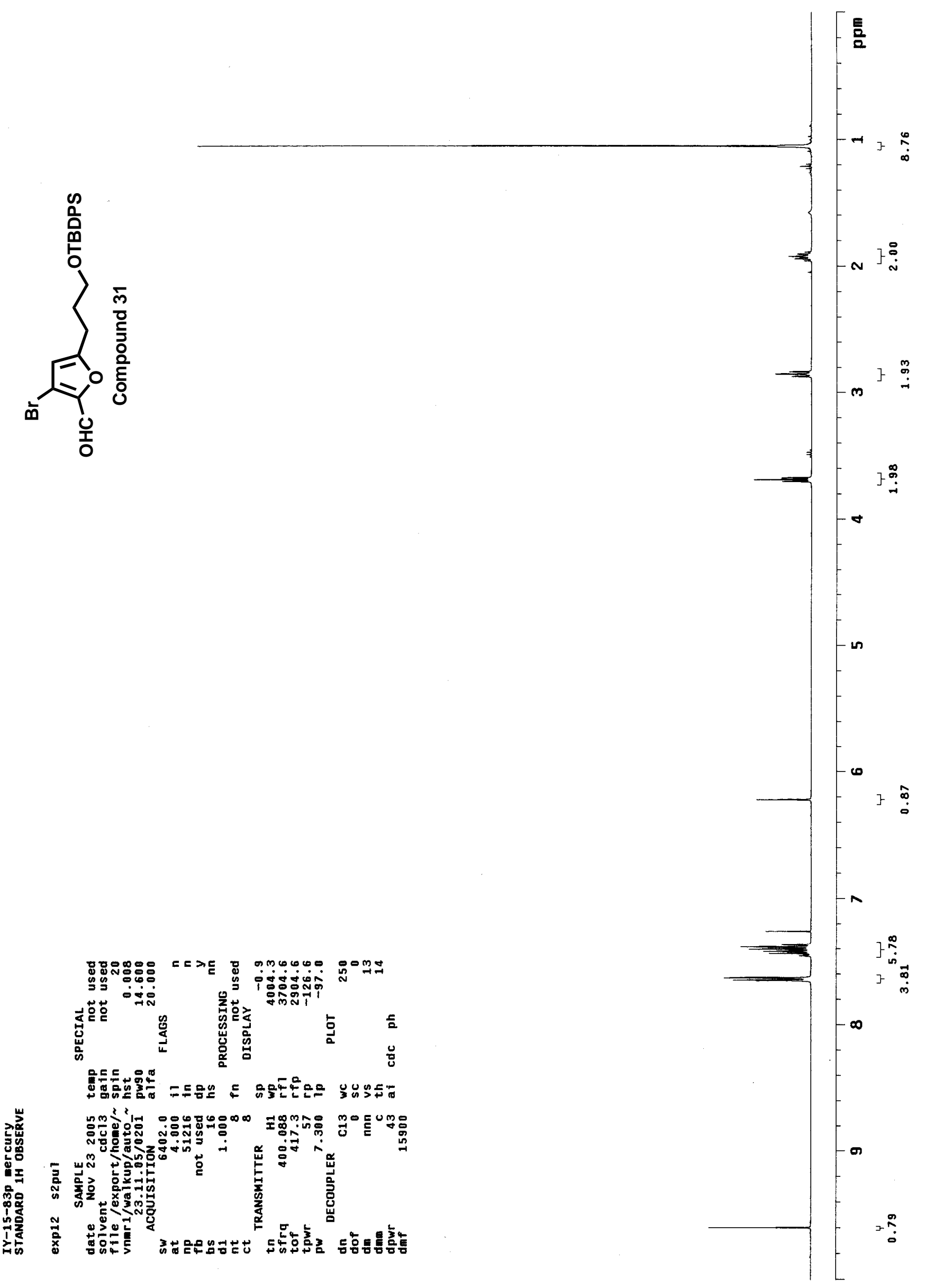




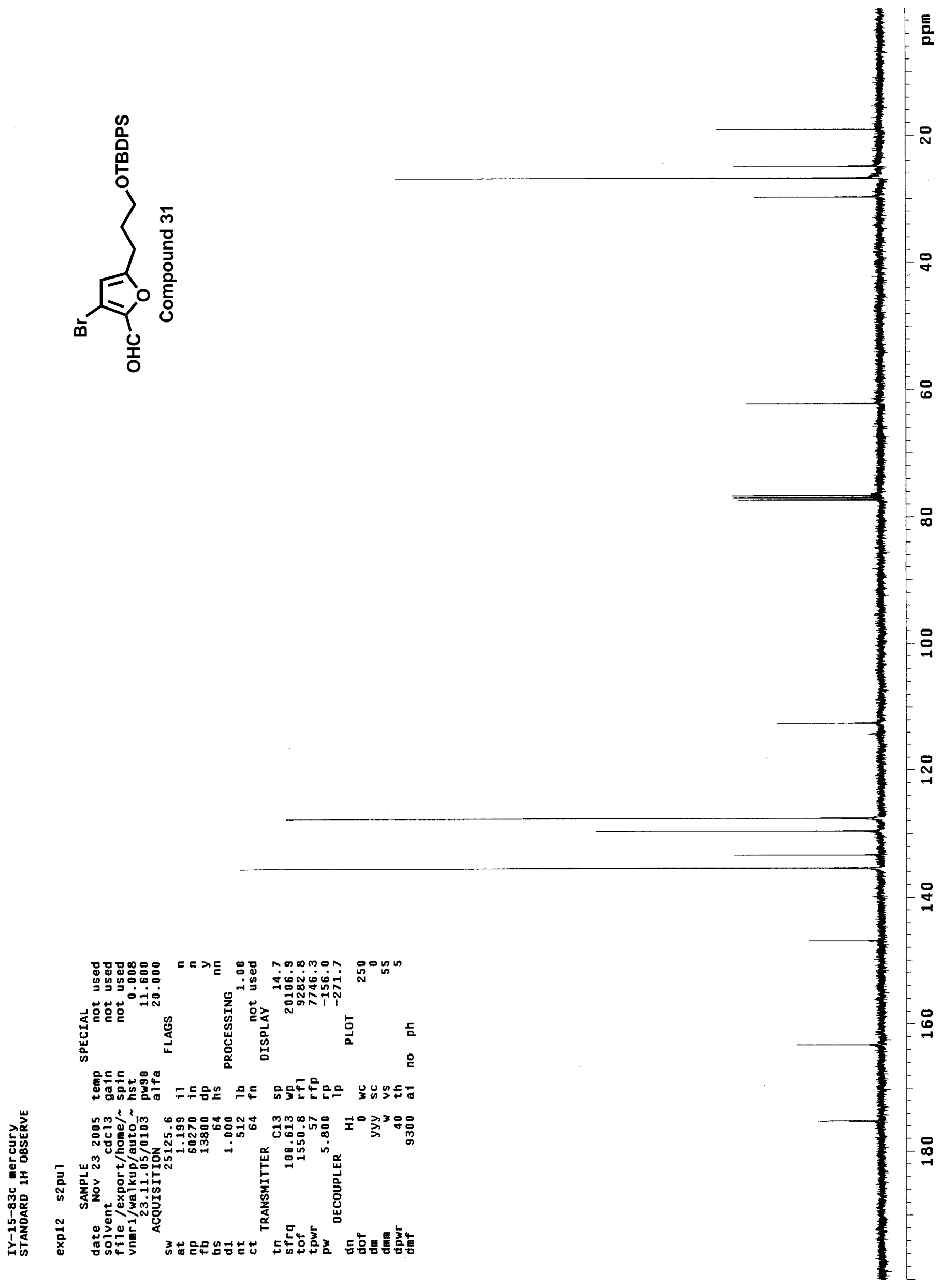




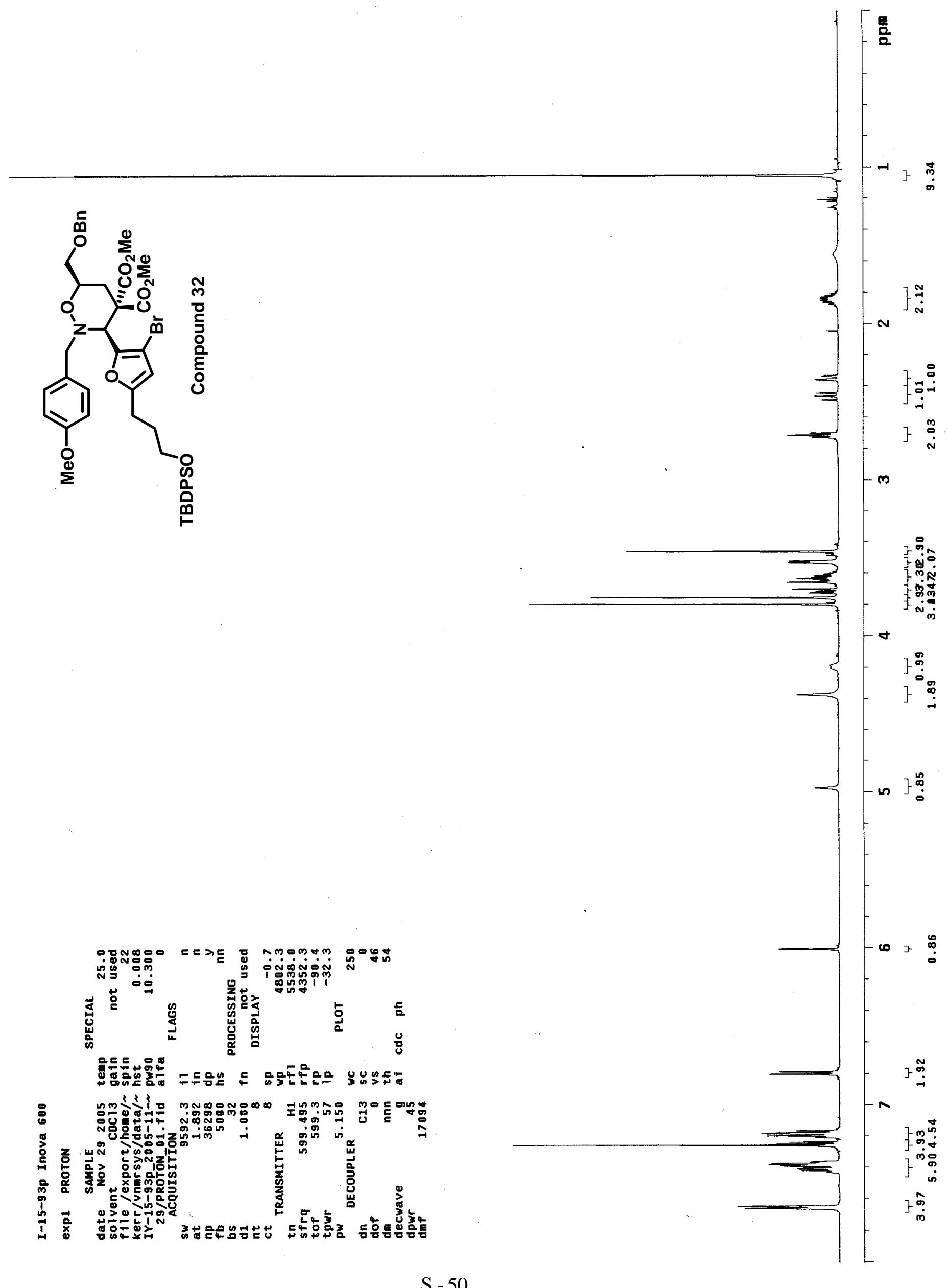



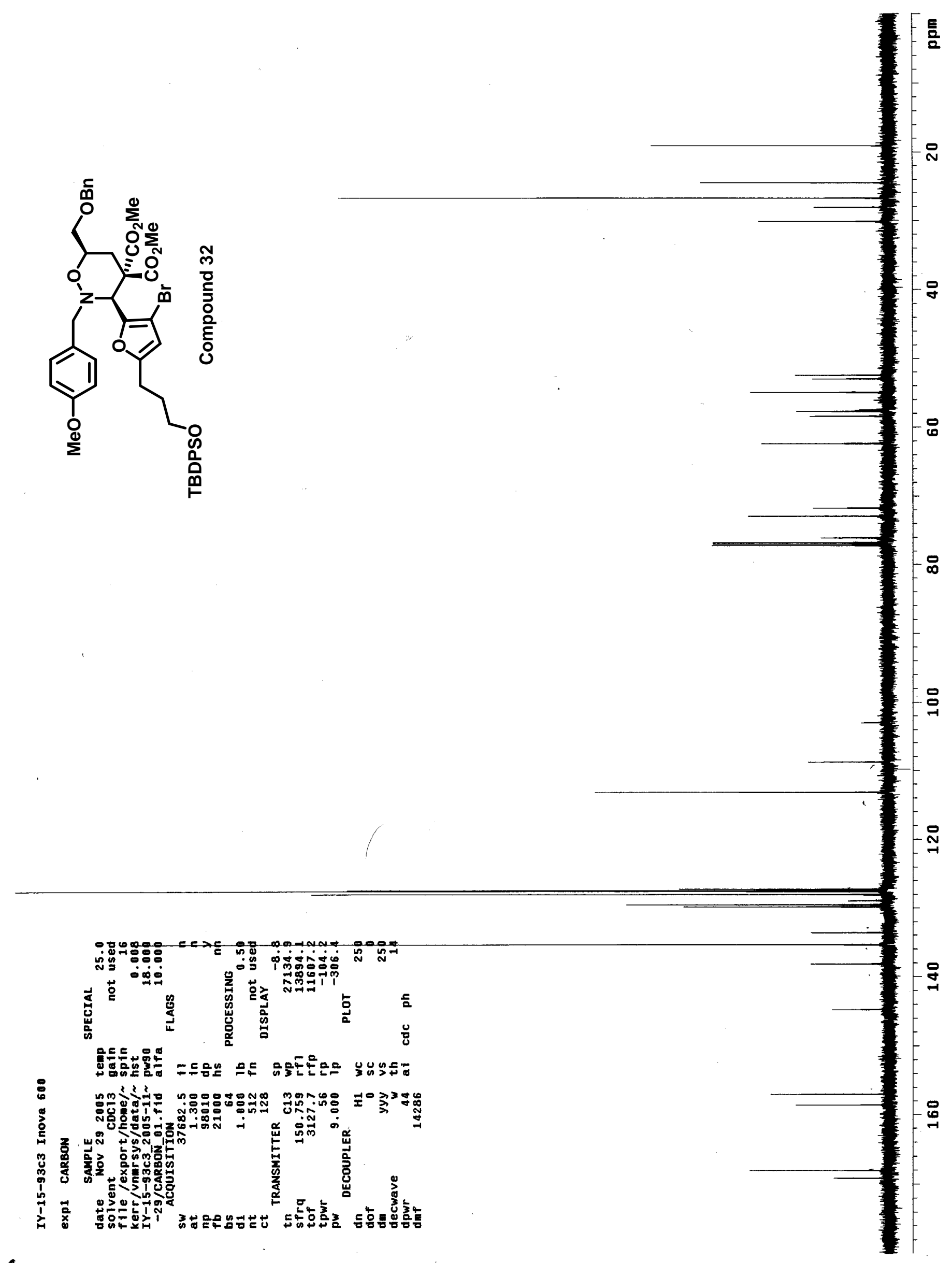

11 


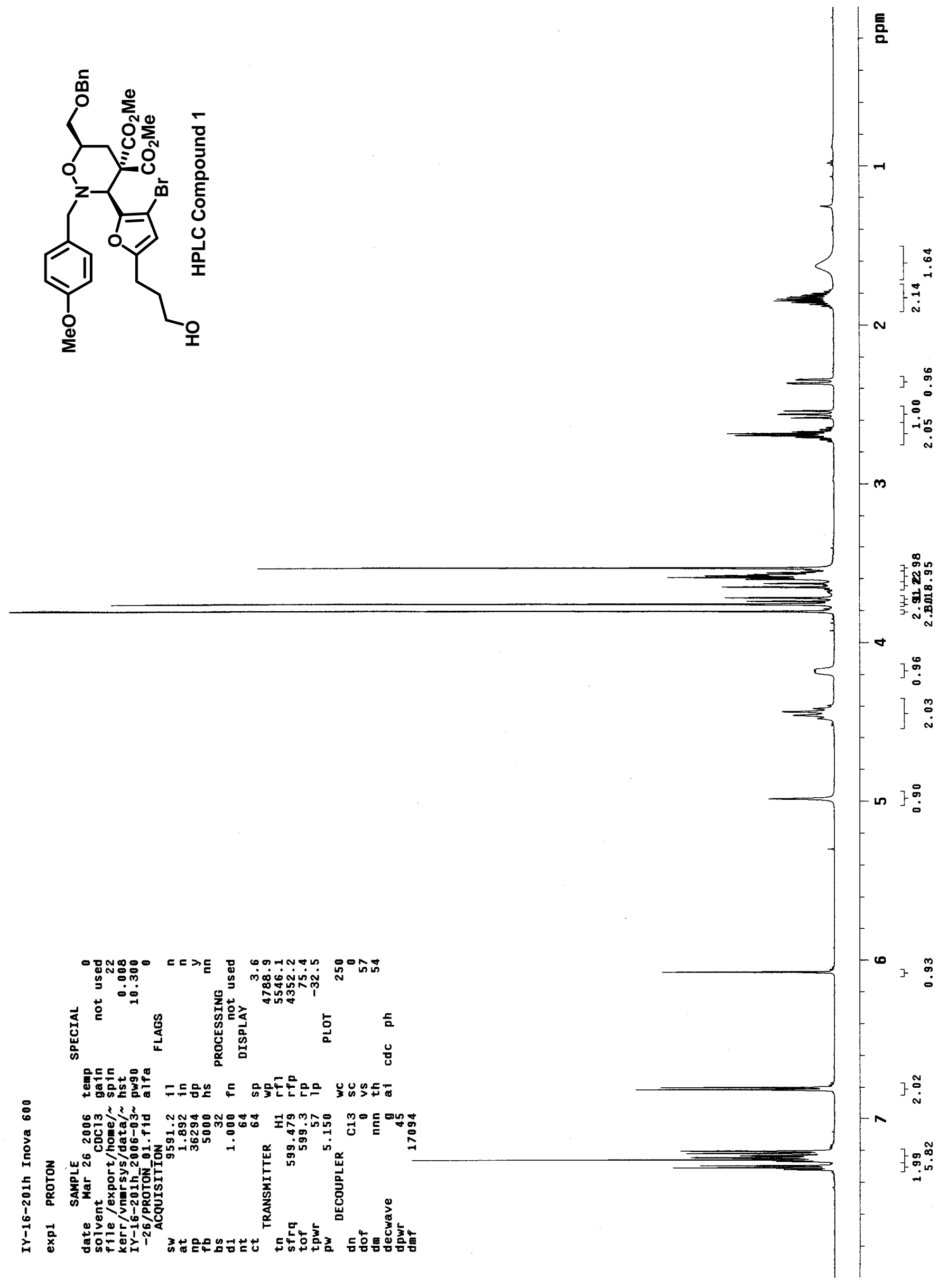



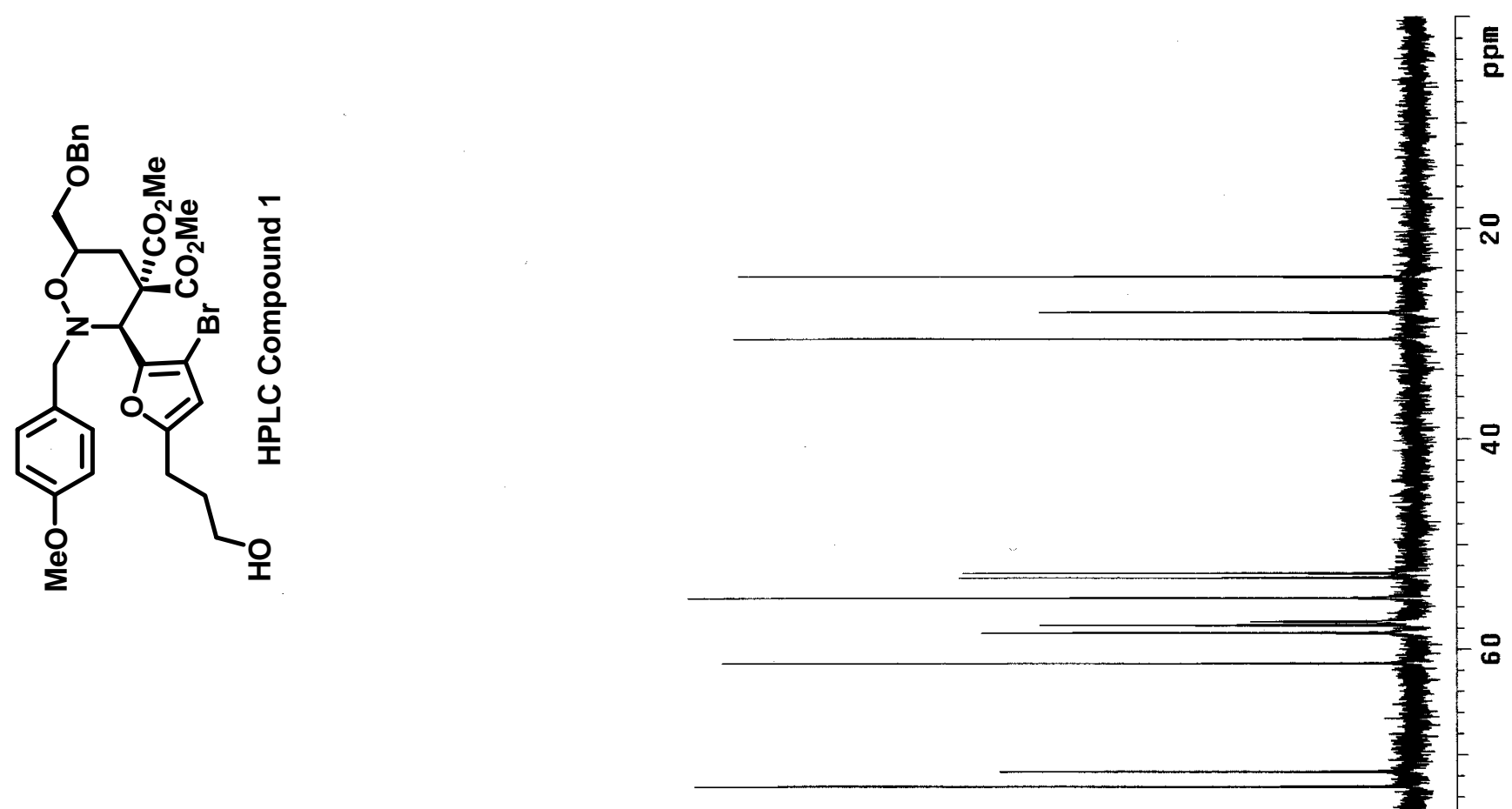

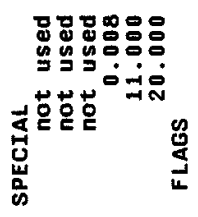
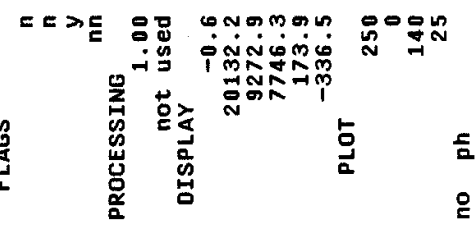

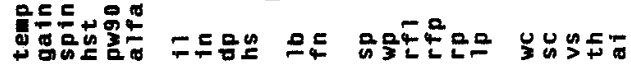

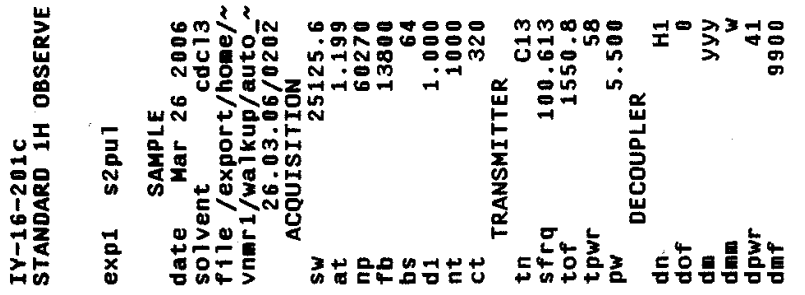




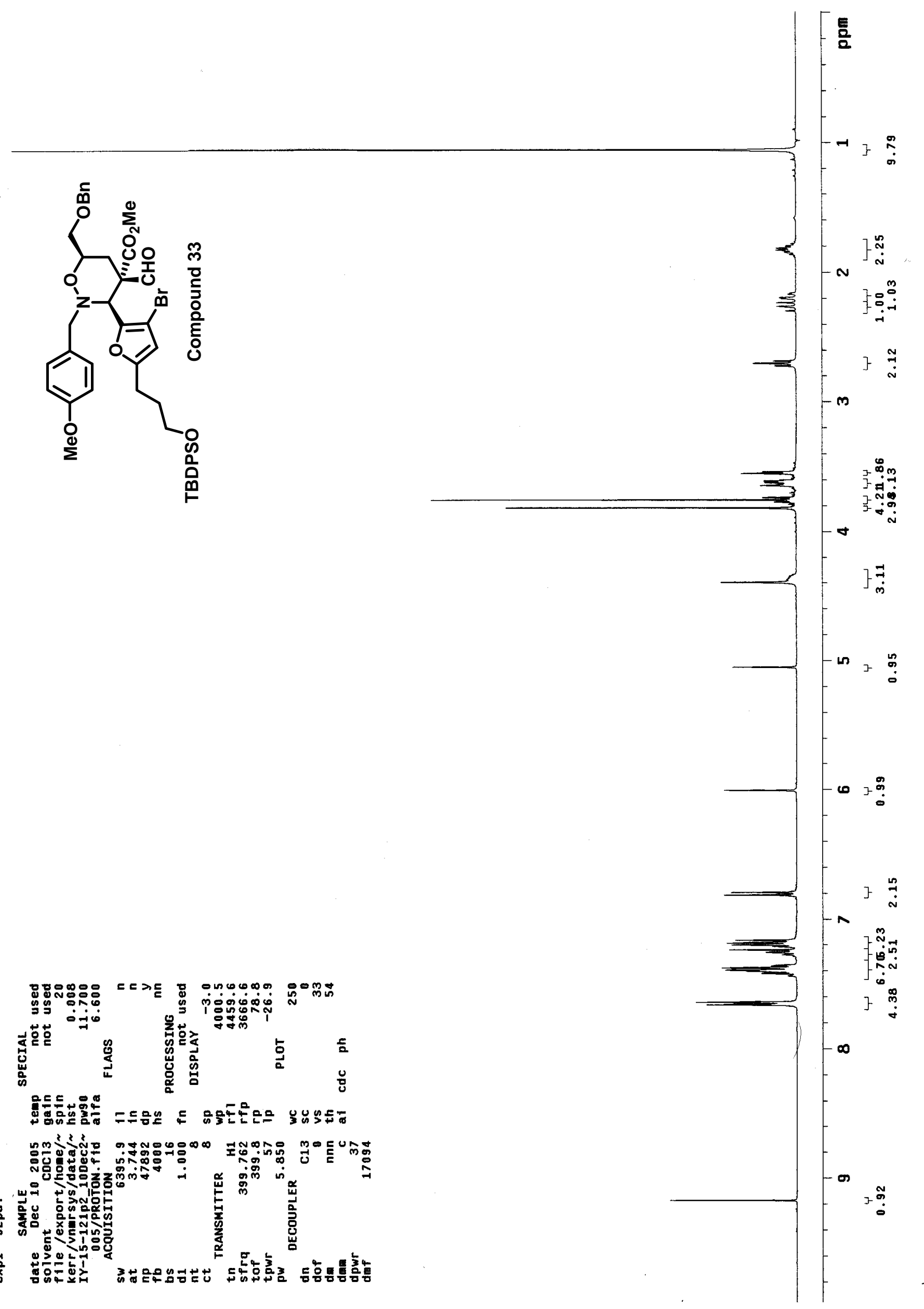



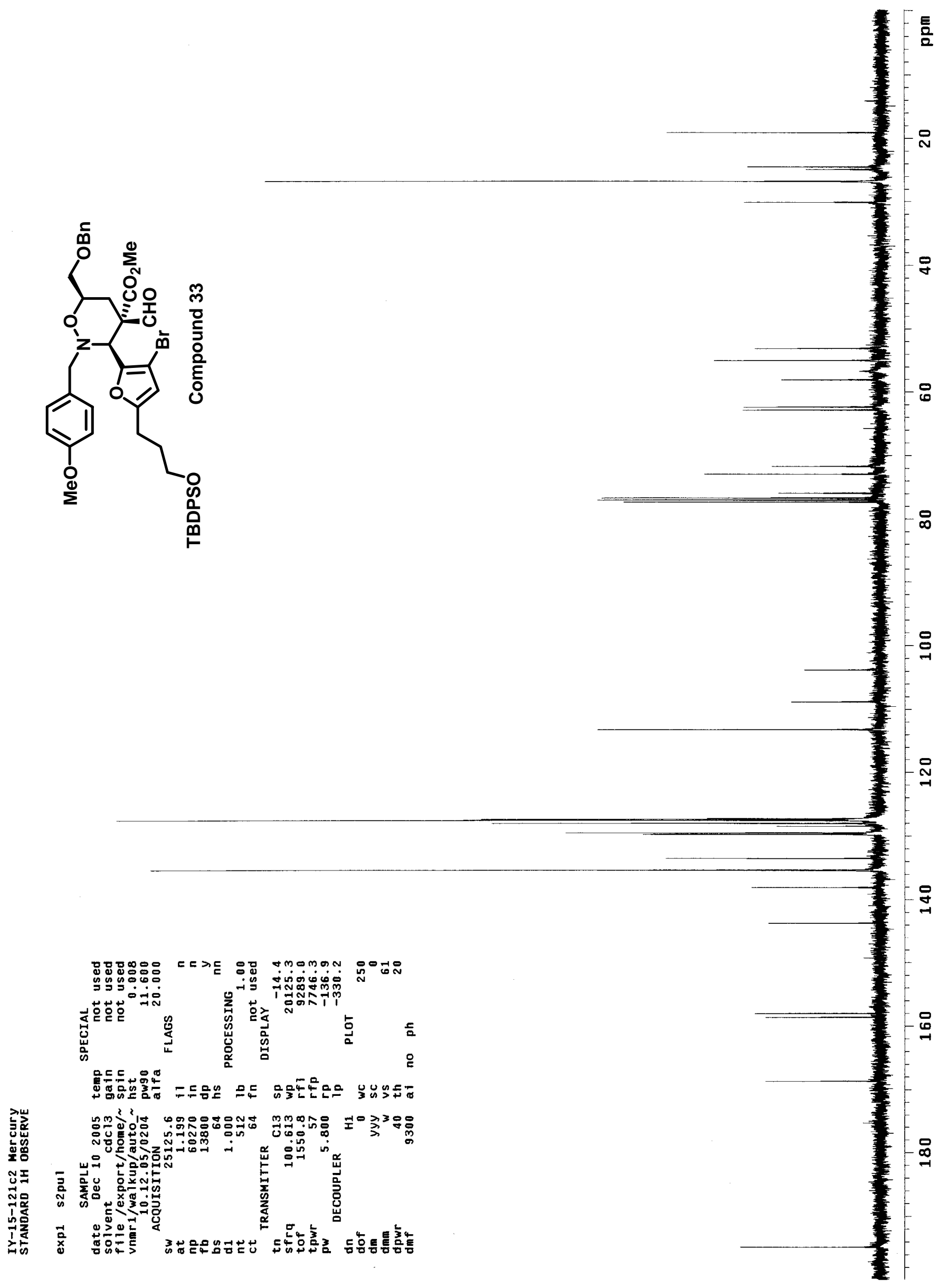


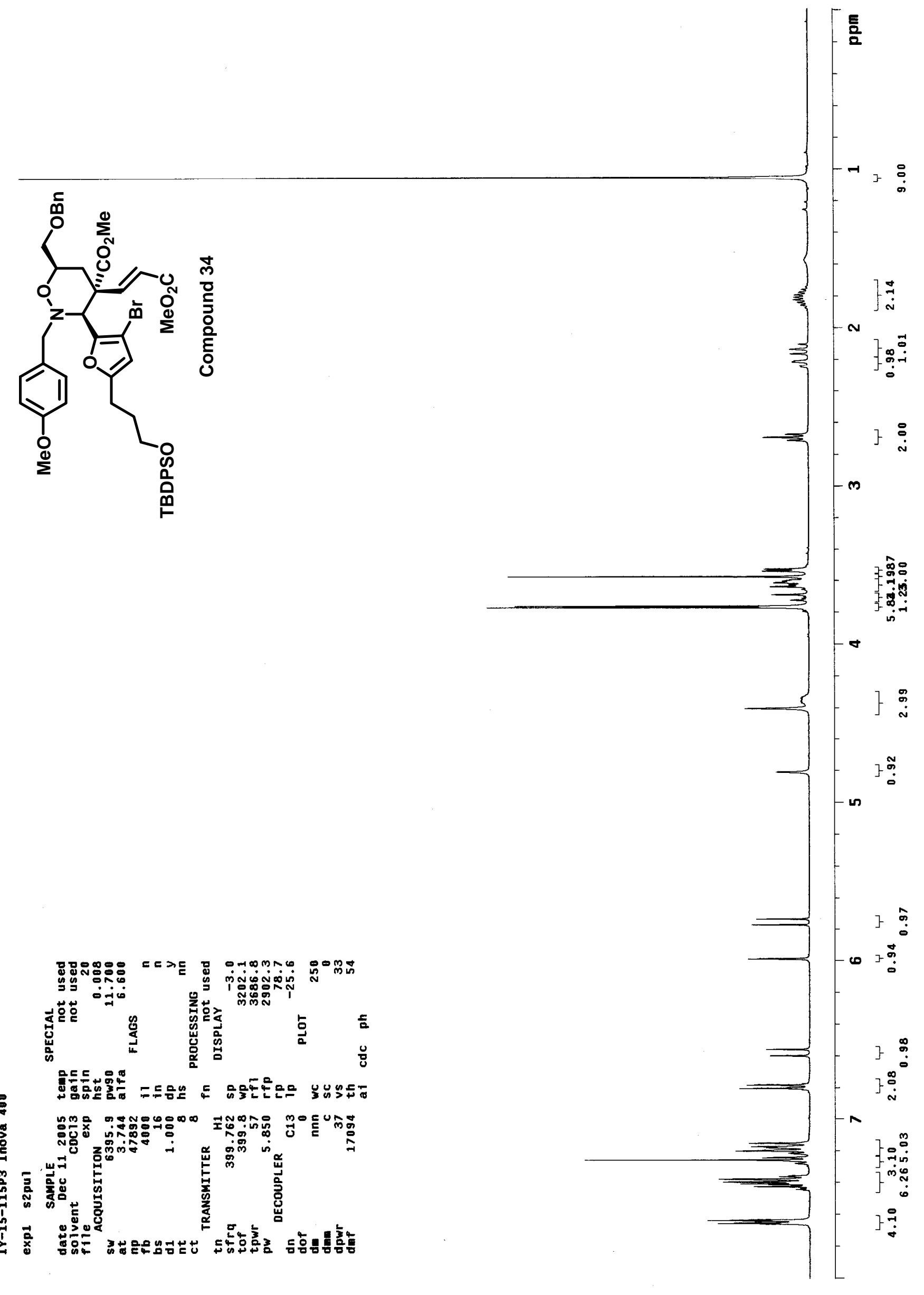




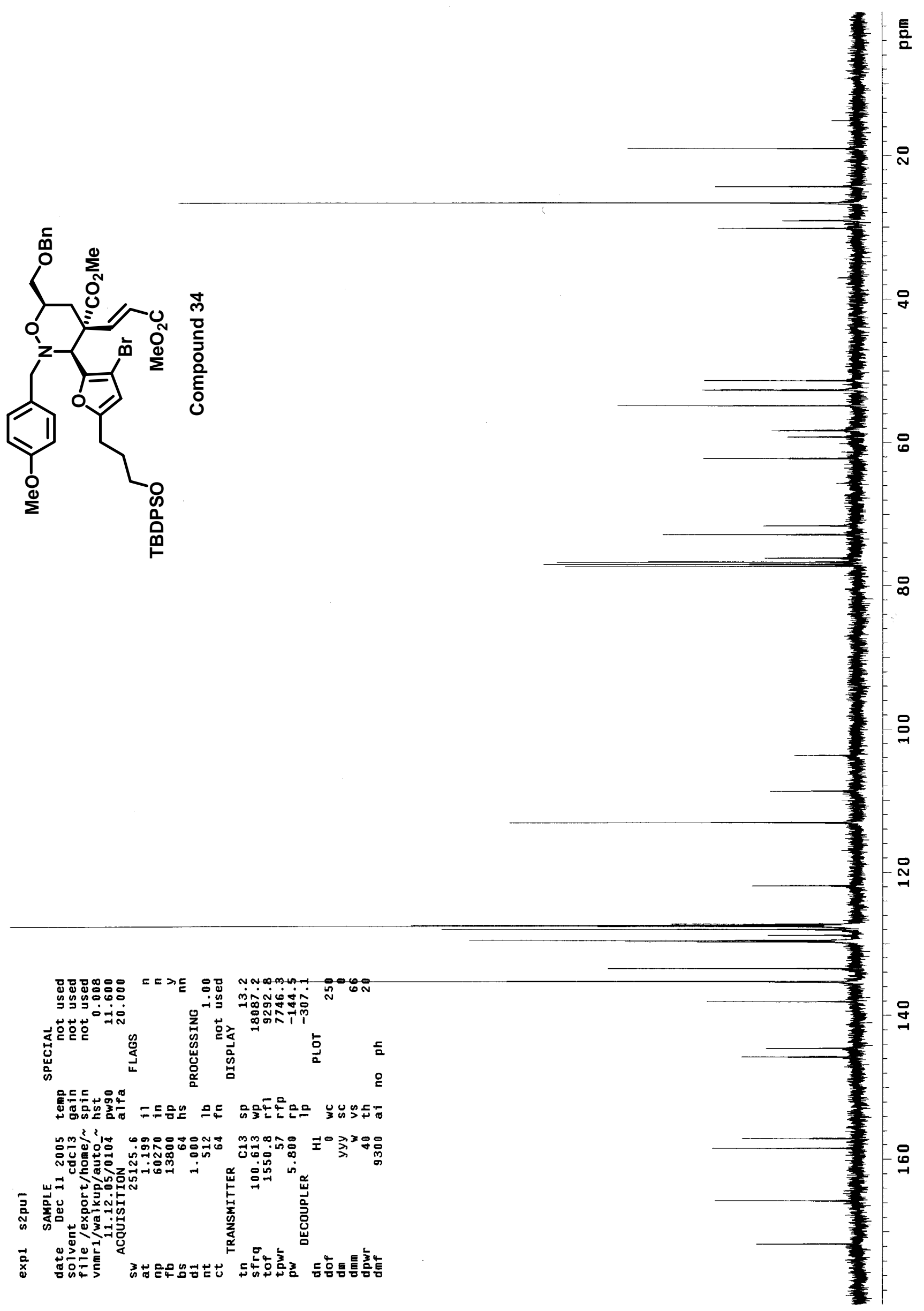




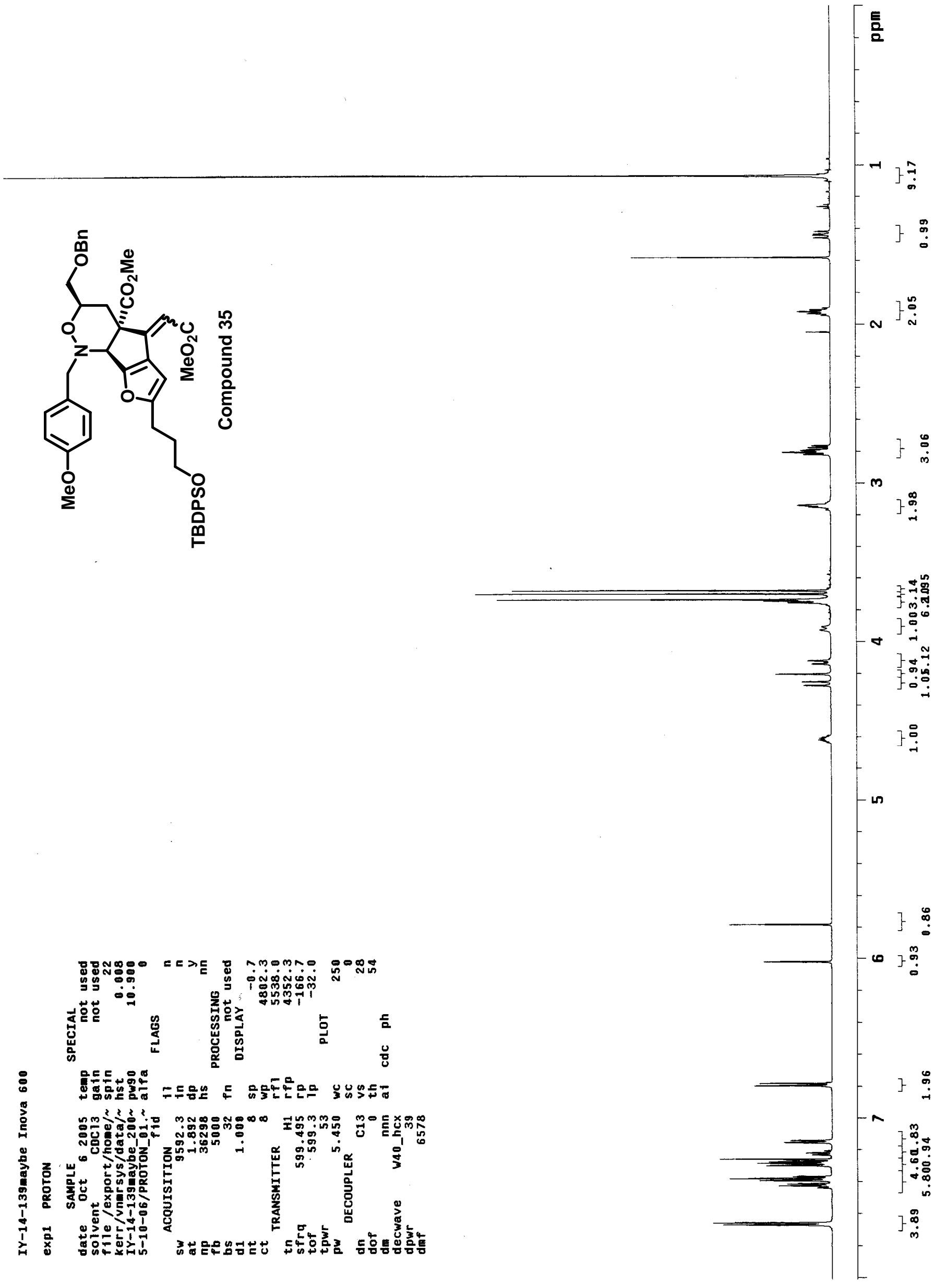




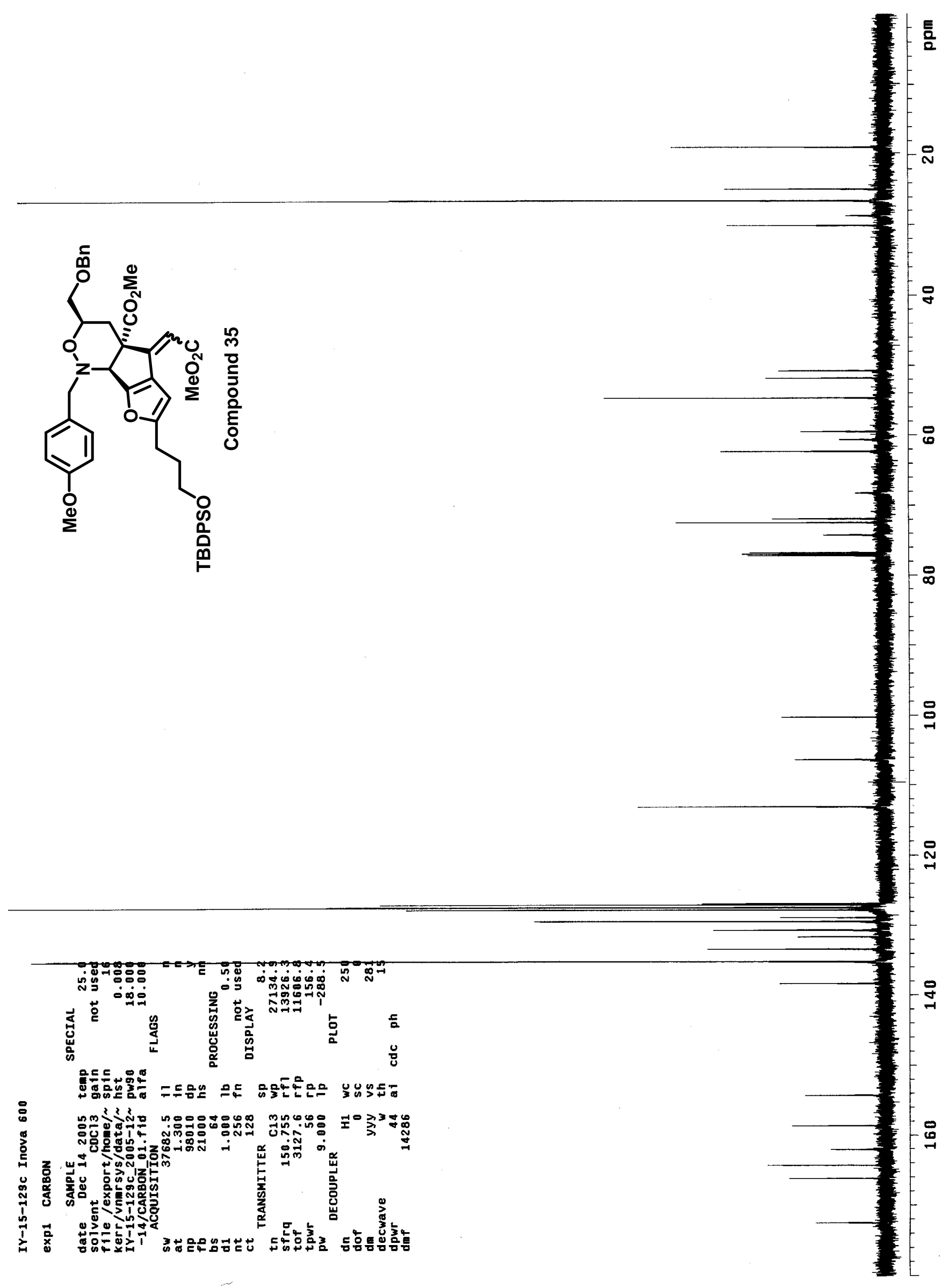




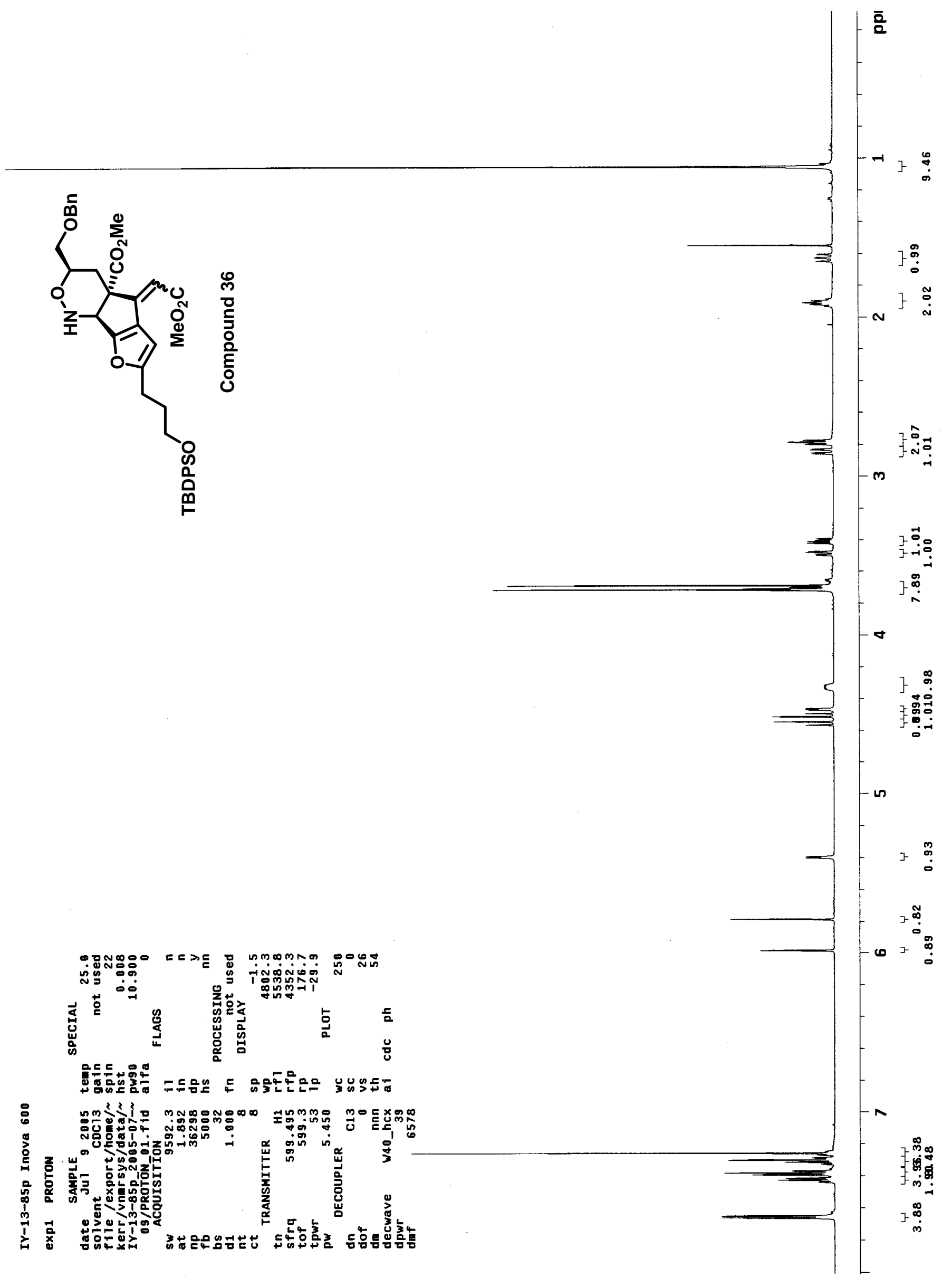




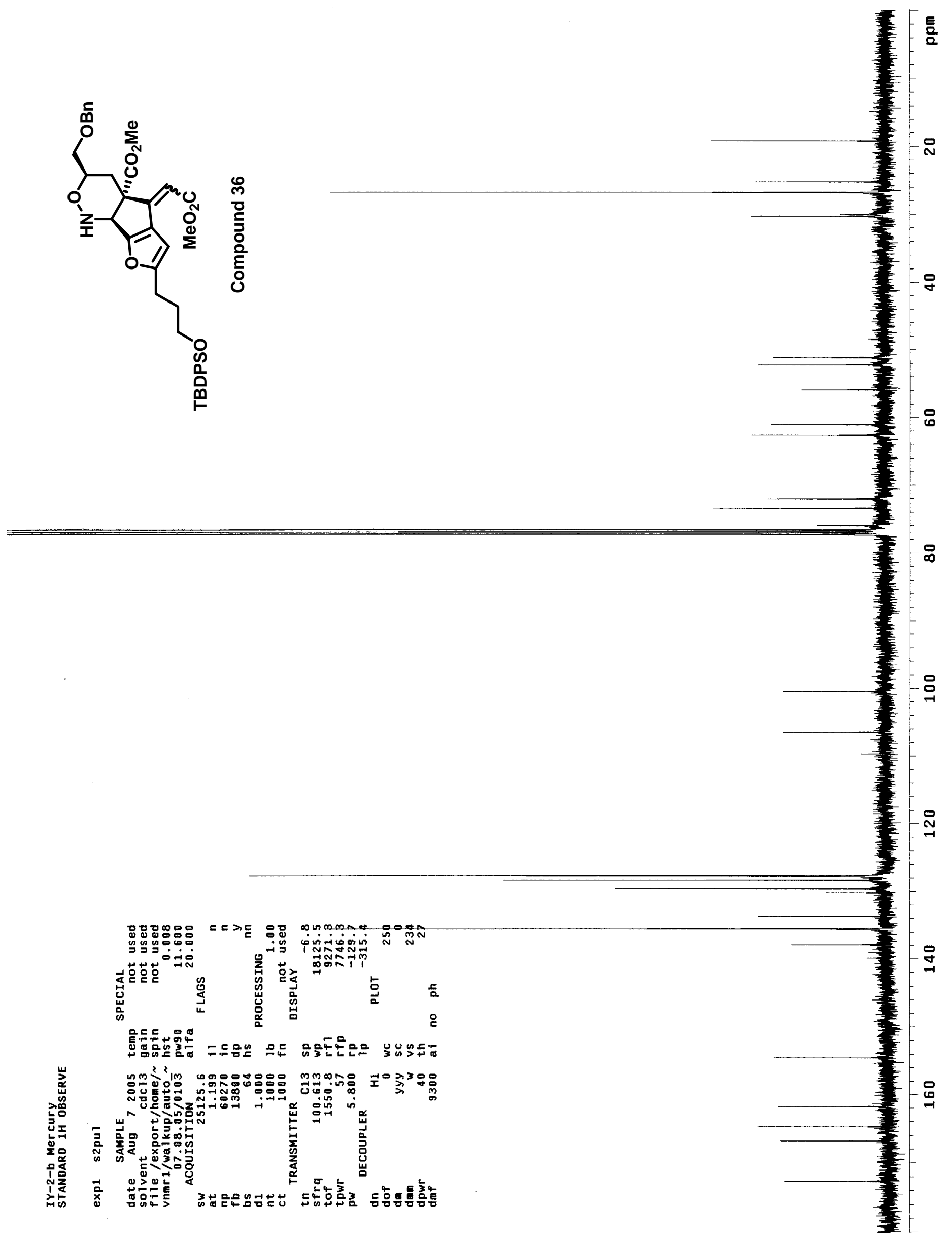




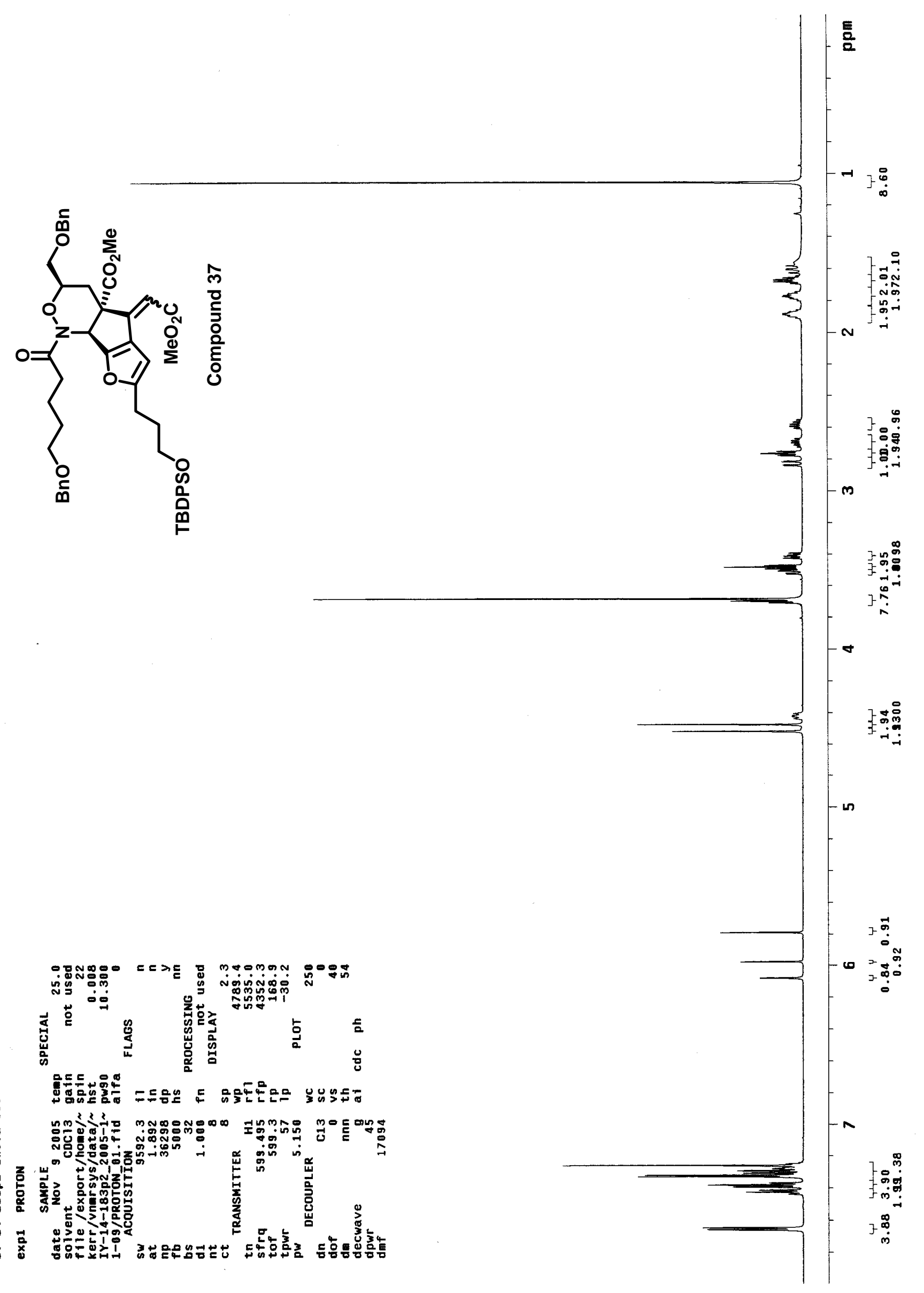




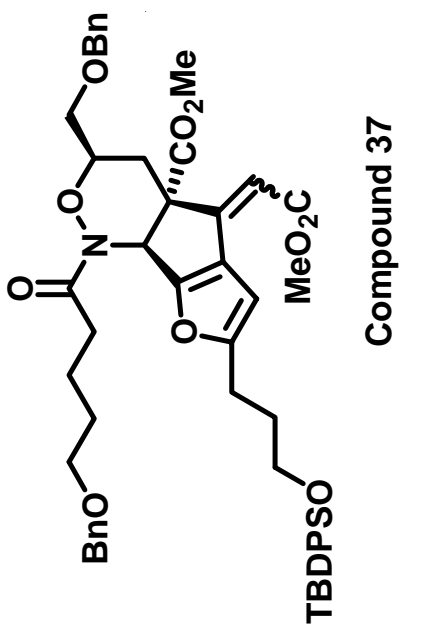

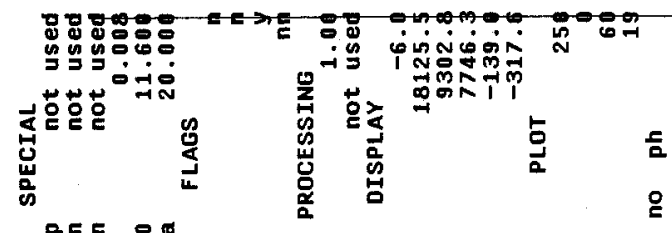

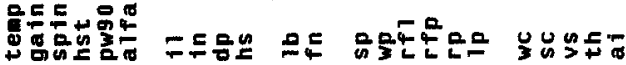

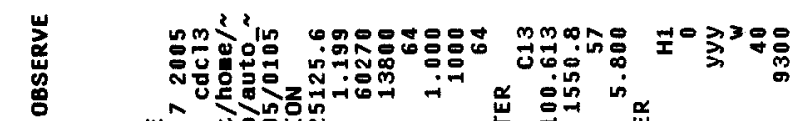

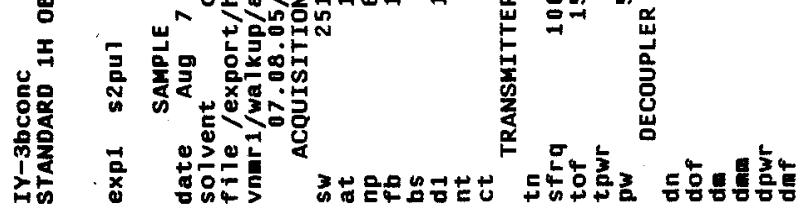




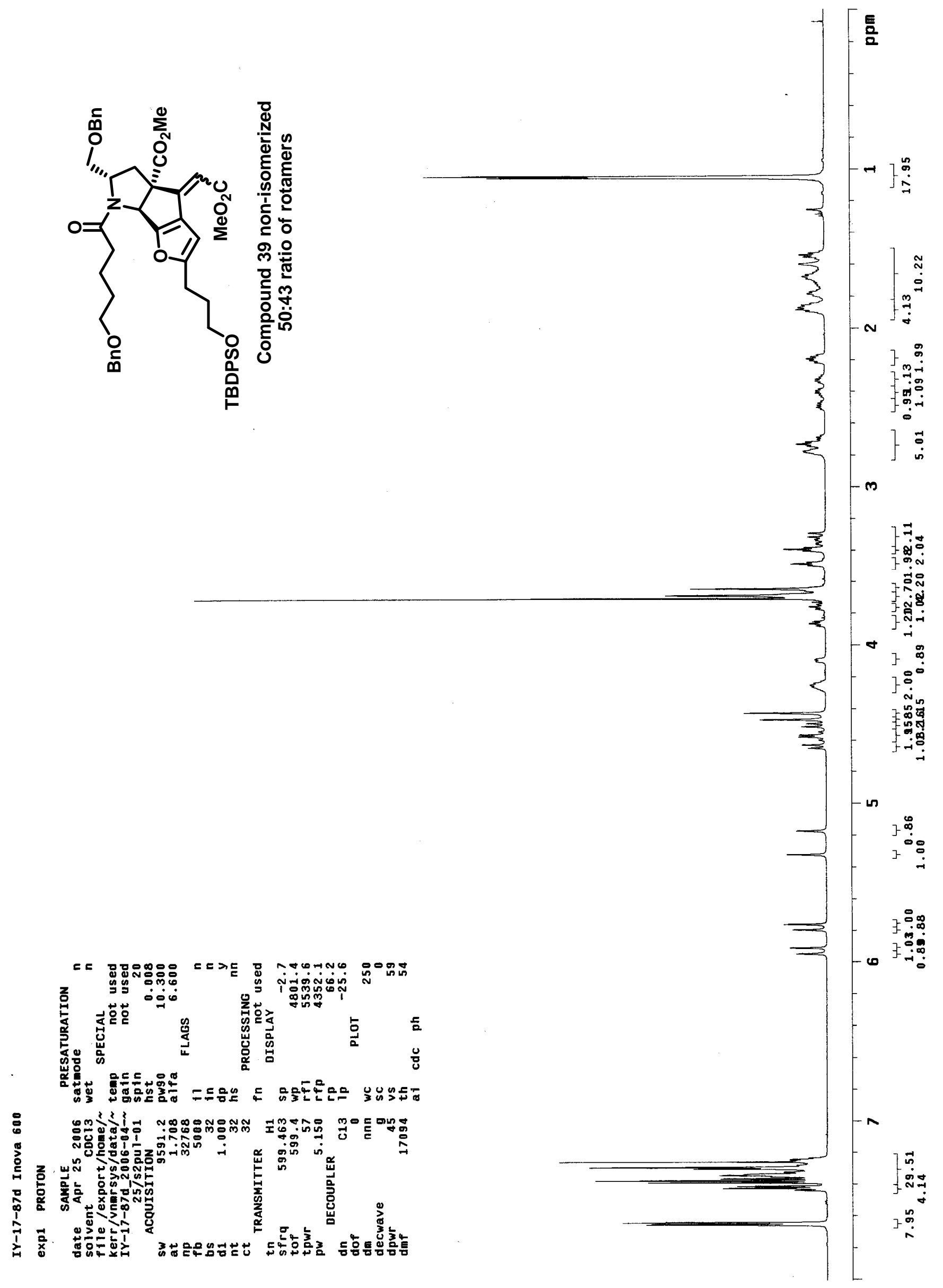




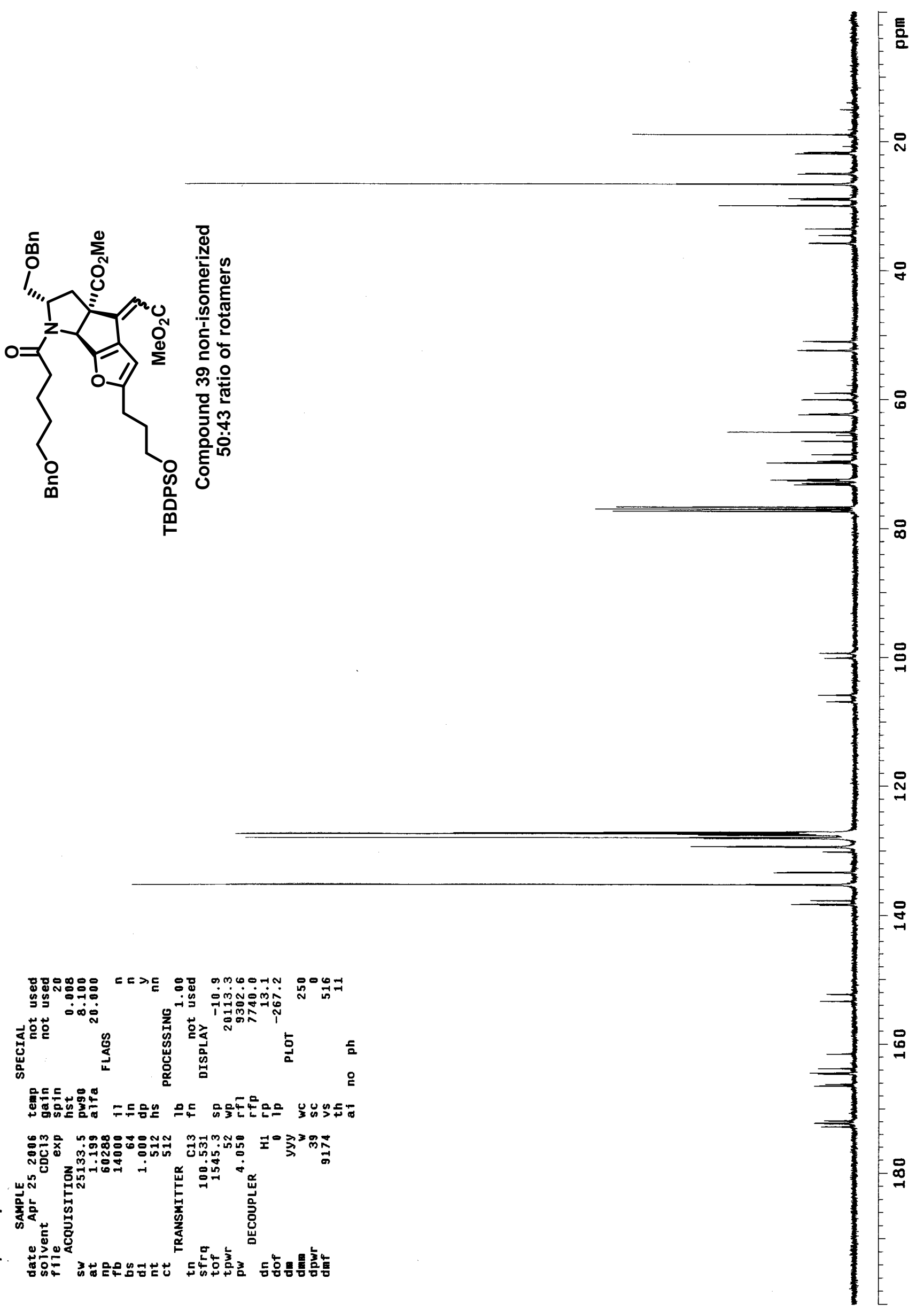




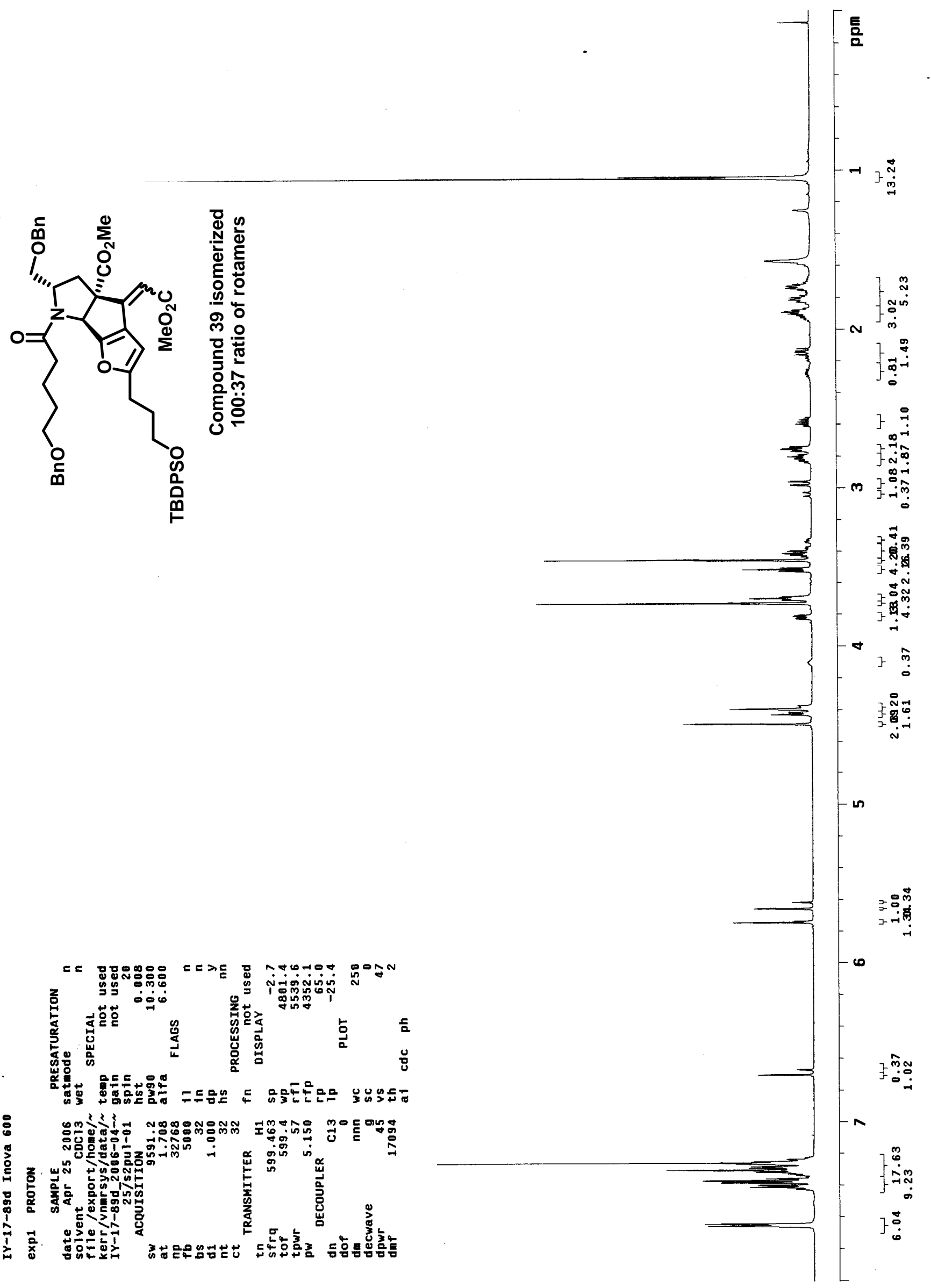




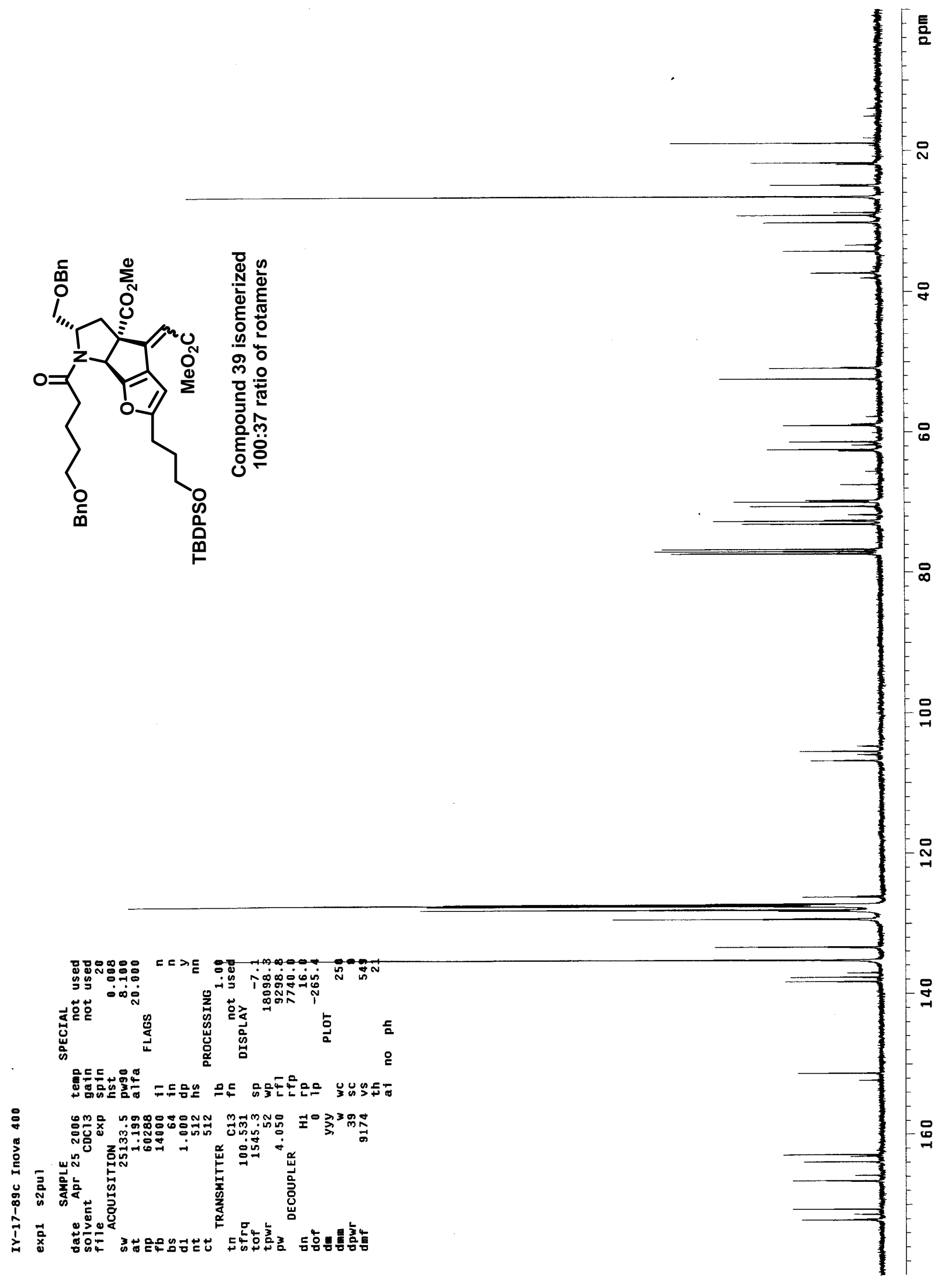




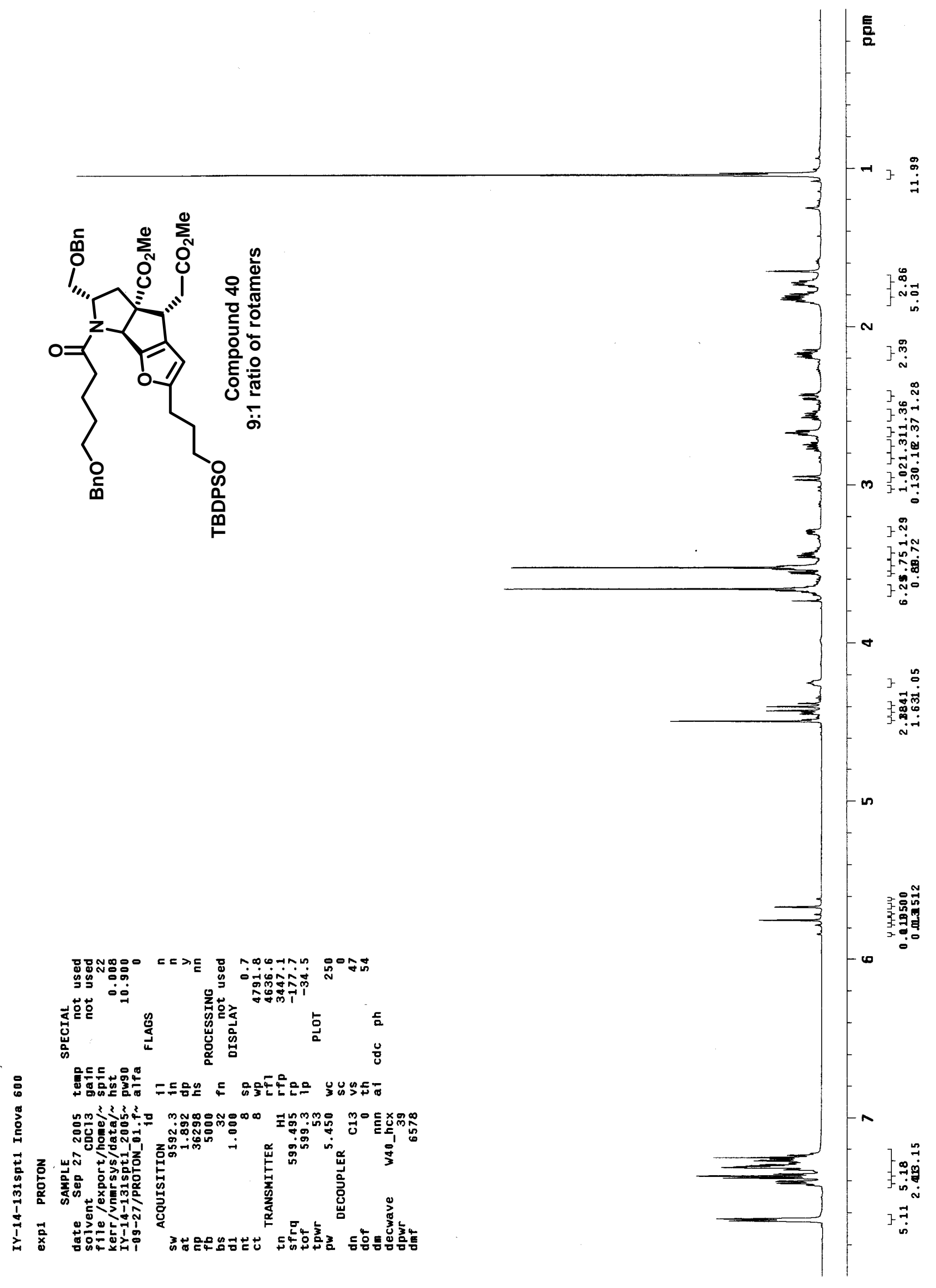




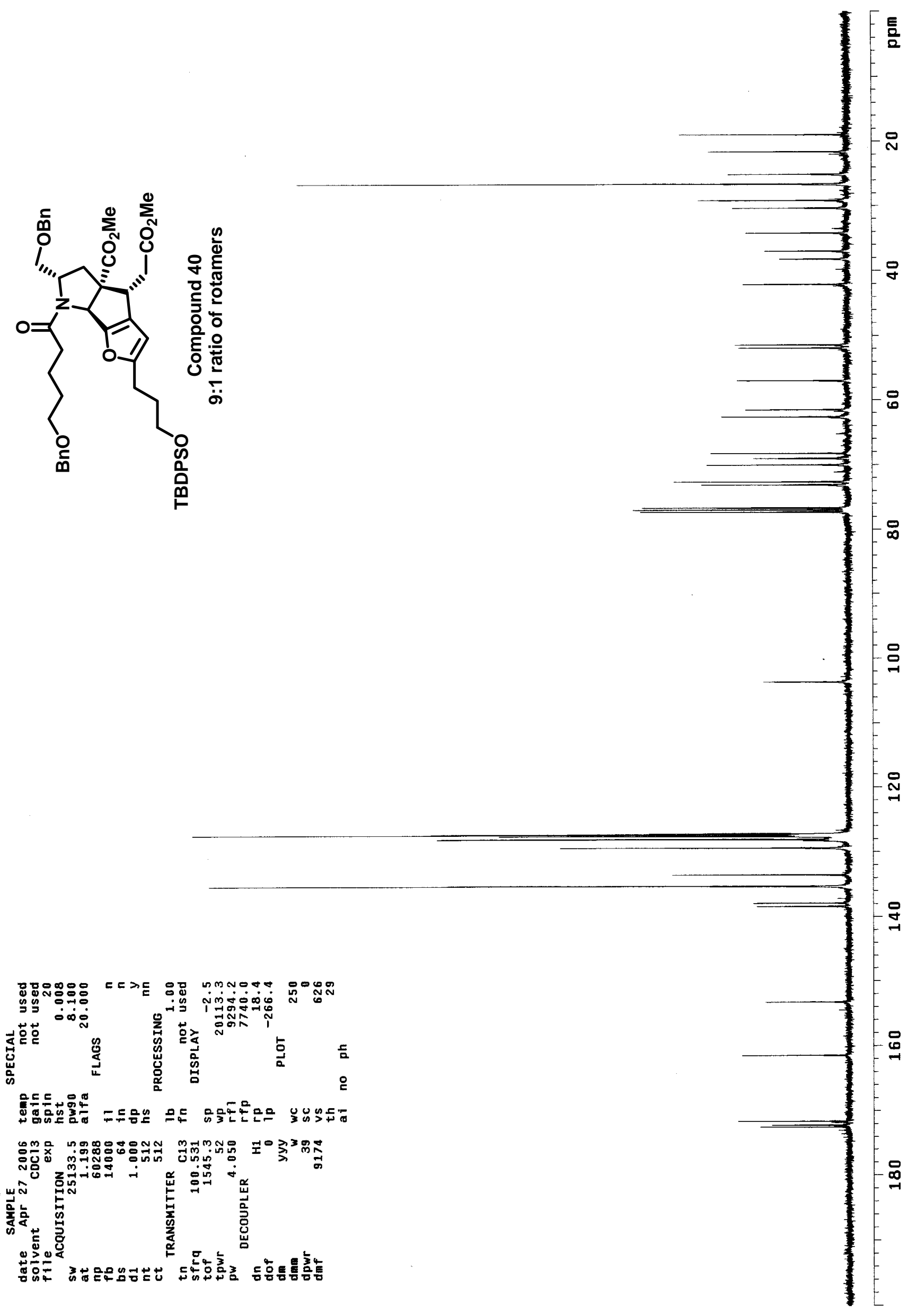




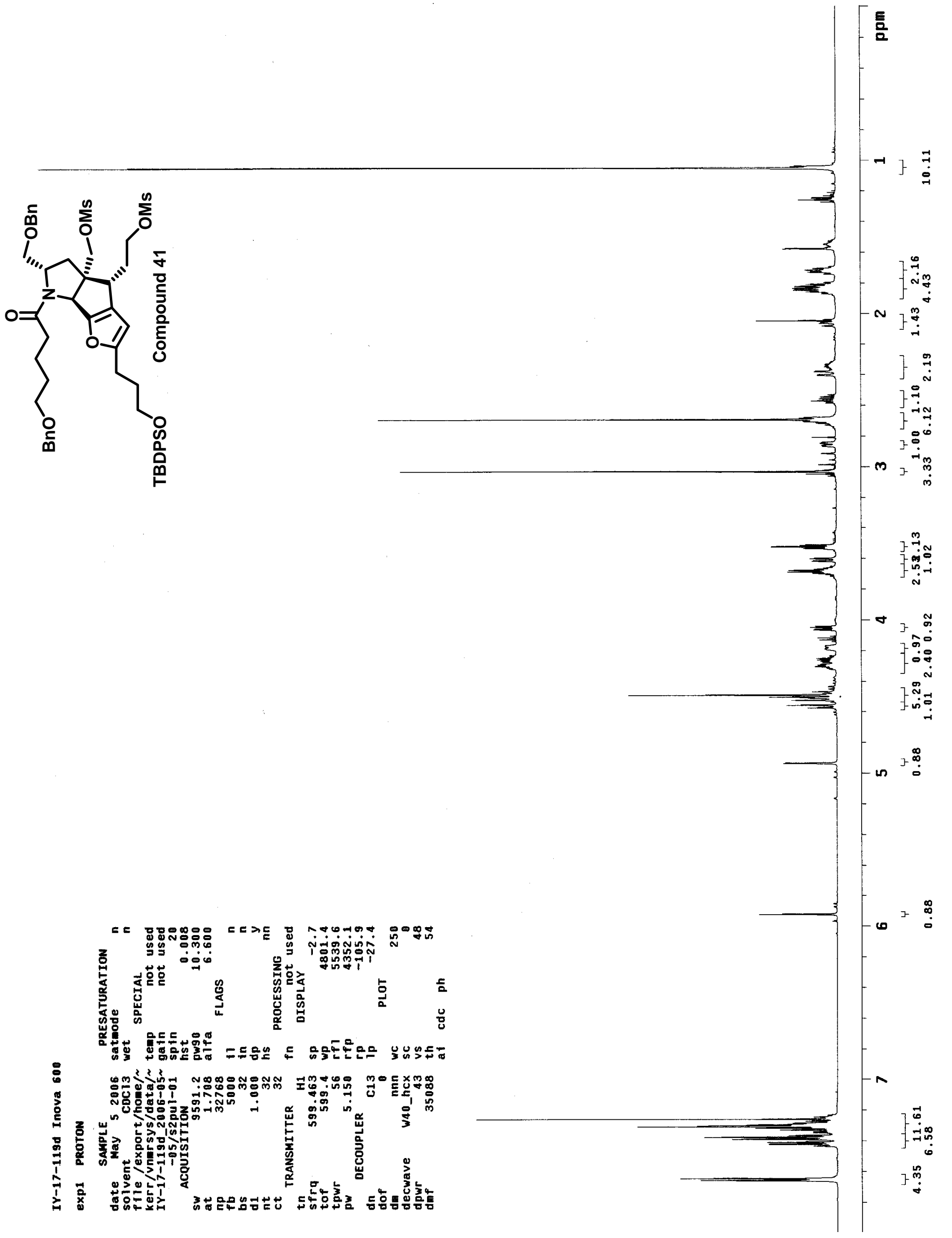




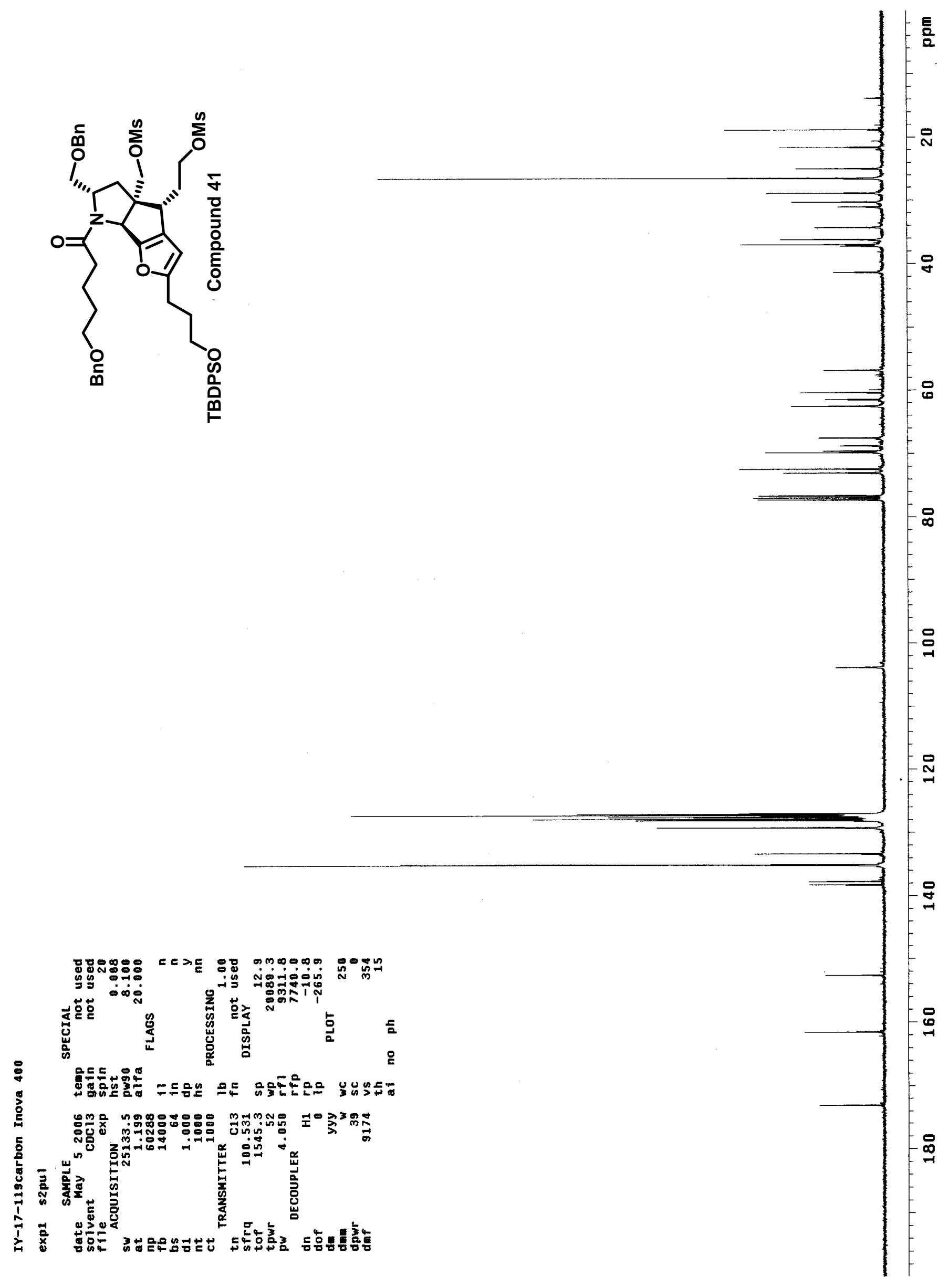




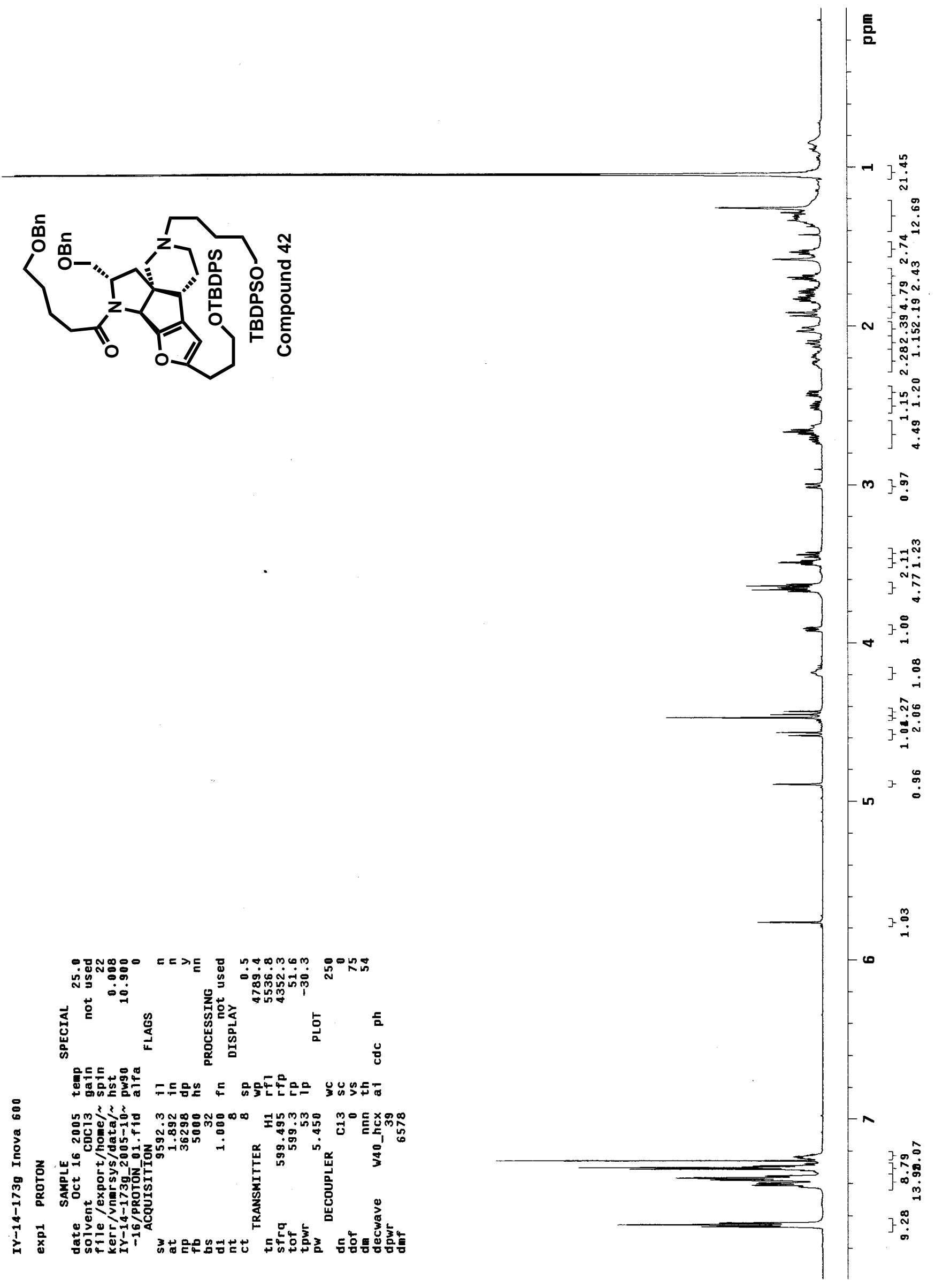




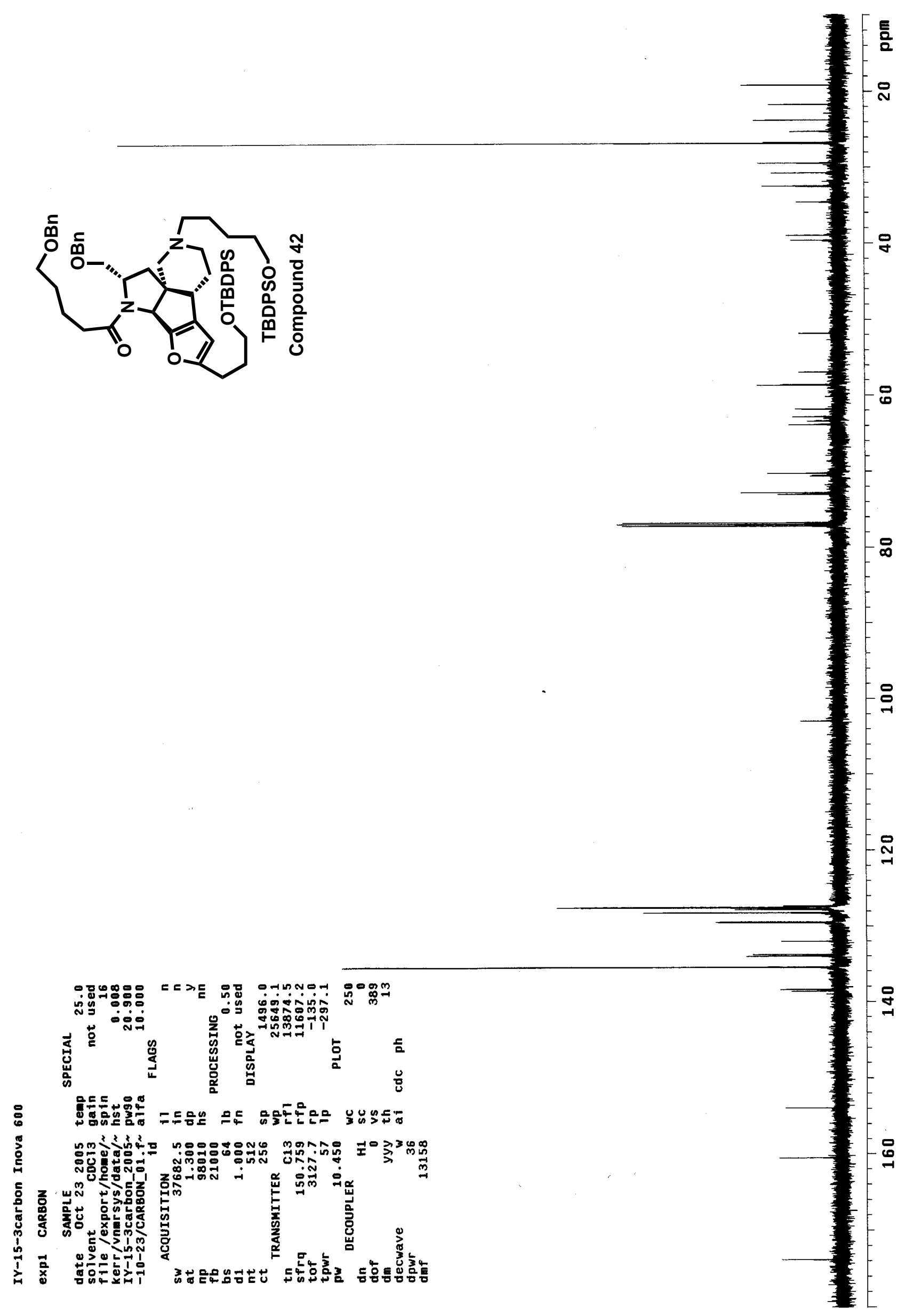




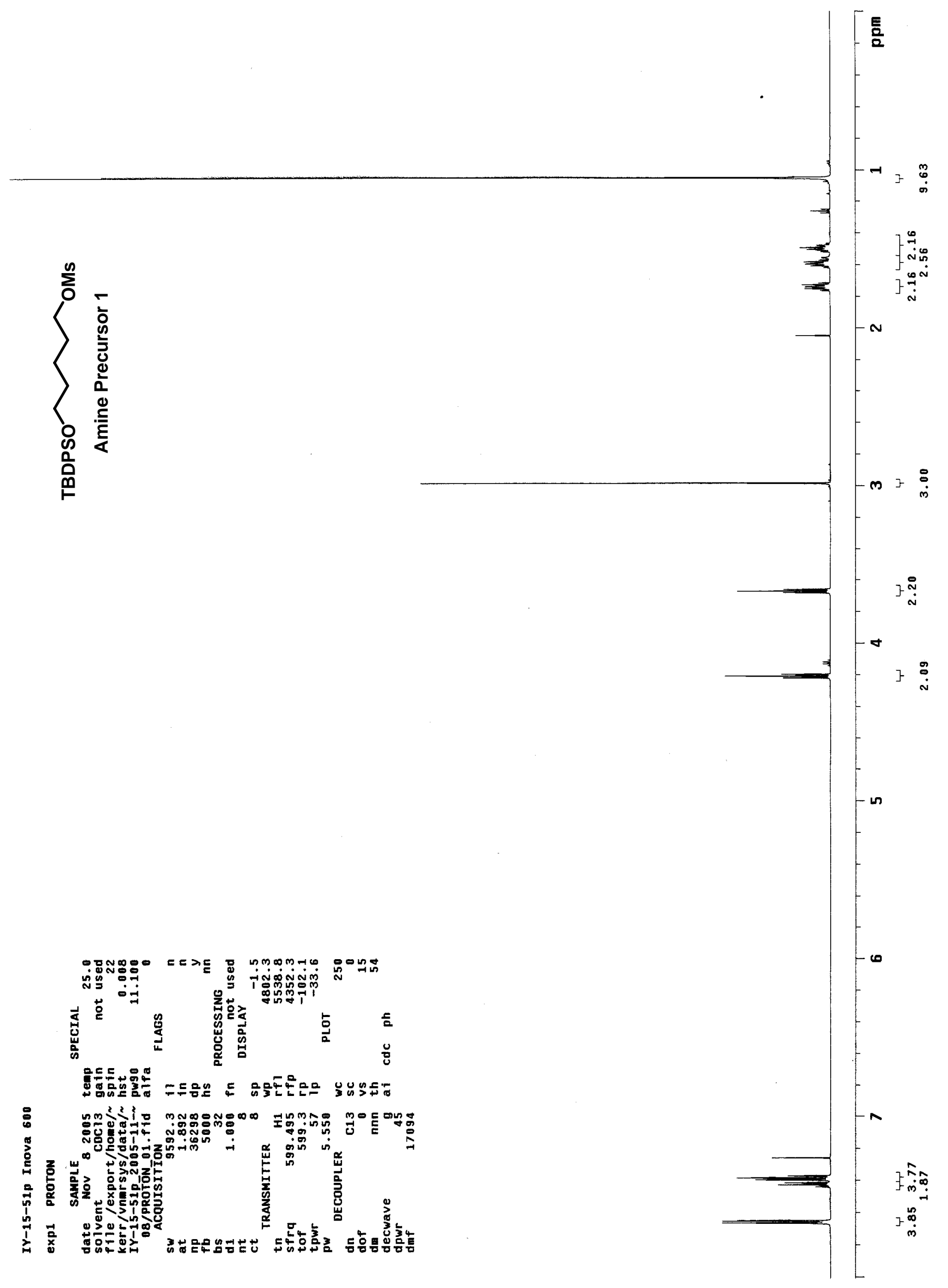




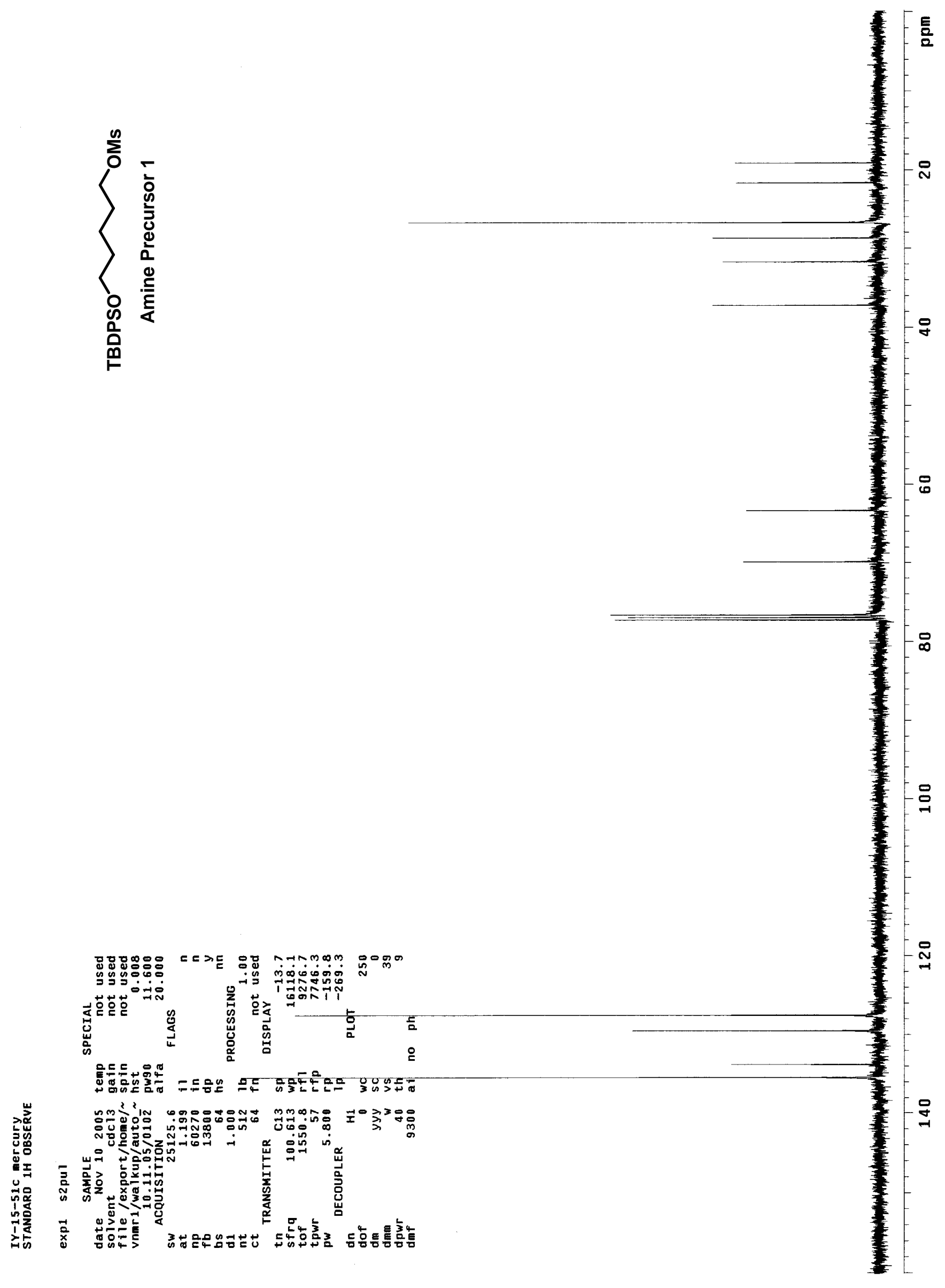




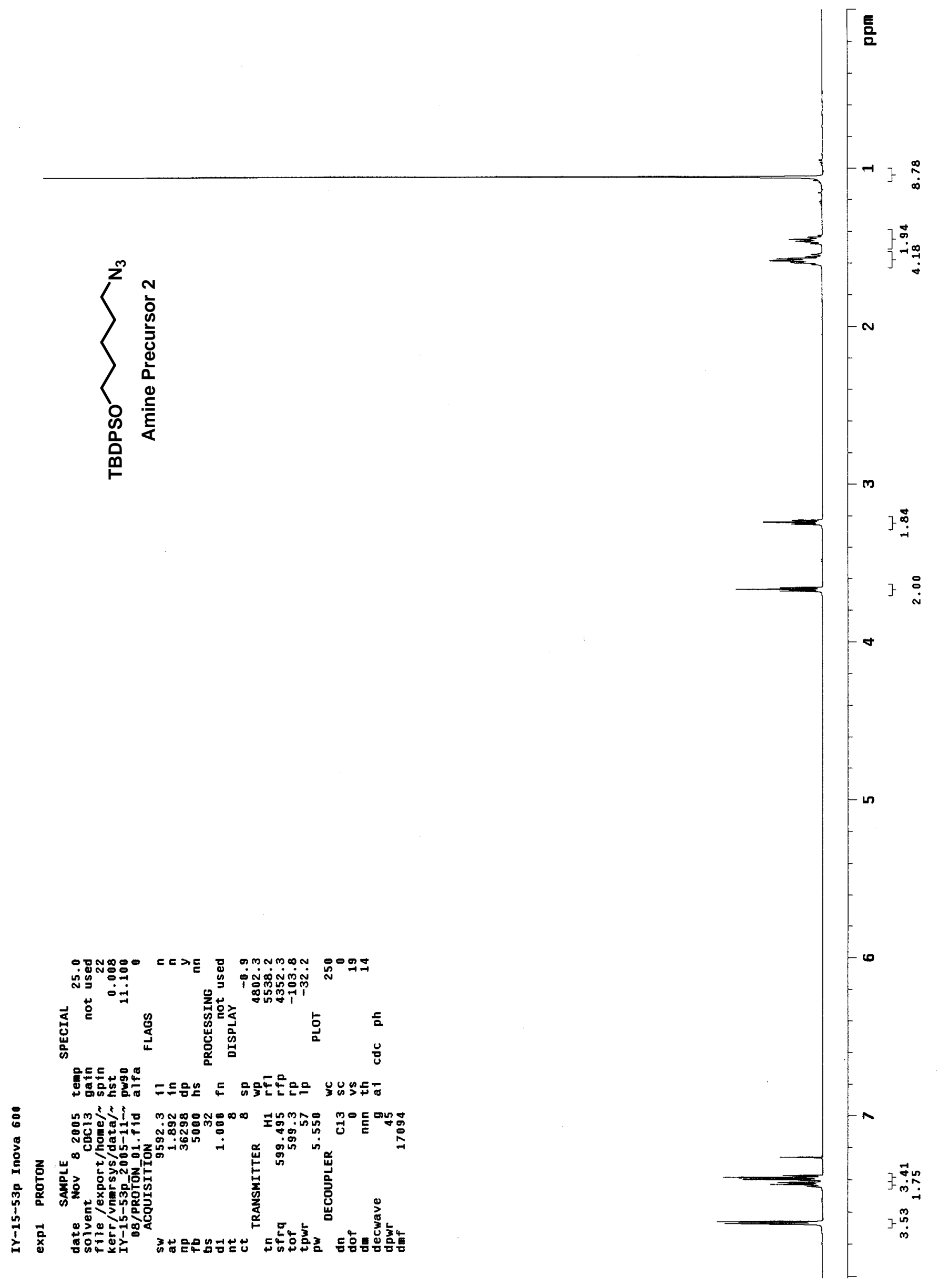




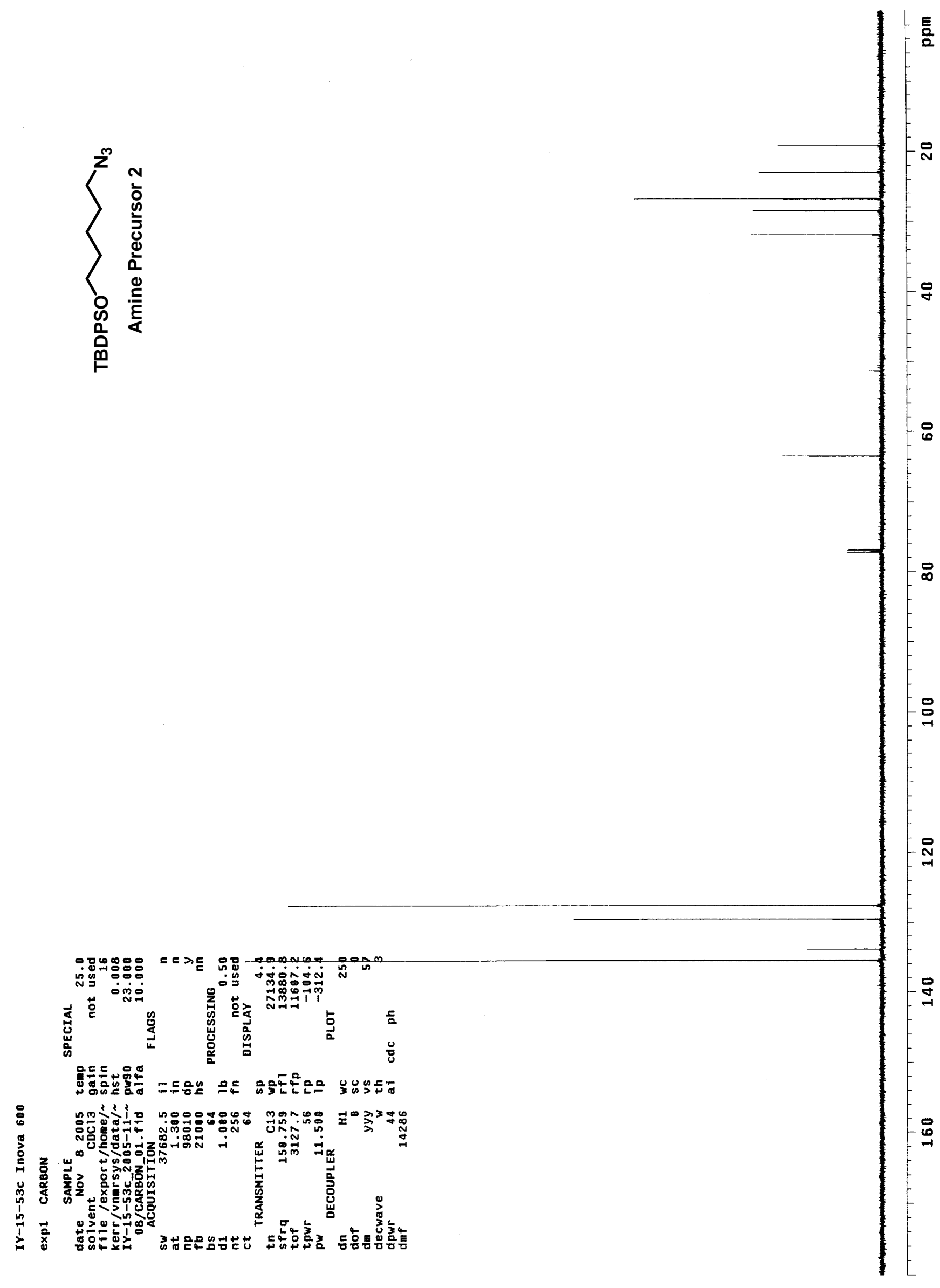




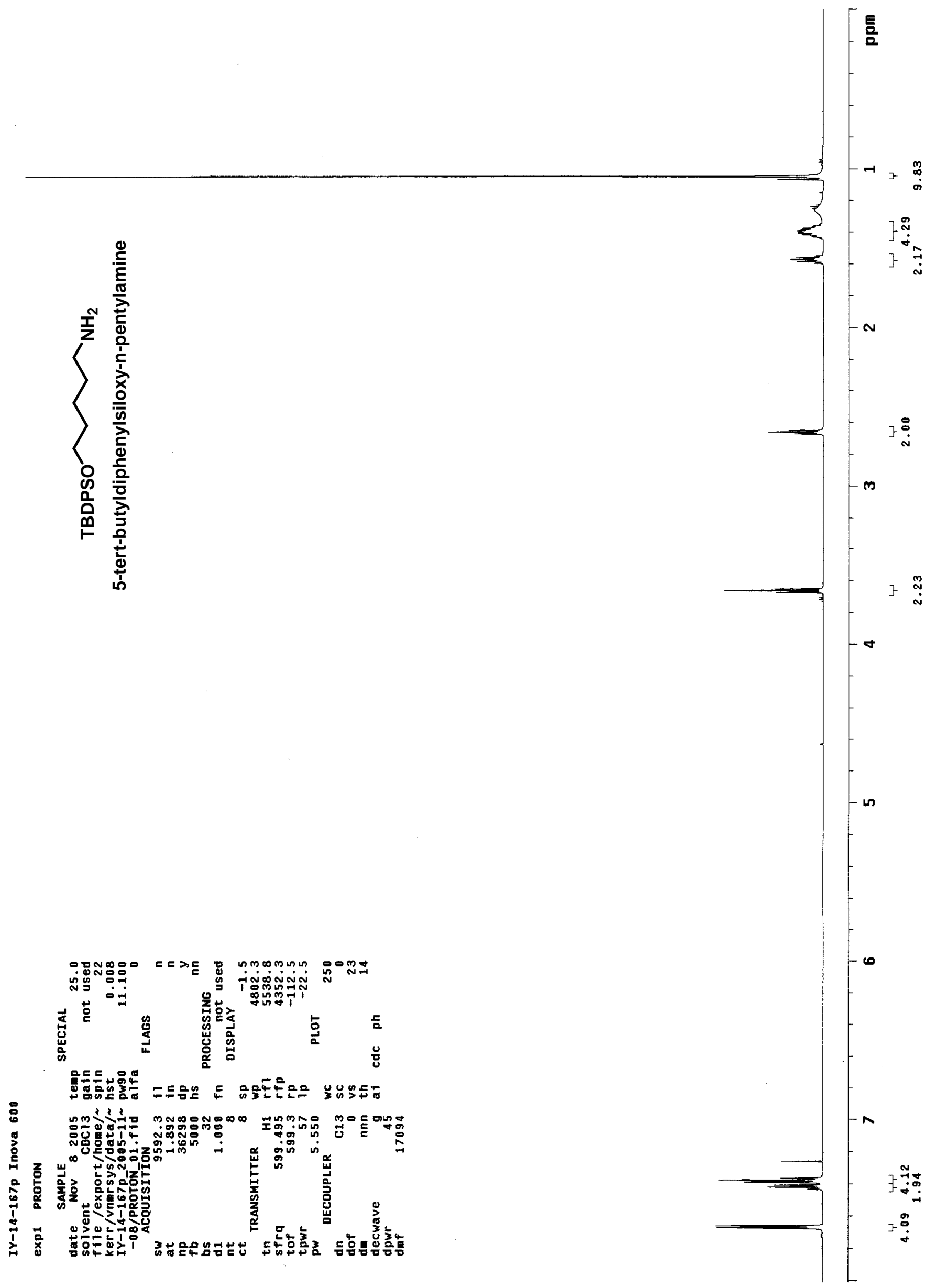




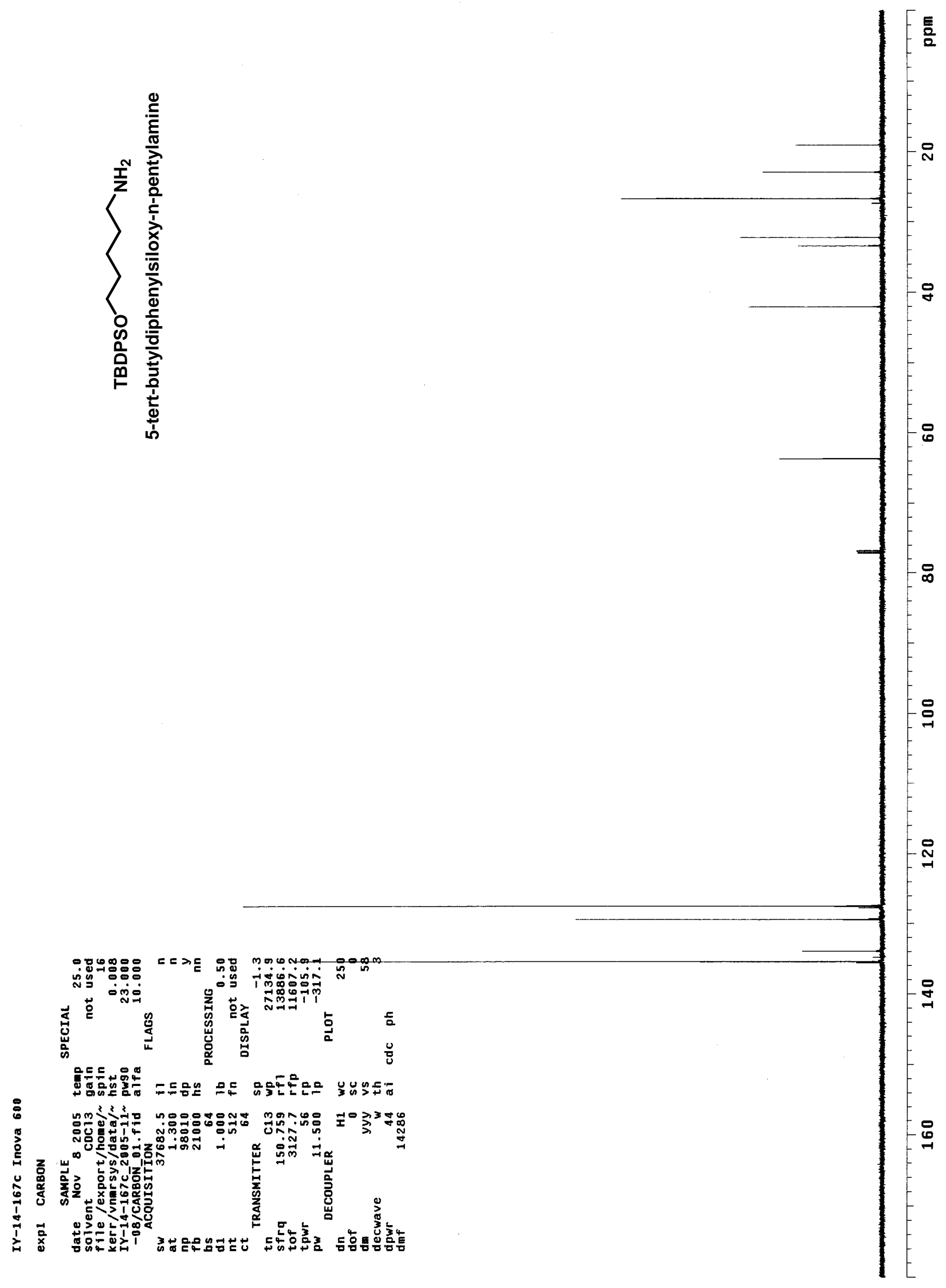




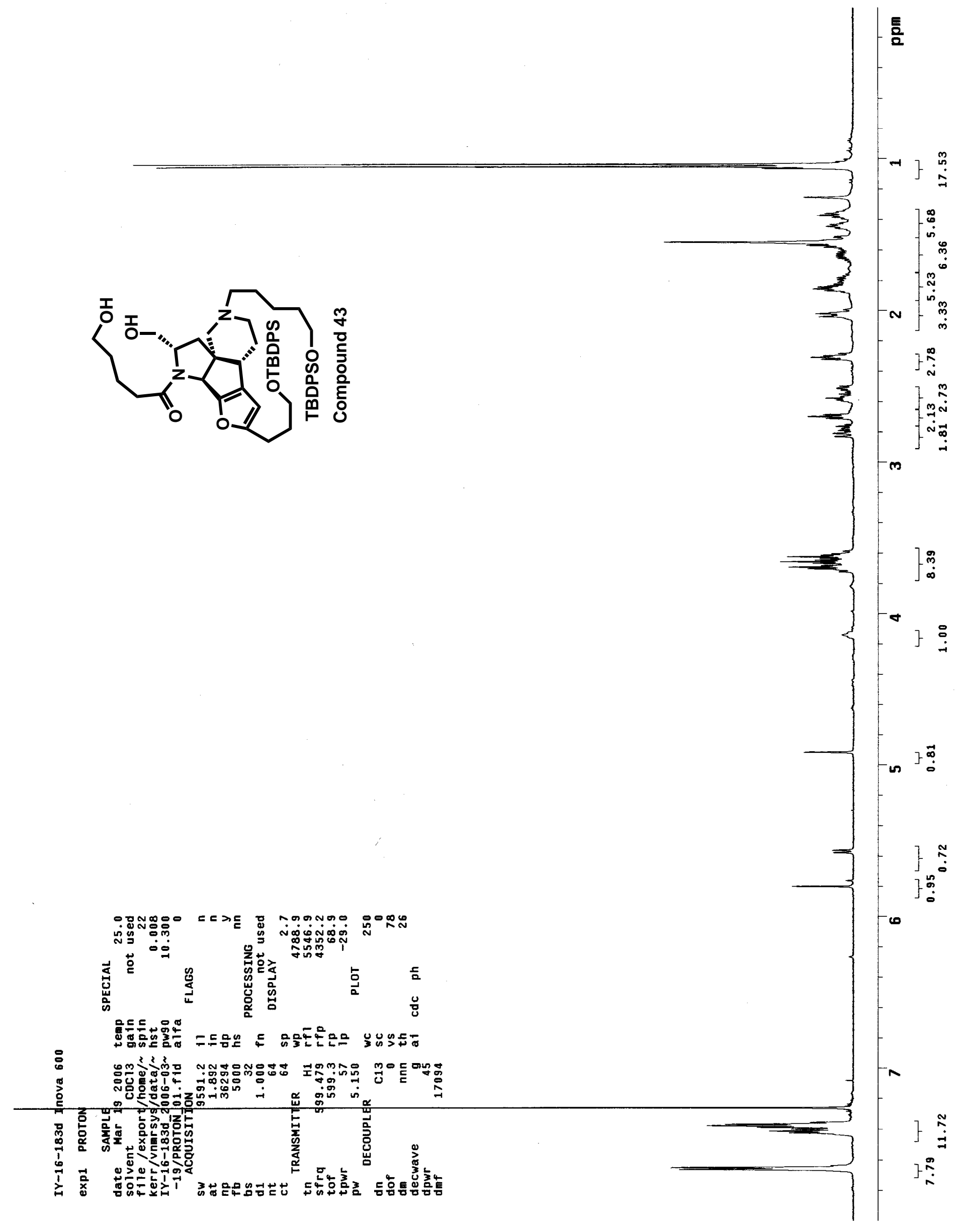




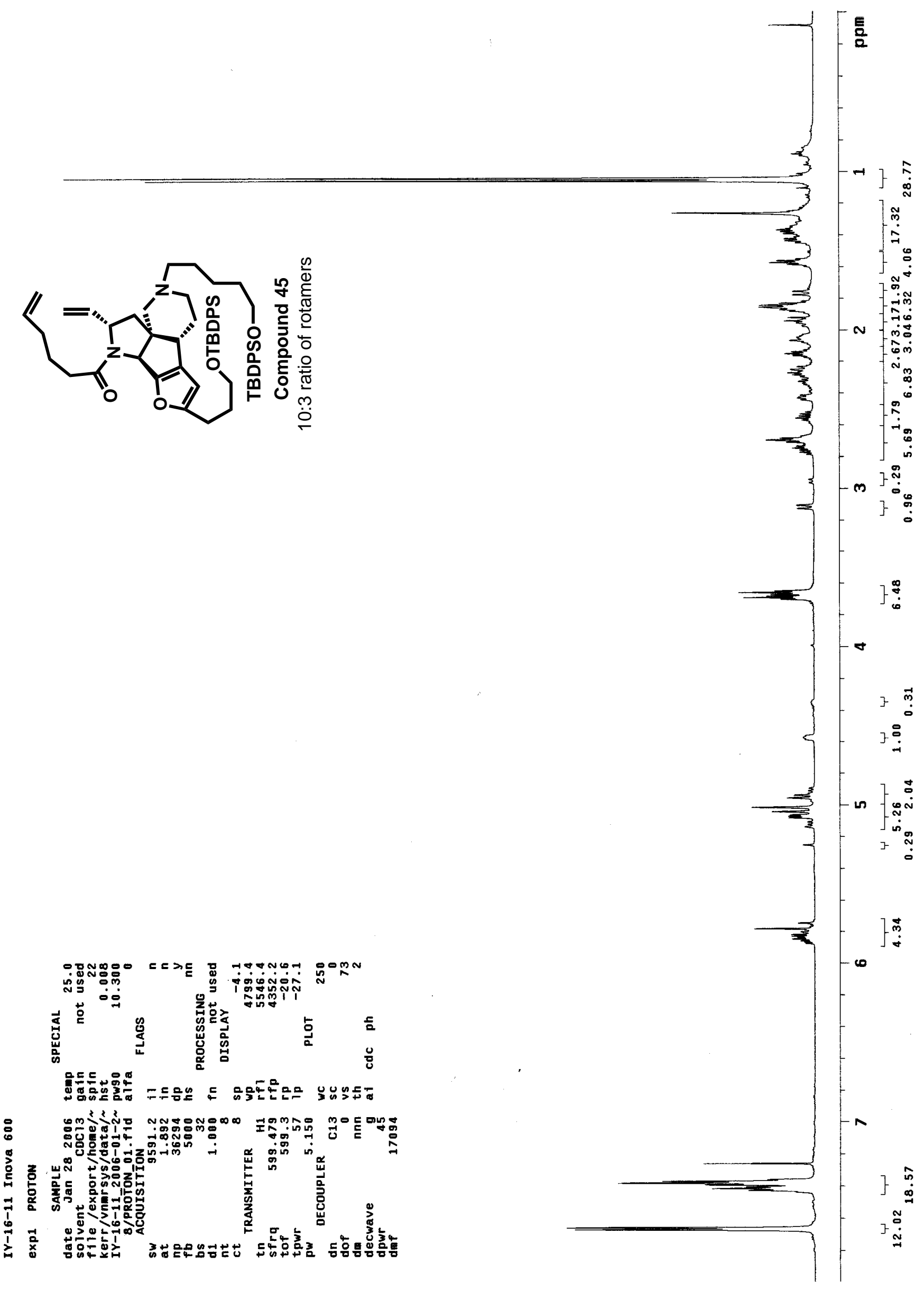




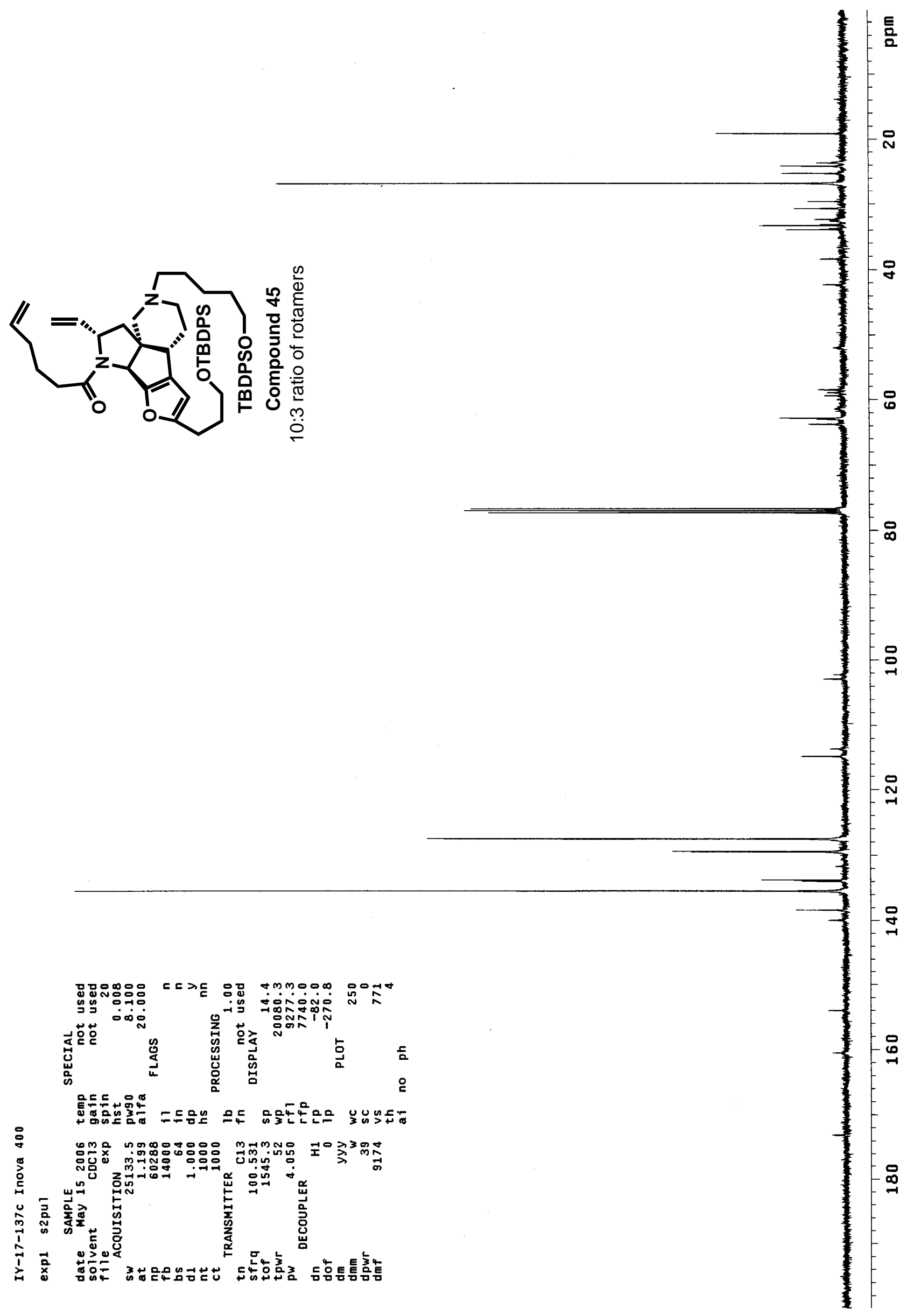




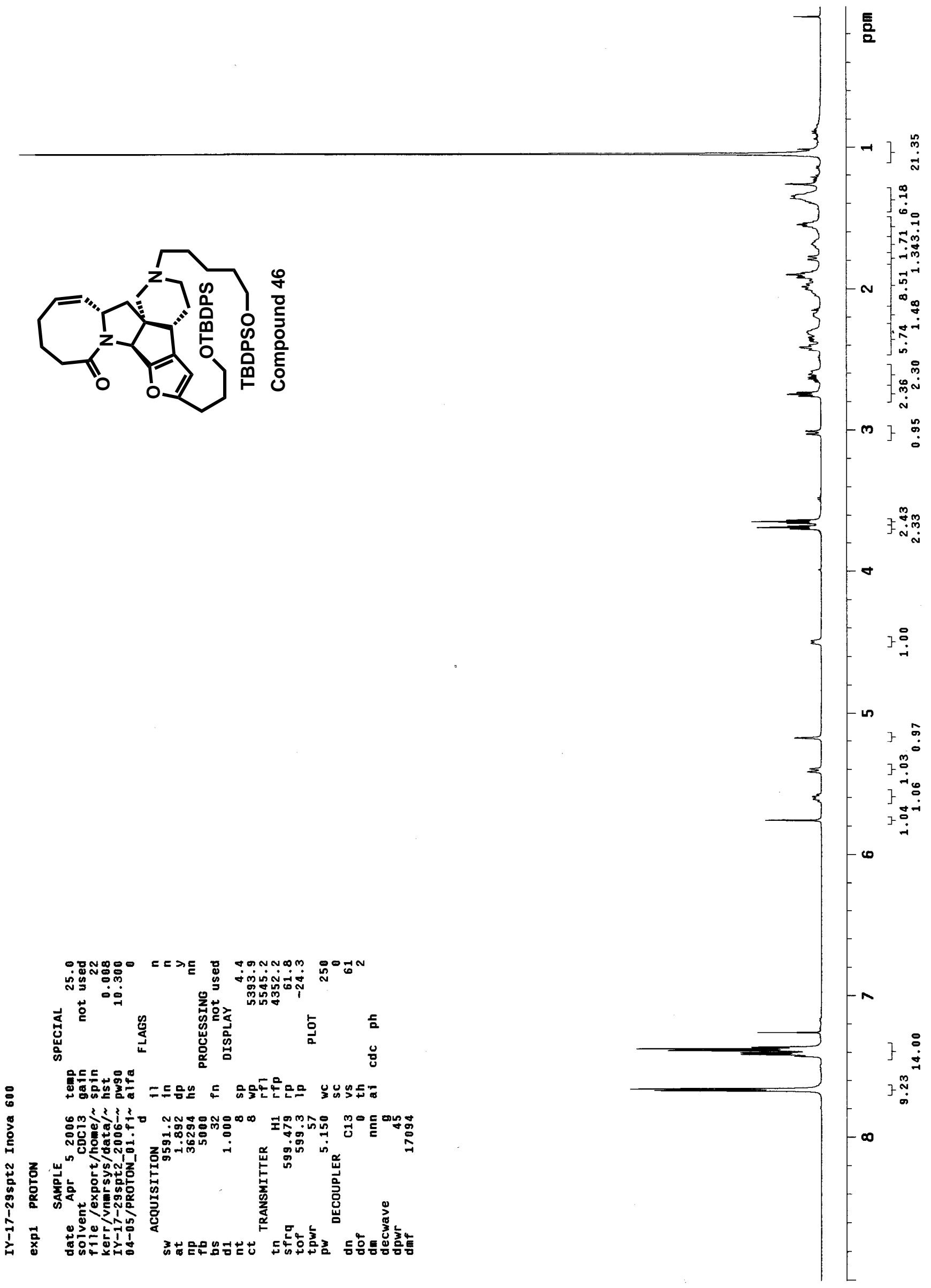



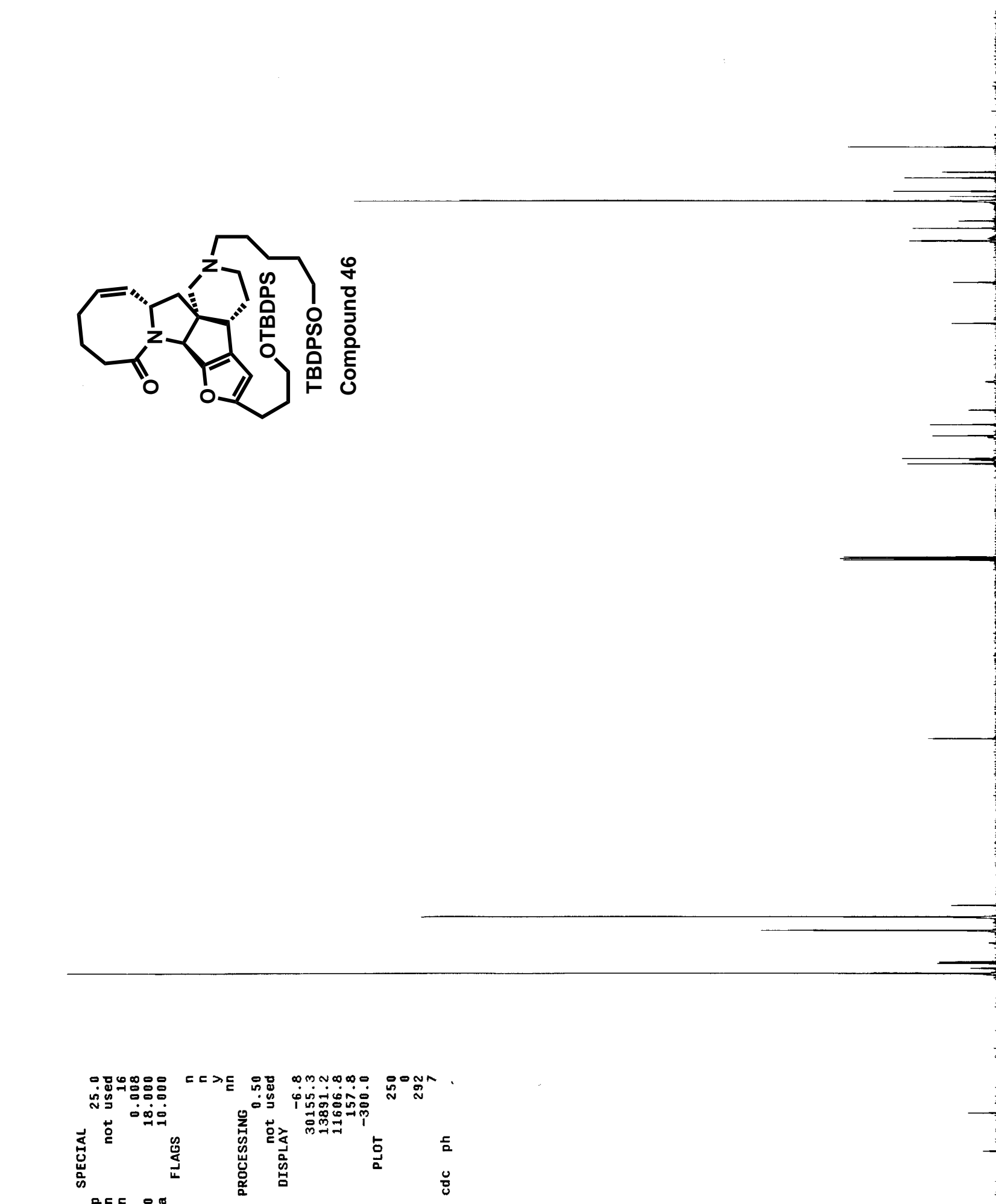

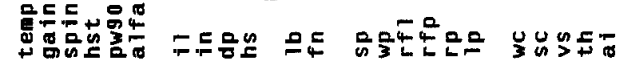

:

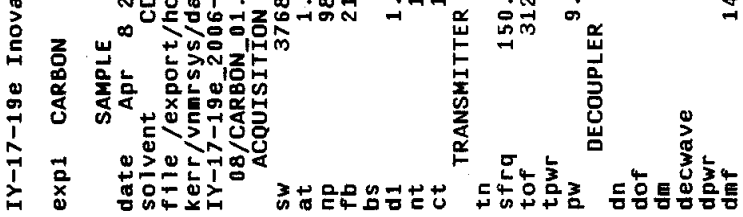




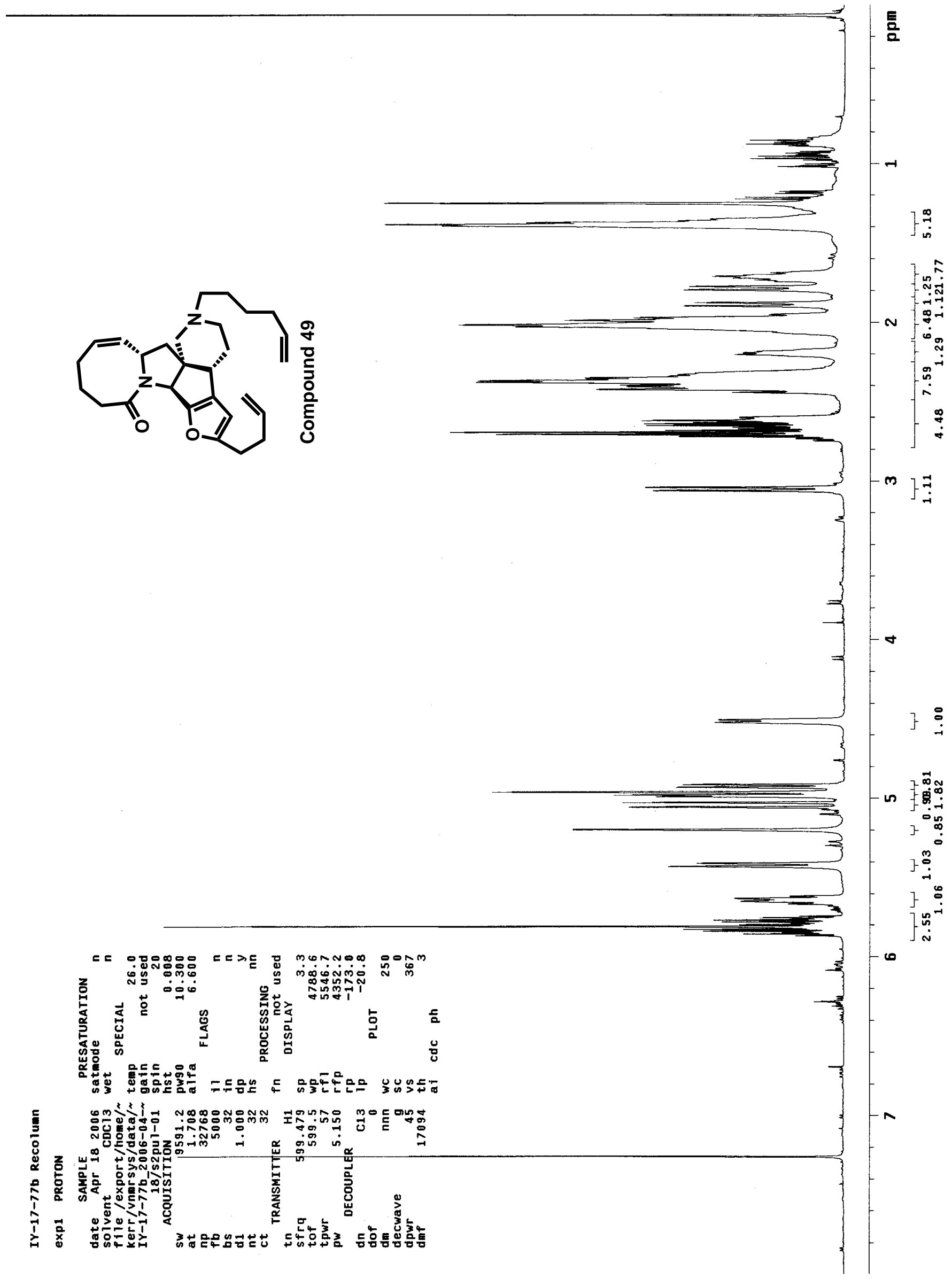




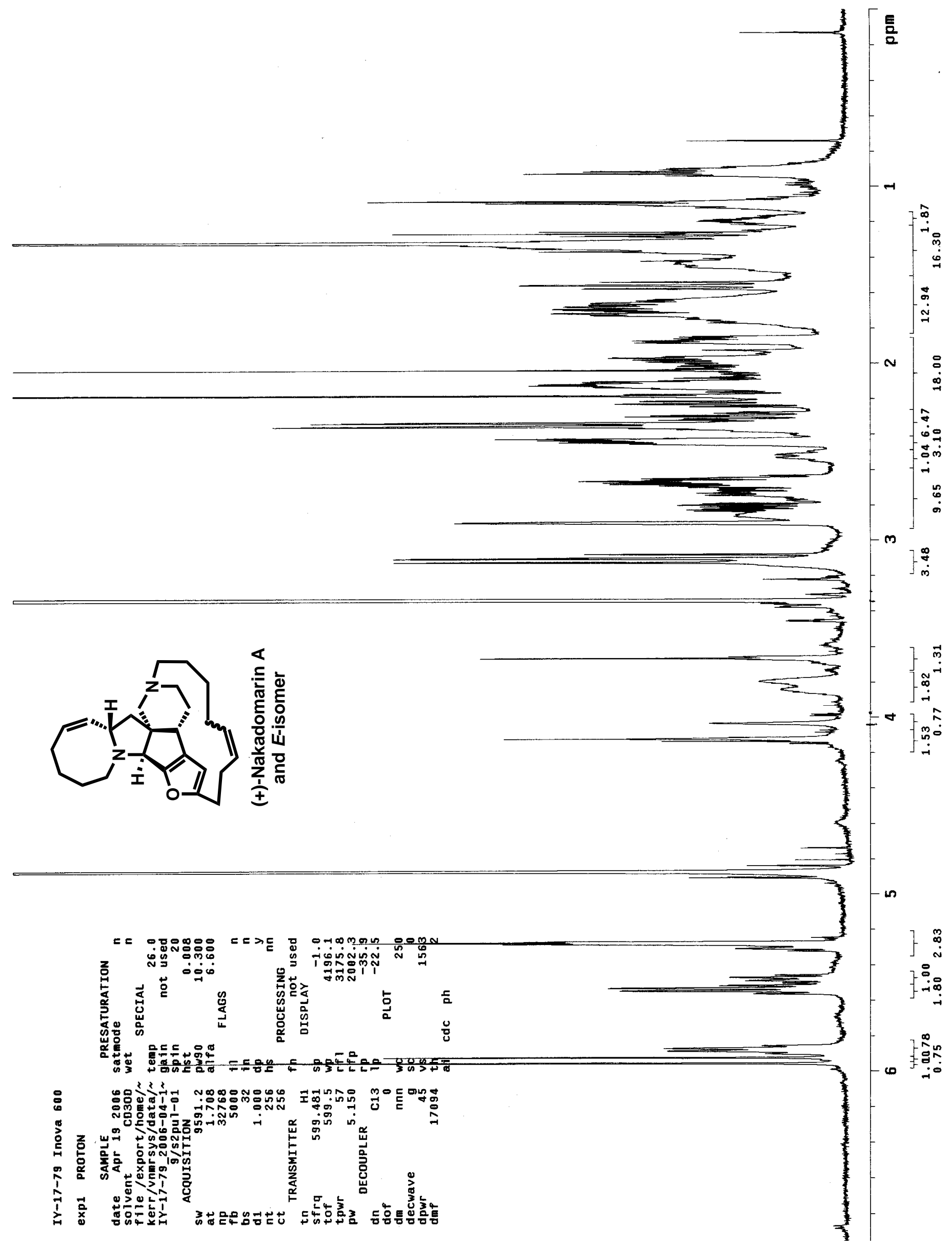




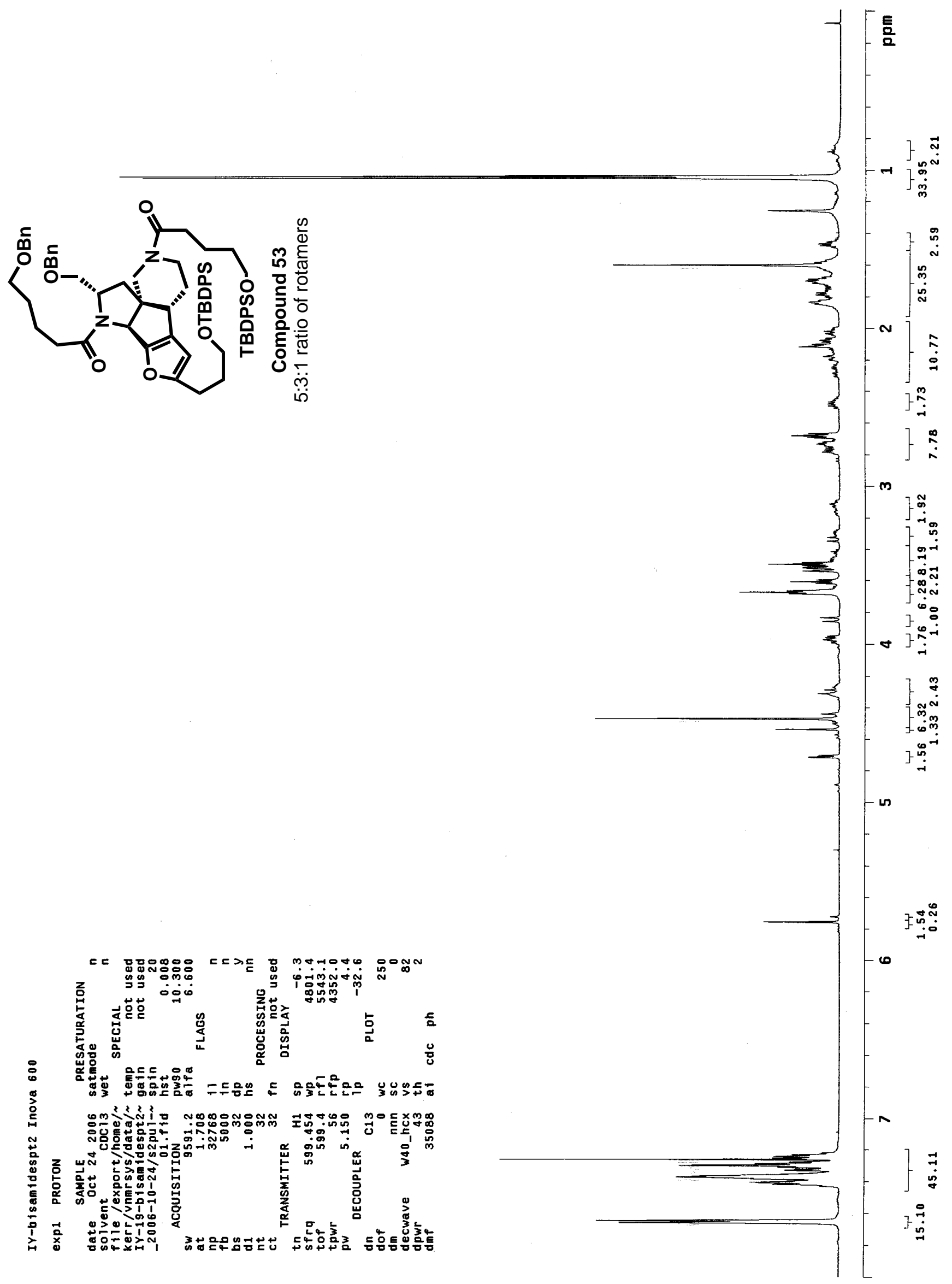




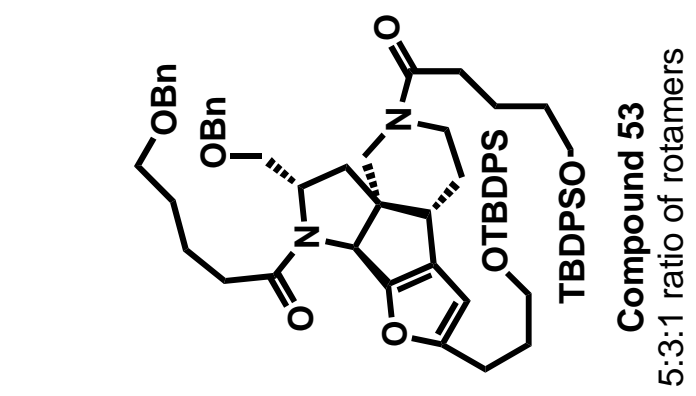

틀
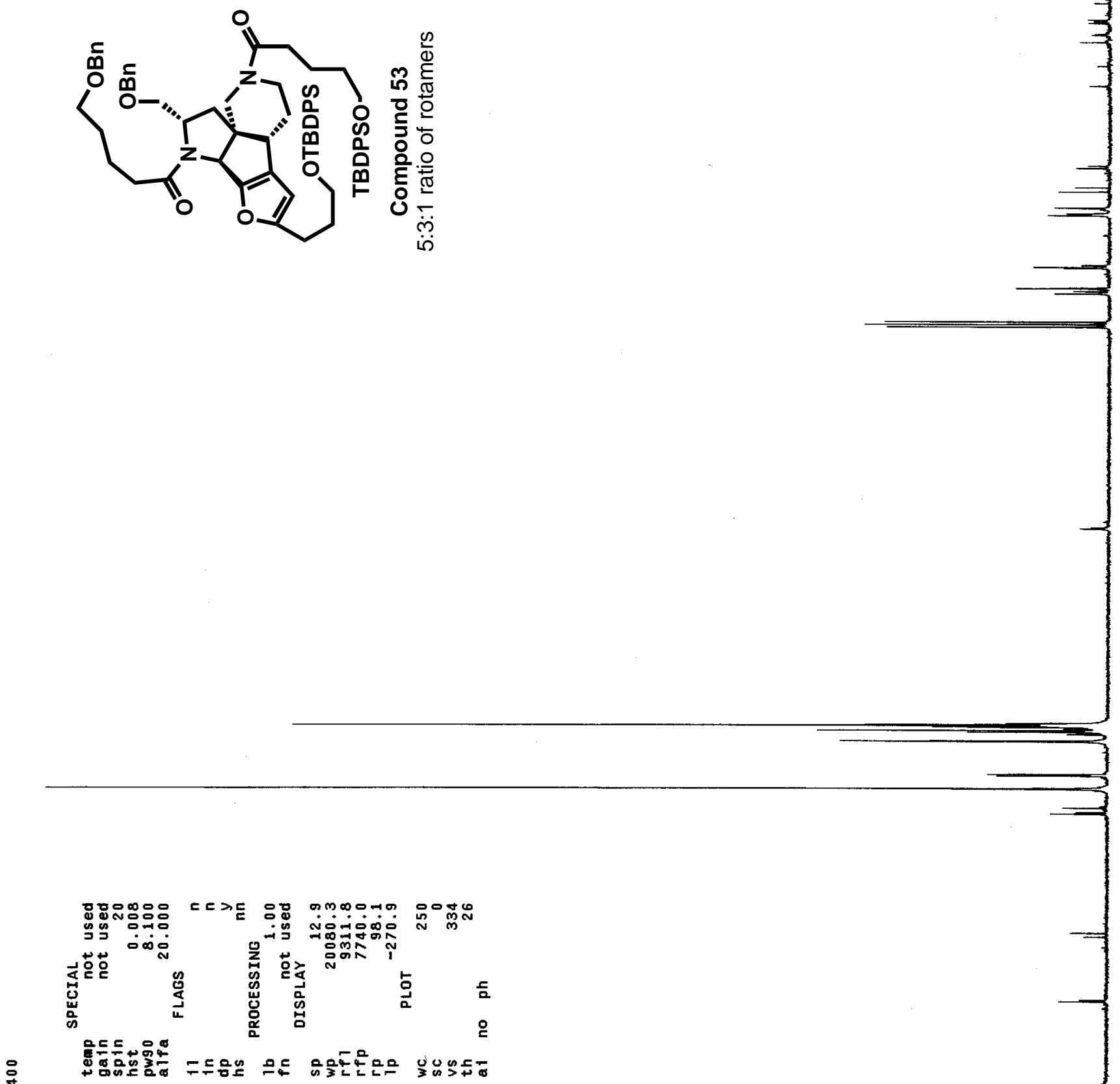

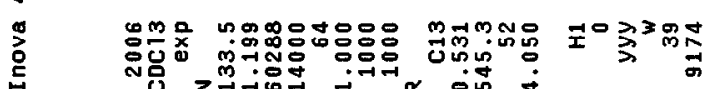

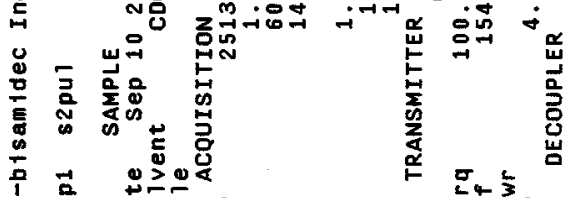

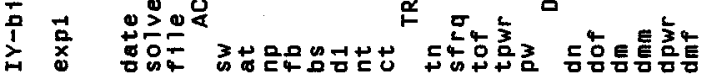




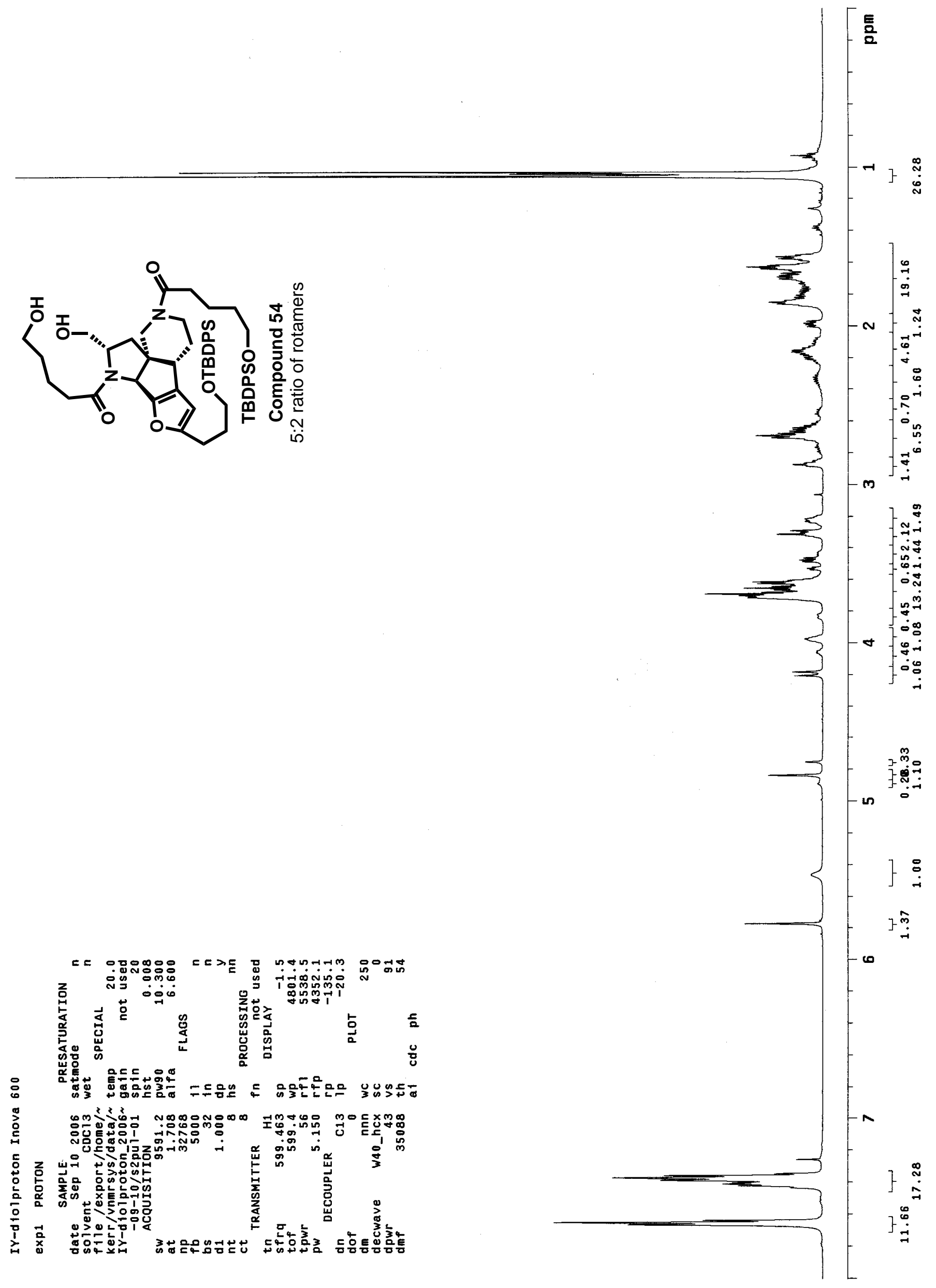




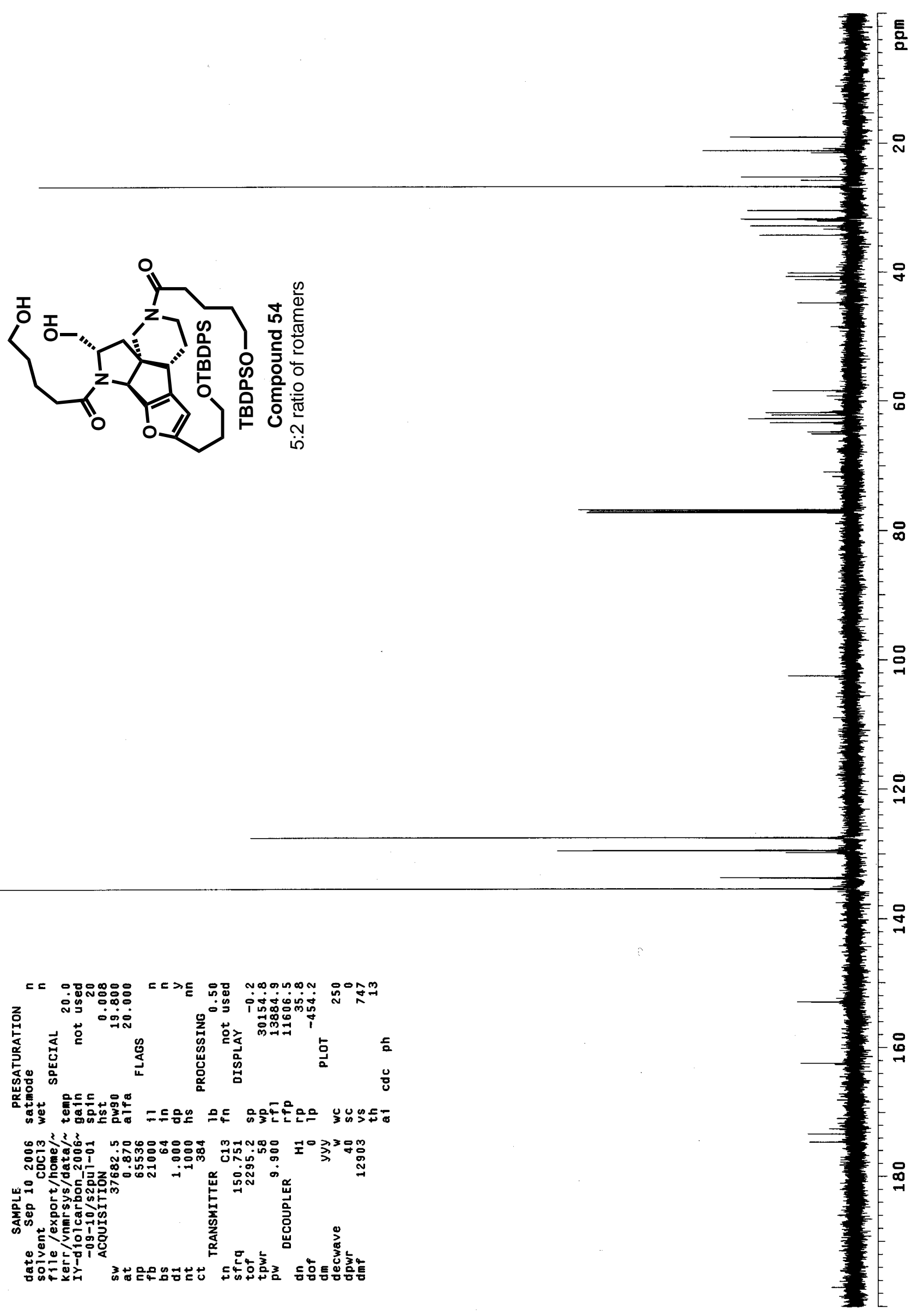




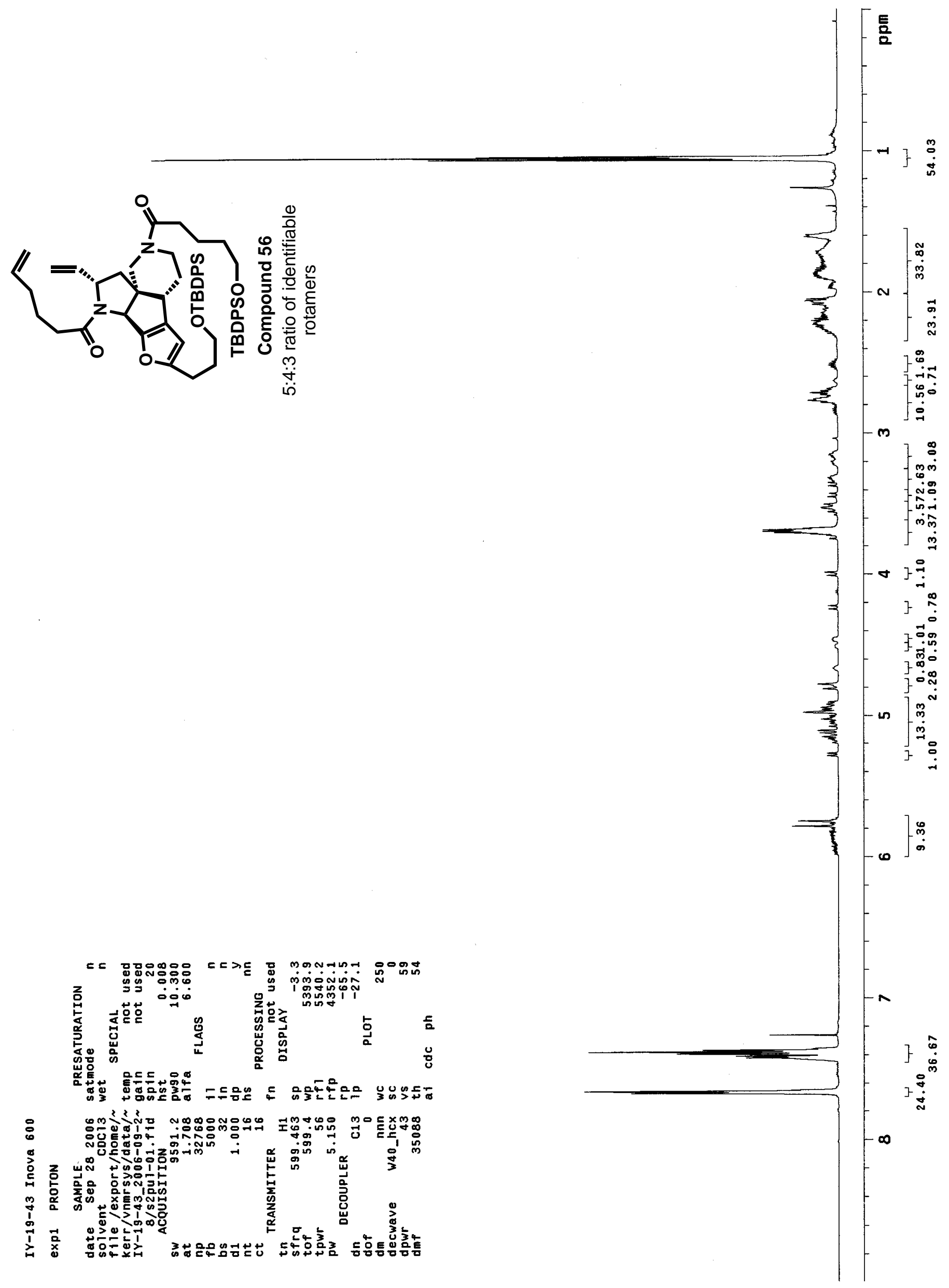




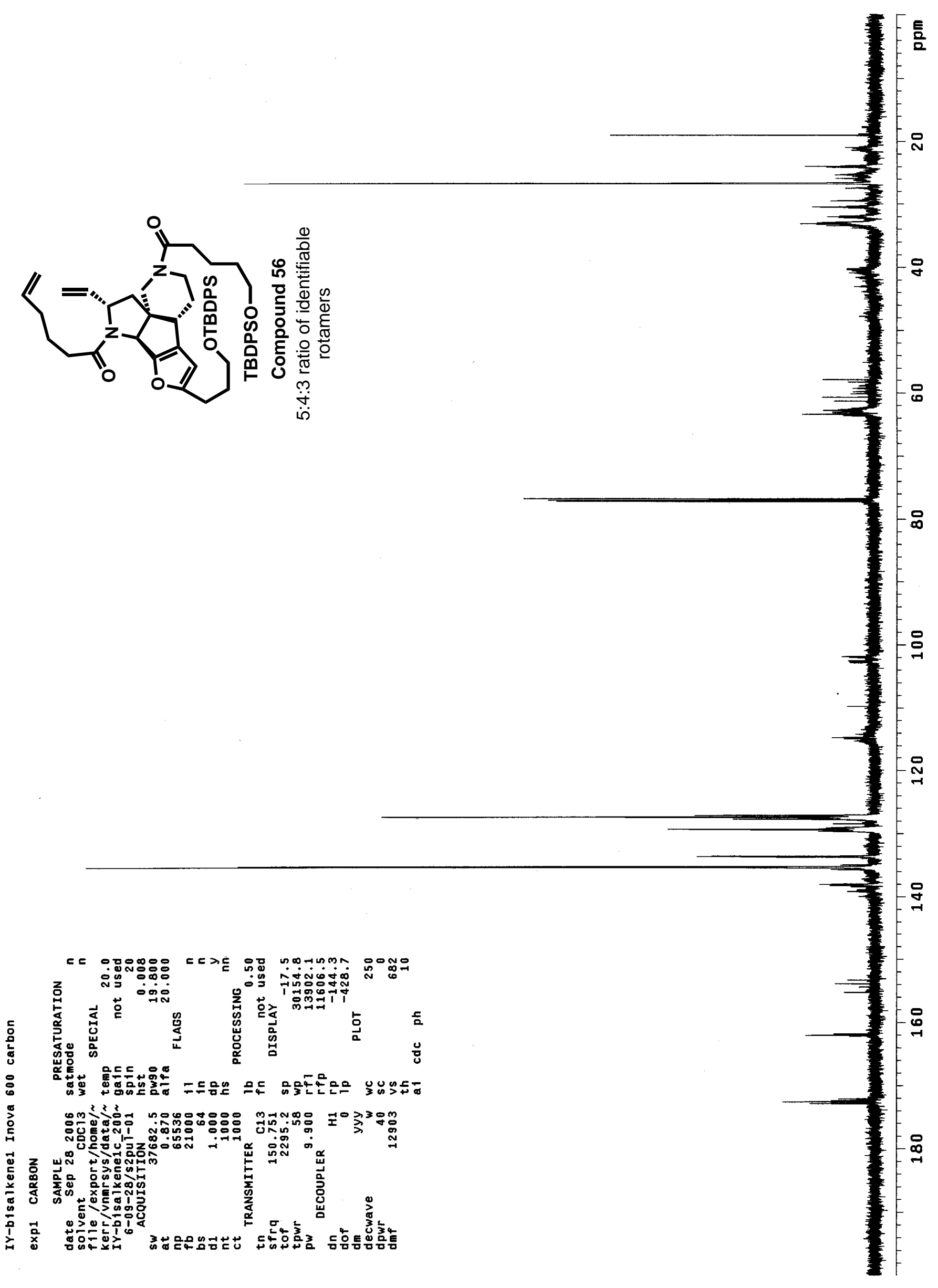




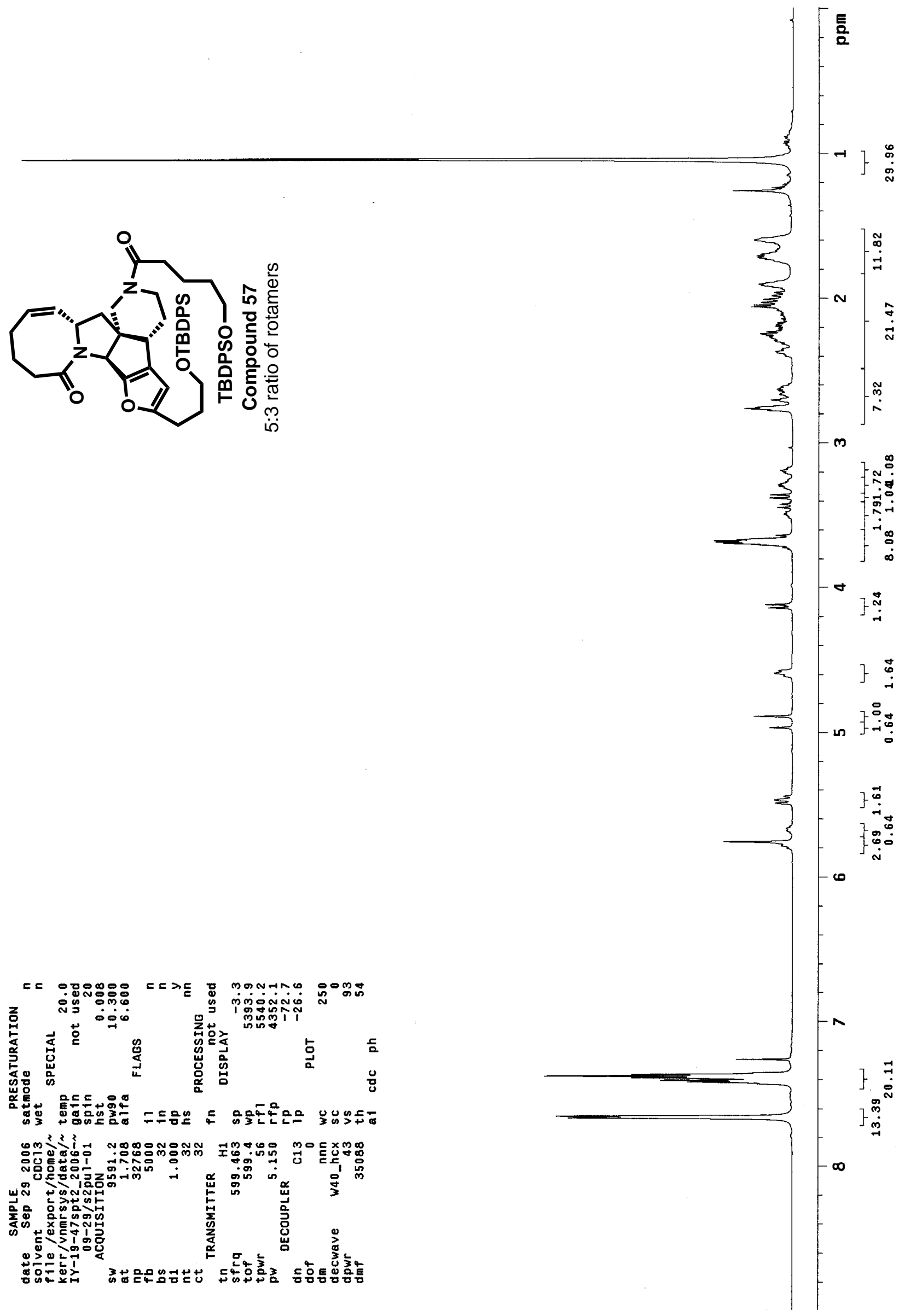



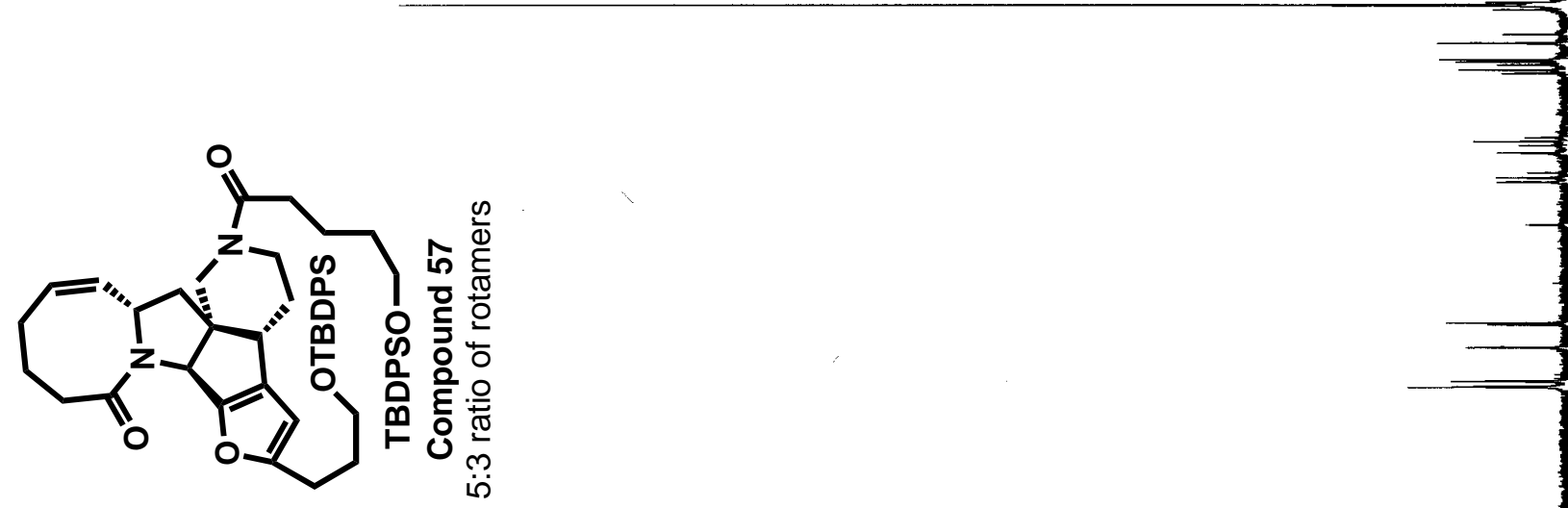

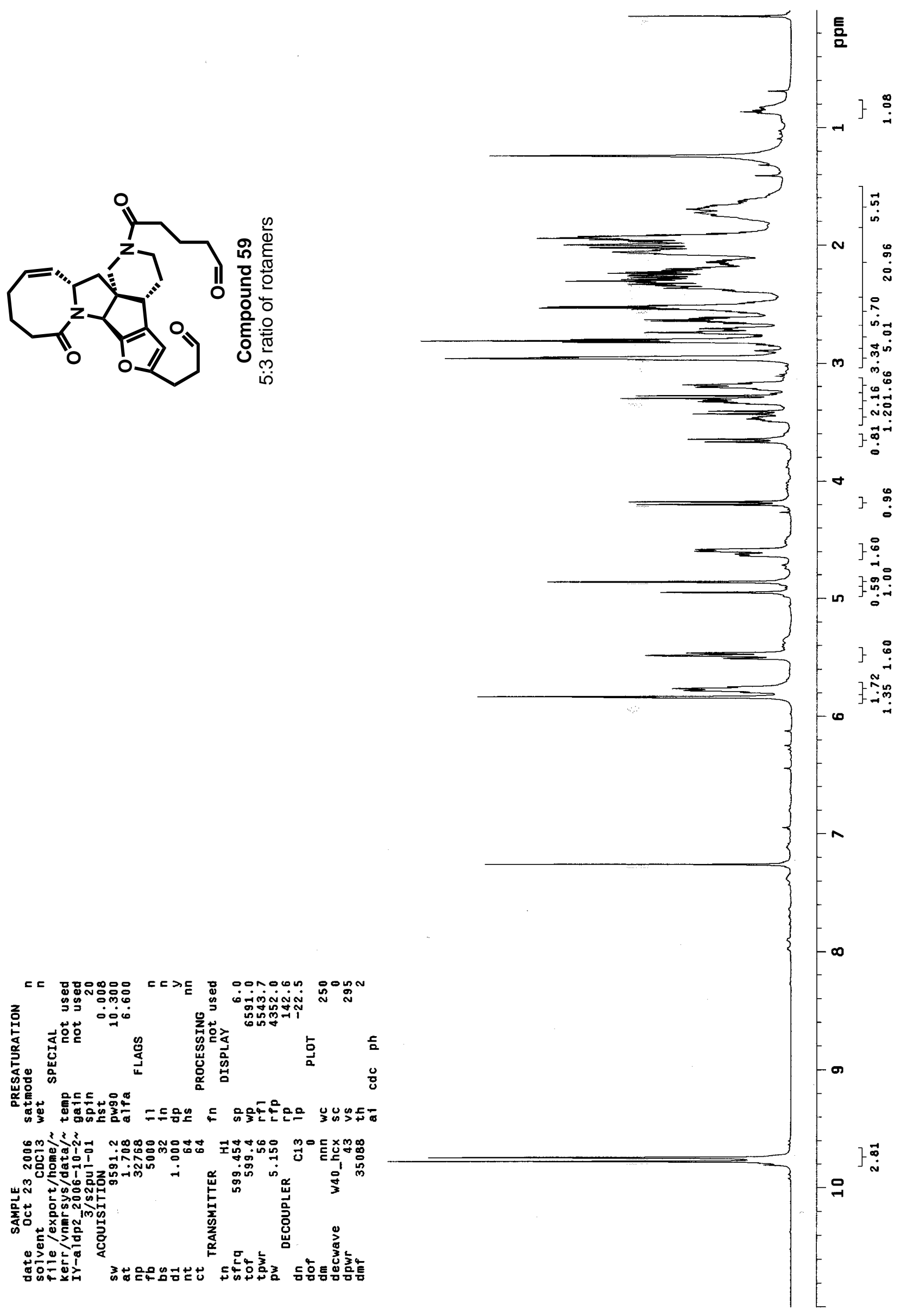

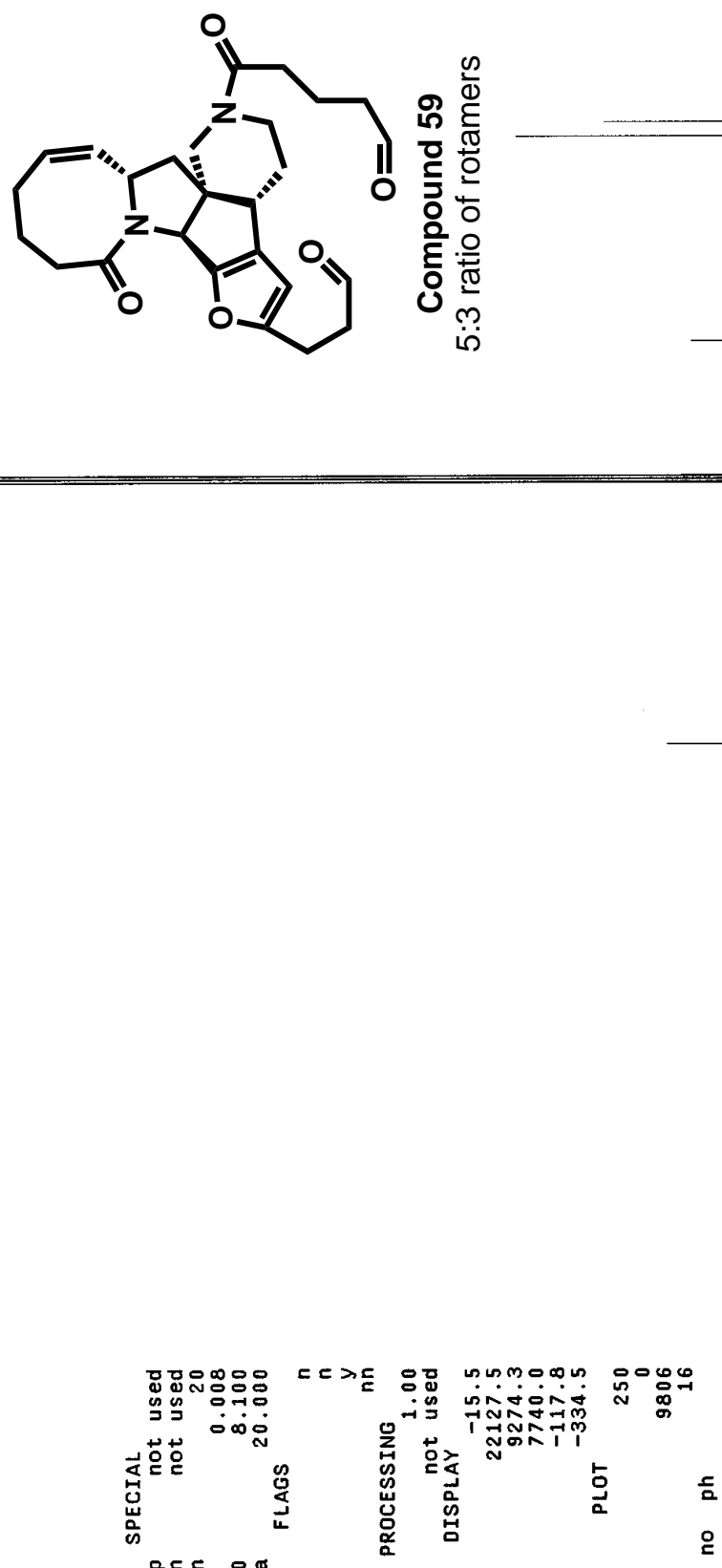

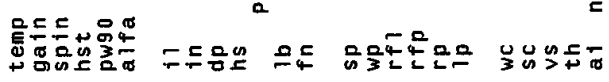

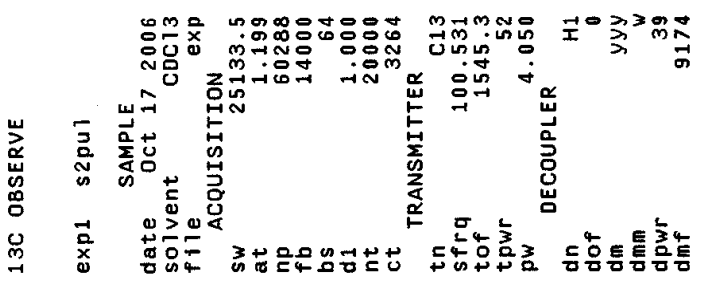




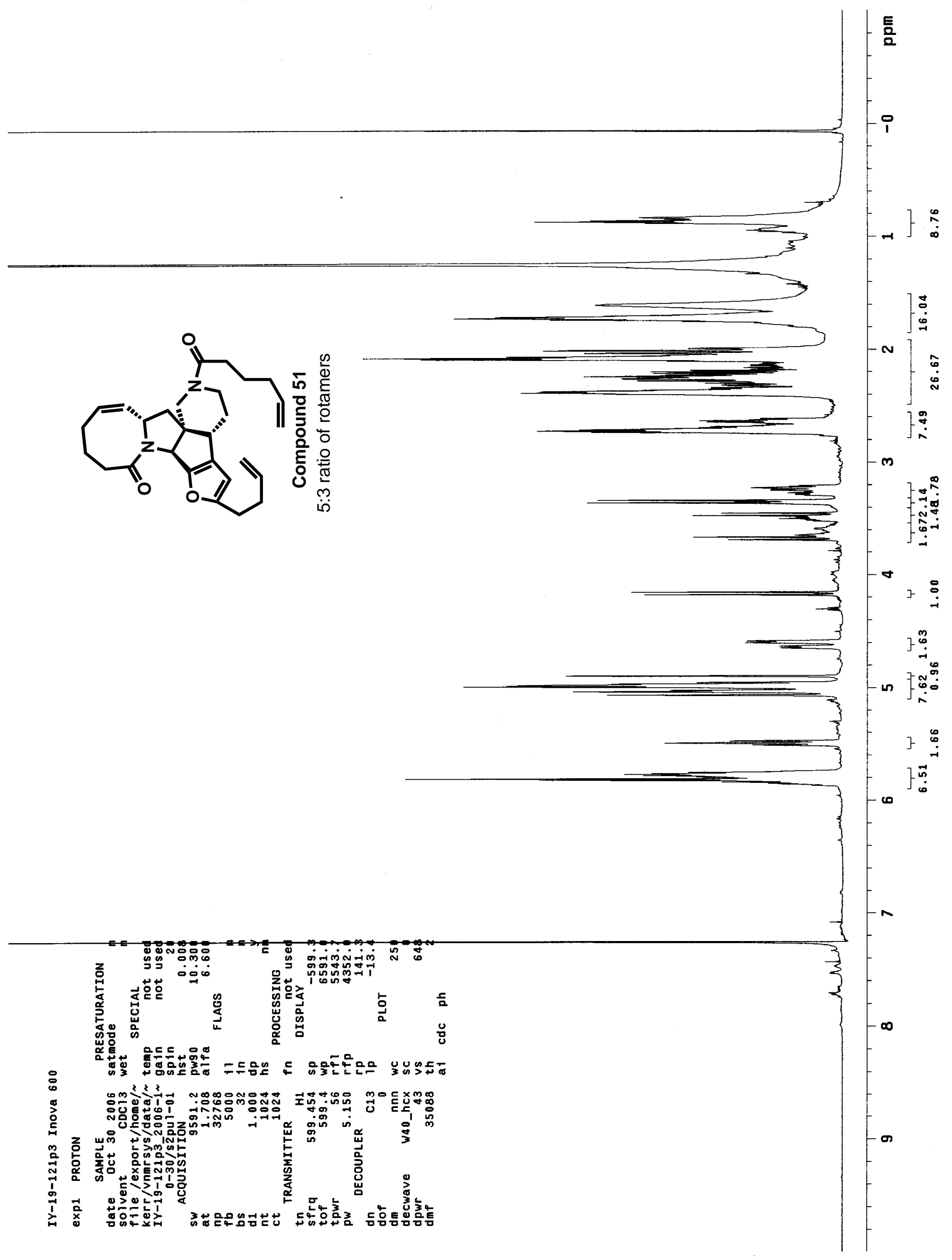




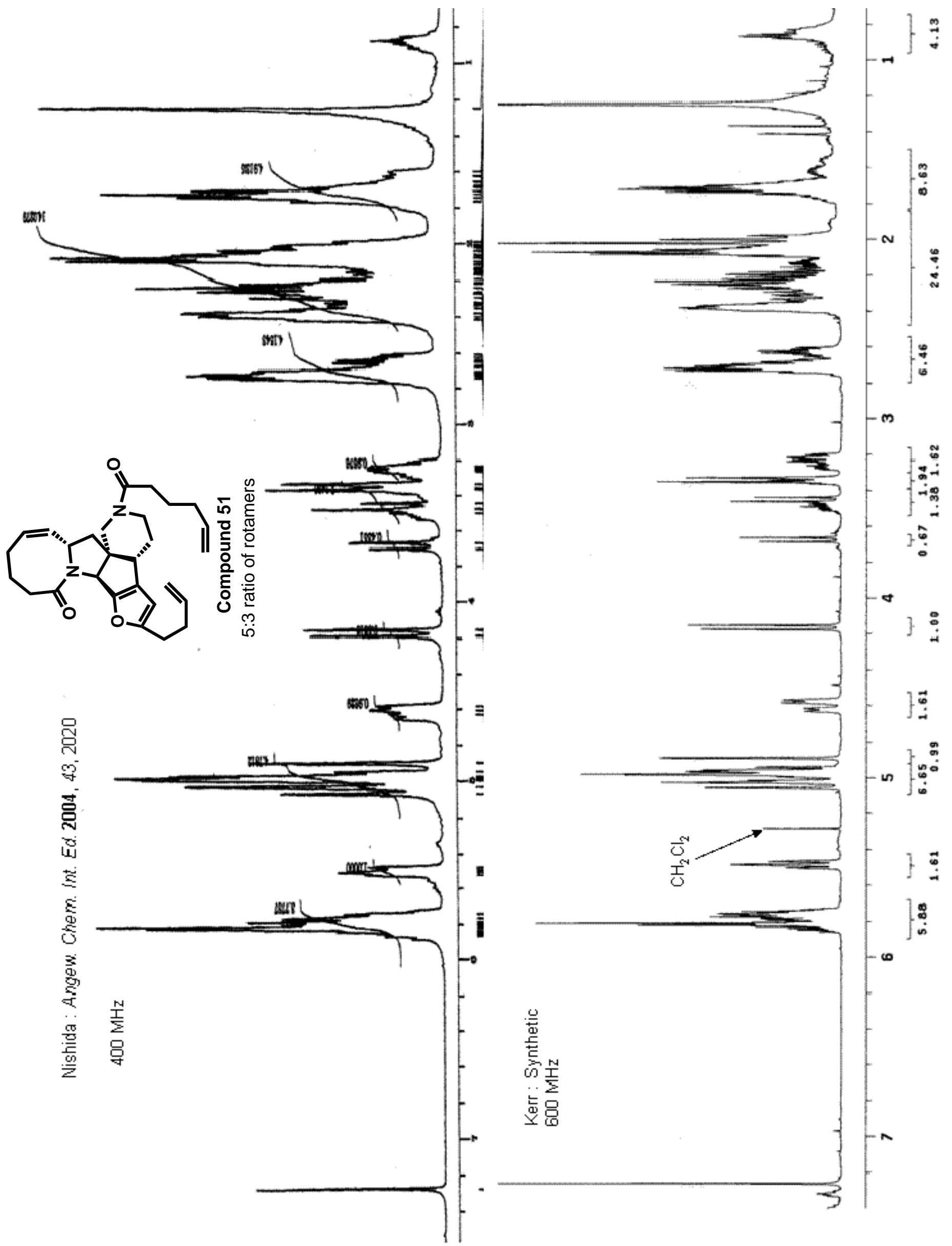




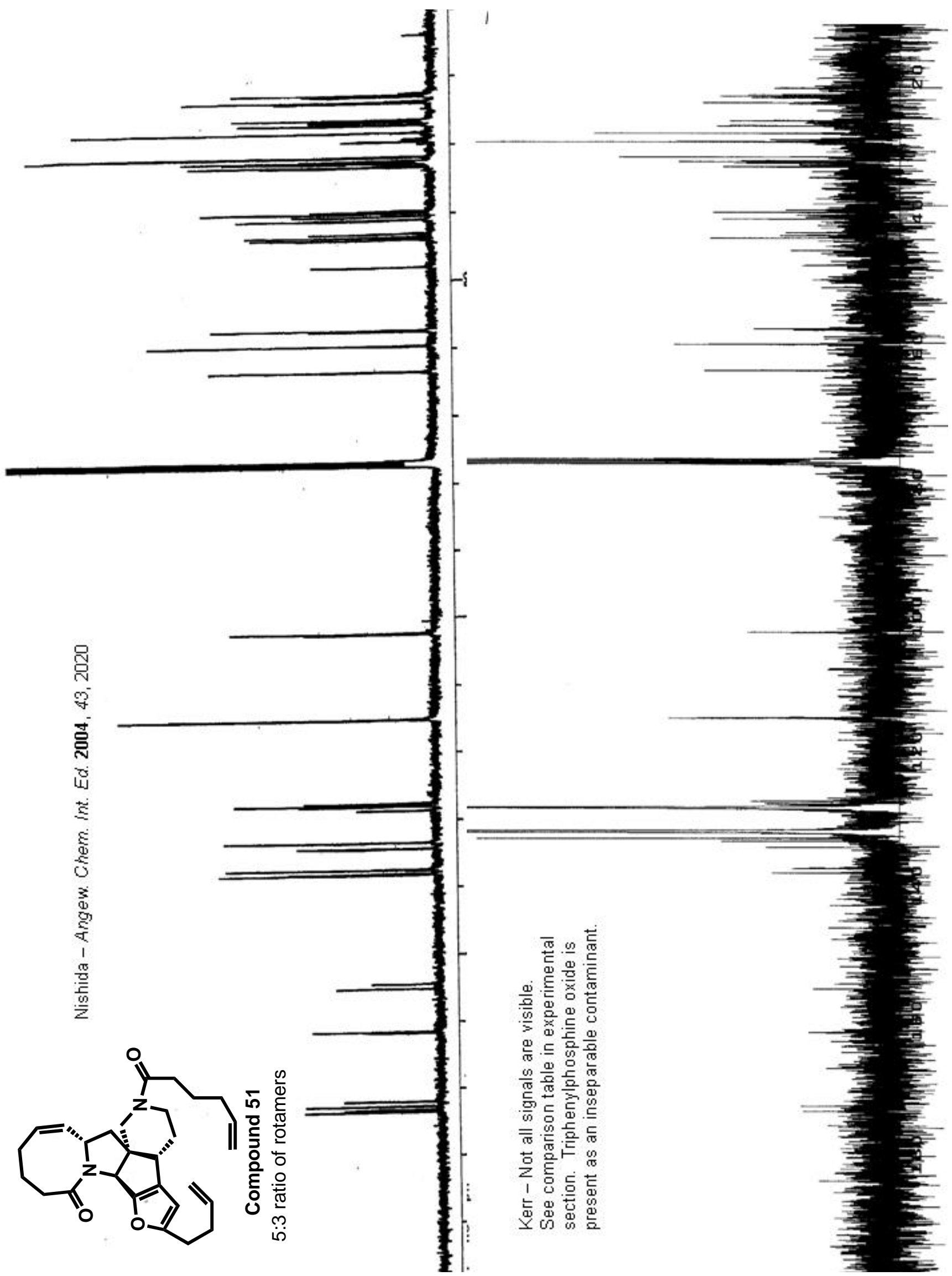




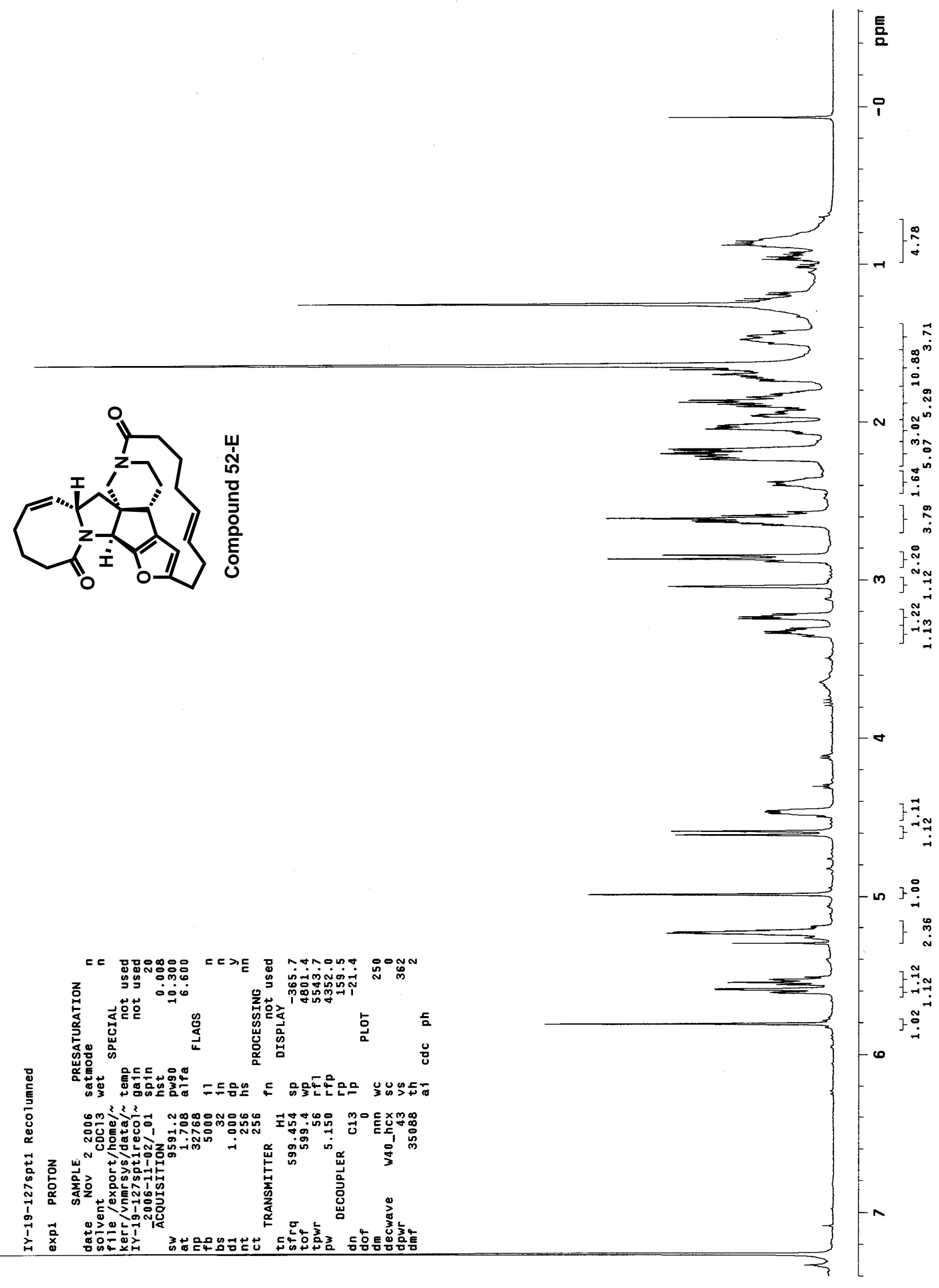




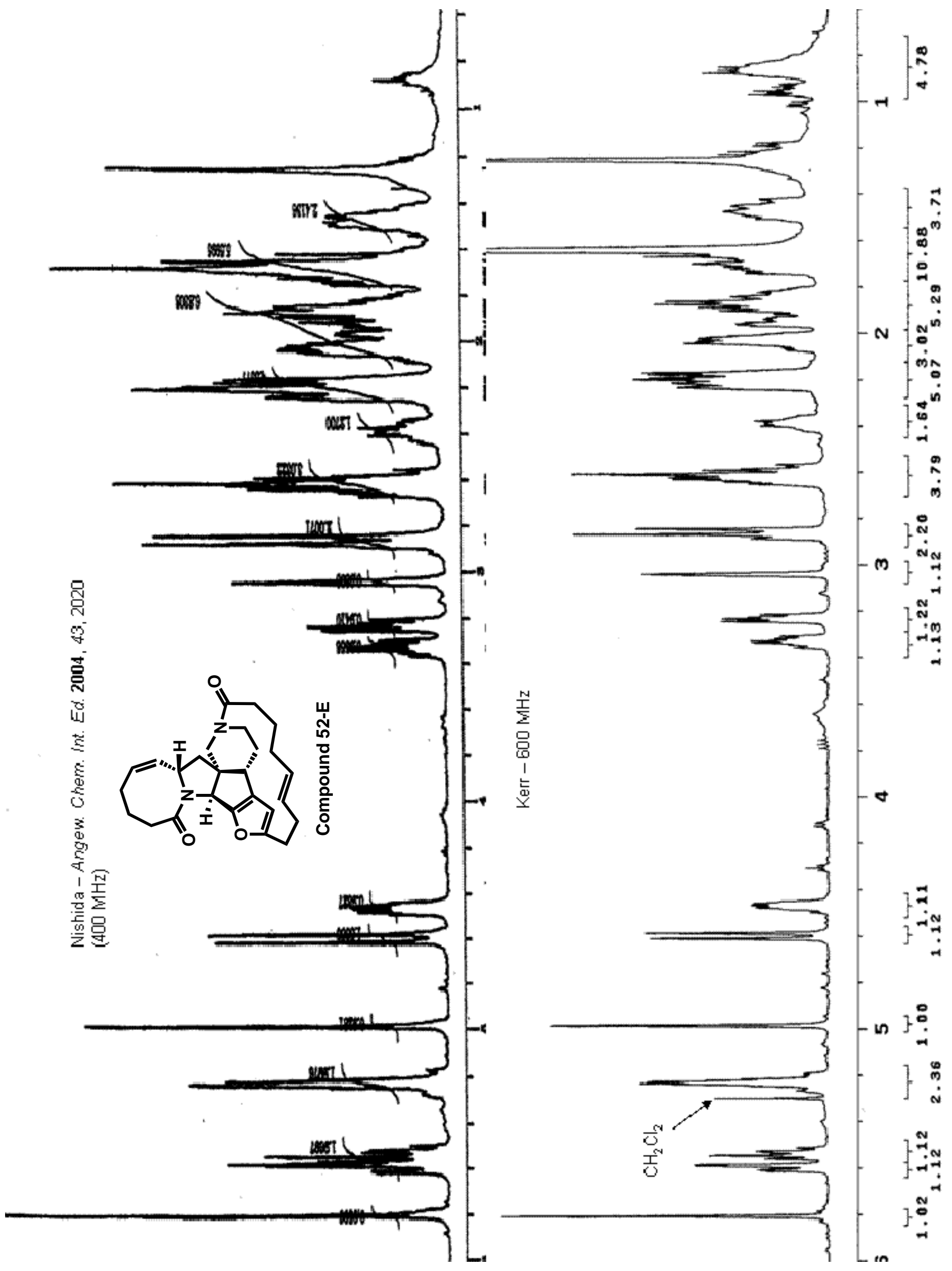




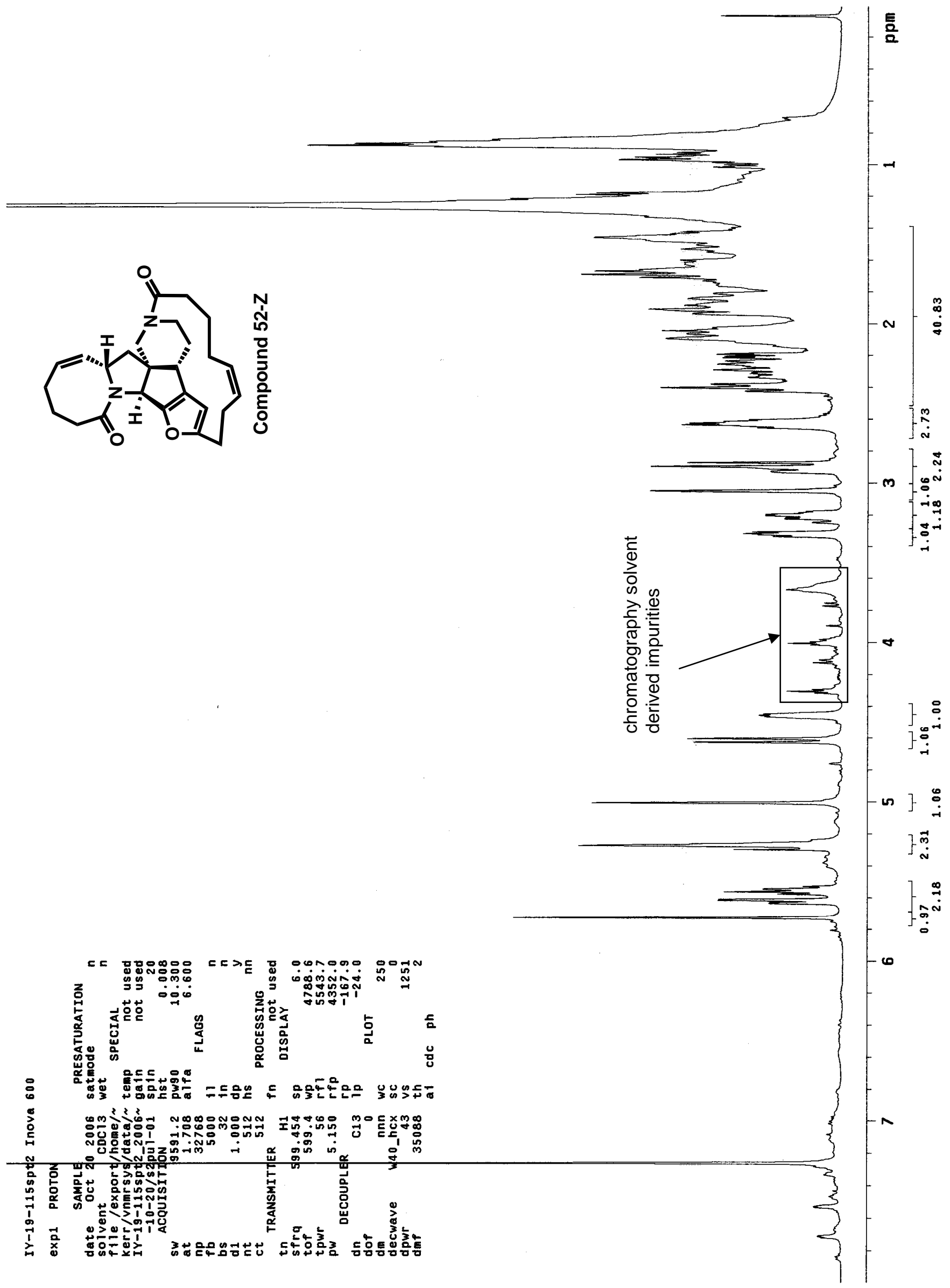




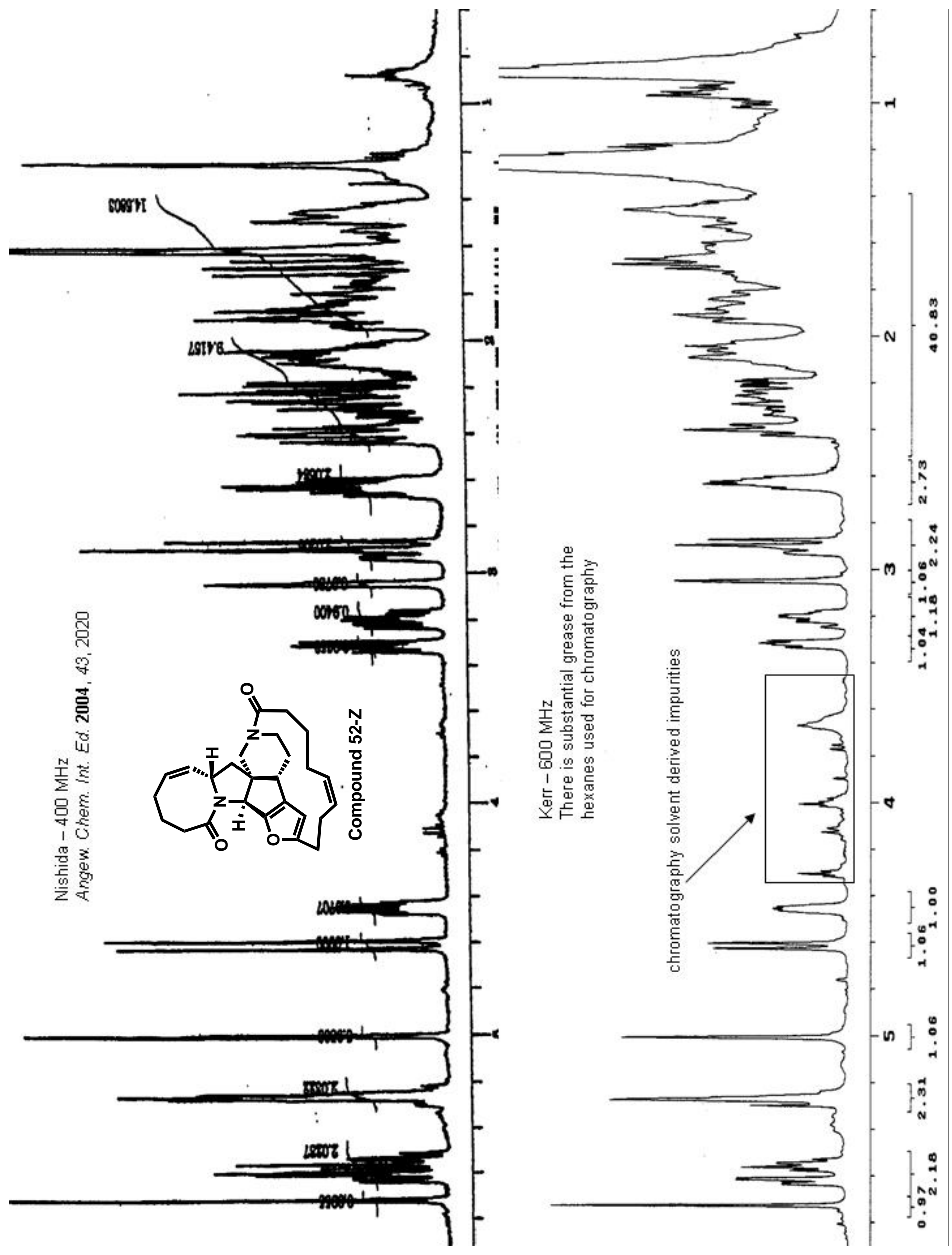




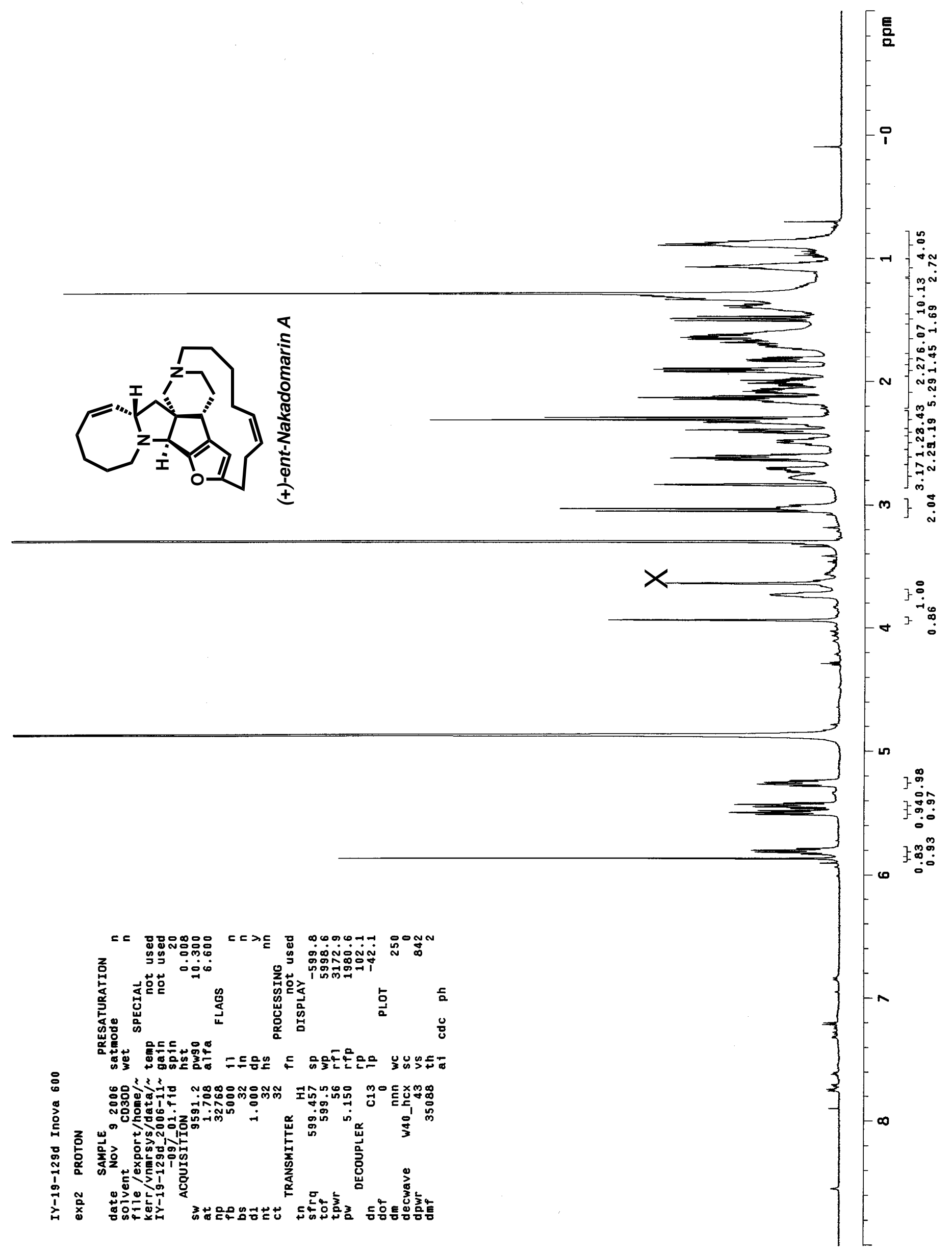




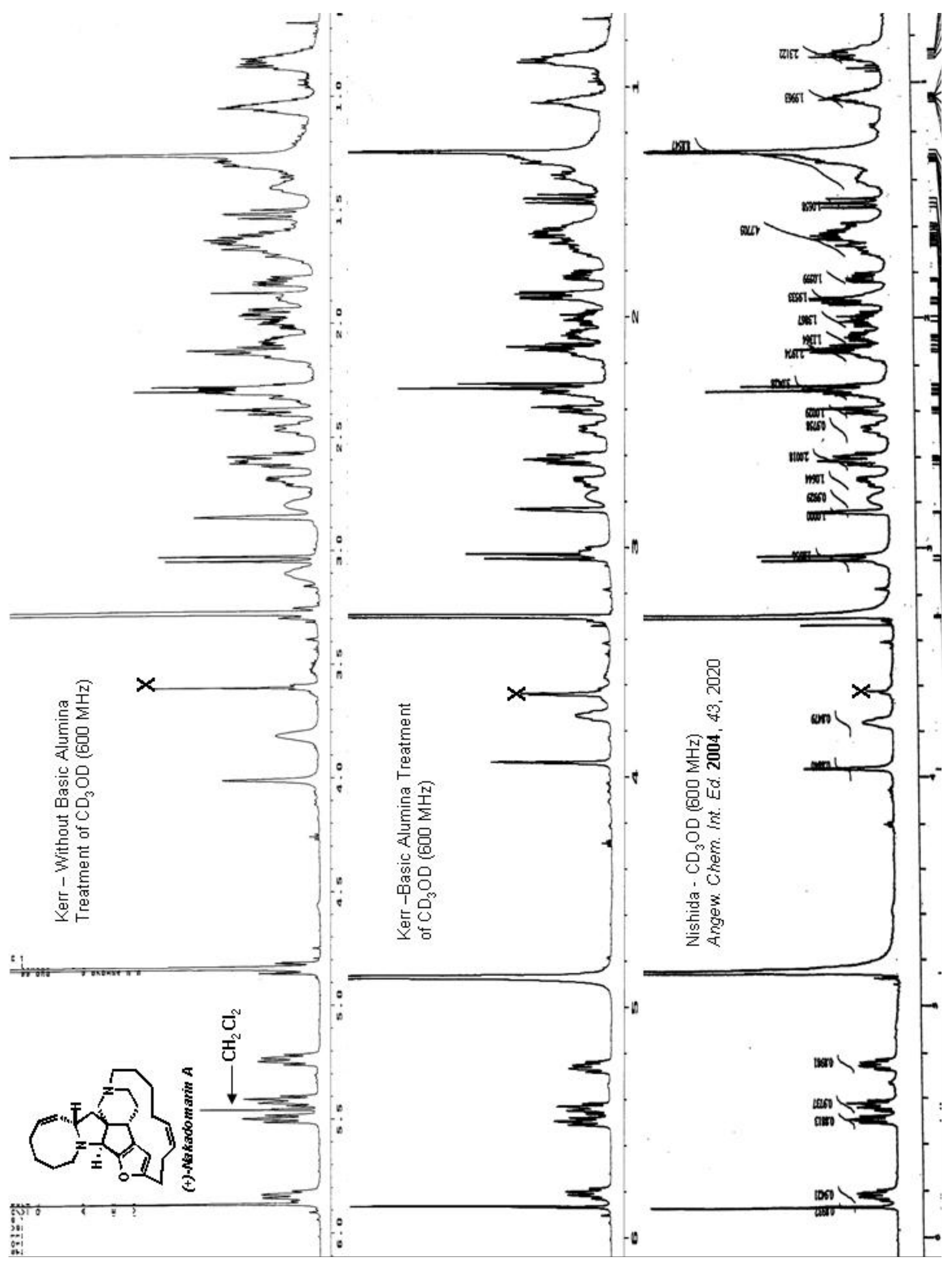

